Cochrane Database of Systematic Reviews

\title{
Oral 5-aminosalicylic acid for maintenance of remission in ulcerative colitis (Review)
}

Wang Y, Parker CE, Feagan BG, MacDonald JK

Wang Y, Parker CE, Feagan BG, MacDonald JK.

Oral 5-aminosalicylic acid for maintenance of remission in ulcerative colitis.

Cochrane Database of Systematic Reviews 2016, Issue 5. Art. No.: CD000544. DOI: 10.1002/14651858.CD000544.pub4.

www.cochranelibrary.com 
TABLE OF CONTENTS

HEADER

ABSTRACT

PLAIN LANGUAGE SUMMARY

SUMMARY OF FINDINGS

BACKGROUND

OBJECTIVES

METHODS

RESULTS

Figure 1.

Figure 2.

DISCUSSION

AUTHORS' CONCLUSIONS

ACKNOWLEDGEMENTS

REFERENCES

CHARACTERISTICS OF STUDIES

DATA AND ANALYSES

Analysis 1.1. Comparison 15-ASA versus placebo, Outcome 1 Failure to Maintain Clinical or Endoscopic Remission.

Analysis 1.2. Comparison 15-ASA versus placebo, Outcome 2 Development of Any Adverse Event.

Analysis 1.3. Comparison 15-ASA versus placebo, Outcome 3 Development of Any Adverse Event (Sensitivity analysis). .........

Analysis 1.4. Comparison 15-ASA versus placebo, Outcome 4 Withdrawal from Study due to Adverse Event. ...........................

Analysis 1.5. Comparison 1 5-ASA versus placebo, Outcome 5 Withdrawal from Study due to Adverse Event (Sensitivity analysis).

Analysis 1.6. Comparison 15-ASA versus placebo, Outcome 6 Exclusion/Withdrawal after Entry (not due to relapse). .............

Analysis 2.1. Comparison 2 5-ASA versus sulfasalazine, Outcome 1 Failure to Maintain Clinical or Endoscopic Remission. ........

Analysis 2.2. Comparison 25-ASA versus sulfasalazine, Outcome 2 Failure to Maintain Remission (trials without olsalazine). ....

Analysis 2.3. Comparison 25-ASA versus sulfasalazine, Outcome 3 Development of Any Adverse Event.

Analysis 2.4. Comparison 25-ASA versus sulfasalazine, Outcome 4 Withdrawal from Study due to Adverse Event. .................. Analysis 2.5. Comparison 2 5-ASA versus sulfasalazine, Outcome 5 Exclusion/Withdrawal after Entry (not due to relapse). ...... Analysis 3.1. Comparison 3 Once daily versus conventional dosing, Outcome 1 Failure to Maintain Clinical or Endoscopic Remission at 6 months.

Analysis 3.2. Comparison 3 Once daily versus conventional dosing, Outcome 2 Failure to Maintain Clinical or Endoscopic Remission at 12 months.

Analysis 3.3. Comparison 3 Once daily versus conventional dosing, Outcome 3 Failure to adhere to study medication regimen at study endpoint.

Analysis 3.4. Comparison 3 Once daily versus conventional dosing, Outcome 4 Failure to adhere to study medication regimen (Sensitivity analysis - excluding outliers).

Analysis 3.5. Comparison 3 Once daily versus conventional dosing, Outcome 5 Development of Any Adverse Event. ............... Analysis 3.6. Comparison 3 Once daily versus conventional dosing, Outcome 6 Withdrawal due to adverse event.

Analysis 3.7. Comparison 3 Once daily versus conventional dosing, Outcome 7 Exclusion/Withdrawal after Entry (not due to relapse).

Analysis 4.1. Comparison 4 5-ASA versus comparator 5-ASA, Outcome 1 Failure to Maintain Clinical or Endoscopic Remission at 12 months.

Analysis 4.2. Comparison 4 5-ASA versus comparator 5-ASA, Outcome 2 Development of Any Adverse Event.

Analysis 4.3. Comparison 45-ASA versus comparator 5-ASA, Outcome 3 Withdrawal from Study due to Adverse Event. ........... Analysis 4.4. Comparison 45-ASA versus comparator 5-ASA, Outcome 4 Exclusion/Withdrawal after Entry (not due to relapse). . Analysis 5.1. Comparison 5 5-ASA (dose ranging), Outcome 1 Failure to Maintain Clinical or Endoscopic Remission.

Analysis 5.2. Comparison 5 5-ASA (dose ranging), Outcome 2 Development of Any Adverse Event.

Analysis 5.3. Comparison 5 5-ASA (dose ranging), Outcome 3 Withdrawal from Study due to Adverse Event. 
[Intervention Review]

\section{Oral 5-aminosalicylic acid for maintenance of remission in ulcerative colitis}

Yongjun Wang1, Claire E Parker², Brian G Feagan²,3,4, John K MacDonald2,3

1Schulich School of Medicine \& Dentistry, University of Western Ontario, London, Canada. ${ }^{2}$ Cochrane IBD Group, Robarts Clinical Trials, London, Canada. ${ }^{3}$ Department of Medicine, University of Western Ontario, London, Canada. ${ }^{4}$ Department of Epidemiology and Biostatistics, University of Western Ontario, London, Canada

Contact address: John K MacDonald, Cochrane IBD Group, Robarts Clinical Trials, 100 Dundas Street, Suite 200, London, ON, N6A 5B6, Canada.john.macdonald@robartsinc.com,jmacdon1@uwo.ca.

Editorial group: Cochrane IBD Group

Publication status and date: New search for studies and content updated (no change to conclusions), published in Issue 5, 2016.

Citation: Wang Y, Parker CE, Feagan BG, MacDonald JK. Oral 5-aminosalicylic acid for maintenance of remission in ulcerative colitis. Cochrane Database of Systematic Reviews 2016, Issue 5. Art. No.: CD000544. DOI: 10.1002/14651858.CD000544.pub4.

Copyright @ 2016 The Cochrane Collaboration. Published by John Wiley \& Sons, Ltd.

\section{A B S T R A C T}

\section{Background}

Oral 5-aminosalicylic (5-ASA) preparations were intended to avoid the adverse effects of sulfasalazine (SASP) while maintaining its therapeutic benefits. Previously, it was found that 5-ASA drugs were more effective than placebo but had a statistically significant therapeutic inferiority relative to SASP. This updated review includes more recent studies and evaluates the effectiveness, doseresponsiveness, and safety of 5-ASA preparations used for maintenance of remission in quiescent ulcerative colitis.

\section{Objectives}

The primary objectives were to assess the efficacy, dose-responsiveness and safety of oral 5-ASA compared to placebo, SASP, or 5-ASA comparators for maintenance of remission in quiescent ulcerative colitis. A secondary objective was to compare the efficacy and safety of once daily dosing of oral 5-ASA with conventional (two or three times daily) dosing regimens.

\section{Search methods}

A literature search for relevant studies (inception to 9 July 2015) was performed using MEDLINE, EMBASE and the Cochrane Library. Review articles and conference proceedings were also searched to identify additional studies.

\section{Selection criteria}

Studies were accepted for analysis if they were randomized controlled trials with a minimum treatment duration of six months. Studies of oral 5-ASA therapy for treatment of patients with quiescent ulcerative colitis compared with placebo, SASP or other 5-ASA formulations were considered for inclusion. Studies that compared once daily 5-ASA treatment with conventional dosing of 5-ASA and 5-ASA dose ranging studies were also considered for inclusion.

\section{Data collection and analysis}

The primary outcome was the failure to maintain clinical or endoscopic remission. Secondary outcomes included adherence, adverse events, withdrawals due to adverse events, and withdrawals or exclusions after entry. Trials were separated into five comparison groups: 5ASA versus placebo, 5-ASA versus sulfasalazine, once daily dosing versus conventional dosing, 5-ASA versus comparator 5-ASA formulation, and 5-ASA dose-ranging. Placebo-controlled trials were subgrouped by dosage. Once daily versus conventional dosing studies were subgrouped by formulation. 5-ASA-controlled trials were subgrouped by common 5-ASA comparators (e.g. Asacol and Salofalk). Doseranging studies were subgrouped by 5-ASA formulation. We calculated the risk ratio (RR) and $95 \%$ confidence intervals ( $95 \% \mathrm{Cl}$ ) for each outcome. Data were analyzed on an intention-to-treat basis. 


\section{Main results}

Forty-one studies (8928 patients) were included. The majority of included studies were rated as low risk of bias. Ten studies were rated at high risk of bias. Seven of these studies were single-blind and three studies were open-label. However, two open-label studies and four of the single-blind studies utilized investigator performed endoscopy as an endpoint, which may protect against bias. 5-ASA was significantly superior to placebo for maintenance of clinical or endoscopic remission. Forty-one per cent of 5-ASA patients relapsed compared to $58 \%$ of placebo patients ( 7 studies, 1298 patients; RR $0.69,95 \% \mathrm{Cl} 0.62$ to 0.77 ). There was a trend towards greater efficacy with higher doses of 5-ASA with a statistically significant benefit for the 1 to $1.9 \mathrm{~g} /$ day (RR $0.65 ; 95 \% \mathrm{Cl} 0.56$ to 0.76 ) and the $\geq 2 \mathrm{~g} /$ day subgroups (RR $0.73,95 \% \mathrm{Cl} 0.60$ to 0.89 ). SASP was significantly superior to 5-ASA for maintenance of remission. Forty-eight per cent of 5-ASA patients relapsed compared to $43 \%$ of SASP patients (12 studies, 1655 patients; RR 1.14, 95\% Cl 1.03 to 1.27 ). A GRADE analysis indicated that the overall quality of the evidence for the primary outcome for the placebo and SASP-controlled studies was high. No statistically significant differences in efficacy or adherence were found between once daily and conventionally dosed 5-ASA. Twenty-nine per cent of once daily patients relapsed over 12 months compared to $31 \%$ of conventionally dosed patients ( 8 studies, 3127 patients; RR $0.91,95 \%$ Cl 0.82 to 1.01). Eleven per cent of patients in the once daily group failed to adhere to their medication regimen compared to $9 \%$ of patients in the conventional dosing group ( 6 studies, 1462 patients; RR 1.22, $95 \% \mathrm{Cl} 0.91$ to 1.64). There does not appear to be any difference in efficacy among the various 5-ASA formulations. Forty-four per cent of patients in the 5-ASA group relapsed compared to $41 \%$ of patients in the 5-ASA comparator group ( 6 studies, 707 patients; RR $1.08,95 \% \mathrm{Cl} 0.91$ to 1.28 ). A pooled analysis of two studies showed no statistically significant difference in efficacy between Balsalazide $6 \mathrm{~g}$ and $3 \mathrm{~g} /$ day. Twenty-three per cent of patients in the $6 \mathrm{~g} /$ day group relapsed compared to $33 \%$ of patients in the $3 \mathrm{~g}$ /day group ( 216 patients; RR $0.76 ; 95 \% \mathrm{Cl} 0.45$ to 2.79). One study found Balsalazide $4 \mathrm{~g}$ to be superior to $2 \mathrm{~g} /$ day. Thirty-seven per cent of patients in the $4 \mathrm{~g} /$ day Balsalazide group relapsed compared to $55 \%$ of patients in the $2 \mathrm{~g} /$ day group (133 patients; RR $0.66 ; 95 \% \mathrm{Cl} 0.45$ to 0.97 ). One study found a statistically significant difference between Salofalk granules $3 \mathrm{~g}$ and $1.5 \mathrm{~g} / \mathrm{day}$. Twenty-five per cent of patients in the Salofalk $3 \mathrm{~g} /$ day group relapsed compared to $39 \%$ of patients in the $1.5 \mathrm{~g} / \mathrm{day}$ group (429 patients; RR $0.65 ; 95 \% \mathrm{Cl} 0.49$ to 0.86 ). Common adverse events included flatulence, abdominal pain, nausea, diarrhea, headache, dyspepsia, and nasopharyngitis. There were no statistically significant differences in the incidence of adverse events between 5-ASA and placebo, 5-ASA and SASP, once daily and conventionally dosed 5-ASA, 5-ASA and comparator 5-ASA formulations and 5-ASA dose ranging studies. The trials that compared 5-ASA and SASP may have been biased in favour of SASP because most trials enrolled patients known to be tolerant to SASP which may have minimized SASP-related adverse events.

\section{Authors' conclusions}

5-ASA was superior to placebo for maintenance therapy in ulcerative colitis. However, 5-ASA had a statistically significant therapeutic inferiority relative to SASP. Oral 5-ASA administered once daily is as effective and safe as conventional dosing for maintenance of remission in quiescent ulcerative colitis. There does not appear to be any difference in efficacy or safety between the various formulations of 5-ASA. Patients with extensive ulcerative colitis or with frequent relapses may benefit from a higher dose of maintenance therapy. High dose therapy appears to be as safe as low dose and is not associated with a higher incidence of adverse events.

\section{PLAIN LANGUAGE SUMMARY}

\section{Oral 5-ASA compounds for maintaining remission in ulcerative colitis}

Sulfasalazine (SASP) has been used for treating ulcerative colitis for decades. SASP is made up of 5-aminosalicylic acid (5-ASA) linked to a sulfur molecule. Up to a third of patients treated with SASP have reported side effects, which are thought to be related to the sulfur part of the molecule. Common side effects associated with SASP include nausea, indigestion, headache, vomiting and abdominal pain. 5-ASA drugs were developed to avoid the side effects associated with SASP. This review includes 41 randomized trials with a total of 8928 participants. Oral 5-ASA was found to be more effective than placebo (fake drug) for maintaining remission. Although oral 5-ASA preparations are effective for maintaining remission in ulcerative colitis, they are no more effective than sulfasalazine (SASP) therapy. People who have become well can remain so by continuing to take either medication. There is no evidence that side effects are more frequent with one or the other medication. However, the side effects of 5-ASA may be notably less than those associated with SASP therapy. Common side effects associated with 5-ASA included flatulence, abdominal pain, nausea, diarrhea, headache, dyspepsia (indigestion), and nasopharyngitis (inflammation of the nasal passages). Most of the trials comparing 5-ASA with SASP enrolled patients who were known to tolerate SASP. This may have reduced SASP-related side effects in these trials. Male infertility is associated with SASP and not with 5ASA, so 5-ASA may be preferred for patients concerned about fertility. 5-ASA therapy is more expensive than SASP, so SASP may be the preferred option where cost is an important factor. Oral 5-ASA administered once daily is as effective and safe as conventional dosing (two or three times daily) for maintaining remission in ulcerative colitis. There does not appear to be any difference in efficacy or safety between the various formulations of 5-ASA. Patients with extensive ulcerative colitis or with frequent relapses may benefit from a higher dose of maintenance therapy. High dose therapy appears to be as safe as low dose and is not associated with a higher incidence of side effects. 
SUMMARY OF FINDINGS

Summary of findings for the main comparison. Oral 5-ASA versus placebo for maintenance of remission in ulcerative colitis

Oral 5-ASA versus placebo for maintenance of remission in ulcerative colitis

Patient or population: Patients with quiescent ulcerative colitis

Settings: Outpatients

Intervention: Oral 5-ASA versus placebo

\begin{tabular}{|c|c|c|c|c|c|c|}
\hline \multirow[t]{3}{*}{ Outcomes } & \multicolumn{2}{|c|}{ Illustrative comparative risks* $(95 \% \mathrm{Cl})$} & \multirow{3}{*}{$\begin{array}{l}\text { Relative effect } \\
(95 \% \mathrm{CI})\end{array}$} & \multirow{3}{*}{$\begin{array}{l}\text { No of Participants } \\
\text { (studies) }\end{array}$} & \multirow{3}{*}{$\begin{array}{l}\text { Quality of the } \\
\text { evidence } \\
\text { (GRADE) }\end{array}$} & \multirow[t]{3}{*}{ Comments } \\
\hline & Assumed risk & Corresponding risk & & & & \\
\hline & Control & $\begin{array}{l}\text { Oral 5-ASA versus } \\
\text { placebo }\end{array}$ & & & & \\
\hline $\begin{array}{l}\text { Failure to maintain clinical or en- } \\
\text { doscopic remission at study end- } \\
\text { point }\end{array}$ & 584 per $1000^{1}$ & $\begin{array}{l}\mathbf{4 0 3} \text { per } 1000 \\
\text { (362 to } 450)\end{array}$ & $\begin{array}{l}\mathbf{R R} \mathbf{0 . 6 9} \\
(0.62 \text { to } 0.77)\end{array}$ & $\begin{array}{l}1,298 \\
\text { ( } 7 \text { studies) }\end{array}$ & $\begin{array}{l}\oplus \oplus \oplus \oplus \\
\text { high }\end{array}$ & \\
\hline Any adverse event & 393 per $1000^{1}$ & $\begin{array}{l}369 \text { per } 1000 \\
\text { (303 to } 452)\end{array}$ & $\begin{array}{l}\mathbf{R R} 0.94 \\
\text { (0.77 to } 1.15)\end{array}$ & $\begin{array}{l}774 \\
\text { (3 studies) }\end{array}$ & $\begin{array}{l}\oplus \oplus \oplus \ominus \\
\text { moderate }^{2}\end{array}$ & \\
\hline Withdrawal due to adverse event & 42 per $1000^{1}$ & $\begin{array}{l}36 \text { per } 1000 \\
(19 \text { to } 68)\end{array}$ & $\begin{array}{l}\text { RR } 0.86 \\
\text { (0.46 to } 1.63)\end{array}$ & $\begin{array}{l}1096 \\
\text { (5 studies) }\end{array}$ & $\begin{array}{l}\oplus \oplus \oplus \ominus \\
\text { moderate } 3\end{array}$ & \\
\hline
\end{tabular}

*The basis for the assumed risk (e.g. the median control group risk across studies) is provided in footnotes. The corresponding risk (and its $95 \%$ confidence interval) is

based on the assumed risk in the comparison group and the relative effect of the intervention (and its 95\% $\mathrm{Cl}$ ).

Cl: Confidence interval; RR: risk ratio

GRADE Working Group grades of evidence

High quality: Further research is very unlikely to change our confidence in the estimate of effect.

Moderate quality: Further research is likely to have an important impact on our confidence in the estimate of effect and may change the estimate.

Low quality: Further research is very likely to have an important impact on our confidence in the estimate of effect and is likely to change the estimate.

Very low quality: We are very uncertain about the estimate.

1 Control group risk estimates come from control arm of meta-analysis, based on included trials.

2 Downgraded one level due to sparse data (320 events).

3 Downgraded one level due to sparse data (41 events). 
Summary of findings 2. Oral 5-ASA versus SASP for maintenance of remission in ulcerative colitis

Oral 5-ASA versus SASP for maintenance of remission in ulcerative colitis

Patient or population: Patients with quiescent ulcerative colitis

Settings: Outpatients

Intervention: Oral 5-ASA versus SASP

\begin{tabular}{|c|c|c|c|c|c|c|}
\hline \multirow[t]{3}{*}{ Outcomes } & \multicolumn{2}{|c|}{ Illustrative comparative risks $(95 \% \mathrm{Cl})$} & \multirow{3}{*}{$\begin{array}{l}\text { Relative effect } \\
(95 \% \mathrm{Cl})\end{array}$} & \multirow{3}{*}{$\begin{array}{l}\text { No of Participants } \\
\text { (studies) }\end{array}$} & \multirow{3}{*}{$\begin{array}{l}\text { Quality of the } \\
\text { evidence } \\
\text { (GRADE) }\end{array}$} & \multirow[t]{3}{*}{ Comments } \\
\hline & Assumed risk & $\begin{array}{l}\text { Corresponding } \\
\text { risk }\end{array}$ & & & & \\
\hline & Control & $\begin{array}{l}\text { Oral 5-ASA versus } \\
\text { SASP }\end{array}$ & & & & \\
\hline $\begin{array}{l}\text { Failure to maintain clinical or en- } \\
\text { doscopic remission at study end- } \\
\text { point }\end{array}$ & 429 per $1000^{1}$ & $\begin{array}{l}\mathbf{4 8 9} \text { per } 1000 \\
\text { (442 to } 545)\end{array}$ & $\begin{array}{l}\text { RR } 1.14 \\
\text { (1.03 to } 1.27)\end{array}$ & $\begin{array}{l}1,655 \\
\text { (12 studies) }\end{array}$ & $\begin{array}{l}\oplus \oplus \oplus \oplus \\
\text { high }\end{array}$ & \\
\hline Any adverse event & 158 per $1000^{1}$ & $\begin{array}{l}\mathbf{1 6 9} \text { per } 1000 \\
(130 \text { to } 221)\end{array}$ & $\begin{array}{l}\text { RR } 1.07 \\
\text { (0.82 to } 1.40)\end{array}$ & $\begin{array}{l}1,138 \\
\text { (7 studies) }\end{array}$ & $\begin{array}{l}\oplus \oplus \oplus \ominus \\
\text { moderate }^{2}\end{array}$ & \\
\hline Withdrawal due to adverse event & 54 per $1000^{1}$ & $\begin{array}{l}69 \text { per } 1000 \\
(47 \text { to } 101)\end{array}$ & $\begin{array}{l}\text { RR } 1.27 \\
\text { (0.87 to } 1.87 \text { ) }\end{array}$ & $\begin{array}{l}1,585 \\
\text { (10 studies) }\end{array}$ & $\begin{array}{l}\oplus \oplus \oplus \ominus \\
\text { moderate }^{3}\end{array}$ & \\
\hline
\end{tabular}

*The basis for the assumed risk (e.g. the median control group risk across studies) is provided in footnotes. The corresponding risk (and its $95 \%$ confidence interval) is based on the assumed risk in the comparison group and the relative effect of the intervention (and its $95 \% \mathrm{Cl}$ ).

Cl: Confidence interval; RR: risk ratio

GRADE Working Group grades of evidence

High quality: Further research is very unlikely to change our confidence in the estimate of effect.

Moderate quality: Further research is likely to have an important impact on our confidence in the estimate of effect and may change the estimate.

Low quality: Further research is very likely to have an important impact on our confidence in the estimate of effect and is likely to change the estimate.

Very low quality: We are very uncertain about the estimate.

${ }^{1}$ Control group risk estimates come from control arm of meta-analysis, based on included trials

2 Downgraded one level due to sparse data (182 events).

3 Downgraded one level due to sparse data (97 events). 


\begin{tabular}{|c|c|c|c|c|c|c|}
\hline \multicolumn{7}{|c|}{ Once daily dosing versus conventional dosing for maintenance of remission in ulcerative colitis } \\
\hline \multicolumn{7}{|c|}{$\begin{array}{l}\text { Patient or population: Patients with quiescent ulcerative colitis } \\
\text { Settings: Outpatients } \\
\text { Intervention: Once daily oral 5-ASA versus conventional dosing of 5-ASA }\end{array}$} \\
\hline \multirow[t]{3}{*}{ Outcomes } & \multicolumn{2}{|c|}{ Illustrative comparative risks* $(95 \% \mathrm{Cl})$} & \multirow{3}{*}{$\begin{array}{l}\text { Relative effect } \\
(95 \% \mathrm{Cl})\end{array}$} & \multirow{3}{*}{$\begin{array}{l}\text { No of Participants } \\
\text { (studies) }\end{array}$} & \multirow{3}{*}{$\begin{array}{l}\text { Quality of the } \\
\text { evidence } \\
\text { (GRADE) }\end{array}$} & \multirow{3}{*}{ Comments } \\
\hline & Assumed risk & Corresponding risk & & & & \\
\hline & Control & OD versus conventional & & & & \\
\hline $\begin{array}{l}\text { Failure to maintain clinical } \\
\text { or endoscopic remission at } \\
6 \text { months }\end{array}$ & 184 per $1000^{1}$ & $\begin{array}{l}\mathbf{1 8 8} \text { per } \mathbf{1 0 0 0} \\
\text { (157 to } 228)\end{array}$ & $\begin{array}{l}\text { RR } 1.02 \\
\text { (0.85 to } 1.23)\end{array}$ & $\begin{array}{l}1,871 \\
\text { (3 studies) }\end{array}$ & $\begin{array}{l}\oplus \oplus \ominus \ominus \\
\text { low } 2,3\end{array}$ & \\
\hline $\begin{array}{l}\text { Failure to maintain clinical } \\
\text { or endoscopic remission at } \\
12 \text { months }\end{array}$ & 314 per $1000^{1}$ & $\begin{array}{l}\mathbf{2 8 6} \text { per } \mathbf{1 0 0 0} \\
\text { (258 to } 317)\end{array}$ & $\begin{array}{l}\text { RR } 0.91 \\
\text { (0.82 to } 1.01)\end{array}$ & $\begin{array}{l}3,127 \\
\text { (8 studies) }\end{array}$ & $\begin{array}{l}\oplus \oplus \oplus \ominus \\
\text { moderate }^{4}\end{array}$ & \\
\hline $\begin{array}{l}\text { Failure to adhere to study } \\
\text { medication regimen }\end{array}$ & 87 per $1000^{1}$ & $\begin{array}{l}106 \text { per } 1000 \\
\text { (79 to } 143)\end{array}$ & $\begin{array}{l}\text { RR } 1.22 \\
\text { (0.91 to } 1.64)\end{array}$ & $\begin{array}{l}1,462 \\
\text { ( } 6 \text { studies) }\end{array}$ & $\begin{array}{l}\oplus \oplus \oplus \ominus \\
\text { moderate } 5,6\end{array}$ & \\
\hline $\begin{array}{l}\text { Development of any ad- } \\
\text { verse event }\end{array}$ & 453 per $1000^{1}$ & $\begin{array}{l}\mathbf{4 5 3} \text { per } 1000 \\
\text { (417 to } 489)\end{array}$ & $\begin{array}{l}\text { RR } 1.00 \\
(0.92 \text { to } 1.08)\end{array}$ & $\begin{array}{l}2,714 \\
\text { (6 studies) }\end{array}$ & $\begin{array}{l}\oplus \oplus \oplus \oplus \\
\text { high }\end{array}$ & \\
\hline $\begin{array}{l}\text { Withdrawal due to adverse } \\
\text { events }\end{array}$ & 15 per $1000^{1}$ & $\begin{array}{l}\mathbf{2 0} \text { per } \mathbf{1 0 0 0} \\
(12 \text { to } 32)\end{array}$ & $\begin{array}{l}\text { RR } 1.31 \\
\text { (0.80 to } 2.13 \text { ) }\end{array}$ & $\begin{array}{l}3,737 \\
\text { (7 studies) }\end{array}$ & $\begin{array}{l}\oplus \oplus \ominus \ominus \\
\text { low }^{7,8}\end{array}$ & \\
\hline
\end{tabular}

${ }^{*}$ The basis for the assumed risk (e.g. the median control group risk across studies) is provided in footnotes. The corresponding risk (and its $95 \%$ confidence interval) is based on the assumed risk in the comparison group and the relative effect of the intervention (and its $95 \% \mathrm{Cl}$ ).

Cl: Confidence interval; RR: risk ratio

GRADE Working Group grades of evidence

High quality: Further research is very unlikely to change our confidence in the estimate of effect.

Moderate quality: Further research is likely to have an important impact on our confidence in the estimate of effect and may change the estimate.

Low quality: Further research is very likely to have an important impact on our confidence in the estimate of effect and is likely to change the estimate.

Very low quality: We are very uncertain about the estimate.

1 Control group risk estimates come from control arm of meta-analysis, based on included trials.

2 Downgraded one level due to risk of bias. Two studies in the pooled analysis were single-blind (investigator blind).

v 3 Downgraded one level due to sparse data (349 events). 
${ }^{4}$ Downgraded one level due to risk of bias. One study in the pooled analysis was open-label and was rated as a high risk of bias due to lack of blinding. Four studies in the pooled analysis were single-blind (investigator blinded).

5 Downgraded one level due to sparse data (146 events).

6 Adherence was calculated using objective data (pill count or pharmacy data) in 4 of 6 studies in the analysis. One study used patient self-report to calculate adherence and one study did not describe how adherence was assessed.

7 Downgraded one level due to sparse data (64 events).

8 Downgraded one level due to risk of bias. One study in the pooled analysis was open-label and was rated as a high risk of bias due to lack of blinding. Three studies in the pooled analysis were single-blind (investigator blinded).

\section{Summary of findings 4. Oral 5-ASA versus comparator 5-ASA formulation for maintenance of remission in ulcerative colitis}

Oral 5-ASA versus comparator 5-ASA formulation for maintenance of remission in ulcerative colitis

Patient or population: Patients with quiescent ulcerative colitis

Settings: Outpatients

Intervention: Oral 5-ASA versus 5-ASA (different formulations)

\begin{tabular}{|c|c|c|c|c|c|c|}
\hline \multirow[t]{3}{*}{ Outcomes } & \multicolumn{2}{|c|}{ Illustrative comparative risks* $(95 \% \mathrm{CI})$} & \multirow{3}{*}{$\begin{array}{l}\text { Relative effect } \\
(95 \% \mathrm{CI})\end{array}$} & \multirow{3}{*}{$\begin{array}{l}\text { No of Partici- } \\
\text { pants } \\
\text { (studies) }\end{array}$} & \multirow{3}{*}{$\begin{array}{l}\text { Quality of the } \\
\text { evidence } \\
\text { (GRADE) }\end{array}$} & \multirow[t]{3}{*}{ Comments } \\
\hline & Assumed risk & Corresponding risk & & & & \\
\hline & Control & Oral 5-ASA versus 5-ASA & & & & \\
\hline $\begin{array}{l}\text { Failure to maintain clinical } \\
\text { or endoscopic remission at } \\
12 \text { months }\end{array}$ & 407 per $1000^{1}$ & $\begin{array}{l}\mathbf{4 4 0} \text { per } 1000 \\
(370 \text { to } 521)\end{array}$ & $\begin{array}{l}\mathbf{R R} \mathbf{1 . 0 8} \\
(0.91 \text { to } 1.28)\end{array}$ & $\begin{array}{l}707 \\
\text { (6 studies) }\end{array}$ & $\begin{array}{l}\oplus \oplus \oplus \ominus \\
\text { low2,3 }\end{array}$ & \\
\hline $\begin{array}{l}\text { Development of any ad- } \\
\text { verse event }\end{array}$ & 686 per $1000^{1}$ & $\begin{array}{l}\mathbf{6 4 5} \text { per } 1000 \\
\text { (569 to } 734)\end{array}$ & $\begin{array}{l}\text { RR } 0.94 \\
\text { (0.83 to } 1.07)\end{array}$ & $\begin{array}{l}357 \\
\text { (4 studies) }\end{array}$ & $\begin{array}{l}\oplus \oplus \oplus \ominus \\
\text { low } 4,5\end{array}$ & \\
\hline $\begin{array}{l}\text { Withdrawal due to adverse } \\
\text { events }\end{array}$ & 44 per $1000^{1}$ & $\begin{array}{l}\mathbf{5 5} \text { per } \mathbf{1 0 0 0} \\
(25 \text { to } 122)\end{array}$ & $\begin{array}{l}\text { RR } 1.25 \\
\text { (0.56 to } 2.78 \text { ) }\end{array}$ & $\begin{array}{l}457 \\
\text { (5 studies) }\end{array}$ & $\begin{array}{l}\oplus \ominus \ominus \ominus \\
\text { very low6 } 6,7\end{array}$ & \\
\hline
\end{tabular}

*The basis for the assumed risk (e.g. the median control group risk across studies) is provided in footnotes. The corresponding risk (and its $95 \%$ confidence interval) is based on the assumed risk in the comparison group and the relative effect of the intervention (and its $95 \% \mathrm{Cl}$ ).

Cl: Confidence interval; RR: risk ratio

GRADE Working Group grades of evidence

High quality: Further research is very unlikely to change our confidence in the estimate of effect.

Moderate quality: Further research is likely to have an important impact on our confidence in the estimate of effect and may change the estimate.

Low quality: Further research is very likely to have an important impact on our confidence in the estimate of effect and is likely to change the estimate.

Very low quality: We are very uncertain about the estimate. 
1 Control group risk estimates come from control arm of meta-analysis, based on included trials

2 Downgraded one level due to sparse data (300 events).

3 Downgraded one level due to risk of bias. Two studies in pooled analysis were single blind and one was open label.

4 Downgraded one level due to sparse data (236 events).

5 Downgraded one level due to risk of bias. One study in the pooled analysis was open label.

6 Downgraded two levels due to very sparse data (23 events) and very wide confidence intervals.

7 Downgraded one level due to risk of bias. One study in the pooled analysis due was single blind and another was open label.

Summary of findings 5. High dose oral 5-ASA versus low dose 5-ASA for maintenance of remission in ulcerative colitis

High dose oral 5-ASA versus low dose 5-ASA for maintenance of remission in ulcerative colitis

Patient or population: Patients with quiescent ulcerative colitis

Settings: Outpatients

Intervention: High dose oral 5-ASA versus low dose 5-ASA

\begin{tabular}{|c|c|c|c|c|c|c|}
\hline \multirow[t]{3}{*}{ Outcomes } & \multicolumn{2}{|c|}{ Illustrative comparative risks* $(95 \% \mathrm{CI})$} & \multirow{3}{*}{$\begin{array}{l}\text { Relative effect } \\
(95 \% \mathrm{Cl})\end{array}$} & \multirow{3}{*}{$\begin{array}{l}\text { No of Partici- } \\
\text { pants } \\
\text { (studies) }\end{array}$} & \multirow{3}{*}{$\begin{array}{l}\text { Quality of the } \\
\text { evidence } \\
\text { (GRADE) }\end{array}$} & \multirow[t]{3}{*}{ Comments } \\
\hline & Assumed risk & Corresponding risk & & & & \\
\hline & Control & $\begin{array}{l}\text { High dose 5-ASA versus } \\
\text { low dose 5-ASA }\end{array}$ & & & & \\
\hline $\begin{array}{l}\text { Failure to maintain clinical or endo- } \\
\text { scopic remission at } 12 \text { months }\end{array}$ & 357 per $1000^{1}$ & $\begin{array}{l}\mathbf{2 8 6} \text { per } \mathbf{1 0 0 0} \\
\text { (164 to } 493)\end{array}$ & $\begin{array}{l}\mathbf{R R} \mathbf{0 . 8 0} \\
(0.46 \text { to } 1.38)\end{array}$ & $\begin{array}{l}112 \\
\text { (1 study) }\end{array}$ & $\begin{array}{l}\oplus \ominus \ominus \ominus \\
\text { very low } 2,3\end{array}$ & $\begin{array}{l}\text { Asacol } 4.8 \mathrm{~g} / \text { day versus } \\
2.4 \mathrm{~g} / \text { day }\end{array}$ \\
\hline $\begin{array}{l}\text { Failure to maintain clinical or endo- } \\
\text { scopic remission at } 12 \text { months }\end{array}$ & 330 per $1000^{1}$ & $\begin{array}{l}\mathbf{2 5 1} \text { per } 1000 \\
(69 \text { to } 921)\end{array}$ & $\begin{array}{l}\text { RR } \mathbf{0 . 7 6} \\
\text { (0.21 to } 2.79)\end{array}$ & $\begin{array}{l}216 \\
\text { ( } 2 \text { studies) }\end{array}$ & $\begin{array}{l}\oplus \ominus \ominus \ominus \\
\text { very low } 34,5\end{array}$ & $\begin{array}{l}\text { Balsalazide } 6.0 \mathrm{~g} / \text { day } \\
\text { versus } 3.0 \mathrm{~g} / \text { day }\end{array}$ \\
\hline $\begin{array}{l}\text { Failure to maintain clinical or endo- } \\
\text { scopic remission at } 12 \text { months }\end{array}$ & 554 per $1000^{1}$ & $\begin{array}{l}366 \text { per } 1000 \\
\text { (249 to } 537)\end{array}$ & $\begin{array}{l}\text { RR } \mathbf{0 . 6 6} \\
(0.45 \text { to } 0.97)\end{array}$ & $\begin{array}{l}133 \\
\text { (1 study) }\end{array}$ & $\begin{array}{l}\oplus \oplus \oplus \ominus \\
\text { moderate }\end{array}$ & $\begin{array}{l}\text { Balsalazide } 4.0 \mathrm{~g} / \text { day } \\
\text { versus } 2.0 \mathrm{~g} / \text { day }\end{array}$ \\
\hline $\begin{array}{l}\text { Failure to maintain clinical or endo- } \\
\text { scopic remission at } 12 \text { months }\end{array}$ & 392 per $1000^{1}$ & $\begin{array}{l}\mathbf{2 5 5} \text { per } \mathbf{1 0 0 0} \\
\text { (192 to } 337)\end{array}$ & $\begin{array}{l}\text { RR } 0.65 \\
\text { (0.49 to } 0.86)\end{array}$ & $\begin{array}{l}429 \\
\text { (1 study) }\end{array}$ & $\begin{array}{l}\oplus \oplus \oplus \ominus \\
\text { moderate }^{7}\end{array}$ & $\begin{array}{l}\text { Salofalk granules } 3.0 \mathrm{~g} \\
\text { OD versus } 1.5 \mathrm{~g} \text { OD }\end{array}$ \\
\hline
\end{tabular}

*The basis for the assumed risk (e.g. the median control group risk across studies) is provided in footnotes. The corresponding risk (and its $95 \%$ confidence interval) is based on the assumed risk in the comparison group and the relative effect of the intervention (and its $95 \% \mathrm{Cl}$ ).

Cl: Confidence interval; RR: risk ratio; OD: once daily

GRADE Working Group grades of evidence

High quality: Further research is very unlikely to change our confidence in the estimate of effect.

Moderate quality: Further research is likely to have an important impact on our confidence in the estimate of effect and may change the estimate.

Low quality: Further research is very likely to have an important impact on our confidence in the estimate of effect and is likely to change the estimate. 
1 Control group risk estimates come from control arm of meta-analysis, based on included trials.

2 Downgraded two levels due to very sparse data (36 events).

3 Downgraded one due to high risk of bias (open label study).

4 Downgraded one level due to sparse data (61 events) and very wide confidence intervals.

5 Downgraded two levels due to very serious inconsistency $(12=86 \%)$

6 Downgraded one level due to sparse data (61 events) and wide confidence intervals.

7 Downgraded one level due to sparse data (138 events). 


\section{B A C K G R O U N D}

The successful management of ulcerative colitis was greatly facilitated after the introduction of sulfasalazine (SASP) by Svartz (Svartz 1942). SASP is composed of 5-aminosalicylic acid (5-ASA) linked to sulfapyridine via a diazo bond. This bond is readily cleaved by bacterial azoreductases in the colon (Peppercorn 1972) to yield the two components. Of these, 5-ASA has been found to be the therapeutically active component, while sulfapyridine, which is primarily absorbed into systemic circulation, is assumed to function solely as a carrier molecule (Azad Khan 1977; Van Hees 1980; Klotz 1980).

Administration of unbound or uncoated 5-ASA revealed that it was readily absorbed in the upper jejunum and was unable to reach the colon in therapeutic concentrations (Schroeder 1972; Nielsen 1983; Myers 1987). Ingested SASP largely resists such premature absorption and thus is able to serve as a delivery system that transports the 5-ASA to the affected regions of the lower intestinal tract (Schroeder 1972). While corticosteroid therapy is more effective in the treatment of severe ulcerative colitis (Truelove 1955; Truelove 1959) the use of SASP in maintaining remission (Misiewitz 1965) has been well established.

Despite its benefits, up to $30 \%$ of patients receiving SASP have reported adverse side-effects (Nielsen 1982). It was concluded that many were due to the sulfapyridine moiety, especially those effects found to be dose-dependent (Das 1973; Myers 1987). This discovery spawned more than a decade of research aimed at finding alternative 5-ASA delivery systems.

Asacol ${ }^{\circledR}$ (Proctor and Gamble) consists of a pellet of 5-ASA destined for release in the terminal ileum or colon due to a coating known as Eudragit-S, a resin that dissolves at a pH greater than 7 (Dew 1982a). Claversal ${ }^{\circledR}$ or Mesasal ${ }^{\circledast}$ (GlaxoSmithKline), Salofalk ${ }^{\circledast}$ (Axcan Pharma, Falk Foundation), and Rowasa ${ }^{\circledR}$ (Reid-Rowell) are similar delayed-release preparations of 5-ASA pellets coated with Eudragit $\mathrm{L}$, a resin that dissolves at a $\mathrm{pH}$ greater than 6 (the approximate pH of the ileum/colon) (Hardy 1987; Myers 1987). Pentasa ${ }^{\circledR}$ (MarionMerrell-Dow) is a microsphere formulation that consists of 5-ASA microgranules enclosed within a semi-permeable membrane of ethylcellulose. It is designed for controlled release that begins in the duodenum and continues into the affected regions of the lower bowel (Rasmussen 1982). Olsalazine or Dipentum ${ }^{\circledR}$ (Pharmacia \& Upjohn) consists of two 5-ASA molecules linked by a diazo bond (Willoughby 1982; Staerk Laursen 1990). Other formulations, such as benzalazine and balsalazide, are composed of 5-ASA molecules azo-bonded to various benzoic acid derivatives (Chan 1983; Fleig 1988). Like SASP, these compounds are poorly absorbed in the upper digestive tract but are readily metabolized by the intestinal flora in the lower bowel. MMX mesalamine (Lialdaa ${ }^{\circledR}$ or Mezavanta ${ }^{\circledR}$ ) uses MMX Multi Matrix System (MMX) technology to delay and extend delivery of active drug throughout the colon (Kamm 2008).

The newer 5-ASA preparations were intended to avoid the adverse effects of SASP while maintaining its therapeutic benefits. These drugs are more costly, however, and have still been shown to cause adverse effects in some patients (Rao 1987). The efficacy and safety of the 5-ASA preparations have been evaluated in numerous clinical trials that have often lacked sufficient statistical power to arrive at definitive conclusions. In an earlier meta-analysis, Sutherland 1993 found that the newer 5-ASA drugs were no more effective than SASP for maintenance of remission in ulcerative colitis. This systematic review is an update of the Cochrane review published in 2012 (Feagan 2012). We proceeded with this updated review, in accordance with the format of the Cochrane Collaboration, in order to include the more recent studies as well as to evaluate the effectiveness, dose-responsiveness, and safety of the 5-ASA preparations in terms of more precise outcome measures.

Many patients are non-adherent with conventional multi-dose ( 2 or 3 times daily) treatment regimens which may result in reduced efficacy, and can lead to an increased risk of relapse in patients with quiescent disease (Kane 2001; Kane 2003b), poor long-term prognosis (Kane 2008b) and increased costs of care (Kane 2008b; Beaulieu 2009). Poor adherence may be particularly problematic in quiescent disease (Kane 2001; Kane 2003b), since patients lack continuing symptoms that incentivize them to take medication. Although multiple factors have been shown to influence medication adherence in patients with ulcerative colitis it is commonly believed that a high pill burden and multi-dose regimens are major determinants (Ediger 2007; Kane 2008b). Accordingly, it is reasonable to hypothesize that once daily dosing of mesalamine might improve both adherence with maintenance therapy and outcomes.

The efficacy and safety of once daily oral dosing of mesalamine compared to conventional dosing (two or three times daily) for the treatment of ulcerative colitis has been evaluated in numerous clinical trials. These trials have investigated the efficacy of once daily dosing of various formulations of mesalamine compared to conventional dosing schedules of the same drugs or different formulations. Many of these trials were small in size and lacked sufficient statistical power to arrive at definitive conclusions. A secondary objective of this systematic review was to investigate the efficacy and safety of once daily dosing of mesalamine compared to conventional dosing for the treatment quiescent ulcerative colitis.

\section{O B J E C T IVES}

The primary objectives were to assess the efficacy, doseresponsiveness, and safety of oral 5-aminosalicylic acid (5-ASA) compared to placebo, sulfasalazine (SASP), or 5-ASA comparators (i.e. other formulations of 5-ASA) for maintenance of remission in quiescent ulcerative colitis. A secondary objective of this systematic review was to compare the efficacy and safety of once daily dosing of oral 5-ASA with conventional dosing regimens.

\section{METHO D S}

\section{Criteria for considering studies for this review}

\section{Types of studies}

Prospective, randomized controlled trials of parallel design, with a minimum treatment duration of six months were considered for inclusion.

\section{Types of participants}

Patients of any age with mild-to-moderate ulcerative colitis in remission as defined by Truelove and Witts (Truelove 1955) were considered for inclusion.

\section{Types of interventions}

Trials of oral 5-ASA therapy for treatment of patients with ulcerative colitis in remission compared with placebo, SASP or 
other formulations of 5-ASA were considered for inclusion. Studies that compared once daily 5-ASA treatment with conventional dosing of 5-ASA (two or three times daily) and 5-ASA dose ranging studies were also considered for inclusion.

\section{Types of outcome measures}

Outcome measures included endoscopic or clinical relapse, or early withdrawal, as defined by the authors of each study.

\section{Primary outcomes}

The primary outcome was endoscopic or clinical relapse as defined by the authors of each study.

\section{Secondary outcomes}

Secondary outcomes included:

- the proportion of patients who failed to adhere with their medication regimen;

- the proportion of patients who experienced at least one adverse event;

- the proportion of patients who withdrew due to adverse events; and

- the proportion of patients excluded or withdrawn after entry.

\section{Search methods for identification of studies}

MEDLINE (OvidSP), EMBASE (Ovid SP), and the Cochrane Library were searched from inception to January 20,2012. No language or document type restrictions were applied. The multipurpose search command for the Ovid SP interface (.mp.) was used to search both text and database subject heading fields. Review articles and conference proceedings were also searched to identify additional studies. The search strategies are listed in Appendix 1.

\section{Data collection and analysis}

\section{Study Selection}

Relevant studies were selected on the basis of the above criteria. When necessary, the original authors were contacted to clarify points regarding trial methodology. The reasons for exclusion are indicated for each ineligible study.

\section{Data Collection}

Each study selected for analysis was independently reviewed by two authors. Data were recorded onto standard data extraction forms by each author. Any discrepancies between authors were settled by consensus. Results were recorded on an intention-totreat basis, regardless of whether the original authors had done so.

\section{Outcome Measures}

The primary outcome of interest was the failure to maintain clinical or endoscopic remission as evidenced by disease relapse, the criteria for which were defined by the authors of each trial. Data were also extracted, where possible, to investigate the influence of the dose of 5-ASA. As well, the numbers of patients who experienced adverse effects, withdrawal from the study due to adverse events, and exclusion or withdrawal from therapy were recorded where the data were available.

\section{Risk of bias assessment}

Two authors independently assessed the risk of bias in the included studies using the Cochrane risk of bias tool (Higgins 2011). Factors assessed included:

1. sequence generation (i.e. was the allocation sequence adequately generated?);

2. allocation sequence concealment (i.e. was allocation adequately concealed?);

3. blinding (i.e. was knowledge of the allocated intervention adequately prevented during the study?);

4. incomplete outcome data (i.e. were incomplete outcome data adequately addressed?);

5. selective outcome reporting (i.e. are reports of the study free of suggestion of selective outcome reporting?); and

6. other potential sources of bias (i.e. was the study apparently free of other problems that could put it at a high risk of bias?).

A judgement of 'Yes' indicates low risk of bias, 'No' indicates high risk of bias, and 'Unclear' indicates unclear or unknown risk of bias. Disagreements were resolved by consensus. Study authors were contacted when insufficient information was provided to determine risk of bias.

We used the GRADE approach for rating the overall quality of evidence for primary outcomes and selected secondary outcomes of interest. Randomized trials start as high quality evidence, but may be downgraded due to: (1) limitations in design and implementation (risk of bias), (2) indirectness of evidence, (3) inconsistency (unexplained heterogeneity), (4) imprecision (sparse data), and (5) reporting bias (publication bias). The overall quality of evidence for each outcome was determined after considering each of these elements, and categorized as high quality (i.e. further research is very unlikely to change our confidence in the estimate of effect); moderate quality (i.e. further research is likely to have an important impact on our confidence in the estimate of effect and may change the estimate); low quality (i.e. further research is very likely to have an important impact on our confidence in the estimate of effect and is likely to change the estimate); and very low quality (i.e. we are very uncertain about the estimate) (Guyatt 2008; Schünemann 2011).

\section{Statistical Methods}

Trials were separated into five comparison groups: 5-ASA versus placebo, 5-ASA versus sulfasalazine, once daily dosing versus conventional dosing, 5-ASA versus comparator 5-ASA formulation, and 5-ASA dose-ranging. Within each group, raw data for every measured outcome were extracted and converted into individual two by two tables. The tables for placebo-controlled trials were further subgrouped according to the dose of 5-ASA. The tables for the once daily versus conventional dosing studies were subgrouped by formulation. The tables for 5-ASA-controlled trials were subgrouped by common 5-ASA comparators (e.g. Asacol and Salofalk). The tables for dose-ranging studies were subgrouped by 5-ASA formulation. The risk ratio (RR) and 95\% confidence intervals $(95 \% \mathrm{Cl})$ derived from each two by two table were individually calculated and plotted. The results for each comparison group were pooled to determine the RR and $95 \% \mathrm{Cl}$ for each outcome resulting from 5-ASA therapy relative to either placebo, SASP or 5ASA comparator formulation and once daily 5-ASA therapy relative to conventional dosing. A fixed-effect model was used. Studies were pooled for analysis if patients, outcomes and interventions 
were similar (determined by consensus among authors). Studies comparing 5-ASA to comparator 5-ASA formulations were pooled for analysis if they compared equimolar doses of oral 5-ASA.

Dose-responsiveness was analyzed using a $\mathrm{Chi}^{2}$ for trend. Trials were also subgrouped according to the specific 5-ASA preparation for those outcomes for which there were two or more studies that used a similar drug. Tests for homogeneity among trials within each comparison group were performed. The presence of heterogeneity among studies was assessed using the $\mathrm{Chi}^{2}$ test (a P value of 0.10 was regarded as statistically significant) and the 12 statistic (Higgins 2003). If statistically significant heterogeneity was identified, the $\mathrm{RR}$ and $95 \% \mathrm{Cl}$ were calculated using a random-effects model. We conducted sensitivity analyses as appropriate to investigate heterogeneity. We also conducted sensitivity analyses excluding studies with a high risk of bias. All statistical analyses were performed using the Cochrane Collaboration RevMan 5 software package.

\section{RES U L T S}

\section{Description of studies}

A literature search conducted on July 9, 2015 identified 2525 studies. Eleven additional studies were identified through searching of references. After duplicates were removed a total of 1619 reports remained for review of titles and abstracts. Two authors independently reviewed the titles and abstracts of these studies and 112 reports of oral 5-ASA maintenance treatment for quiescent ulcerative colitis were selected for full text review (See Figure 1). Thirty reports of 28 studies were excluded (See Characteristics of excluded studies). Eighty-two reports of 41 studies involving a total of 8928 patients were selected for inclusion (Dew 1983a; Sandberg-Gertzen 1986; Andreoli 1987; Ireland 1988; McIntyre 1988; Mulder 1988; Riley 1988; Rutgeerts 1989; Courtney 1992; Giaffer 1992a; Green 1992; Kiilerich 1992; Rijk 1992; Wright 1993; Travis 1994; Ardizzone 1995; Fockens 1995; Kruis 1995; Miner 1995; Nilsson 1995; Hanauer 1996; Hawkey 1997; Green 1998; Ardizzone 1999; Deventer 2001; Kruis 2001; Mahmud 2002; Kane 2003a; Paoluzi 2005; Kamm 2008; Kane 2008a; Dignass 2009; Prantera 2009; Ito 2010; Lichtenstein 2010; Sandborn 2010; Kruis 2011; D'Haens 2012; Hawthorne 2012; Pica 2012; Watanabe 2013) (See Characteristics of included studies). 
Figure 1. Study flow diagram.

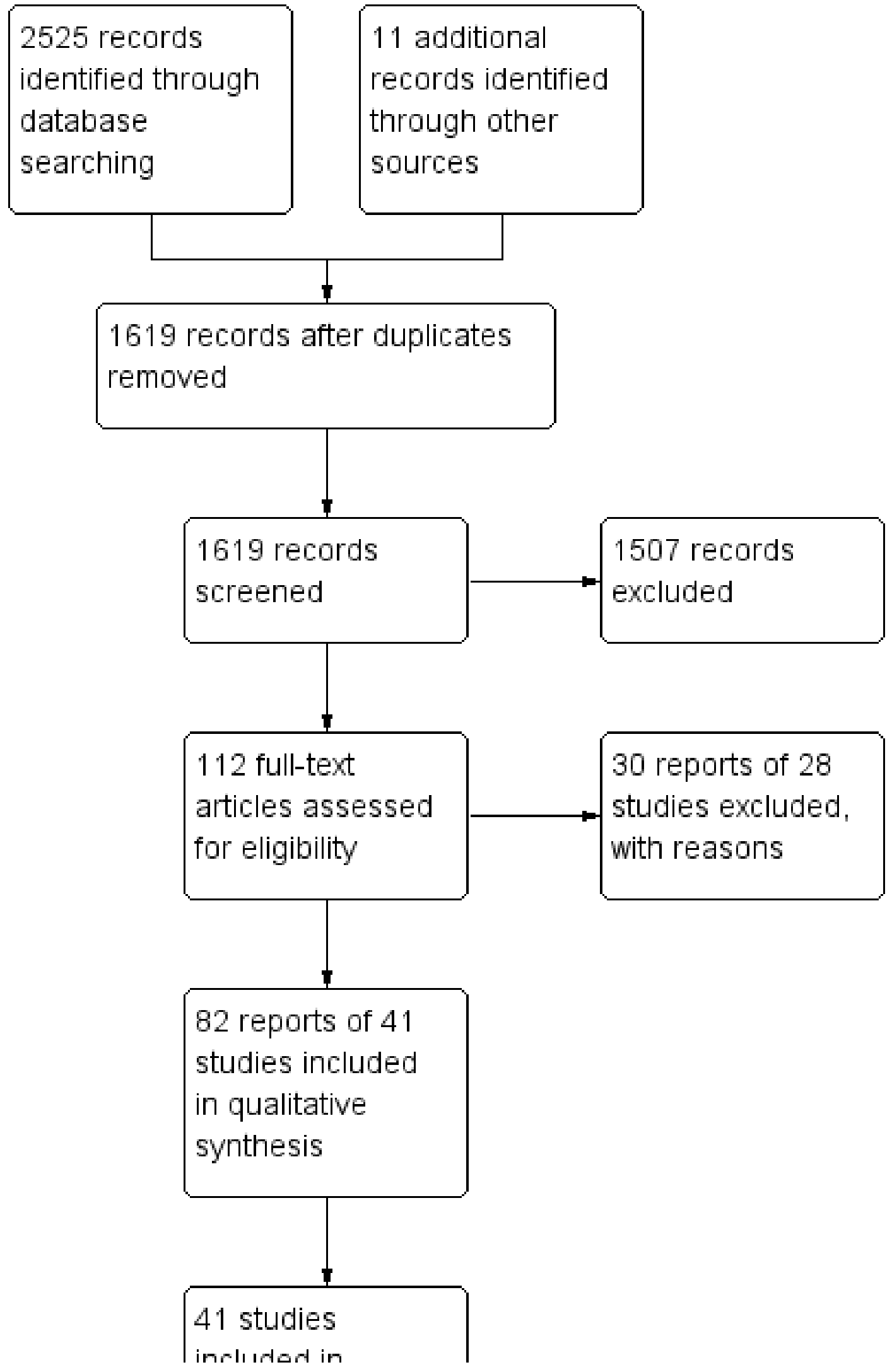


Figure 1. (Continued)

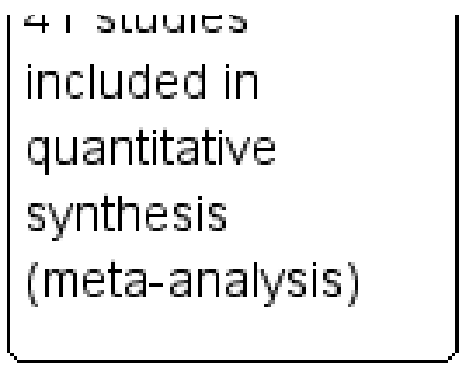

Seven studies were placebo-controlled (Sandberg-Gertzen 1986; Wright 1993; Miner 1995; Hanauer 1996; Hawkey 1997; Ardizzone 1999; Lichtenstein 2010). Twelve studies compared 5-ASA to SASP (Dew 1983a; Andreoli 1987; Ireland 1988; Mclntyre 1988; Mulder 1988; Riley 1988; Rutgeerts 1989; Kiilerich 1992; Rijk 1992; Ardizzone 1995; Kruis 1995; Nilsson 1995). Ten studies were maintenance of remission studies comparing once daily dosing of mesalamine with conventional dosing (Kane 2003a; Kamm 2008; Kane 2008a; Dignass 2009; Prantera 2009; Sandborn 2010; Hawthorne 2012; Kruis 2011; D'Haens 2012; Watanabe 2013). Six studies compared the efficacy and safety of various formulations of oral 5-ASA to other formulations of oral 5-ASA for maintenance treatment (Courtney 1992; Green 1998; Deventer 2001; Kruis 2001; Mahmud 2002; Ito 2010). Ten trials were dose-ranging studies of oral 5-ASA (Giaffer 1992a; Green 1992; Travis 1994; Fockens 1995; Hanauer 1996; Deventer 2001; Kruis 2001; Paoluzi 2005; Kruis 2011; Pica 2012). Six of the included studies were formal non-inferiority studies (Dignass 2009; Ito 2010; Sandborn 2010; Hawthorne 2012; D'Haens 2012; Watanabe 2013).

\section{Risk of bias in included studies}

A summary of the risk of bias assessment is provided in Figure 2. Most of the included studies were of high methodological quality. Ten studies were rated as high risk of bias. Seven of these studies were single-blind (Courtney 1992; Deventer 2001; Kane 2003a; Kane 2008a; Dignass 2009; Sandborn 2010; Hawthorne 2012). Outcomes were assessed by a blinded investigator in these studies. Three studies were open-label and investigators and patients were not blinded to treatment assignment (Mahmud 2002; Kamm 2008; Pica 2012). However, two of the open-label studies (Mahmud 2002; Kamm 2008) and 4 of 7 single-blind studies (Courtney 1992; Kane 2008a; Dignass 2009; Hawthorne 2012) utilized investigator performed endoscopy as an endpoint, which may protect against bias provided the endoscopist is blinded. The methods used for blinding were not described in one study and this study was rated as unclear (Green 1992). Twenty-nine of 41 included studies did not describe the method used for randomization and were rated as unclear for this item (Dew 1983a; Sandberg-Gertzen 1986; Ireland 1988; McIntyre 1988; Mulder 1988; Riley 1988; Rutgeerts 1989; Giaffer 1992a; Green 1992; Rijk 1992; Wright 1993; Travis 1994; Ardizzone 1995; Miner 1995; Nilsson 1995; Hawkey 1997; Green 1998; Ardizzone 1999; Deventer 2001; Kruis 2001; Paoluzi 2005; Kamm 2008; Dignass 2009; Lichtenstein 2010; Sandborn 2010; Hawthorne 2012; D'Haens 2012; Pica 2012; Watanabe 2013). Eighteen studies did not describe methods used for allocation concealment and were rated as unclear for this item (Dew 1983a; Andreoli 1987; Courtney 1992; Giaffer 1992a; Green 1992; Travis 1994; Ardizzone 1995; Fockens 1995; Green 1998; Ardizzone 1999; Deventer 2001; Kruis 2001; Mahmud 2002; Paoluzi 2005; Lichtenstein 2010; Hawthorne 2012; Pica 2012; Watanabe 2013). Thirteen studies were rated as unclear for incomplete outcome data because reasons for withdrawal were not described (Dew 1983a; Sandberg-Gertzen 1986; Andreoli 1987; Rutgeerts 1989; Rijk 1992; Travis 1994; Miner 1995; Green 1998; Hanauer 1996; Deventer 2001; Kruis 2001; Hawthorne 2012; Pica 2012). 
Figure 2. Risk of bias summary: review authors' judgements about each risk of bias item for each included study.

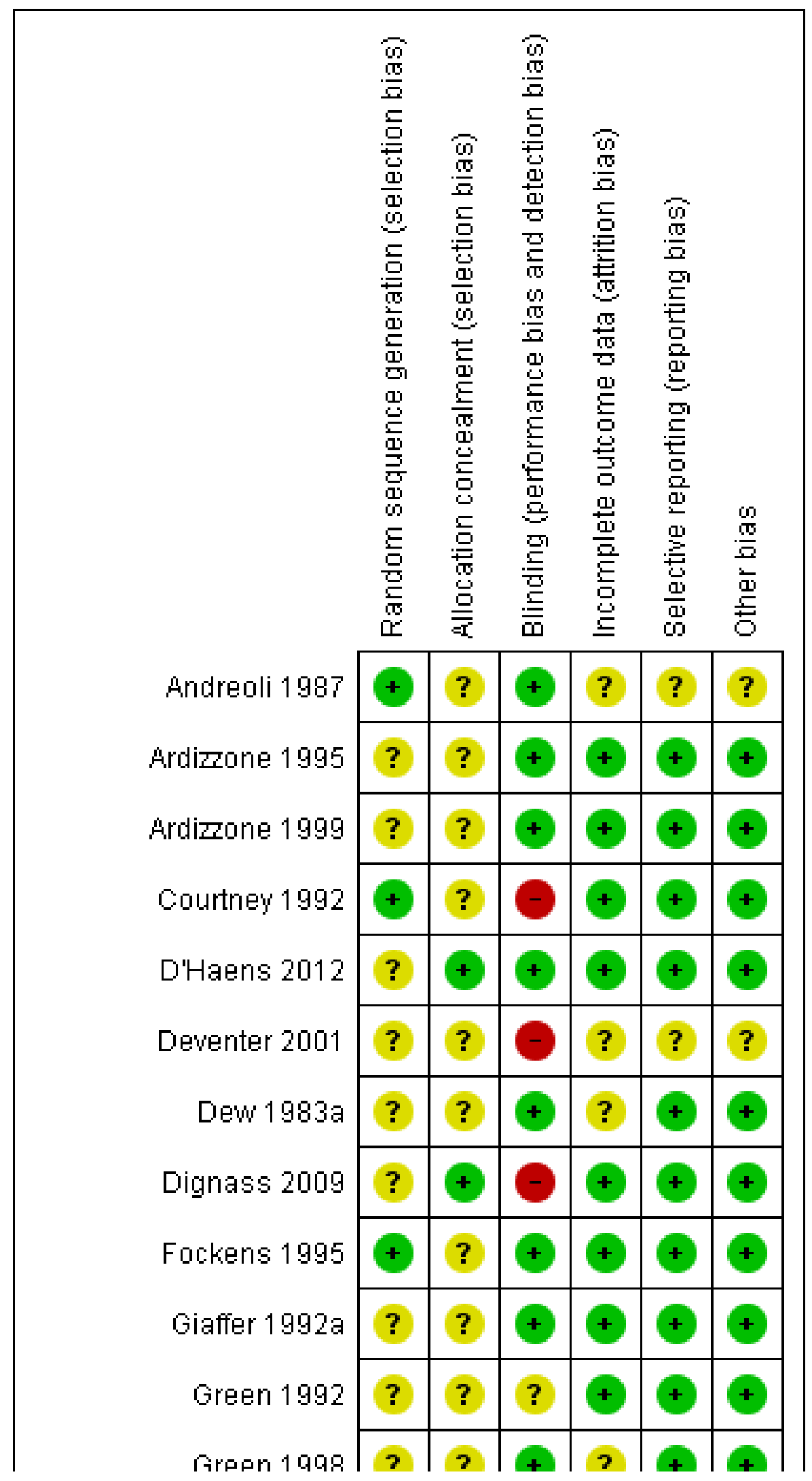


Figure 2. (Continued)

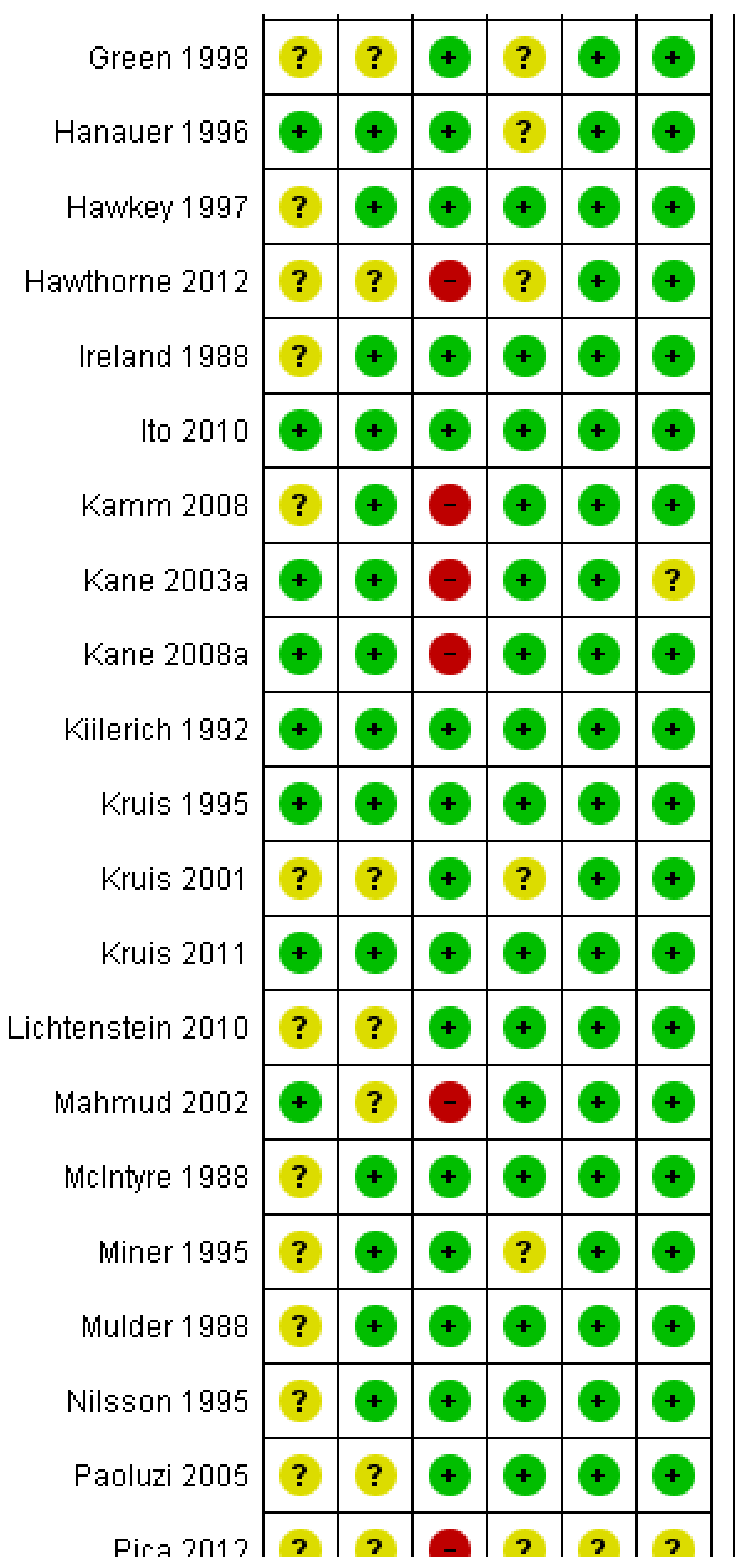


Figure 2. (Continued)

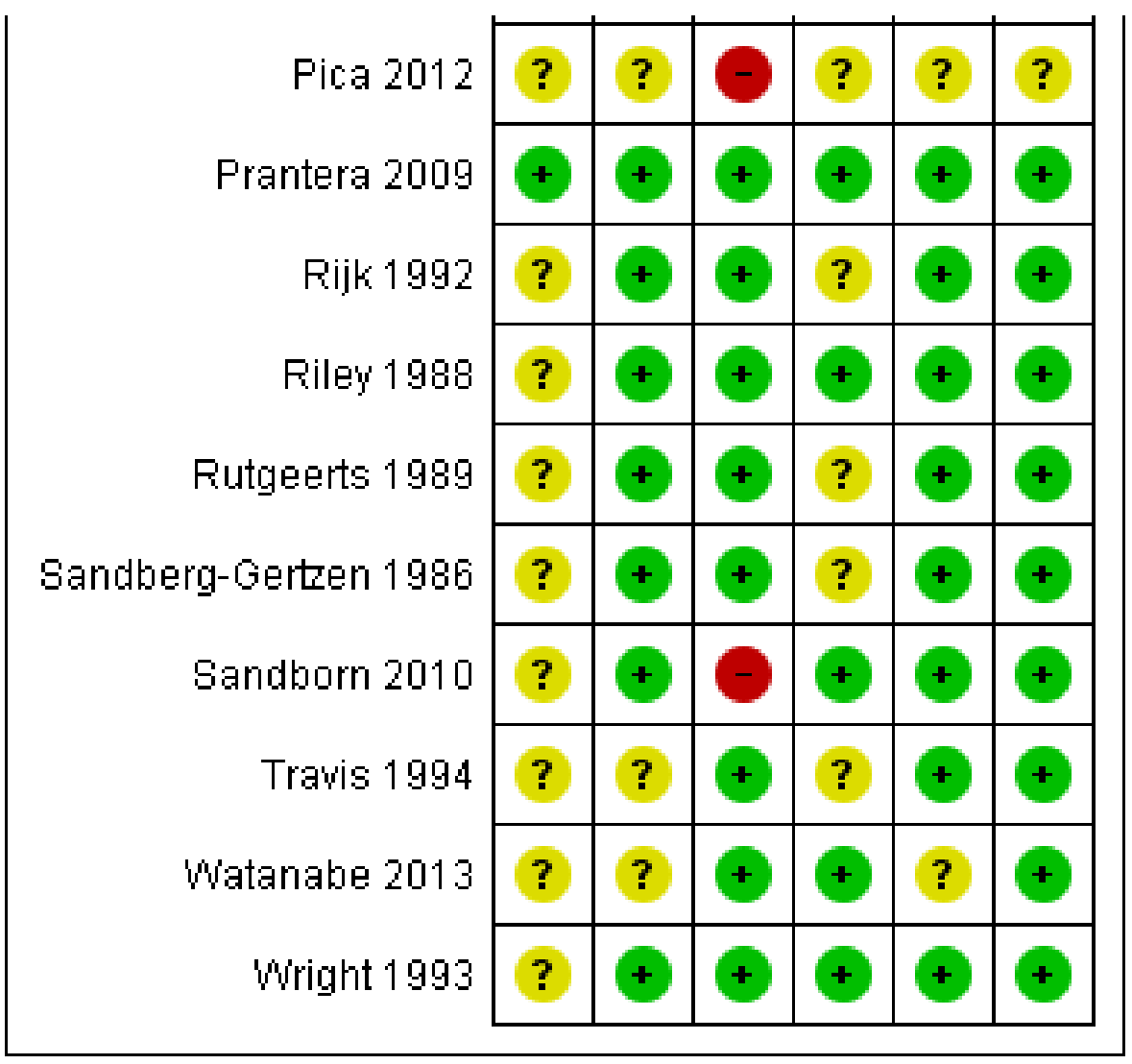

\section{Effects of interventions}

See: Summary of findings for the main comparison Oral 5-ASA versus placebo for maintenance of remission in ulcerative colitis; Summary of findings 2 Oral 5-ASA versus SASP for maintenance of remission in ulcerative colitis; Summary of findings 3 Once daily dosing versus conventional dosing for maintenance of remission in ulcerative colitis; Summary of findings 4 Oral 5-ASA versus comparator 5-ASA formulation for maintenance of remission in ulcerative colitis; Summary of findings 5 High dose oral 5-ASA versus low dose 5-ASA for maintenance of remission in ulcerative colitis

\section{EFFICACY}

\section{5-ASA versus Placebo}

Seven trials ( $\mathrm{n}=1298$ patients) reported treatment outcomes in terms of failure to maintain clinical or endoscopic remission (Sandberg-Gertzen 1986; Wright 1993; Miner 1995; Hanauer 1996; Hawkey 1997; Ardizzone 1999; Lichtenstein 2010). Forty-one per cent of 5-ASA patients relapsed compared to $58 \%$ of placebo patients. The pooled RR of failure to maintain clinical or endoscopic remission for all trials was $0.69\left(95 \% \mathrm{Cl} 0.62\right.$ to $0.77 ; \mathrm{I}^{2}=15 \%$; $\mathrm{P}$ $<0.00001$ ) using a fixed-effect model. There was a trend towards greater efficacy with higher doses of 5-ASA with a statistically significant benefit for the 1 to $1.9 \mathrm{~g} /$ day (RR $0.65 ; 95 \% \mathrm{Cl} 0.56$ to 0.76 ; $\mathrm{R}^{2}=0 \% ; \mathrm{P}<0.00001$ ) and the $\geq 2 \mathrm{~g} /$ day subgroups (RR $0.73 ; 95 \%$ $\mathrm{Cl} 0.60$ to $0.89 ; \mathrm{I}^{2}=71 \% ; \mathrm{P}=0.002$ ). The GRADE analysis indicated that the overall quality of the evidence for the primary outcome for the placebo-controlled studies (failure to maintain clinical or endoscopic remission) was high (See Summary of findings for the main comparison). The pooled RR was similar (RR 0.69; $95 \% \mathrm{Cl}$ 0.57 to 0.84 ) when calculated exclusively with those trials with endpoints at 12 months (Wright 1993; Miner 1995; Ardizzone 1999). Two of the trials involving olsalazine (Sandberg-Gertzen 1986; Wright 1993) had a pooled RR of 0.76 (95\% Cl 0.58 to 0.99). Two trials involving Asacol had a pooled RR of 0.73 ( $95 \% \mathrm{Cl} 0.60$ to 0.88 ).

\section{5-ASA versus Sulfasalazine}

Twelve trials involving a total of 1655 patients compared the efficacy of 5-ASA and SASP (Dew 1983a; Andreoli 1987; Ireland 1988; McIntyre 1988; Mulder 1988; Riley 1988; Rutgeerts 1989; Kiilerich 1992; Rijk 1992; Ardizzone 1995; Kruis 1995; Nilsson 1995). In 8 of the 11 studies the dose of SASP was limited to $2 \mathrm{~g} /$ day; in one trial the dose of SASP was $4 \mathrm{~g} /$ day; in one trial the mean dose of SASP was $2.7 \mathrm{~g} /$ day and ranged from 2.4 to $4.4 \mathrm{~g} /$ day (see Table of Included Studies). When the outcome of interest was defined as the failure to maintain clinical or endoscopic remission (withdrawals and relapses), SASP was significantly superior to 5-ASA. Forty-eight per cent of 5-ASA patients relapsed compared to $43 \%$ of SASP patients (RR $1.14,95 \% \mathrm{Cl} 1.03$ to $1.27 ; \mathrm{I}^{2}=17 \% \mathrm{P}=0.01$ ). The GRADE analysis indicated that the overall quality of the evidence for the primary outcome for the SASP-controlled studies (failure to maintain clinical or endoscopic remission) was high (See Summary of findings 2). The NNT value was found to be negative (-17), indicating that SASP has a certain degree of therapeutic superiority over the 5-ASA preparations. When the analysis was limited to those studies with endpoints at 12 months (Andreoli 1987; Mulder 1988; 
Riley 1988; Rutgeerts 1989; Kiilerich 1992; Rijk 1992; Nilsson 1995; Ardizzone 1995) there was no statistically significant difference between 5-ASA and SASP (RR 1.10; 95\% Cl 0.98 to 1.23). Similarly, when the analysis was limited to studies that did not use olsalazine (Dew 1983a; Andreoli 1987; McIntyre 1988; Mulder 1988; Riley 1988; Rutgeerts 1989; Ardizzone 1995) there was no statistically significant difference between 5-ASA and SASP (RR 1.08; 95\% Cl 0.92 to 1.26$)$.

Three trials involving Claversal $^{\circledR}$ (Andreoli 1987; Ardizzone 1995; Rutgeerts 1989) had a pooled RR of 1.15 ( $95 \% \mathrm{Cl} 0.95$ to 1.40$)$. When the five trials involving olsalazine (Ireland 1988; Kiilerich 1992; Kruis 1995; Nilsson 1995; Rijk 1992) were pooled, the resulting odds ratio was 1.20 ( $95 \% \mathrm{Cl} 1.04$ to 1.38$)$, thus demonstrating that SASP was significantly better than olsalazine for maintenance of remission.

\section{Once Daily Dosing versus Conventional Dosing}

Three trials ( $n=1871$ patients) reported treatment outcomes in terms of failure to maintain clinical or endoscopic remission at six months (Kane 2003a; Sandborn 2010; D'Haens 2012). There was no statistically significant difference in relapse rates at six months. Nineteen per cent of once daily patients relapsed compared to $18 \%$ of conventionally dosed patients (RR $1.02 ; 95 \% \mathrm{Cl} 0.85$ to 1.23 ). No statistically significant heterogeneity was detected for this comparison $(P=0.76,12=0 \%)$. None of the subgroup comparisons by formulation showed any differences in efficacy between once daily dosing and conventional dosing. However, only two formulations were evaluated in this pooled analysis. The GRADE analysis indicated that the overall quality of the evidence for the primary outcome (failure to maintain clinical or endoscopic remission at six months) for the studies comparing once daily with conventional dosing was low due to sparse data and a high risk of bias (single blind) in some studies in the pooled analysis (See Summary of findings 3 ).

Eight trials ( $n=3127$ patients) reported treatment outcomes in terms of failure to maintain clinical or endoscopic remission at 12 months (Kane 2008a; Kamm 2008; Dignass 2009; Prantera 2009; Sandborn 2010; Hawthorne 2012; Kruis 2011; Watanabe 2013). There was no statistically significant difference in relapse rates at 12 months. Twenty-nine per cent of once daily patients relapsed compared to $31 \%$ of conventionally dosed patients (RR $0.91 ; 95 \% \mathrm{Cl} 0.82$ to 1.01 ). No statistically significant heterogeneity was detected for this comparison $(P=0.26,12=22 \%)$. The subgroup comparison for Pentasa showed a statistically significant difference in favour of once daily dosing compared to conventional twice daily dosing (RR $0.75 ; 95 \% \mathrm{Cl} 0.60$ to 0.93 ). None of the other subgroup comparisons (by formulation) showed any differences in efficacy between once daily dosing and conventional dosing. The GRADE analysis indicated that the overall quality of the evidence for the primary outcome (failure to maintain clinical or endoscopic remission at 12 months) for the studies comparing once daily with conventional dosing was moderate due to a high risk of bias in some studies (open label and single blind) in the pooled analysis (See Summary of findings 3 ).

Eight trials $(n=2126)$ reported adherence with study medication at study endpoint (Kane 2003a; Kamm 2008; Kane 2008a; Dignass 2009; Prantera 2009; Kruis 2011; Hawthorne 2012; Watanabe 2013). Overall, $9.5 \%(101 / 1061)$ of patients in the once daily group failed to adhere to their medication regimen compared to $7.5 \%$ (80/1065) of patients in the conventional dosing group. The pooled RR using a random-effects model was $1.18(95 \% \mathrm{Cl} 0.69$ to 2.03$)$ showing no statistically significant difference in medication adherence between once daily dosing and conventional dosing at study endpoint ( 6 months for Kane 2003a and 12 months for the other studies in the pooled analysis; $\mathrm{P}=0.55)$. Statistically significant heterogeneity was detected for this comparison $(P=0.009,12=$ $63 \%)$. The heterogeneity appears to be a result of the inclusion of two specific trials (Kamm 2008; Hawthorne 2012). Kamm 2008 reported a significantly higher compliance rate of $99.6 \%$ in the twice daily dosing group compared to $93.3 \%$ in the once daily group. Hawthorne 2012 reported a significantly higher compliance rate of $97.1 \%$ in the once daily dosing group compared to $85.5 \%$ in the three times daily dosing group. To investigate if these studies were the source of the heterogeneity the analysis was repeated excluding these trials. The pooled analysis of the ITT population now included 6 studies and 1462 patients (Kane 2003a; Kane 2008a; Dignass 2009; Prantera 2009; Kruis 2011; Watanabe 2013). Overall, $11.2 \%(83 / 739)$ of patients in the once daily group failed to adhere to their medication regimen compared to $8.7 \%(63 / 723)$ of patients in the conventional dosing group. The pooled RR using a fixedeffect model was 1.22 ( $95 \% \mathrm{Cl} 0.91$ to 1.64 ) showing no statistically significant difference in medication adherence between once daily dosing and conventional dosing at study endpoint $(P=0.18)$. No statistically significant heterogeneity was detected for this comparison $\left(P=0.55 ; 1^{2}=0 \%\right)$. The GRADE analysis indicated that the overall quality of the evidence for the adherence outcome was moderate due to sparse data (See Summary of findings 3).

\section{5-ASA versus Comparator 5-ASA Formulation}

Six studies ( $\mathrm{n}=707$ patients) reported treatment outcomes in terms of the failure to maintain clinical or endoscopic remission at 12 months (Courtney 1992; Green 1998; Deventer 2001; Kruis 2001; Mahmud 2002; Ito 2010). The overall pooled RR showed no statistically significant difference in relapse between various formulations of 5-ASA (including Balsalazide, Pentasa and Olsalazine) and comparator formulations of 5-ASA (including Asacol and Salofalk). Forty-four per cent of patients in the 5ASA group relapsed compared to $41 \%$ of patients in the 5-ASA comparator group. The pooled RR of relapse was $1.08(95 \% \mathrm{Cl}$ 0.91 to $1.28 ; I^{2}=31 \% ; P=0.37$ ) using a fixed-effect model. The GRADE analysis indicated that the overall quality of the evidence for the primary outcome (failure to maintain clinical or endoscopic remission) was low due to sparse data (300 events) and a high risk of bias (lack of blinding) in two studies in the pooled analysis (See Summary of findings 4).

\section{5-ASA Dose Ranging}

Several randomized trials have looked at dose-ranging for various formulations of 5-ASA including Asacol, Balsalazide, Olsalazine, Salofalk, and Pentasa. Four studies examined the efficacy of various doses of Asacol for maintenance of clinical or endoscopic remission (Hanauer 1996; Deventer 2001; Paoluzi 2005; Pica 2012). Pica 2012 found no statistically significant difference in efficacy between Asacol $4.8 \mathrm{~g} /$ day compared to $2.4 \mathrm{~g} /$ day. Twenty-nine per cent of patients in the Asacol $4.8 \mathrm{~g} /$ day group relapsed compared to $36 \%$ in the $2.4 \mathrm{~g}$ /day group (112 patients; RR $0.80 ; 95 \% \mathrm{Cl} 0.46$ to 1.38 ). A GRADE analysis indicated that the overall quality of the evidence for the primary outcome was very low due to very sparse data and risk of bias. Paoluzi 2005 found no statistically significant difference in efficacy between Asacol $2.4 \mathrm{~g} /$ day compared to $1.2 \mathrm{~g} /$ day. 
Seventy per cent of patients in the Asacol $2.4 \mathrm{~g} /$ day group relapsed compared to $74 \%$ in the $1.2 \mathrm{~g}$ /day group (156 patients; RR 0.95; $95 \% \mathrm{Cl} 0.78$ to 1.16 ). Deventer 2001 found no statistically significant difference in efficacy between Asacol $3.2 \mathrm{~g}$ /day compared to $2 \mathrm{~g} /$ day. Fifty-one per cent of patients in the Asacol $3.2 \mathrm{~g} /$ day group relapsed compared to $48 \%$ of patients in the $2 \mathrm{~g}$ /day group (262 patients; RR 1.07; 95\% Cl 0.83 to 1.37). Hanauer 1996 found no statistically significant difference in efficacy between Asacol $1.6 \mathrm{~g} /$ day compared to $0.8 \mathrm{~g} /$ day. Fifty-six per cent of patients relapsed in both dose groups (177 patients; RR 1.01; $95 \% \mathrm{Cl} 0.78$ to 1.32).

Three studies examined the efficacy of various doses of Balsalazide for maintenance of clinical or endoscopic remission (Giaffer 1992a; Green 1992; Kruis 2001). Two of these studies compared Balsalazide $6 \mathrm{~g} /$ day to $3 \mathrm{~g} /$ day (Green 1992; Kruis 2001). The pooled analysis showed no statistically significant difference in efficacy between Balsalazide $6 \mathrm{~g} /$ day and $3 \mathrm{~g} /$ day. Twenty-three per cent of patients in the $6 \mathrm{~g}$ /day group relapsed (216 patients; RR $0.72 ; 95 \% \mathrm{Cl}$ 0.46 to 1.13 ). However, these results should be interpreted with caution as statistically significant heterogeneity was detected for this comparison $(P=0.007 ; 12=86 \%)$. A GRADE analysis indicated that the overall quality of the evidence for the primary outcome was very low due to sparse data, very wide confidence intervals and inconsistency. Giaffer 1992a compared Balsalazide $4 \mathrm{~g} /$ day to $2 \mathrm{~g} /$ day and found a statistically significant difference favouring the 4 $\mathrm{g} /$ day dose group. Thirty-seven per cent of patients in the $4 \mathrm{~g}$ /day Balsalazide group relapsed compared to $55 \%$ of patients in the 2 g/day group (133 patients; RR $0.66 ; 95 \% \mathrm{Cl} 0.45$ to 0.97 ). A GRADE analysis indicated that the overall quality of the evidence for the primary outcome was moderate due to sparse data.

Travis 1994 found no statistically significant difference in efficacy between Olsalazine $2 \mathrm{~g}$ /day and $1 \mathrm{~g}$ /day. Forty per cent of patients in both dose groups relapsed (127 patients; RR 1.01; $95 \% \mathrm{Cl} 0,66$ to 1.54). Kruis 2011 found a statistically significant difference between Salofalk granules $3 \mathrm{~g} /$ day and $1.5 \mathrm{~g} /$ day. Twenty-five per cent of patients in the Salofalk $3 \mathrm{~g} /$ day group relapsed compared to $39 \%$ of patients in the $1.5 \mathrm{~g} /$ day group (429 patients; RR 0.65; 95\% Cl 0.49 to 0.86 ). Fockens 1995 found no statistically significant difference in efficacy between Pentasa $3.0 \mathrm{~g} / \mathrm{day}$ and $1.5 \mathrm{~g} /$ day. Twenty-eight per cent of patients in the $3.0 \mathrm{~g} /$ day group relapsed compared to $38 \%$ in the $1.5 \mathrm{~g}$ /day group (169 patients; RR $0.74 ; 95 \% \mathrm{Cl} 0.48$ to 1.15 ). A GRADE analysis indicated that the overall quality of the evidence for the primary outcome was moderate due to sparse data.

\section{SAFETY}

Three different outcome measures were used to evaluate the safety and clinical utility of 5-ASA relative to placebo and SASP: the number of patients with adverse events, the number of patients withdrawn due to adverse events, and the total number of patients excluded or withdrawn before completion of the study. Since many studies only reported the total number of adverse events rather than the number of patients who experienced an event, we were often unable to include such data in the analysis.

\section{5-ASA versus Placebo}

Four studies ( $\mathrm{n}=962$ patients) reported the proportion of patients who experienced at least one adverse event (Wright 1993; Miner 1995; Hanauer 1996; Lichtenstein 2010). There was no statistically significant difference in the incidence of adverse events between 5-ASA and placebo patients. Forty-one per cent of 5-ASA patients experienced at least one adverse event compared to $34 \%$ of placebo patients (RR $0.98 ; 95 \% \mathrm{Cl} 0.69$ to $1.39 ; \mathrm{P}=0.91$ ). Statistically significant heterogeneity was detected for this comparison $(P=$ $\left.0.04 ; 1^{2}=60 \%\right)$. The heterogeneity appears to be a result of the inclusion of one specific trial (Wright 1993). Wright 1993 reported a significantly higher adverse event rate in the 5-ASA group compared to placebo. This was mostly due to a high rate of olsalazinerelated diarrhea in the 5-ASA group. To investigate if this study was the source of the heterogeneity the analysis was repeated excluding this trial. The pooled analysis of the ITT population now included 3 studies and 861 patients (Miner 1995; Hanauer 1996; Lichtenstein 2010). There was no statistically significant difference in the incidence of adverse events between 5-ASA and placebo patients. Overall, $42 \%$ of 5-ASA patients experienced at least one adverse event compared to $39 \%$ of placebo patients (RR 0.94; $95 \% \mathrm{Cl} 0.77$ to 1.15 ). No statistically significant heterogeneity was detected for this comparison $(P=0.31 ; 12=17 \%)$. The GRADE analysis indicated that the overall quality of the evidence for this outcome for the placebo-controlled studies (the proportion of patients who experienced at least one adverse event) was moderate low due to sparse data (See Summary of findings for the main comparison).

Six studies ( $\mathrm{n}=1197$ patients) reported the proportion of patients withdrawn due to adverse events (Wright 1993; Miner 1995; Hanauer 1996; Hawkey 1997; Ardizzone 1999; Lichtenstein 2010). There was no statistically significant difference in withdrawal due to adverse events between 5-ASA and placebo patients. Withdrawals due to adverse events were reported for $5 \%$ of 5-ASA patients compared to $4 \%$ of placebo patients (RR $1.34 ; 95 \% \mathrm{Cl} 0.78$ to 2.30). Statistically significant heterogeneity was detected for this comparison $(P=0.10 ; 12=44 \%)$. Again the heterogeneity appears to be a result of the inclusion of one specific trial (Wright 1993). To investigate if this study was the source of the heterogeneity the analysis was repeated excluding this trial. The pooled analysis of the ITT population now included 5 studies and 1096 patients (Miner 1995; Hanauer 1996; Hawkey 1997; Ardizzone 1999; Lichtenstein 2010). There was no statistically significant difference in withdrawal due to adverse events between 5-ASA and placebo patients. Overall, $3 \%$ of 5-ASA patients withdrew due to adverse events compared to $4 \%$ of placebo patients in the conventional dosing group (RR $0.86 ; 95 \% \mathrm{Cl} 0.46$ to 1.63 ). No statistically significant heterogeneity was detected for this comparison $\left(P=0.48 ; 1^{2}=\right.$ $0 \%$ ). The GRADE analysis indicated that the overall quality of the evidence for this outcome for the placebo-controlled studies (the proportion of patients withdrawn due to adverse events) was moderate due to sparse data (See Summary of findings for the main comparison).

Five studies ( $n=1175$ patients) reported the proportion of patients excluded or withdrawn after entry (Wright 1993; Miner 1995; Hanauer 1996; Ardizzone 1999; Lichtenstein 2010). There was no statistically significant difference in the proportion of patients withdrawn or excluded after entry. Nineteen per cent of 5-ASA patients were withdrawn or excluded after entry compared to $18 \%$ of placebo patients (RR $1.13 ; 95 \% \mathrm{Cl} 0.88$ to $1.44 ; \mathrm{I}^{2}=11 \%$ ).The GRADE analysis indicated that the overall quality of the evidence for this outcome for the placebo-controlled studies (the proportion of patients withdrawn or excluded after entry) was moderate due to sparse data (202 events; See Summary of findings table 1). 
Commonly reported adverse events in the placebo-controlled trials included: headache (Miner 1995; Hanauer 1996; Hawkey 1997; Lichtenstein 2010), nausea (Miner 1995; Hawkey 1997; Lichtenstein 2010), abdominal pain (Miner 1995; Hanauer 1996; Ardizzone 1999; Lichtenstein 2010), dyspepsia (Miner 1995), bloating (Ardizzone 1999), flu syndrome (Hanauer 1996) rhinitis (Hanauer 1996) and nasopharyngitis (Lichtenstein 2010). Diarrhea was reported in one study involving olsalazine (Wright 1993), two Asacol studies (Hanauer 1996; Ardizzone 1999) and one study of Apriso (Lichtenstein 2010).

\section{5-ASA versus Sulfasalazine}

Seven studies ( $\mathrm{n}=1138$ patients) reported the proportion of patients who experienced at least one adverse event (Andreoli 1987; Ireland 1988; Mclntyre 1988; Mulder 1988; Rutgeerts 1989; Kruis 1995; Nilsson 1995). There was no statistically significant difference in the incidence of adverse events. Sixteen per cent of 5ASA patients and SASP patients experienced at least one adverse event (RR $1.07 ; 95 \% \mathrm{Cl} 0.82$ to 1.40 ). No statistically significant heterogeneity was detected for this comparison $\left(P=0.12 ; 1^{2}=\right.$ $41 \%)$. A GRADE analysis indicated that the overall quality of the evidence for this outcome for the SASP-controlled studies (the proportion of patients who experienced at least one adverse event) was moderate low due to sparse data (See Summary of findings 2). Three olsalazine trials including 634 patients (Ireland 1988; Kruis 1995; Nilsson 1995) that were homogeneous $(12=0 \%)$ had a pooled odds ratio of $1.27(95 \% \mathrm{Cl}, 0.92$ to 1.76$)$.

Ten studies ( $\mathrm{n}=1585$ patients) reported the proportion of patients withdrawn due to adverse events (Ireland 1988; Mclntyre 1988; Mulder 1988; Riley 1988; Rutgeerts 1989; Kiilerich 1992; Rijk 1992; Ardizzone 1995; Kruis 1995; Nilsson 1995). There was no statistically significant difference in withdrawals due to adverse events. Seven per cent of 5-ASA patients were withdrawn due to adverse events compared to $5 \%$ of SASP patients (RR $1.27 ; 95 \% \mathrm{Cl} 0.87$ to 1.87 ). No statistically significant heterogeneity was detected for this comparison ( $\left.P=0.72 ; 1^{2}=0 \%\right)$. In five olsalazine trials including 906 patients (Ireland 1988, Kruis 1995, Nilsson 1995, Kiilerich 1992, Rijk 1992), $9.2 \%$ of those receiving olsalazine and $6.2 \%$ of those receiving SASP were withdrawn because of adverse events (RR 1.61; $95 \% \mathrm{Cl}, 1.01$ to 2.56$)$. A GRADE analysis indicated that the overall quality of the evidence for this outcome for the SASP-controlled studies (the proportion of patients withdrawn due to adverse events) was moderate low due to sparse data (See Summary of findings 2). The results from two Claversal $^{\circledR}$ trials including 422 patients (Ardizzone 1995; Rutgeerts 1989) were not statistically significant (RR $1.10 ; 95 \% \mathrm{Cl}, 0.48$ to 2.54 ).

Nine studies involving 1497 patients (Ireland 1988; McIntyre 1988; Mulder 1988; Riley 1988; Rutgeerts 1989; Kiilerich 1992; Rijk 1992; Kruis 1995; Nilsson 1995) reported the proportion of patients excluded or withdrawn after entry (excluding relapses). Nineteen per cent of 5-ASA patients were excluded or withdrawn after entry compared to $15 \%$ of SASP patients (RR $1.30 ; 95 \% \mathrm{Cl} 1.04$ to 1.63 ). No statistically significant heterogeneity was detected for this comparison $(P=0.18 ; 12=29 \%)$. Withdrawals or exclusions after entry were significantly higher in five olsalazine trials (Ireland 1988; Kiilerich 1992; Rijk 1992; Kruis 1995; Nilsson 1995) involving 906 patients. Seventeen per cent of olsalazine patients were withdrawn or excluded after entry compared to $12 \%$ of SASP patients (RR 1.51; $95 \% \mathrm{Cl} 1.09$ to 2.08 ).
Commonly reported adverse events in the SASP-controlled trials included: headache (McIntyre 1988; Riley 1988; Kruis 1995), anorexia or appetite loss (Riley 1988; Rutgeerts 1989) nausea (McIntyre 1988; Riley 1988; Rutgeerts 1989; Kiilerich 1992), vomiting (Riley 1988; Rutgeerts 1989; Nilsson 1995), abdominal pain (Ireland 1988; Rutgeerts 1989; Kiilerich 1992; Nilsson 1995), dyspepsia (Ireland 1988; Riley 1988; Kiilerich 1992; Rijk 1992), excessive flatus (McIntyre 1988), bloating (Rutgeerts 1989), urticaria (Kiilerich 1992; Ardizzone 1995) and rash (McIntyre 1988; Mulder 1988; Rijk 1992; Kruis 1995; Nilsson 1995). Diarrhea was reported in five studies involving Olsalazine (Ireland 1988; Kiilerich 1992; Rijk 1992; Kruis 1995; Nilsson 1995), and in two studies involving Claversal (Rutgeerts 1989; Ardizzone 1995).

\section{Once Daily Dosing versus Conventional Dosing}

Six studies ( $n=2714$ patients) reported the proportion of patients who experienced at least one adverse event (Kamm 2008; Dignass 2009; Prantera 2009; Kruis 2011; D'Haens 2012; Watanabe 2013). There was no statistically significant difference in the incidence of adverse events. Approximately $45 \%$ of once daily and conventionally dosed patients experienced at least one adverse event (RR $1.00 ; 95 \% \mathrm{Cl} 0.92$ to 1.08 ). No statistically significant heterogeneity was detected for this comparison $\left(P=0.43 ; 1^{2}=\right.$ $0 \%)$. Seven studies ( $n=3737$ patients) reported the proportion of patients who were withdrawn due to adverse events (Kamm 2008; Dignass 2009; Prantera 2009; Sandborn 2010; Kruis 2011; D'Haens 2012; Watanabe 2013). There was no statistically significant difference in withdrawal due to adverse events. Withdrawals due to adverse events were $1.9 \%(36 / 1858)$ in the once daily group compared to $1.5 \%(28 / 1879)$ in the conventionally dosed group (RR $1.31 ; 95 \% \mathrm{Cl} 0.80$ to 2.13$)$. No statistically significant heterogeneity was detected for this comparison $\left(P=0.42 ; 1^{2}=1 \%\right)$. Seven studies ( $n=3737$ patients) reported the proportion of patients who were excluded or withdrawn after entry (Kamm 2008; Dignass 2009; Prantera 2009; Sandborn 2010; Kruis 2011; D'Haens 2012; Watanabe 2013). There was no statistically significant difference in exclusions or withdrawals after entry. Approximately $15 \%$ of once daily and conventionally dosed patients were excluded or withdrawn after entry (RR $0.99 ; 95 \% \mathrm{Cl} 0.85$ to 1.15 ). No statistically significant heterogeneity was detected for this comparison $(P=0.48 ; 12=0 \%)$.

The most common adverse events reported in the trials assessing once daily dosing included flatulence (Dignass 2009; Prantera 2009), dyspepsia (D'Haens 2012), abdominal pain (Kamm 2008; Dignass 2009; Prantera 2009; D'Haens 2012; Watanabe 2013), nausea (Prantera 2009), diarrhea (Dignass 2009; Prantera 2009; Watanabe 2013), headache (Kamm 2008; Prantera 2009; D'Haens 2012), nasopharyngitis (Kamm 2008; Dignass 2009; Watanabe 2013), inflammation of the upper respiratory tract (Watanabe 2013), gastroenteritis (Watanabe 2013), dental caries (Watanabe 2013), and worsening ulcerative colitis (Kamm 2008; Prantera 2009; Kruis 2011; D'Haens 2012).

\section{5-ASA versus Comparator 5-ASA Formulation}

Four studies ( $\mathrm{n}=357$ patients) reported the proportion of patients who experienced at least one adverse event (Green 1998; Kruis 2001; Mahmud 2002; Ito 2010). There was no statistically significant difference in the incidence of adverse events between various formulations of 5-ASA (including Balsalazide, Pentasa and Olsalazine) and comparator formulations of 5-ASA (including 
Asacol and Salofalk). Sixty-four per cent of patients in the 5-ASA group experienced at least one adverse event compared to $69 \%$ of patients in the 5-ASA comparator group (RR $0.94 ; 95 \% \mathrm{Cl} 0.83$ to 1.07). No statistically significant heterogeneity was detected for this comparison $\left(\mathrm{P}=0.35 ; \mathrm{I}^{2}=8 \%\right)$.

Five studies ( $n=457$ patients) reported the proportion of patients who were withdrawn due to adverse events (Courtney 1992; Green 1998; Kruis 2001; Mahmud 2002; Ito 2010). There was no statistically significant difference in withdrawal due to adverse events between various formulations of 5-ASA (including Balsalazide, Pentasa and Olsalazine) and comparator formulations of 5-ASA (including Asacol and Salofalk). Six per cent of patients in the 5-ASA group withdrew due to adverse events compared to $4 \%$ of patients in the 5-ASA comparator group (RR $1.25 ; 95 \% \mathrm{Cl} 0.56$ to 2.78). No statistically significant heterogeneity was detected for this comparison $\left(P=0.76 ; 1^{2}=0 \%\right)$.

Five studies ( $n=457$ patients) reported the proportion of patients who were excluded or withdrawn after entry (Courtney 1992; Green 1998; Kruis 2001; Mahmud 2002; Ito 2010). There was no statistically significant difference in exclusions or withdrawals after entry between various formulations of 5-ASA (including Balsalazide, Pentasa and Olsalazine) and comparator formulations of 5-ASA (including Asacol and Salofalk). Twenty-eight per cent of patients in the 5-ASA group were excluded or withdrawn after entry compared to $22 \%$ of patients in the 5 -ASA comparator group (RR $1.23 ; 95 \% \mathrm{Cl}$ 0.90 to 1.70$)$. No statistically significant heterogeneity was detected for this comparison $\left(P=0.52 ; 1^{2}=0 \%\right)$.

The most common adverse events reported in these trials included dyspepsia (Mahmud 2002), abdominal pain (Courtney 1992; Green 1998; Kruis 2001; Mahmud 2002), nausea (Courtney 1992; Kruis 2001; Mahmud 2002), distension (Mahmud 2002) diarrhea (Courtney 1992; Green 1998; Kruis 2001; Mahmud 2002; Ito 2010), headache (Green 1998; Kruis 2001), nasopharyngitis or respiratory infections (Green 1998; Ito 2010), flu-like disorder (Green 1998) and rash (Courtney 1992).

\section{5-ASA Dose Ranging}

Five dose-ranging studies reported the proportion of patients who experienced at least one adverse event (Travis 1994; Hanauer 1996; Kruis 2001; Paoluzi 2005; Kruis 2011). Kruis 2011 found a statistically significant difference in the proportion of patients who experienced at least one adverse event between Salofalk $3 \mathrm{~g} /$ day and $1.5 \mathrm{~g} /$ day both dosed once daily. Forty-one per cent of patients in the $3 \mathrm{~g} /$ day group experienced at least one adverse event compared to $55 \%$ of patients in the $1.5 \mathrm{~g} /$ day group (429 patients; RR 0.74; $95 \% \mathrm{Cl} 0.61$ to 0.91 ). Hanauer 1996 found a statistically significant difference in the proportion of patients who experienced at least one adverse event between Asacol $1.6 \mathrm{~g} /$ day and $0.8 \mathrm{~g} /$ day. Forty-one per cent of patients in the Asacol $1.6 \mathrm{~g} /$ day group experienced at least one adverse event compared to $22 \%$ of patients in the $0.8 \mathrm{~g} /$ day group (177 patients; RR $1.86 ; 95 \% \mathrm{Cl} 1.18$ to 2.95 ). No statistically significant differences in the incidence of adverse events were found between Asacol $2.4 \mathrm{~g} /$ day and $1.2 \mathrm{~g} /$ day (RR 2.85; 95\% Cl 0.12 to 68.95), Balsalazide $6.0 \mathrm{~g} /$ day and $3.0 \mathrm{~g} /$ day (RR 1.40; $95 \% \mathrm{Cl} 0.88$ to 2.24), and Olsalazine $2.0 \mathrm{~g} /$ day and $1.0 \mathrm{~g} /$ day (RR $1.37 ; 95 \% \mathrm{Cl}$ 0.94 to 1.99 ).

Seven dose-ranging studies reported the proportion of patients who were withdrawn due to adverse events (Giaffer 1992a; Green
1992; Fockens 1995; Hanauer 1996; Kruis 2001; Paoluzi 2005; Kruis 2011). No statistically significant differences in withdrawal due to adverse events were found between Asacol $2.4 \mathrm{~g} /$ day and $1.2 \mathrm{~g} /$ day (1 study, 156 patients, RR 2.85; 95\% Cl 0.12 to 68.95); Asacol $1.6 \mathrm{~g} /$ day and $0.8 \mathrm{~g} /$ day (1 study, 177 patients, RR $0.34 ; 95 \% \mathrm{Cl} 0.04$ to 3.25); Balsalazide $6.0 \mathrm{~g} /$ day and $3.0 \mathrm{~g} /$ day (2 studies, 196 patients, RR 0.59; $95 \% \mathrm{Cl} 0.21$ to 1.70 ); Balsalazide $4.0 \mathrm{~g} /$ day and $2.0 \mathrm{~g} /$ day (1 study, 133 patients, RR 1.43; $95 \%$ Cl 0.54 to 3.80); Salofalk 3.0 g/day and $1.5 \mathrm{~g} /$ day (1 study, 429 patients, RR $0.98 ; 95 \% \mathrm{Cl} 0.29$ to 3.33 ); and Pentasa $3.0 \mathrm{~g} /$ day and $1.5 \mathrm{~g} /$ day (1 study, 169 patients, RR 1.06; $95 \% \mathrm{Cl} 0.07$ to 16.69 ).

Eight dose-ranging studies reported the proportion of patients who were excluded or withdrawn after entry (Giaffer 1992a; Green 1992; Travis 1994; Fockens 1995; Hanauer 1996; Kruis 2001; Paoluzi 2005; Kruis 2011). A statistically significant difference was found between Balsalazide $6.0 \mathrm{~g} /$ day and $3.0 \mathrm{~g} /$ day (2 studies, 196 patients, RR 0.47; $95 \% \mathrm{Cl} 0.26$ to 0.84 ) and between Salofalk $3 \mathrm{~g} /$ day and $1.5 \mathrm{~g} /$ day (1 study, 429 patients, RR $0.66 ; 95 \% \mathrm{Cl} 0.46$ to 0.93 ). No statistically significant differences were found in exclusions or withdrawals after entry between Asacol $2.4 \mathrm{~g} /$ day and $1.2 \mathrm{~g} /$ day (1 study, 156 patients, RR 0.95; 95\% Cl 0.38 to 2.40 ); Asacol $1.6 \mathrm{~g} /$ day and $0.8 \mathrm{~g} /$ day (1 study, 177 patients, RR $1.23 ; 95 \% \mathrm{Cl} 0.80$ to 1.90 ); Balsalazide $4.0 \mathrm{~g} /$ day and $2.0 \mathrm{~g} /$ day ( 1 study, 133 patients, RR 1.27; 95\% Cl 0.77 to 2.12); Olsalazine $2.0 \mathrm{~g} /$ day and $1.0 \mathrm{~g} /$ day (1 study, 127 patients, RR 1.75; $95 \% \mathrm{Cl} 0.83$ to 3.70 ); and Pentasa $3.0 \mathrm{~g} /$ day and $1.5 \mathrm{~g} /$ day (1 study, 169 patients, RR 0.83 ; $95 \% \mathrm{Cl} 0.44$ to 1.55 ).

\section{DISCUSSION}

This updated systematic review has largely confirmed the results of previous meta-analyses (Sutherland 1993; Sutherland 1997; Sutherland 2006; Feagan 2012), but differs from the previous work in a variety of aspects. The updated review includes 41 studies and 8928 patients which greatly increases statistical power. Different quality assessment criteria (i.e. Cochrane risk of bias tool) were also used. The current review also utilized the GRADE criteria (Guyatt 2008; Schünemann 2011). to assess the overall quality of the data obtained from the randomized studies included in the review.

Unfortunately, there are limitations to making general conclusions. Almost every study utilized a unique clinical or endoscopic index. Unlike Crohn's disease, the lack of standard indices in ulcerative colitis prevented the collection of consistent treatment efficacy data and makes comparisons across clinical studies difficult. As well, several studies failed to specify the treatment arm to which certain excluded patients were initially randomized. Despite these and other common factors that must be considered when interpreting meta-analyses, the data provided strong evidence that pointed towards a number of conclusions.

The effectiveness of oral 5-ASA preparations for maintenance of remission in quiescent ulcerative colitis was confirmed. Oral 5-ASA is superior to placebo for maintenance of remission in ulcerative colitis. The quality of the placebo-controlled trials was assessed using the Cochrane risk of bias tool and the possibility of bias was rated as low for these studies. The outcome failure to maintain clinical or endoscopic remission was rated as 'high' using the GRADE criteria indicating that further research is very unlikely to change our confidence in the point estimates of effect. There was a trend towards greater efficacy with higher doses of 5-ASA with a statistically significant benefit for the 1 to $1.9 \mathrm{~g} /$ day and the $\geq 2 \mathrm{~g} /$ day dosage groups. 
An interesting result was that SASP was found to have a modest, but statistically significant benefit over 5-ASA. The quality of the SASP-controlled trials was assessed using the Cochrane risk of bias tool and the possibility of bias was rated as low for these studies. The outcome failure to maintain clinical or endoscopic remission was rated as 'high' using the GRADE criteria indicating that further research is unlikely to change our confidence in the point estimates of effect. When the pooled analysis was limited to trials with endpoints at 12 months the difference was no longer statistically significant. Nevertheless, certain limitations may have resulted from having combined all trials regardless of whether relapse was defined in terms of clinical or endoscopic criteria. It is possible that the "superiority" of SASP over 5-ASA is a reflection of the intention-to-treat analysis which was employed. This technique considers all patients who received the medication and penalizes medications with high drop-out rates (for example olsalazine). A "per protocol" analysis which includes those patients who are compliant and who tolerate the medication might not support a "superiority" claim.

When data for maintenance therapy were subgrouped according to the specific 5-ASA preparation, olsalazine was observed to be significantly inferior to SASP. Firm conclusions regarding other preparations, which have generally been subject to less rigorous clinical evaluation, could not be surmised. In the case of olsalazine, it appeared that the reduced efficacy was influenced by the significantly higher proportions of withdrawals due to adverse events and total exclusions or withdrawals of patients receiving olsalazine compared to those receiving SASP. In fact, if the analysis of efficacy was restricted to relapses as treatment failures, excluding withdrawals for other reasons, there was no significant difference between olsalazine and SASP (data not shown). The difference may also be related to a misclassification bias in which patients who developed diarrhea were falsely classified as treatment relapses rather than having experienced adverse events.

The overall superiority of SASP over 5-ASA in maintenance therapy may also be attributable to certain pharmacological properties of SASP, including potential therapeutic effects of the sulfapyridine moiety, that are not observed with other 5-ASA delivery systems. The mechanisms of action of SASP and its metabolites have been reviewed by Greenfield 1993.

It was apparent that the newer 5-ASA preparations were not entirely innocent of adverse effects in a number of patients. However, the incidence of adverse events and withdrawals due to the 5ASA formulations did not significantly differ from that associated with placebo. There was also no apparent difference between the number of adverse events caused by SASP and 5-ASA. It should be noted that there may have been a bias in favour of SASP since many of the studies involved patients who were known to have tolerated SASP in the past. This may have minimized SASP-related adverse events in these trials.

In contrast to these results, olsalazine was associated with a significantly higher proportion of withdrawals due to adverse events relative to SASP. The most common adverse event attributed to olsalazine was diarrhea, an effect previously observed to occur in approximately $10 \%$ of patients receiving the drug (Ireland $1988 \mathrm{~b})$. It has been suggested that protocol alterations may reduce withdrawal rates in future trials since it has been reported that encouraging patients to take olsalazine with meals appears to reduce the incidence of diarrhea to approximately three per cent of patients (Jarnerot 1996). However, four of the five olsalazine-SASP trials (Kiilerich 1992, Kruis 1995, Nilsson 1995, Rijk 1992) reported that such recommendations were in fact made.

This meta-analysis indicates that mesalamine administered once daily is as effective as conventional dosing (twice or three times daily) for maintenance of remission over 6 and 12 months periods in patients with quiescent ulcerative colitis. The pooled analyses showed no significant differences between once daily and conventional dosing for maintenance of remission at 6 months (RR $1.02 ; 95 \% \mathrm{Cl} 0.85$ to $1.23 ; \mathrm{P}=0.82$ ) or 12 months (RR $0.91 ; 95 \% \mathrm{Cl} 0.82$ to $1.01 ; \mathrm{P}=0.09$ ). With the exception of Pentasa ${ }^{\circledR}$, subgroup analyses by drug formulation showed no significant differences in efficacy between once daily and conventional dosing for maintenance of remission. Dignass 2009 found that $2 \mathrm{~g}$ of Pentasa dosed once daily was superior to $1 \mathrm{~g}$ Pentasa ${ }^{\circledR}$ dosed twice daily for maintenance of remission at 12 months. The other Pentasa ${ }^{\circledR}$ study found no difference between once daily and conventional dosing for maintenance of remission. A plausible biological explanation for the Dignass 2009 finding is not readily apparent to us.

We believe that the methodological basis for these conclusions is relatively sound. The quality of the trials comparing once daily with conventional dosing was assessed using the Cochrane risk of bias tool and the possibility of bias was judged to be low for most items assessed. However, a concern exists regarding blinding. One open-label study (Kamm 2008) and five studies (Kane 2003a; Kane 2008a; Dignass 2009; Sandborn 2010; Hawthorne 2012) that were single-blind (investigator-blind) were rated as having a high risk of bias. However, the open-label study (Kamm 2008), and 3 of the 5 single-blind studies (Kane 2008a; Dignass 2009; Hawthorne 2012), included endoscopy as an endpoint which may provide some protection against performance and detection bias. The overall quality of the evidence using the GRADE approach was rated as moderate for the selected primary and secondary outcomes of interest due to sparse data or high risk of bias (due to blinding) in the pooled analyses.

The results of this meta-analysis suggest that there is no difference in safety between once daily and conventionally dosed mesalamine. No differences between once daily and conventionally dosed mesalamine were observed for safety outcomes including the overall incidence of adverse events or withdrawal from treatment due to an adverse event. In keeping with the wellestablished safety profile of mesalamine, most of the adverse events reported in the studies assessing once daily dosing were mild to moderate in intensity. Common adverse events included gastrointestinal symptoms (e.g. flatulence, abdominal pain, nausea, and diarrhea), headache and worsening ulcerative colitis.

Important patient preference and adherence differences may exist between dosing regimens. In the study that measured patient preference the majority of patients preferred once daily dosing to conventional dosing (Sandborn 2010). Although it is generally believed that administration of fewer tablets and less frequent dosing improves both efficacy and adherence, we could not demonstrate the superiority of once daily dosing for either of these outcomes. This result suggests that patient adherence does not appear to be enhanced by once daily dosing in the clinical trial setting. Several possible explanations exist for these observations, however the most plausible one concerns the unique aspects of 
the clinical trial environment. It is noteworthy that adherence with medication was remarkably high in the studies that measured this outcome (Kamm 2008; Dignass 2009; Prantera 2009; Hawthorne 2012; Kruis 2011). The pooled adherence rate for the maintenance of remission studies was $86 \%$ for the once daily dosing group compared to $89 \%$ for the conventional dosing group. These rates likely reflect the highly supervised environment in which the studies were conducted. Adherence with medication in clinical trials is generally greater than in clinical practice since participants are highly selected volunteers who are more likely, in general, to be adherent with drug regimens (Andrade 1995; Kane 2001; Kane 2006; Kane 2008b). In addition, adherence is continuously reinforced during the clinical trial process. Thus, it may be difficult to detect differences in adherence between once daily and multiple dose regimens in this setting.

Accordingly, a need exists to compare dosing regimens in large scale community-based studies. In this regard reported adherence rates in community based studies range from 40 to $60 \%$ and are especially poor among patients in remission (Levy 1999; Kane 2001; Kane 2003b; Shale 2003). However, whether once daily dosing regimens improve adherence in the community remains unknown. Although Kane 2003a demonstrated significantly higher adherence among patients receiving once daily dosing compared to conventional dosing at 3 months, no significant differences were found at 6 months. This time-dependent effect has recently been observed in a larger study (Sandborn 2010). Sandborn 2010 found significantly higher adherence among patients using once daily dosing compared to conventional dosing at 3 months. However no statistically significant difference in adherence was found at 6 and 12 months (Sandborn 2010).

Experience from other indications suggest that factors other than the dosing regimen are important for long-term compliance (Brixner 2007; Kane 2008b). Long-term observations in ulcerative colitis patients as well as in other indications indicate that

patients and physicians behaviors play a dominant role in adherence (Magowan 2006; Beaulieu 2009). The patient-physician relationship should reinforce adherence through education, open communication and mutual agreement regarding the value of treatment (Kane 2008b). To ensure continued adherence in a community based setting, Sandborn 2010 have emphasized the importance of health care-providers evaluating and reinforcing compliance with patients after three months of maintenance therapy.

There does not appear to be any difference in efficacy between the various formulations of oral 5-ASA. The overall pooled risk ratio (6 studies, $n=707$ ) showed no statistically significant difference in relapse between various formulations of 5-ASA (including Balsalazide, Pentasa and Olsalazine) and comparator formulations of 5-ASA (including Asacol and Salofalk). However, a GRADE analysis indicated that the overall quality of the evidence for the primary outcome (failure to maintain clinical or endoscopic remission at 12 months) was low due to a high risk of bias (single blind and openlabel) in three studies in the pooled analysis and sparse data (See Summary of findings 4). However, the open-label study (Mahmud 2002) and one of the single-blind studies (Courtney 1992), included endoscopy as an endpoint which may provide some protection against performance and detection bias.

Pharmacokinetic studies suggest that systemic exposure to 5ASA is similar for all oral 5-ASA formulations and 5-ASA prodrugs
(Sandborn 2002a; Sandborn 2002b; Sandborn 2002c; Sandborn 2003). The excretory function of the kidneys (as measured by the glomerular filtration rate) does not change during maintenance therapy with oral 5-ASA or olsalazine, and nephrotoxicity is rare for Pentasa or Asacol, suggesting that the systemic exposure to 5-ASA that occurs for doses used in clinical practice is safe for all drugs in this class (Sandborn 2002a). With the exception of olsalazinerelated diarrhea, there does not appear to be any difference in safety between the various formulations of oral 5-ASA. The overall pooled risk ratios showed no statistically significant differences in the incidence of adverse events, withdrawal due to adverse events or exclusions or withdrawals after entry. Thus, all of the 5-ASA formulations can be considered safe and effective for the treatment of active ulcerative colitis, and from a practical standpoint, they can be considered therapeutically equivalent at equimolar doses (Sandborn 2002a). Treatment with sulfasalazine and olsalazine may not be preferable due to the high frequency of adverse events. When deciding which 5-ASA formulations to use physicians and patients should consider dose-response data, adherence issues related to dose forms (size of dose form and total number of tablets or capsules per day), and price (Sandborn 2002a).

Few dose ranging maintenance studies were performed which limits the conclusions that can be drawn. Hanauer 1996 compared Asacol at a dosage of $1.6 \mathrm{~g} /$ day to $0.8 \mathrm{~g} /$ day and found no difference in relapse rates between the dosage groups.Deventer 2001 compared $3.2 \mathrm{~g} /$ day to $2 \mathrm{~g} /$ day and found no difference in relapse rates between the dosage groups. Paoluzi 2005 compared Asacol at a dosage of $2.4 \mathrm{~g} /$ day to $1.2 \mathrm{~g} /$ day and found no difference in relapse rates between the dosage groups. However, patients in the higher dosage group remained in remission longer, compared to patients in the low dose group. Paoluzi 2005 recommended a dosage of $2.4 \mathrm{~g} /$ day due to the significantly longer time to relapse in the higher dosage group. Pica 2012 compared $4.8 \mathrm{~g}$ /day to $2.4 \mathrm{~g} /$ day and found no difference in relapse rates between the dosage groups. Further research may be needed to determine the ideal dosage of Asacol for maintenance therapy.

Three studies compared the efficacy of high dose Balsalazide (4.0 to $6.0 \mathrm{~g} /$ day) to low dose (2.0 to $3.0 \mathrm{~g} /$ day). Giaffer 1992a found a dose of $4.0 \mathrm{~g} /$ day to be significantly superior to $2.0 \mathrm{~g} /$ day for preventing relapses over a 12 months period. No differences in safety between the dose groups were noted. A pooled analysis of two studies comparing Balsalazide $6.0 \mathrm{~g} /$ day to $3.0 \mathrm{~g} /$ day found no significant difference in relapse rates. However, these results should be interpreted with caution due to a high degree of heterogeneity and sparse data. The high degree of heterogeneity is due to the fact that the two studies had conflicting results. Green 1992 found no differences in relapse rates between the $6.0 \mathrm{~g} /$ day and $3.0 \mathrm{~g} /$ day groups at either 6 or 12 months. Green 1992 noted no differences in safety. Kruis 2001 found $6.0 \mathrm{~g}$ /day to be superior to $3 \mathrm{~g}$ /day for preventing relapse over a 26 week period with no differences in safety. Differences in patient populations may explain these findings. The Green 1992 study included patients with a very distal extent of ulcerative colitis and a large proportion of patients had long term remission (e.g. >1 year) at entry. Kruis 2001 suggested that patients with more extensive ulcerative colitis or with frequent relapses may benefit from a higher dose of maintenance therapy.

Kruis 2011 investigated different doses of once daily Salofalk (3 g or $1.5 \mathrm{~g}$ ) and found that significantly fewer patients relapsed at 12 months in the group receiving $3 \mathrm{~g}$ once daily (25\%) compared to 
patients in the $1.5 \mathrm{~g}$ group (39\%; $\mathrm{P}=0.002)$. This analysis involved 439 patients and provides moderate evidence (based on GRADE analysis) that $3 \mathrm{~g}$ Salofalk once daily is superior to $1.5 \mathrm{~g}$ Salofalk once daily for maintenance treatment of ulcerative colitis. No differences in safety were observed among the dose groups. In a post hoc analysis, Kruis 2011 observed that patients with active inflammation at baseline in the $3 \mathrm{~g}$ group continued to maintain a higher rate of remission than patients receiving lower doses (i.e. 1.5 $\mathrm{g}$ once daily or $0.5 \mathrm{~g}$ three times daily). Kruis 2011 concluded that 3 g once daily is an appropriate dose for maintenance of remission, and may be beneficial for patients with signs of inflammation or in whom endoscopic data are not available. No other maintenance studies looked at dose-ranging for once daily treatment using other 5-ASA formulations.

Travis 1994 compared the efficacy of Olsalazine $2.0 \mathrm{~g}$ /day to 1.0 $\mathrm{g} /$ day and $0.5 \mathrm{~g} /$ day. No significant differences in relapse at 12 months were found between the $2.0 \mathrm{~g}$ and $1.0 \mathrm{~g}$ /day groups. A dosage of $2.0 \mathrm{~g} /$ day was significantly superior to $0.5 \mathrm{~g} /$ day for preventing relapse. No differences in safety were noted. Subgroup analysis showed that patients with proctitis and recent relapse may benefit from a dosage of $2.0 \mathrm{~g} /$ day (Travis 1994). Fockens 1995 compared the efficacy of Pentasa $3.0 \mathrm{~g} /$ day to $1.5 \mathrm{~g} /$ day. Although there was a trend favouring the higher dose there was no statistically significant difference in prevention of relapse over a one year period. The higher dosage was not associated with a higher incidence of adverse events (Fockens 1995).

\section{AUTHORS' CONCLUSIONS}

\section{Implications for practice}

It is clear that oral 5-ASA preparations have yet to be proven to be more clinically beneficial than SASP. Male infertility is associated with SASP and not with 5-ASA (Riley 1987; Kjaergaard 1989), so 5-ASA may be preferred for patients concerned about fertility. 5-ASA therapy is more expensive than SASP, so SASP may be the preferred option where cost is an important factor. 5-ASA could also be offered to patients who are intolerant to SASP. Oral 5-ASA administered once daily is as effective and safe as conventional dosing (twice or three times daily) for maintenance of remission in quiescent ulcerative colitis. Once daily dosing does not appear to enhance adherence in the clinical trial setting. There does not appear to be any difference in efficacy or safety between the various formulations of 5-ASA. Patients with extensive ulcerative colitis or with frequent relapses may benefit from a higher dose of maintenance therapy. High dose therapy appears to be as safe as low dose and is not associated with a higher incidence of adverse events. When selecting among the various 5ASA formulations, physicians and patients should consider doseresponse data, adherence issues and price (Sandborn 2002a).

\section{Implications for research}

In this time of scarce research dollars, careful thought should be given prior to commissioning new trials of 5-ASA preparations for the treatment of quiescent ulcerative colitis. Future trials comparing 5-ASA with placebo or SASP may not be justified. There does not appear to be any difference in efficacy or safety between the various formulations of 5-ASA. However the overall quality of the evidence from the studies examining differences in efficacy between various 5-ASA formulations is low due to sparse data and risk of bias. Future trials should look at enhancing patient adherence with medication. Adherence to therapy is important for treatment success and may be an important predictor of relapse. Future trials could assess whether once daily dosing regimens improve adherence in the community.

\section{ACKNOWLEDGEMENTS}

Funding for the IBD/FBD Review Group (September 1, 2010 - August $31,2015)$ has been provided by the Canadian Institutes of Health Research (CIHR) Knowledge Translation Branch (CON - 105529) and the CIHR Institutes of Nutrition, Metabolism and Diabetes (INMD); and Infection and Immunity (III) and the Ontario Ministry of Health and Long Term Care (HLTC3968FL-2010-2235).

Miss Ila Stewart has provided support for the IBD/FBD Review Group through the Olive Stewart Fund. 


\section{R E F E R E N C E S}

\section{References to studies included in this review}

\section{Andreoli 1987 \{published data only\}}

Andreoli A, Cosintino R, Trotti R, Berri F, Prantera C. 5aminosalicylic acid (5-ASA) versus salazopirin (SASP) in the oral treatment of active ulcerative colitis (UC) and in remission [abstract]. Clinical Controversies in Inflammatory Bowel Disease 1987:170.

\section{Ardizzone 1995 \{published data only\}}

* Ardizzone S, Petrillo M, Molteni P, Desideri S, Bianchi Porro G. Coated oral 50 aminosalicylic acid (Claversal) is equivalent to sulfasalazine for remission maintenance in ulcerative colitis. Journal of Clinical Gastroenterology 1995;21:287-9.

Bianchi Porro GB, Ardizzone S, Fasoli R, Petrillo M, Desideri S. Comparison of mesalazine with sulphasalazine in prophylactic treatment of ulcerative collitis [abstract]. Gut 1989;30:A1467.

Ardizzone 1999 \{published data only\}

Ardizzone S, Petrillo M, Imbesi V, Cerutti R, Bollani S, Bianchi Porro $G$. Is maintenance therapy always necessary for patients with ulcerative colitis?. Alimentary Pharmacology and Therapeutics 1999;13:373-9.

\section{Courtney 1992 \{published data only\}}

Courtney MG, Nunes DP, Bergin CF. Prospective randomized trial of mesalazine versus olsalazine in ulcerative colitis. Gastroenterology 1990;98(5 Part 2):A165.

* Courtney MG, Nunes DP, Bergin CF, O'Driscoll M, Trimble V, Keeling PWN, et al. Randomised comparison of olsalazine and mesalazine in prevention of relapses in ulcerative colitis. Lancet 1992;339:1279-81.

\section{D'Haens 2012 \{published data only\}}

D'Haens G, Sandborn WJ, Barrett K, Hodgson I, Streck P. Once-daily $\mathrm{MMX}^{\circledR}$ mesalamine for endoscopic maintenance of remission of ulcerative colitis. American Journal of Gastroenterology 2012;107(7):1064-77.

\section{Deventer 2001 \{published data only\}}

Deventer SJH, Hommes DW, Roskam-Mul MDM, Dekker W, Gasthuis K, Wetzels A, et al. Prospective randomized open label blinded endpoint (PROBE) trial of high versus low dose mesalazine for prevention of relapse in patients with UC in remission. Gastroenterology 2001;120(5 Suppl 1):A454.

\section{Dew 1983a $\{$ published data only\}}

* Dew MJ, Harries AD, Evans N, Evans BK, Rhodes J. Maintenance of remission in ulcerative colitis with 5aminosalicylic acid in high doses by mouth. British Medical Journal 1983;287:23-4.

Dew MJ, Harries AD, Evans N, Evans BK, Rhodes J. Maintenance of remission in ulcerative colitis with an oral preparation of 5aminosalicylic acid in high doses. Gut 1983;24(Suppl 10):A983.
Dignass 2009 \{published data only\}

Bokemeyer B, Hommes D, Gill I, Broberg P, Dignass A. Mesalazine in left-sided ulcerative colitis: efficacy analyses from the PODIUM trial on maintenance of remission and mucosal healing. Journal of Crohn's and Colitis 2012;6(4):476-82.

Dignass A, Bokemeyer B, Mross M, Oudkerk Pool M. Symptom resolution and clinical remission in patients with mild-tomoderate ulcerative colitis: analysis of the PODIUM trial. Journal of Crohn's and Colitis 2013;7:S153-4.

Dignass A, Bokemeyer B, Stijnen T, Klugmann T, Oudkerk M, Veerman $\mathrm{H}$. Impact of once-daily versus twice-daily mesalazine (Pentasa) on relief of rectal bleeding and stool frequency: results from a multinational randomised controlled trial. Canadian Journal of Gastroenterology 2009;23.

Dignass A, Bokemeyer B, Stijnen T, Tan T, Borner N, Oudkerk Pool M, et al. Safety of once-daily vs twice-daily mesalazine (Pentasa) dosing. Results from a 12-month randomised controlled trial in maintenance of remission of ulcerative colitis. Canadian Journal of Gastroenterology 2009;23.

Dignass A, Stijnen T, Mross MR, Vermeire S, Veerman $\mathrm{H}$, Bhatt A. Pentasa (mesalazine) once or twice daily for the management of maintenance of remission of ulcerative colitis: demographic and baseline data of a 12 month single blind randomised controlled trial. Gastroenterology 2007;132(4 Suppl 1):A502-3.

Dignass A, Vermeire S, Adamek H, Befrits R, Bokemeyer B, Börner $\mathrm{N}$, et al. Improved remission rates from once- versus twice-daily mesalazine (Pentasa) granules for the maintenance of remission in ulcerative colitis: results from a multinational randomised controlled trial. UEGW - Abstract Database 2007.

* Dignass AU, Bokemeyer B, Adamek H, Mross M, VinterJensen L, Börner N, et al. Mesalamine once daily is more effective than twice daily in patients with quiescent ulcerative colitis. Clinical Gastroenterology and Hepatology 2009;7(7):762-9.

Dignass AU, Bokemeyer B, Adamek HE, Mross MR, VinterJensen L, Boerner N, et al. Maintenance therapy with oncedaily $2 \mathrm{~g}$ mesalazine (Pentasa) treatment improves remission rates in subjects with ulcerative colitis compared to twice daily $1 \mathrm{~g}$ mesalazine: data from a randomised controlled trial. Gastroenterology 2008;134(4 Suppl 1):A494.

Dignass AU, Bokemeyer B, Adamek HE, Mross MR, VinterJensen L, Boerner N, et al. Treatment acceptability in a randomised controlled trial of once-daily or twice-daily mesalazine (Pentasa) for the maintenance of remission in ulcerative colitis. Gastroenterology 2008;134(4 Suppl 1):A495-6.

Dignass AU, Bokemeyer B, Stijnen T, Veerman H. Impact of once - daily versus twice-daily mesalazine (Pentasa) on relief of rectal bleeding and stool frequency: results from a multinational randomised controlled trial. Gastroenterology 2009;136(5 Suppl 1):A685. 
Dignass AU, Muls V, Silvennoinen J, Pool MO, Befrits R, Broberg $\mathrm{P}$, et al. The PODIUM trial of once-daily versus twicedaily mesalazine dosing in ulcerative colitis: maintenance of mucosal healing. Gastroenterology 2010;1:S520.

Vermeire S, Befrits R, Bokemeyer B, Gill I, Hommes DW, Broberg P, et al. Efficacy of once-daily versus twice-daily mesalazine (Pentasa): Sub-analysis of the left-sided colitis population in the randomised PODIUM trial. Gastroenterology 2010;1:S522.

\section{Fockens 1995 \{published data only\}}

* Fockens P, Mulder CJ, Tytgat GN, Blok P, Ferwerda J, Meuwissen SG, et al. Comparison of the efficacy and safety of 1.5 compared with $3.0 \mathrm{~g}$ oral slow-release mesalazine (Pentasa) in the maintenance treatment of ulcerative colitis. Dutch Pentasa Study Group. European Journal of Gastroenterology and Hepatology 1995;7(11):1025-30.

Fockens P, Mulder CJJ, Ferwada J, Tytgat GNJ, and the Dutch Pentasa Study Group. Relapse prevention of ulcerative colitis: double-blind comparison of 1.5 gram versus 3 gram oral mesalazine (Pentasa) [abstract]. Gastroenterology 1993;104:A701.

\section{Giaffer 1992a \{published data only\}}

Giaffer MH, Holdsworth CD, Lennard-Jones JE, Rodrigues CA, McIntyre PB, Manjunatha S, et al. Improved maintenance of remission in ulcerative colitis by balsalazide $4 \mathrm{~g}$ /day compared with $2 \mathrm{~g} /$ day. Alimentary Pharmacology and Therapeutics 1992;6:479-85.

\section{Green 1992 \{published data only\}}

* Green JRB, Swan CHJ, Rowlinson A, Gibson JA, Brown P, Kerr GD, et al. Short report: comparison of two doses of balsalazide in maintaining ulcerative colitis in remission over 12 months. Alimentary Pharmacology and Therapeutics 1992;6:647-52.

Green JRB, Swan CHJ, Rowlinson AE, Gibson JA, Brown P, Kerr GD, et al. A three-year prospective study of the maintenance of remission of ulcerative colitis by a new 5-ASA releasing agent, balsalazide. Gastroenterology 1992;102(4 Part 2):A631.

\section{Green 1998 \{published data only\}}

Green JR, Gibson JA, Kerr GD, Swarbrick ET, Lobo AJ, Holdsworth CD, et al. Maintenance of remission of ulcerative colitis: a comparison between balsalzide $3 \mathrm{~g}$ daily and mesalazine $1.2 \mathrm{~g}$ daily over 12 months. Alimentary Pharmacology and Therapeutics 1998;12:1207-16.

\section{Hanauer 1996 \{published data only\}}

Hanauer S, Powers B, Robinson M, Mayle J, Elson C. Maintenance of remission of ulcerative colitis by mesalamine (Asacol) versus placebo [abstract]. Gastroenterology 1994;106:A696.

* Hanauer SB, Sninsky CA, Robinson M, Powers BJ, McHattie JD, Mayle JE, et al. An oral preparation of mesalamine as long-term maintenance therapy for ulcerative colitis. A randomized, placebo-controlled trial. Annals of Internal Medicine 1996;124:204-11.

Hawkey 1997 \{published data only\}

Hawkey CJ, Dube LM, Rountree LV, Linnen PJ, Lancaster JF, and the European Zileuton Study Group for Ulcerative Colitis. A trial of zileuton versus mesalazine or placebo in the maintenance of remission of ulcerative colitis. Gastroenterology 1997;112:718-24

\section{Hawthorne 2012 \{published data only\}}

Hawthorne AB, Stenson R, Gillespie D, Swarbrick ET, Dhar A, Kapur KC, et al. Once daily asacol in maintenance therapy for ulcerative colitis: a one-year singe-blind randomised trial. Gut 2011;60:A37-8.

Hawthorne AB, Stenson R, Gillespie D, Swarbrick ET, Dhar A, Kapur KC, et al. Once daily mesalazine as maintenance therapy for ulcerative colitis (UC): A one-year single-blind randomised trial. Gastroenterology 2011;140(5 Suppl 1):S65.

* Hawthorne AB, Stenson R, Gillespie D, Swarbrick ET, Dhar A, Kapur KC, et al. One-year investigator-blind randomized multicenter trial comparing Asacol $2.4 \mathrm{~g}$ once daily with 800 $\mathrm{mg}$ three times daily for maintenance of remission in ulcerative colitis. Inflammatory Bowel Disease 2012;18(10):1885-93.

\section{Ireland 1988 \{published data only\}}

Ireland A, Jewell DP. Comparative trial of olsalazine and sulfasalazine for the maintenance treatment of ulcerative colitis (UC) [abstract]. Gastroenterology 1987;92:A1447.

* Ireland A, Mason CH, Jewell DP. Controlled trial comparing olsalazine and sulphasalazine for the maintenance treatment of ulcerative colitis. Gut 1988;29:835-7.

Jewell DP, Ireland A. Controlled trial comparing olsalazine and sulfasalazine for maintenance treatment of ulcerative colitis. Scandinavian Journal of Gastroenterology. Supplement 1988;148:45-7.

\section{Ito 2010 \{published data only\}}

Ito $\mathrm{H}$, lida M, Matsumoto T, Suzuki Y, Aida Y, Yoshida T, et al. Direct comparison of two different mesalamine formulations for the maintenance of remission in patients with ulcerative colitis: a double-blind, randomized study. Inflammatory Bowel Diseases 2010;16(9):1575-82.

\section{Kamm 2008 \{published data only\}}

Kamm MA, Colombel J, Kornbluth A, Diebold R, Barrett K, Karlstadt RG, et al. A randomized comparison of once- versus twice-Daily $M M X^{\oplus}$ mesalamine for the maintenance of remission in mild-to-moderate ulcerative colitis. Gastroenterology 2007;132(4 Suppl 1):A510.

* Kamm MA, Lichtenstein GR, Sandborn WJ, Schreiber S, Lees K, Barrett K, et al. Randomised trial of once- or twice-daily MMX mesalazine for maintenance of remission in ulcerative colitis. Gut 2008;57(7):893-902.

Kamm MA, Schreiber S, Butler T, Barrett K, Stephenson D, Joseph RE. Safety analysis of MMX mesalazine for the maintenance of remission of mild-to-moderate ulcerative 
colitis: results of 4-month interim data analysis. UEGW Abstract Database 2006.

Rubin D, Dubinsky M, Panaccione R, Siegel C, Binion D, Kane S, et al. Ulcerative colitis: patients' perceptions compared with other chronic diseases. Inflammatory Bowel Diseases 2008;14(S1):S22.

Sandborn W, Kamm M, Lichtenstein G, Barrett K, Joseph R. $M M X^{\mathrm{TM}}$ mesalamine for the maintenance of remission in mildto-moderate ulcerative colitis. Inflammatory Bowel DIseases 2008;14(S1):S24.

\section{Kane 2003a \{published data only\}}

Kane S, Huo D, Magnanti K. A pilot feasibility study of once daily versus conventional dosing mesalamine for maintenance of ulcerative colitis. Clinical Gastroenterology and Hepatology 2003;1(3):170-3.

\section{Kane 2008a \{published data only\}}

Kane S, Holderman W, Jacques P, Miodek T. Once daily versus conventional dosing of $\mathrm{pH}$-dependent mesalamine long-term to maintain quiescent ulcerative colitis: Preliminary results from a randomized trial. Patient Preference and Adherence 2008;2(2):253-8.

\section{Kiilerich 1992 \{published data only\}}

Kiilerich S, Ladefoged K, Rannem T, Ranlov P. Prophylactic effects of olsalazine (OLZ) versus sulfasalazine (SASP) in 12 months' maintenance treatment of ulcerative colitis. Gastroenterology 1991;100(5 Part 2):A220.

* Kiilerich S, Ladefoged K, Rannem T, Ranlov PJ. Prophylactic effects of olsalazine versus sulphasalazine during 12 months maintenance treatment of ulcerative colitis. Danish Olsalazine Study Group. Gut 1992;33:252-5.

\section{Kruis 1995 \{published data only\}}

* Kruis W, Judmaier G, Kayasseh L, Stole M, Theuer D, Scheurlen C, et al. Double-blind dose-finding study of olsalazine versus sulphasalazine as maintenance therapy for ulcerative colitis. European Journal of Gastroenterology and Hepatology 1995;7:391-6.

Kruis W, Judmaier G, Kayasseh L, Stolte M, Scheurlen C, Hentschel E, et al. Double-blind dose-finding study of olsalazine vs. sulfasalazine for maintenance therapy of ulcerative colitis [abstract]. Gastroenterology 1992;102:A649.

Kruis W, Stolte M. A double-blind dose finding study of olsalazine for the maintenance treatment of quiescent ulcerative colitis. Gastroenterology 1991;100(5 Part 2):A222.

\section{Kruis 2001 \{published data only\}}

Kruis W, Schreiber S, Theuer D, Brandes JW, Schutz E, Howaldt S, et al. Low dose balsalazide ( $1.5 \mathrm{~g}$ twice daily) and mesalazine ( $0.5 \mathrm{~g}$ three times daily) maintained remission of ulcerative colitis but high dose balsalazide ( $3.0 \mathrm{~g}$ twice daily) was superior in preventing relapses. Gut 2001;49(6):783-9.

\section{Kruis 2011 \{published data only\}}

Kruis W, Greinwald R, Mueller R. Optimal dosing of mesalamine for maintenance of clinical remission in patients with distal ulcerative colitis and residual endoscopic activity: a subgroup analysis of a double-blind, double-dummy, randomized, controlled, dose-ranging study. Gastroenterology 2013;144(5 Suppl 1):S768.

Kruis W, Jonaitis L, Pokrotnieks J, Acute G, Mikhailova TL, Horynski M, et al. Once Daily $3 \mathrm{~g}$ mesalamine is the optimal dose for maintaining clinical remission in ulcerative colitis: a doubleblind, double-dummy, randomized, controlled, dose-ranging study. Gastroenterology 2008;134(4 Suppl 1):A489.

* Kruis W, Jonaitis L, Pokrotnieks J, Mikhailova TL, Horynski M, Bátovský M, et al. Randomised clinical trial: a comparative dose-finding study of three arms of dual release mesalazine for maintaining remission in ulcerative colitis. Alimentary Pharmacology and Therapeutics 2011;33(3):313-22.

\section{Lichtenstein 2010 \{published data only\}}

Lichtenstein GR, Gordon GL, Zakko S, Murthy U, Sedghi S, Pruitt R, et al. Clinical trial: once-daily mesalamine granules for maintenance of remission of ulcerative colitis - a 6-month placebo-controlled trial. Alimentary Pharmacology and Therapeutics 2010;32(8):990-9.

\section{Mahmud 2002 \{published data only\}}

Mahmud N, O'Toole D, O'Hare N, Freyne PJ, Weir DG, Kelleher D. Evaluation of renal function following treatment with 5aminosalicylic acid derivatives in patients with ulcerative colitis. Alimentary Pharmacology and Therapeutics 2002;16(2):207-15.

\section{McIntyre 1988 \{published data only\}}

McIntyre PB, Rodrigues CA, Lennard-Jones JE, Barrison IG, Walker JG, Baron JH. Double blind controlled comparison of balsalazide and sulphasalazine in maintenance therapy of patients with ulcerative colitis [abstract]. Gut 1986;27:A1271.

* McIntyre PB, Rodrigues CA, Lennard-Jones JE, Barrison IG, Walker JG, Baton JH, et al. Balsalazine in the maintenance treatment of patients with ulcerative colitis, a double-blind comparison with sulphasalazine. Alimentary Pharmacology and Therapeutics 1988;2:237-43.

\section{Miner 1995 \{published data only\}}

* Miner P, Hanauer S, Robinson M, Schwartz J, Arora S, and Pentasa UC Maintenance Study Group. Safety and efficacy of controlled-release mesalamine for maintenance of remission in ulcerative colitis. Digestive Diseases and Sciences 1995;40:296-304.

Miner P, Schwartz J, Aora S, Robinson M, Hanauer S, and the Pentasa Study Group. Maintenance of remission in ulcerative colitis (UC) patients with controlled-release mesalamine capsules (Pentasa) [abstract]. Gastroenterology 1992;102:A666.

\section{Mulder 1988 \{published data only\}}

* Mulder CJ, Tytgat GN, Weterman IT, Dekker W, Blok P, Schrijver M, et al. Double-blind comparison of slow-release 5aminosalicylate and sulfasalazine in remission maintenance in ulcerative colitis. Gastroenterology 1988;95:1449-53. 
Mulder CJJ, Tytgat GNJ, Weterman IT. Double blind evaluation of slow-release 5-aminosalicylic acid (Pentasa) and salazopyridin (Salazopyrin) in the maintenance therapy of ulcerative colitis. Gastroenterology 1988;94(5 Part 2):A313.

\section{Nilsson 1995 \{published data only\}}

Nilsson A, Danielsson A, Lofberg R, Benno P, Bergman L, Fausa $\mathrm{O}$, et al. Olsalazine versus sulphasalazine for relapse prevention in ulcerative colitis: a multicenter study. American Journal of Gastroenterology 1995;90:381-7.

Paoluzi 2005 \{published data only\}

* Paoluzi OA, lacopini F, Pica R, Crispino P, Marcheggiano A, Consolazio A, et al. Comparison of two different daily dosages (2.4 vs. $1.2 \mathrm{~g}$ ) of oral mesalazine in maintenance of remission in ulcerative colitis patients: 1 -year follow-up study. Alimentary Pharmacology and Therapeutics 2005;21(9):1111-9.

Paoluzi OA, Pica R, Crispino P, lacopini F, Consolazio A, Rivera M, et al. Doubling daily dosage of oral mesalazine ( $2.4 \mathrm{vs} .1 .2 \mathrm{~g}$ ) in the maintenance therapy of pts with ulcerative colitis delays but does not reduce incidence of relapses: a 1-year follow-up study. Gastroenterology 2005;128(4 Suppl 2):A585.

\section{Pica 2012 \{published data only\}}

Pica R, Cassieri C, Cocco A, Marcheggiano A, Occhigrossi G, Zippi M, et al. Randomised open label trial comparing two different dosages of oral mesalazine in the maintainence treatment of ulcerative colitis. Italian Journal of Medicine 2012;1:108.

\section{Prantera 2009 \{published data only\}}

Kohn A, Prantera C, Caprilli R, Campieri M, Cottone M, Pallone F, et al. Maintenance treatment of ulcerative colitis with 5aminosalicylic acid (5-ASA): results from the Italian population of a one year, randomized, multinational study comparing MMx ${ }^{\circledR}$ with Asacol ${ }^{\circledR}$. Gastroenterology 2009;136(5 Suppl 1):390.

* Prantera C, Kohn A, Campieri M, Caprilli R, Cottone M, Pallone $\mathrm{F}$, et al. Clinical trial: ulcerative colitis maintenance treatment with 5-ASA: a 1-year, randomized multicentre study comparing MMX with Asacol. Alimentary Pharmacology and Therapeutics 2009;30(9):908-18.

Rijk 1992 \{published data only\}

* Rijk MCM, Lier HJJ, Tongerson JHM. Relapse-preventing effect and safety of sulfasalazine and olsalazine in patients with ulcerative colitis in remission: prospective, doubleblind, randomized multicenter study. American Journal of Gastroenterology 1992;87:438-42.

Rijk MCM, van Tongersen JHM. The relapse preventing effect and safety of sulphasalazine and olsalazine in patients with ulcerative colitis in remission. Gastroenterology 1991;100(5 Part 2):A243.

\section{Riley 1988 \{published data only\}}

* Riley SA, Mani V, Goodman MJ, Herd ME, Dutt S, Turnberg LA. Comparison of delayed-release 5-aminosalicylic acid (mesalazine) and sulfasalazine as maintenance treatment for patients with ulcerative colitis. Gastroenterology 1988;94:1383-9.
Riley SA, Mani V, Goodman MJ, Turnberg LA. A comparison of delayed-release 5-ASA and sulfasalazine as maintenance treatment in ulcerative colitis [abstract]. Gastroenterology 1987;92:A1596.

Riley SA, Mani V, Goodman MJ, Turnberg LA. A comparison of delayed-release 5-aminosalicylic acid (5-ASA) and sulfasalazine (SSZ) as maintenance treatment of ulcerative colitis (UC) [abstract]. Gut 1987;28:1390.

\section{Rutgeerts 1989 \{published data only\}}

Rutgeerts P. Comparative efficacy of coated, oral 5aminosalicylic acid (Claversal) and sulphasalazine for maintaining remission of ulcerative colitis. Alimentary Pharmacology and Therapeutics 1989;3:183-91.

\section{Sandberg-Gertzen 1986 \{published data only\}}

Jarnerot G, Sandberg-Gertzen H. Azodisal sodium, (ADS), Dipentum, as relapse prevention in ulcerative colitis (UC). a double-blind placebo controlled study. Gastroenterology 1985;88(5 Part 2):A1432.

* Sandberg-Gertzen H, Jarnerot G, Kraaz W. Azodisal sodium in the treatment of ulcerative colitis: a study of tolerance and relapse prevention properties. Gastroenterology 1986;90:1024-30.

\section{Sandborn 2010 \{published data only\}}

Sandborn W, Kane S, Korzenik J, Lashner B, Leighton J, Mahadevan U, et al. Once daily dosing of delayed-release oral mesalamine for maintenance of remission of ulcerative colitis (the QDIEM trial): 6 and 12 month results. Inflammatory Bowel Diseases 2009;15:S15.

* Sandborn WJ, Korzenik J, Lashner B, Leighton JA, Mahadevan U, Marion JF, et al. Once-daily dosing of delayedrelease oral mesalamine (400-mg tablet) is as effective as twicedaily dosing for maintenance of remission of ulcerative colitis. Gastroenterology 2010;138(4):1286-96.

Travis 1994 \{published data only\}

Travis SPL, Tysk C, de Silva HJ, Sandberg-Gertzen H, Jewell DP, Jarnerot G. Optimum dose of olsalazine for maintaining remission in ulcerative colitis. Gut 1994;35:1282-6.

\section{Watanabe 2013 \{published data only\}}

Watanabe M, Hanai H, Nishino H, Yokoyama T, Terada T, Suzuki Y. Comparison of QD and TID oral mesalazine for maintenance of remission in quiescent ulcerative colitis: a double-blind, double-dummy, randomized multicenter study. Inflammatory Bowel Diseases 2013;19(8):1681-90.

\section{Wright 1993 \{published data only\}}

* Wright JP, O'Keefe EA, Cuming L, Jaskiewicz K. Olsalazine in maintenance of clinical remission in patients with ulcerative colitis. Digestive Diseases and Sciences 1993;38:1837-42.

Wright JP, O'Keefe EA, Cuming L, Jaskiewicz K. Olsalazine in the maintenance of remission in patients with ulcerative colitis [abstract]. Gastroenterology 1992;102:A714. 


\section{References to studies excluded from this review}

\section{Bardazzi 1994 \{published data only\}}

Bardazzi G, d'Albasio G, Bonanomi AG, Trallori G, Messori A, Amorosi A, et al. Intermittent versus continuous 5aminosalicylic acid treatment for maintaining remission in ulcerative colitis. Italian Journal of Gastroenterology 1994;26(7):334-7.

\section{d'Albasio 1997 \{published data only\}}

d'Albasio G, Pacini F, Camarri E, Messori A, Trallori G, Bonanomi AG, et al. Combined therapy with 5-aminosalicylic acid tablets and enemas for maintaining remission in ulcerative colitis: a randomized double-blind study. American Journal of Gastroenterology 1997;92(7):1143-7.

Dew 1982b \{published data only\}

Dew MJ, Hughes P, Harries AD, Williams G, Evans BK, Rhodes J. Maintenance of remissions in ulcerative colitis with oral preparation of 5-aminosalicylic acid. British Medical Journal 1982;285:1012.

\section{Eliakim 1990 \{published data only\}}

Eliakim R, Wengrower D, Ligumsky M, Rachmilewitz D. Comparable efficacy of oral 5-ASA (Mesasal) and sulfasalazine in maintaining ulcerative colitis in remission. Israel Journal of Medical Sciences 1990;26(1):47-9.

\section{Ewe 1996 \{published data only\}}

Ewe K, Becker K, Ueberschaer B. Systemic uptake of 5aminosalicylic acid from olsalazine and eudragit $L$ coated mesalazine in patients with ulcerative colitis in remission. Zeitschrift fur Gastroenterologie 1996;34(4):225-9.

\section{Fernández-Bañares 1999 \{published data only\}}

Fernández-Bañares F, Hinojosa J, Sánchez-Lombraña JL, Navarro E, Martínez-Salmerón JF, García-Pugés A, et al. Randomized clinical trial of Plantago ovata seeds (dietary fiber) as compared with mesalamine in maintaining remission in ulcerative colitis. Spanish Group for the Study of Crohn's Disease and Ulcerative Colitis (GETECCU). American Journal of Gastroenterology 1999;94(2):427-33.

\section{Frieri 2005 \{published data only\}}

Frieri G, Pimpo M, Galletti B, Palumbo G, Corrao G, Latella G, et al. Long-term oral plus topical mesalazine in frequently relapsing ulcerative colitis. Digestive and Liver Disease 2005;37(2):92-6.

\section{Giaffer 1992b \{published data only\}}

Giaffer MH, O'Brien CJ, Holdsworth CD. Clinical tolerance to three 5 -aminosalicylic acid releasing preparations in patients with inflammatory bowel disease intolerant or allergic to sulphasalazine. Alimentary Pharmacology and Therapeutics 1992;6(1):51-9.

\section{Gionchetti 1990 \{published data only\}}

Gionchetti P, Campieri M, Belluzzi A, Brignola C, Tampieri M, lannone $P$, et al. Pentasa in maintenance treatment of ulcerative colitis [letter, comment]. Gastroenterology 1990;98:251.

\section{Gionchetti 1996 \{published data only\}}

Gionchetti P, Campieri M, Venturi A, Rizzello F, Ferretti M, Brignola C, et al. Systemic availability of 5-aminosalicylic acid: comparison of delayed release and an azo-bond preparation. Alimentary Pharmacology and Therapeutics 1996;10(4):601-5.

\section{Green 2004 \{published data only\}}

Green JR, Swan CH, Gibson JA, Kerr GD, Swarbrick ET, Thornton PC. Patient-led variable dosing with balsalazide as long-term therapy for maintenance in ulcerative colitis: a 3-year prospective observational study. Alimentary Pharmacology and Therapeutics 2004;19(4):435-42.

Hanauer 2009 \{published data only\}

Hanauer SB, Lichtenstein GR, Kamm MA, Sandborn WJ, Lees $\mathrm{KH}$, Barrett $\mathrm{K}$, et al. MMX mesalamine for induction and maintenance therapy in mild-to-moderate ulcerative colitis. Gastroenterology and Hepatology 2009;5(7):494-500.

Karamanolis 1996 \{published data only\}

Karamanolis DG, Papatheodoridis GV, Xourgias V. Systemic absorption of 5-aminosalicylic acid in patients with inactive ulcerative colitis treated with olsalazine and mesalazine. European Journal of Gastroenterology and Hepatology 1996;8(11):1083-8.

\section{Kruis 1997 \{published data only\}}

Kruis W, Schütz E, Fric P, Fixa B, Judmaier G, Stolte M. Doubleblind comparison of an oral Escherichia coli preparation and mesalazine in maintaining remission of ulcerative colitis. Alimentary Pharmacology and Therapeutics 1997;11(5):853-8.

\section{Kruis 2004 \{published data only\}}

Kruis W, Fric P, Pokrotnieks J, Lukas M, Fixa B, Kascak M, et al. Maintaining remission of ulcerative colitis with the probiotic Esherichia coli Nissle 1917 is as effective as with standard mesalazine. Gut 2004;53(11):1617-23.

\section{Mani 1994 \{published data only\}}

Mani V, Gotch P. Comparison of pharmacokinetics and colonic transit time in quiescent ulcerative colitis on mesalazine and olsalazine - A cross over study [abstract]. Gut 1994;35(Suppl 4):A124.

\section{Mantzaris 2004 \{published data only\}}

Mantzaris GJ, Sfakianakis M, Archavlis E, Petraki K, Christidou A, Karagiannidis A, et al. A prospective randomized observerblind 2-year trial of azathioprine monotherapy versus azathioprine and olsalazine for the maintenance of remission of steroid-dependent ulcerative colitis. American Journal of Gastroenterology 2004;99(6):1122-8.

Odes 1997 \{published data only\}

Odes HS. 5-Aminosalicylic acid, 1,000-mg caplets versus 500$\mathrm{mg}$ tablets, in maintenance of remission in ulcerative colitis. Journal of Clinical Gastroenterology 1997;24(4):287-8.

\section{Osterman 2014 \{published data only\}}

Osterman MT, Aberra F, Cross R, Liakos S, McCabe RP, Shafran I, et al. A randomized controlled trial of mesalamine dose 
escalation for ulcerative colitis in remission. Gastroenterology 2014;146(5 Suppl 1):S149.

\section{Paoluzi 2002 \{published data only\}}

Paoluzi P, D'Albasio G, Pera A, Bianchi Porro G, Paoluzi OA, Pica R, et al. Oral and topical 5-aminosalicylic acid (mesalazine) in inducing and maintaining remission in mild-moderate relapse of ulcerative colitis: one-year randomised multicentre trial. Digestive and Liver Disease 2002;34(11):787-93.

Papatheodoridis 1995 \{published data only\} Papatheodoridis GV, Xourgias V, Sdonas T, Triantoafyllou M, Tzouvaia M, Karamanolis DG. Systematic load of 5-ASA in patients with inactive ulcerative colitis treated with olsalazine and mesalazine [abstract]. Gut 1995;37(Suppl 2 Pt 2):A54.

Pelech 1998 \{published data only\}

Pelech T, Fric P, Fixa B, Komarkova O. Comparison of Mutaflor and mesalazine in the maintenance treatment of inactive ulcerative colitis. Prakticky Lekar 1998;78(10):556-8.

\section{Staerk Laursen 1990 \{published data only\}}

Staerk Laursen L, Stokholm M, Bukhave K, Rask-Madsen J, Lauritsen K. Disposition of 5-aminosalicylic acid by olsalazine and three mesalazine preparations in patients with ulcerative colitis: Comparison of intraluminal colonic concentrations, serum values, and urinary excretion. Gut 1990;31:1271-6.

\section{Stoa-Birketvedt 1999 \{published data only\}}

Florholmen J. The systemic load and efficient delivery of active 5-ASA in patients with ulcerative colitis on treatment with Dipentum (Olsalazine) and Mesasael (Mesalazine) [abstract]. Gut 1994;35(Suppl 4):A121.

* Stoa-Birketvedt G, Florholmen J. The systemic load and efficient delivery of active 5-aminosalicylic acid in patients with ulcerative colitis on treatment with olsalazine or mesalazine. Alimentary Pharmacology and Therapeutics 1999;13:357-61.

\section{Tragnone 1996 \{published data only\}}

Tragnone A, Elmi G, Tagliente C, Bazzocchi G, Dina R, Euseb V, et al. Oral 5-aminosalicylic acid therapy for the prevention of relapse in patients with ulcerative colitis (UC) during remission: a new therapeutical approach by using 5-ASA tablets 800 mg. A multicenter controlled randomized trial [abstract]. Gastroenterology 1996;110:A1030.

\section{Tzivras 1997 \{published data only\}}

Archimandritis A, Hatzis G, Konstandinidis A, Paraskeva K, Tjivras M, Skandalis N. Disposition of 5-ASA by olsalazine (Dipentum) and mesalazine (Asacol) in patients with ulcerative colitis in remission [abstract]. Gut 1996;39(Suppl 3):A75.

* Tzivras M, Konstandinidis A, Hatzis G, Paraskeva K, Skandalis N, Archimandritis A. Systemic absorption of 5aminosalicylic acid in patients with inactive ulcerative colitis treated with olsalazine and mesalazine. European Journal of Gastroenterology and Hepatology 1997;9(7):729-30.

\section{Yokoyama 2007 \{published data only\}}

Yokoyama H, Takagi S, Kuriyama S, Takahashi S, Takahashi H, Iwabuchi M, et al. Effect of weekend 5-aminosalicylic acid (mesalazine) enema as maintenance therapy for ulcerative colitis: results from a randomized controlled study. Inflammatory Bowel Diseases 2007;13(9):1115-20.

Zocco 2006 \{published data only\}

Zocco MA, Dal Verme LZ, Cremonini F, Piscaglia AC, Nista EC, Candelli M, et al. Efficacy of Lactobacillus GG in maintaining remission of ulcerative colitis. Alimentary Pharmacology and Therapeutics 2006;23:1567-74.

\section{Additional references \\ Andrade 1995}

Andrade SE, Walker AM, Gottlieb LK, Hollenberg NK, Testa MA, Saperia GM, et al. Discontinuation of antihyperlipidemic drugs - do rates reported in clinical trials reflect rates in primary care settings?. New England Journal of Medicine 1995;332(17):1125-31.

\section{Azad Khan 1977}

Azad Khan AK, Piris J, Truelove SC. An experiment to determine the active therapeutic moiety of sulfasalazine. Lancet 1977;2(8044):892-5.

\section{Beaulieu 2009}

Beaulieu DB Schwartz DA. Medication persistence in patients with ulcerative colitis: meeting the challenges and improving patient outcomes CME. MedScape CME Gastroenterology Posted 12/22/2009.

\section{Brixner 2007}

Brixner D, Magowan S, Accortt N. Evaluation of prescription refill patterns based on daily dosing regimen and pill load for calcium channel blockers. Academy of Managed Care Pharmacy Annual Meeting. San Diego, CA, 2007.

\section{Chan 1983}

Chan RP, Pope DJ, Gilbert AP, Sacra PJ, Baron JH, LennardJones JE. Studies of two novel sulfasalazine analogs, ipsalazide and balsalazide. Digestive Diseases and Sciences 1983;28:609-15.

\section{Das 1973}

Das KM, Eastwood MA, McManus JPA, Sircus W. Adverse reactions during salicylazosulfapyridine therapy and the relation with drug metabolism and acetylator phenotype. New England Journal of Medicine 1973;289:491-5.

\section{Dew 1982a}

Dew MJ, Hughes PJ, Lee MG, Evans BK, Rhodes J. An oral preparation to release drugs in the human colon. British Journal of Clinical Pharmacology 1982;14:405-8.

\section{Ediger 2007}

Ediger JP, Walker JR, Graff L, Lix L, Clara I, Rawsthorne P, et al. Predictors of medication adherence in inflammatory bowel disease. American Journal of Gastroenterology 2007;102(7):1417-26. 


\section{Fleig 1988}

Fleig WE, Laudage G, Sommer H, Wellmann W, Stange EF, Riemann J. Prospective, randomized, double-blind comparison of benzalazine and sulfasalazine in the treatment of active ulcerative colitis. Digestion 1988;40(3):173-80.

\section{Greenfield 1993}

Greenfield SM, Punchard NA, Teare JP, Thompson RP. Review article: the mode of action of the aminosalicylates in inflammatory bowel disease. Alimentary Pharmacology and Therapeutics 1993;7:369-83.

\section{Guyatt 2008}

Guyatt GH, Oxman AD, Vist GE, Kunz R, Falck-Ytter Y, AlonsoCoello P, et al. GRADE: an emerging consensus on rating quality of evidence and strength of recommendations. $B M J$ 2008;336(7650):924-6.

\section{Hardy 1987}

Hardy JG, Healey JNC, Reynolds JR. Evaluation of an entericcoated delayed-release 5-aminosalicylic acid tablet in patients with inflammatory bowel disease. Alimentary Pharmacology and Therapeutics 1987;1:273-80.

\section{Higgins 2003}

Higgins JPT, Thompson SG, Deeks JJ, Altman DG. Measuring inconsistency in meta-analysis. BMJ 2003;327:557-60.

\section{Higgins 2011}

Higgins JPT, Altman DG, Sterne JAC (editors). Chapter 8: Assessing risk of bias in included studies. In: Higgins JPT, Green S editor(s). Cochrane Handbook for Systematic Reviews of Interventions Version 5.1.0 (updated March 2011). The Cochrane Collaboration, 2011. Available from www.cochranehandbook.org.

\section{Ireland 1988b}

Ireland A, Jewell DP. Olsalazine in patients intolerant of sulfasalazine. Scandinavian Journal of Gastroenterology 1988;23(suppl 148):101-3.

\section{Jarnerot 1996}

Jarnerot G. Withdrawal rates because of diarrhoea in Dipentumtreated patients with ulcerative colitis are low when Dipentum is taken with food and dose titrated [abstract]. Gastroenterology 1996;110:A932.

\section{Kane 2001}

Kane SV, Cohen RD, Aikens JE, Hanauer SB. Prevalence of nonadherence with maintenance mesalamine in quiescent ulcerative colitis. American Journal of Gastroenterology 2001;96(10):2929-33.

\section{Kane 2003b}

Kane S, Huo D, Aikens J, Hanauer S. Medication nonadherence and the outcomes of patients with quiescent ulcerative colitis. American Journal of Medicine 2003;114(1):39-43.

\section{Kane 2006}

Kane SV. Systematic review: adherence issues in the treatment of ulcerative colitis. Alimentary Pharmacology and Therapeutics 2006;23(5):577-85

\section{Kane 2008b}

Kane SV, Brixner D, Rubin DT, Sewitch MJ. The challenge of compliance and persistence: focus on ulcerative colitis. Journal of Managed Care Pharmacy 2008;14(1 Suppl A):s2-12.

\section{Kjaergaard 1989}

Kjaergaard N, Ambrosius Christensen L, Lauritsen JG, Rasmussen N, Honore Hansen S. Effects of mesalazine substitution on salicylazosulfapyridine-induced seminal abnormalities in men with ulcerative colitis. Scandinavian Journal of Gastroenterology 1989;24:891-6.

\section{Klotz 1980}

Klotz U, Maier K, Fischer C, Heinkel K. Therapeutic efficacy of sulfasalazine and its metabolites in patients with ulcerative colitis and Crohn's disease. New England Journal of Medicine 1980;303:1499-502.

\section{Levy 1999}

Levy RL, Feld AD. Increasing patient adherence to gastroenterology treatment and prevention regimens. American Journal of Gastroenterology 1999;94(7):1733-42.

\section{Magowan 2006}

Magowan S, Kane S, Lange JL. 5-ASA prescription refill rates for ulcerative colitis are independent of formulation and dosing regimens. American Journal of Gastroenterology 2006;101:S447.

\section{Misiewitz 1965}

Misiewitz JJ, Lennard-Jones JE, Connell AM, Baron JH, Jones FA. Controlled trial of sulfasalazine in maintenance therapy for ulcerative colitis. Lancet 1965;1:185-8.

\section{Myers 1987}

Myers B, Evans DNW, Rhodes J, Evans BK, Hughes BR, Lee MG, et al. Metabolism and urinary excretion of 5-aminosalicylic acid in healthy volunteers when given intravenously or released for absorption at different sites in the gastrointestinal tract. Gut 1987;28:196-200.

\section{Nielsen 1982}

Nielsen $\mathrm{OH}$. Sulfasalazine intolerance: a retrospective study of the reasons for discontinuing treatment with sulfasalazine in patients with chronic inflammatory bowel disease. Scandinavian Journal of Gastroenterology 1982;17:389-93.

\section{Nielsen 1983}

Nielsen $\mathrm{OH}$, Bondesen S. Kinetics of 5-aminosalicylic acid after jejunal instillation in man. British Journal of Clinical Pharmacology 1983;16:738-40.

\section{Peppercorn 1972}

Peppercorn MA, Goldman P. The role of intestinal bacteria in the metabolism of salicylazo-sulfapyridine. Journal of Pharmacology and Experimental Therapeutics 1972;181:555-62. 


\section{Rao 1987}

Rao SS, Cann PA, Holdsworth CD. Clinical experience of the tolerance of mesalazine and olsalazine in patients intolerant of sulfasalazine. Scandinavian Journal of Gastroenterology 1987;22:332-6.

\section{Rasmussen 1982}

Rasmussen SN, Bondesen S, Hvidberg EF, Hansen SH, Binder V, Halskou S, et al. 5-aminosalicylic acid in a slow-release preparation: bioavailability, plasma level, and excretion in humans. Gastroenterology 1982;83:1062-70.

\section{Riley 1987}

Riley SA, Lecarpentier J, Mini V, Goodman JJ, Mandal BK, Turnberg LA. Sulfasalazine induced seminal abnormalities in ulcerative colitis: result of mesalazine substitution. Gut 1987;28:1008-12.

\section{Sandborn 2002a}

Sandborn WJ. Rational selection of oral 5-aminosalicylate formulations and prodrugs for the treatment of ulcerative colitis. American Journal of Gastroenterology 2002;97(12):2939-41.

\section{Sandborn 2002b}

Sandborn WJ, Hanauer SB, Buch A. Comparable systemic absorption of 5-ASA and N-AC-5-ASA from U.S. Asacol and Colazal. American Journal of Gastroenterology 2002;97:S263.

\section{Sandborn 2002c}

Sandborn WJ, Hanauer SB. The pharmacokinetic profiles of oral 5ASA formulations used in the management of ulcerative colitis: A systematic review. American Journal of Gastroenterology 2002;97:S269.

\section{Sandborn 2003}

Sandborn WJ, Hanauer SB. Systematic review: the pharmacokinetic profiles of oral mesalazine formulations and mesalazine pro-drugs used in the management of ulcerative colitis. Alimentary Pharmacology and Therapeutics 2003;17(1):29-42.

\section{Schroeder 1972}

Schroeder H, Campbell DES. Absorption, metabolism, and excretion of salicylazosulfapyridine in man. Clinical Pharmacology and Therapeutics 1972;13:539-51.

\section{Schünemann 2011}

Schünemann HJ, Oxman AD, Vist GE, Higgins JPT, Deeks JJ, Glasziou P, et al. Chapter 12: Interpreting results and drawing conclusions. In: Higgins JPT, Green S editor(s). Cochrane Handbook for Systematic Reviews of Interventions Version 5.1.0 (updated March 2011). The Cochrane Collaboration, 2011. Available from www.cochrane-handbook.org.

\section{Shale 2003}

Shale MJ, Riley SA. Studies of compliance with delayedrelease mesalazine therapy in patients with inflammatory bowel disease. Alimentary Pharmacology and Therapeutics 2003;18(2):191-8.

\section{Svartz 1942}

Svartz N. Salazopyrin, a new sulfanilamide preparation: A. Therapeutic reults in rheumatic polyarthritis. B. Therapeutic results in ulcerative colitis. C. Toxic manifestations in treatment with sulfanilamide preparation. Acta Medica Scandinavica 1942;110:557-90.

\section{Truelove 1955}

Truelove SC, Witts LJ. Cortisone in ulcerative colitis: Final report on a therapeutic trial. British Medical Journal 1955;4947:1041-8.

\section{Truelove 1959}

Truelove SC, Witts LJ. Cortisone and corticotrophin in ulcerative colitis. British Medical Journal 1959;i:387-94.

\section{Van Hees 1980}

Van Hees PAM, Bakker JH, Tongeren JHM. Effect of sulfapyridine, 5-aminosalicylic acid, and placebo in patients with idiopathic proctitis: a study to determine the active therapeutic moiety of sulfasalazine. Gut 1980;21:632-5.

\section{Willoughby 1982}

Willoughby CP, Aronson JK, Agback H, Bodin NO, Truelove SC. Distribution and metabolism in healthy volunteers of disodium azodisalicylate, a potential therapeutic agent for ulcerative colitis. Gut 1982;23:1081-7.

\section{References to other published versions of this review Feagan 2012}

Feagan BG, MacDonald JK. Oral 5-aminosalicylic acid for maintenance of remission in ulcerative colitis. Cochrane Database of Systematic Reviews 2012, Issue 10. [DOI: 10.1002/14651858.CD000544.pub3]

\section{Sutherland 1993}

Sutherland LR, May GR, Shaffer EA. Sulfasalazine revisited: a meta-analysis of 5-aminosalicylic acid in the treatment of ulcerative colitis. Annals of Internal Medicine 1993;118:540-9.

\section{Sutherland 1997}

Sutherland LR, Roth DE, Beck PL. Alternatives to sulfasalazine: A meta-analysis of 5-ASA in the treatment of ulcerative colitis. Inflammatory Bowel Diseases 1997;3:65-78.

\section{Sutherland 2006}

Sutherland LR, MacDonald JK. Oral 5-aminosalicylic acid for maintenance of remission in ulcerative colitis. Cochrane Database of Systematic Reviews 2006, Issue 2. [DOI: 10.1002/14651858.CD000544.pub2]

* Indicates the major publication for the study 
CHARACTERISTICS OF STUDIES

Characteristics of included studies [ordered by study ID]

Andreoli 1987

Methods Randomized, double-bind trial comparing 5-ASA and SASP. Allocation of drugs was performed using a table of random numbers

\begin{tabular}{ll}
\hline Participants & Patients with ulcerative colitis in remission $(\mathrm{N}=13)$ \\
\hline Interventions & 5-ASA, $0.75 \mathrm{~g} /$ day $(\mathrm{n}=7)$, or SASP, $1.5 \mathrm{~g} / \mathrm{day}(\mathrm{n}=6)$ for a duration of 12 months \\
\hline Outcomes & $\begin{array}{l}\text { The development of a new acute phase within } 12 \text { months from the beginning of the survey was consid- } \\
\text { ered a negative result }\end{array}$ \\
\hline Notes & Abstract
\end{tabular}

\section{Risk of bias}

\begin{tabular}{lll}
\hline Bias & Authors' judgement & Support for judgement \\
\hline $\begin{array}{l}\text { Random sequence genera- } \\
\text { tion (selection bias) }\end{array}$ & Low risk & Table of random numbers \\
\hline $\begin{array}{l}\text { Allocation concealment } \\
\text { (selection bias) }\end{array}$ & Unclear risk & Not described \\
\hline $\begin{array}{l}\text { Blinding (performance } \\
\text { bias and detection bias) } \\
\text { All outcomes }\end{array}$ & Low risk & Double-blind \\
\hline $\begin{array}{l}\text { Incomplete outcome data } \\
\text { (attrition bias) } \\
\text { All outcomes }\end{array}$ & Unclear risk & Not described \\
\hline $\begin{array}{l}\text { Selective reporting (re- } \\
\text { porting bias) }\end{array}$ & Unclear risk & Not described \\
\hline \begin{tabular}{l} 
Other bias \\
\hline
\end{tabular} & Unclear risk & Not described \\
\hline
\end{tabular}

\section{Ardizzone 1995}

\begin{tabular}{ll}
\hline Methods & $\begin{array}{l}\text { Single-center, randomized, double-blind comparison of Claversal and SASP. Clinical, endoscopic and } \\
\text { histological examinations were performed at entry, after } 6 \text { months, and after } 12 \text { months }\end{array}$ \\
\hline Participants & $\begin{array}{l}\text { Patients, aged } 18 \text { to } 61 \text { years, with clinical and endoscopically quiescent ulcerative colitis, who had an } \\
\text { episode of active disease requiring systemic corticosteroids at least once in the previous } 12 \text { months ( } \mathrm{N} \\
=\end{array}$ \\
\hline Interventions & $\begin{array}{l}\text { 5-ASA (Claversal), } 1 \mathrm{~g} \text { daily }(\mathrm{n}=44) \text {, or SASP, } 2 \mathrm{~g} \text { daily }(\mathrm{n}=44) \text {, for } 1 \text { year. Topical corticosteroids were } \\
\text { permitted for short-term treatment of mild distal relapses }\end{array}$ \\
\hline Outcomes & $\begin{array}{l}\text { Relapse of disease was defined as the appearance of bloody diarrhea with endoscopic signs of inflam- } \\
\text { mation requiring systemic steroids (major relapse). "Minor relapses" were defined as those requiring a } \\
\text { few days of topical corticosteroids. The number of withdrawals due to adverse effects was also report- } \\
\text { ed }\end{array}$
\end{tabular}


Ardizzone 1995 (Continued)

Notes

\section{Risk of bias}

\begin{tabular}{|c|c|c|}
\hline Bias & Authors' judgement & Support for judgement \\
\hline $\begin{array}{l}\text { Random sequence genera- } \\
\text { tion (selection bias) }\end{array}$ & Unclear risk & Not described \\
\hline $\begin{array}{l}\text { Allocation concealment } \\
\text { (selection bias) }\end{array}$ & Unclear risk & Not described \\
\hline $\begin{array}{l}\text { Blinding (performance } \\
\text { bias and detection bias) } \\
\text { All outcomes }\end{array}$ & Low risk & Double-blind \\
\hline $\begin{array}{l}\text { Incomplete outcome data } \\
\text { (attrition bias) } \\
\text { All outcomes }\end{array}$ & Low risk & $\begin{array}{l}\text { Drop-outs balanced across intervention groups with similar reasons for with- } \\
\text { drawal }\end{array}$ \\
\hline $\begin{array}{l}\text { Selective reporting (re- } \\
\text { porting bias) }\end{array}$ & Low risk & Expected outcomes reported \\
\hline Other bias & Low risk & The study appears to be free of other sources of bias \\
\hline
\end{tabular}

\section{Ardizzone 1999}

\begin{tabular}{|c|c|c|}
\hline Methods & \multicolumn{2}{|c|}{ Single-center, randomized, double-blind, placebo-controlled trial } \\
\hline Participants & \multicolumn{2}{|c|}{$\begin{array}{l}\text { Adult patients (aged } 18 \text { to } 75 \text { years) with confirmed diagnosis of intermittent chronic ulcerative colitis } \\
\text { in stable clinical, endoscopic and histological remission for at least one year }(\mathrm{N}=112)\end{array}$} \\
\hline Interventions & \multicolumn{2}{|c|}{ Asacol $1.2 \mathrm{~g} /$ day $(\mathrm{n}=54)$ or identical placebo $(\mathrm{n}=58)$ for one year } \\
\hline Outcomes & \multicolumn{2}{|c|}{$\begin{array}{l}\text { Primary outcome was maintenance of remission. Relapse was defined as increased stool frequency } \\
\text { with blood or mucus and evidence of disease activity on sigmoidoscopy. Secondary outcomes: adverse } \\
\text { events, compliance }\end{array}$} \\
\hline \multicolumn{3}{|l|}{ Notes } \\
\hline \multicolumn{3}{|l|}{ Risk of bias } \\
\hline Bias & Authors' judgement & Support for judgement \\
\hline $\begin{array}{l}\text { Random sequence genera- } \\
\text { tion (selection bias) }\end{array}$ & Unclear risk & Not described \\
\hline $\begin{array}{l}\text { Allocation concealment } \\
\text { (selection bias) }\end{array}$ & Unclear risk & Not described \\
\hline $\begin{array}{l}\text { Blinding (performance } \\
\text { bias and detection bias) } \\
\text { All outcomes }\end{array}$ & Low risk & $\begin{array}{l}\text { Double-blind, identical placebo, drugs were provided in identical blister pack- } \\
\text { ages }\end{array}$ \\
\hline
\end{tabular}


Ardizzone 1999 (Continued)

Incomplete outcome data Low risk Drop-outs balanced across intervention groups with similar reasons for with(attrition bias) drawal

All outcomes

\begin{tabular}{lll}
$\begin{array}{l}\text { Selective reporting (re- } \\
\text { porting bias) }\end{array}$ & Low risk & Expected outcomes were reported \\
\hline Other bias & Low risk & The study appears to be free of other sources of bias \\
\hline
\end{tabular}

\section{Courtney 1992}

\begin{tabular}{ll}
\hline Methods & Randomized single-blind trial \\
\hline Participants & Adult patients ( 16 to 75 years) with ulcerative colitis in remission $(\mathrm{N}=100)$ \\
\hline Interventions & Olsalazine $1.0 \mathrm{~g} /$ day $(\mathrm{n}=50)$ or mesalazine (Asacol) $1.2 \mathrm{~g} / \mathrm{day}(\mathrm{n}=50)$ for 12 months \\
\hline Outcomes & $\begin{array}{l}\text { Remission was defined as absence of symptoms or the presence of only mild stable symptoms of coli- } \\
\text { tis. Relapse was defined as development of new symptoms of colitis sufficiently severe enough to war- } \\
\text { rant the introduction of systemic steroid therapy (by a blinded investigator). Adverse events }\end{array}$
\end{tabular}

Notes

\section{Risk of bias}

\begin{tabular}{lll}
\hline Bias & Authors' judgement & Support for judgement \\
\hline $\begin{array}{l}\text { Random sequence genera- } \\
\text { tion (selection bias) }\end{array}$ & Low risk & $\begin{array}{l}\text { Patients were randomly allocated to treatment groups by means of a comput- } \\
\text { er-generated code }\end{array}$ \\
\hline $\begin{array}{l}\text { Allocation concealment } \\
\text { (selection bias) }\end{array}$ & Unclear risk & Not described \\
\hline
\end{tabular}

Blinding (performance High risk Single-blind (observer)

bias and detection bias)

All outcomes

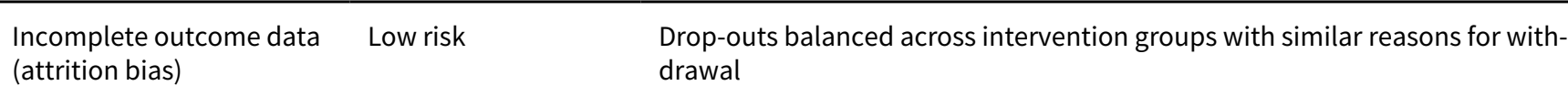

All outcomes drawal

\begin{tabular}{lll}
\hline $\begin{array}{l}\text { Selective reporting (re- } \\
\text { porting bias) }\end{array}$ & Low risk & Expected outcomes were reported \\
\hline Other bias & Low risk & The study appears to be free of other sources of bias \\
\hline
\end{tabular}

\section{D'Haens 2012}

\begin{tabular}{ll} 
Methods & $\begin{array}{l}\text { Multi-centre, double-blind, double-dummy, randomized, non-inferiority trial comparing the efficacy } \\
\text { and safety of once daily MMX mesalamine ( } 2.4 \mathrm{~g} / \text { day) with twice daily mesalamine (Asacol, } 1.6 \mathrm{~g} / \text { day) in } \\
\text { patients with ulcerative colitis who were in endoscopic remission }\end{array}$ \\
\hline
\end{tabular}


D'Haens 2012 (Continued)

Participants

Adult patients ( $\geq 18$ years) with a diagnosis of UC (confirmed by histology) that was considered to be in remission for $\geq 30$ days on a stable dose of mesalamine $(\leq 2.4 \mathrm{~g} /$ day) or the equivalent dose of sulfasalazine ( $\leq 6.2 \mathrm{~g}$ / day), with an endoscopy score of $\leq 1$; and had a combined symptom score (stool frequency and rectal bleeding) of $\leq 1$. All patients were to have had experienced at least one acute flare of UC (defined as a documented episode of increased bowel frequency with rectal bleeding for which UC therapy was intensified) in the past 12 months, with at least two acute flares in their medical history ( $\mathrm{N}$ $=826)$

\begin{tabular}{|c|c|}
\hline Interventions & $\begin{array}{l}\text { MMX mesalamine }(2.4 \mathrm{~g} / \text { day) dosed once daily }(n=415) \text { versus Asacol }(1.6 \mathrm{~g} / \text { day }) \text { dosed twice daily }(n= \\
\text { 411) for } 6 \text { months }\end{array}$ \\
\hline Outcomes & $\begin{array}{l}\text { Primary outcome was endoscopic remission at } 6 \text { months defined as a modified UC-DAI endoscopy sub- } \\
\text { score of } \leq 1 \text { point. Secondary outcomes included: maintenance of mucosal healing with no or mild } \\
\text { symptoms (combined modified UC-DAI-defined stool frequency and rectal bleeding subscores of } \leq 1 \\
\text { point) at } 6 \text { months; time to relapse (relapse was defined as withdrawal due to lack of efficacy), mea- } \\
\text { sured from the date of randomization to the date the patient withdrew due to relapse; the modified UC- } \\
\text { DAI score and its components (rectal bleeding, stool frequency, endoscopy, and Physician's Global As- } \\
\text { sessment scores); and safety and tolerability of study treatments }\end{array}$ \\
\hline
\end{tabular}

Notes

\section{Risk of bias}

\begin{tabular}{lll}
\hline Bias & Authors' judgement & Support for judgement \\
\hline $\begin{array}{l}\text { Random sequence genera- } \\
\text { tion (selection bias) }\end{array}$ & Unclear risk & Not described \\
\hline $\begin{array}{l}\text { Allocation concealment } \\
\text { (selection bias) }\end{array}$ & Low risk & $\begin{array}{l}\text { The randomization was performed centrally via an interactive voice response } \\
\text { system }\end{array}$ \\
\hline $\begin{array}{l}\text { Blinding (performance } \\
\text { bias and detection bias) } \\
\text { All outcomes }\end{array}$ & Low risk & Double-blind, double-dummy (matched placebos) \\
\hline $\begin{array}{l}\text { Incomplete outcome data } \\
\text { (attrition bias) } \\
\text { All outcomes }\end{array}$ & Low risk & $\begin{array}{l}\text { Drop-outs balanced across intervention groups with similar reasons for with- } \\
\text { drawal }\end{array}$ \\
\hline $\begin{array}{l}\text { Selective reporting (re- } \\
\text { porting bias) }\end{array}$ & Low risk & All expected outcomes reported \\
\hline \begin{tabular}{l} 
Other bias \\
\hline
\end{tabular} & Low risk & The study appears to be free of other sources of bias \\
\hline
\end{tabular}

\section{Deventer 2001}

\begin{tabular}{ll}
\hline Methods & Randomized, multi-center (46), single-blind trial \\
\hline Participants & Patients with quiescent ulcerative colitis for more than 1 month but less than 3 years $(\mathrm{N}=388)$ \\
\hline Interventions & Asacol $2 \mathrm{~g} /$ day $(\mathrm{n}=124)$, Asacol $3.2 \mathrm{~g} /$ day $(\mathrm{n}=138)$, or Salofalk $2 \mathrm{~g} /$ day $(\mathrm{n}=126)$ for 18 months \\
\hline Outcomes & Primary outcome: remission at 18 months \\
\hline Notes & Abstract publication \\
\hline
\end{tabular}


Deventer 2001 (Continued)

\section{Risk of bias}

\begin{tabular}{|c|c|c|}
\hline Bias & Authors' judgement & Support for judgement \\
\hline $\begin{array}{l}\text { Random sequence genera- } \\
\text { tion (selection bias) }\end{array}$ & Unclear risk & Not described \\
\hline $\begin{array}{l}\text { Allocation concealment } \\
\text { (selection bias) }\end{array}$ & Unclear risk & Not described \\
\hline $\begin{array}{l}\text { Blinding (performance } \\
\text { bias and detection bias) } \\
\text { All outcomes }\end{array}$ & High risk & $\begin{array}{l}\text { Single-blind. Sigmoidoscopies were videotaped at study entry and after } 9 \text { and } \\
18 \text { months of treatment and blindly scored for disease activity by } 2 \text { gastroen- } \\
\text { terologists }\end{array}$ \\
\hline $\begin{array}{l}\text { Incomplete outcome data } \\
\text { (attrition bias) } \\
\text { All outcomes }\end{array}$ & Unclear risk & Drop-outs and reasons for withdrawal were not described \\
\hline $\begin{array}{l}\text { Selective reporting (re- } \\
\text { porting bias) }\end{array}$ & Unclear risk & Secondary outcomes were not described \\
\hline Other bias & Unclear risk & Abstract publication \\
\hline
\end{tabular}

Dew 1983a

\begin{tabular}{|c|c|}
\hline Methods & Randomized, double-blind, double-dummy trial \\
\hline Participants & $\begin{array}{l}\text { Adult patients }(\mathrm{N}=67) \text { with ulcerative colitis in remission ( } 3 \text { or less stools daily without blood or slime } \\
\text { and normal sigmoidoscopic findings) }\end{array}$ \\
\hline Interventions & $\begin{array}{l}\text { 5-ASA (Asacol mean dose } 2.7 \mathrm{~g} / \mathrm{day} \text {; range: } 2.4 \text { to } 4.4 \mathrm{~g} / \mathrm{day} ; \mathrm{n}=32 \text { ) or SASP (mean dose } 2.3 \mathrm{~g} / \mathrm{day} \text {; range } \\
2 \text { to } 4 \mathrm{~g} / \text { day; } \mathrm{n}=25 \text { ) for } 6 \text { months }\end{array}$ \\
\hline Outcomes & $\begin{array}{l}\text { Relapse defined as recurrence of symptoms with sigmoidoscopic changes including contact or sponta- } \\
\text { neous mucosal hemorrhages, pus or ulceration }\end{array}$ \\
\hline
\end{tabular}

\section{Risk of bias}

\begin{tabular}{|c|c|c|}
\hline Bias & Authors' judgement & Support for judgement \\
\hline $\begin{array}{l}\text { Random sequence genera- } \\
\text { tion (selection bias) }\end{array}$ & Unclear risk & Not described \\
\hline $\begin{array}{l}\text { Allocation concealment } \\
\text { (selection bias) }\end{array}$ & Unclear risk & Not described \\
\hline $\begin{array}{l}\text { Blinding (performance } \\
\text { bias and detection bias) } \\
\text { All outcomes }\end{array}$ & Low risk & Double-blind, double-dummy (identical placebo tablets) \\
\hline $\begin{array}{l}\text { Incomplete outcome data } \\
\text { (attrition bias) } \\
\text { All outcomes }\end{array}$ & Unclear risk & $\begin{array}{l}10 \text { of } 67 \text { patients withdrew. } 4 \text { SASP patients withdrew due to headaches. We do } \\
\text { not know which groups the other } 6 \text { patients belonged to }\end{array}$ \\
\hline
\end{tabular}


Dew 1983a (Continued)

Selective reporting (re- Low risk $\quad$ Expected outcomes were reported
porting bias)

Other bias Low risk The study appears to be free of other sources of bias

\section{Dignass 2009}

\begin{tabular}{ll}
\hline Methods & Multicenter, randomized, investigator-blinded, non-inferiority trial \\
\hline Participants & $\begin{array}{l}\text { Adult patients }(\geq 18 \text { years) with an established diagnosis of ulcerative colitis and in clinical remission } \\
(\text { UC-DIA }<2 \text { at entry) }(\mathrm{N}=362)\end{array}$ \\
\hline Interventions & Mesalamine (Pentasa) $2 \mathrm{~g}$ once daily $(\mathrm{n}=169)$ or $1 \mathrm{~g}$ twice daily $(\mathrm{n}=184)$ for $12 \mathrm{months}$ \\
\hline Outcomes & $\begin{array}{l}\text { The primary outcome was maintenance of clinical remission at } 12 \text { months. Secondary outcomes: } \\
\text { time to relapse, UC-DAl total and subscores, adherence, global acceptability of treatment and adverse } \\
\text { events }\end{array}$ \\
\hline Notes & $\begin{array}{l}\text { Six patients in the OD group and } 3 \text { in the BID group were excluded from the ITT analysis for major entry } \\
\text { criteria violation. Adherence was self-reported by patients using a VAS scale }\end{array}$
\end{tabular}

\section{Risk of bias}

\begin{tabular}{lll}
\hline Bias & Authors' judgement & Support for judgement \\
\hline $\begin{array}{l}\text { Random sequence genera- } \\
\text { tion (selection bias) }\end{array}$ & Unclear risk & Not described \\
\hline $\begin{array}{l}\text { Allocation concealment } \\
\text { (selection bias) }\end{array}$ & Low risk & $\begin{array}{l}\text { Patients were randomized centrally using an interactive voice response sys- } \\
\text { tem }\end{array}$ \\
\hline $\begin{array}{l}\text { Blinding (performance } \\
\text { bias and detection bias) } \\
\text { All outcomes }\end{array}$ & High risk & Single-blind (investigator), outcomes assessed by blinded investigator \\
\hline $\begin{array}{l}\text { Incomplete outcome data } \\
\text { (attrition bias) } \\
\text { All outcomes }\end{array}$ & Low risk & $\begin{array}{l}\text { Drop-outs balanced across intervention groups with similar reasons for with- } \\
\text { drawal }\end{array}$ \\
\hline $\begin{array}{l}\text { Selective reporting (re- } \\
\text { porting bias) }\end{array}$ & Low risk & All expected outcomes reported \\
\hline \begin{tabular}{l} 
Other bias \\
\hline
\end{tabular} & Low risk & The study appears to be free of other sources of bias \\
\hline
\end{tabular}

Fockens 1995

\begin{tabular}{ll}
\hline Methods & Multicenter, randomized, double-blind trial \\
\hline Participants & $\begin{array}{l}\text { Adult patients (18 to } 75 \text { years) with ulcerative colitis in remission for at least and month and up to } 3 \\
\text { years }(\mathrm{N}=169)\end{array}$ \\
\hline Interventions & Mesalazine (Pentasa) $1.5 \mathrm{~g} /$ day $(\mathrm{n}=87)$ or $3.0 \mathrm{~g} / \mathrm{day}(\mathrm{n}=82)$ for 12 months \\
\hline
\end{tabular}


Fockens 1995 (Continued)

Outcomes

Primary outcome: maintenance of remission at 12 months. Secondary outcomes: serious adverse events

Notes

\section{Risk of bias}

\begin{tabular}{|c|c|c|}
\hline Bias & Authors' judgement & Support for judgement \\
\hline $\begin{array}{l}\text { Random sequence genera- } \\
\text { tion (selection bias) }\end{array}$ & Low risk & $\begin{array}{l}\text { Computer-generated: Randomization was performed with the SAS statistical } \\
\text { package in balanced blocks of } 10 \text { patients }\end{array}$ \\
\hline $\begin{array}{l}\text { Allocation concealment } \\
\text { (selection bias) }\end{array}$ & Unclear risk & Not described \\
\hline $\begin{array}{l}\text { Blinding (performance } \\
\text { bias and detection bias) } \\
\text { All outcomes }\end{array}$ & Low risk & $\begin{array}{l}\text { Double-blind: placebo tablets were identical to Pentasa tablets in appearance, } \\
\text { weight and taste }\end{array}$ \\
\hline $\begin{array}{l}\text { Incomplete outcome data } \\
\text { (attrition bias) } \\
\text { All outcomes }\end{array}$ & Low risk & $\begin{array}{l}\text { Drop-outs balanced across intervention groups with similar reasons for with- } \\
\text { drawal }\end{array}$ \\
\hline $\begin{array}{l}\text { Selective reporting (re- } \\
\text { porting bias) }\end{array}$ & Low risk & Expected outcomes were reported \\
\hline Other bias & Low risk & The study appears to be free of other sources of bias \\
\hline
\end{tabular}

Giaffer 1992a

\begin{tabular}{|c|c|c|}
\hline Methods & \multicolumn{2}{|c|}{ Multicenter, randomized, double-blind trial } \\
\hline Participants & \multicolumn{2}{|c|}{$\begin{array}{l}\text { Patients with ulcerative colitis in clinical (minimal or no symptoms) and sigmoidoscopic (non-friable } \\
\text { mucosa) remission }(\mathrm{N}=133)\end{array}$} \\
\hline Interventions & \multicolumn{2}{|c|}{ Balsalazide $2 \mathrm{~g} /$ day $(\mathrm{n}=65)$ or $4 \mathrm{~g} /$ day $(\mathrm{n}=68)$} \\
\hline Outcomes & \multicolumn{2}{|c|}{$\begin{array}{l}\text { Relapse at } 12 \text { months and adverse events. Symptomatic relapse was defined as recurrence of previous } \\
\text { symptoms with increased stool frequency and associated blood }\end{array}$} \\
\hline \multicolumn{3}{|l|}{ Notes } \\
\hline \multicolumn{3}{|l|}{ Risk of bias } \\
\hline Bias & Authors' judgement & Support for judgement \\
\hline $\begin{array}{l}\text { Random sequence genera- } \\
\text { tion (selection bias) }\end{array}$ & Unclear risk & Not described \\
\hline $\begin{array}{l}\text { Allocation concealment } \\
\text { (selection bias) }\end{array}$ & Unclear risk & Not described \\
\hline $\begin{array}{l}\text { Blinding (performance } \\
\text { bias and detection bias) } \\
\text { All outcomes }\end{array}$ & Low risk & $\begin{array}{l}\text { Double-blind: The placebo and trial drug were in identical hard gelatin cap- } \\
\text { sules }\end{array}$ \\
\hline
\end{tabular}


Giaffer 1992a (Continued)

\begin{tabular}{|c|c|c|}
\hline $\begin{array}{l}\text { Incomplete outcome data } \\
\text { (attrition bias) }\end{array}$ & Low risk & $\begin{array}{l}\text { Drop-outs balanced across intervention groups with similar reasons for with- } \\
\text { drawal }\end{array}$ \\
\hline
\end{tabular}

All outcomes

\begin{tabular}{lll}
$\begin{array}{l}\text { Selective reporting (re- } \\
\text { porting bias) }\end{array}$ & Low risk & Expected outcomes were reported \\
\hline Other bias & Low risk & The study appears to be free of other sources of bias \\
\hline
\end{tabular}

\section{Green 1992}

\begin{tabular}{ll}
\hline Methods & Multicenter, randomized, double-blind trial \\
\hline Participants & $\begin{array}{l}\text { Adult patients (aged } 19 \text { to } 78 \text { years) with ulcerative colitis in clinical and sigmoidoscopic remission ( } \mathrm{N}= \\
108)\end{array}$ \\
\hline Interventions & Balsalazide $3 \mathrm{~g} /$ day $(\mathrm{n}=54)$ or $6 \mathrm{~g} /$ day $(\mathrm{n}=54)$ for 12 months \\
\hline Outcomes & $\begin{array}{l}\text { Primary outcome: relapse at } 12 \text { months. Secondary: adverse events. Relapse was defined on clinical }(7 \\
\text { days of increased stool frequency with or without blood and mucus) } \\
\text { or spontaneous hemmorhage }\end{array}$ \\
\hline Notes & \\
\hline
\end{tabular}

\section{Risk of bias}

\begin{tabular}{lll}
\hline Bias & Authors' judgement & Support for judgement \\
\hline $\begin{array}{l}\text { Random sequence genera- } \\
\text { tion (selection bias) }\end{array}$ & Unclear risk & Not described \\
\hline $\begin{array}{l}\text { Allocation concealment } \\
\text { (selection bias) }\end{array}$ & Unclear risk & Not described \\
\hline $\begin{array}{l}\text { Blinding (performance } \\
\text { bias and detection bias) } \\
\text { All outcomes }\end{array}$ & Unclear risk & Double-blind. Dummy capsules were not described in detail \\
\hline $\begin{array}{l}\text { Incomplete outcome data } \\
\text { (attrition bias) } \\
\text { All outcomes }\end{array}$ & Low risk & $\begin{array}{l}\text { Drop-outs balanced across intervention groups with similar reasons for with- } \\
\text { drawal }\end{array}$ \\
\hline $\begin{array}{l}\text { Selective reporting (re- } \\
\text { porting bias) }\end{array}$ & Low risk & Expected outcomes were reported \\
\hline \begin{tabular}{l} 
Other bias \\
\hline
\end{tabular} & Low risk & The study appears to be free of other sources of bias \\
\hline
\end{tabular}

Green 1998

\begin{tabular}{ll}
\hline Methods & Multicenter, randomized, double-blind, double-dummy, parallel group trial \\
\hline Participants & Adult patients (aged 18 to 80 years) with ulcerative colitis in remission $(\mathrm{N}=99)$ \\
\hline
\end{tabular}


Green 1998 (Continued)
Interventions
Balsalazide $3 \mathrm{~g} /$ day $(\mathrm{n}=50)$ or Asacol $1.2 \mathrm{~g} /$ day $(\mathrm{n}=49)$ for 12 months

\begin{tabular}{ll}
\hline Outcomes & The primary outcome was the proportion of patients in remission at 3 and 12 months. Seconadry out- \\
comes: symptom free days, symptoms over three months, adverse events (diary cards)
\end{tabular}

Notes

\section{Risk of bias}

\begin{tabular}{|c|c|c|}
\hline Bias & Authors' judgement & Support for judgement \\
\hline $\begin{array}{l}\text { Random sequence genera- } \\
\text { tion (selection bias) }\end{array}$ & Unclear risk & Not described \\
\hline $\begin{array}{l}\text { Allocation concealment } \\
\text { (selection bias) }\end{array}$ & Unclear risk & Not described \\
\hline $\begin{array}{l}\text { Blinding (performance } \\
\text { bias and detection bias) } \\
\text { All outcomes }\end{array}$ & Low risk & Double-blind, double-dummy, identical placebos \\
\hline $\begin{array}{l}\text { Incomplete outcome data } \\
\text { (attrition bias) } \\
\text { All outcomes }\end{array}$ & Unclear risk & $\begin{array}{l}13 \text { patients }(26 \%) \text { withdrew from the balsalazide group compared to } 5 \text { patients } \\
(11 \%) \text { in the Asacol group }\end{array}$ \\
\hline $\begin{array}{l}\text { Selective reporting (re- } \\
\text { porting bias) }\end{array}$ & Low risk & Expected outcomes were reported \\
\hline Other bias & Low risk & The study appears to be free of other sources of bias \\
\hline
\end{tabular}

Hanauer 1996

\begin{tabular}{ll}
\hline Methods & Multicenter, randomized, double-blind, placebo-controlled trial. Randomization was performed with- \\
in centers by means of codes using specific patient numbers computer-generated for each study site \\
before the study began. In addition to daily diaries, clinical assessments, endoscopy, and lab analyses \\
were performed at entry, 1, 3 and 6 months
\end{tabular}

\begin{tabular}{|c|c|}
\hline Participants & $\begin{array}{l}\text { Patients, aged } 18 \text { to } 75 \text { years, with ulcerative colitis in remission for at least } 1 \text { month, were recruited } \\
\text { from } 17 \text { study sites. The presence of symptoms such as loose stools or abdominal cramps were not rea- } \\
\text { sons for exclusion. Corticosteroid or topical rectal therapy was stopped at least } 1 \text { month before entry ( } \mathrm{N} \\
=264)\end{array}$ \\
\hline Interventions & $\begin{array}{l}\text { Mesalamine (Asacol), } 0.8 \mathrm{~g} / \text { day }(\mathrm{n}=90) \text { or } 1.6 \mathrm{~g} / \mathrm{day}(\mathrm{n}=87) \text { or matched placebo }(\mathrm{n}=87) \text { for } 6 \text { months. } \\
400 \mathrm{mg} \text { tablets were packaged in } 4 \text { bottles, each labelled with the time of day at which its contents } \\
\text { were to be taken. Compliance was monitored by pill count }\end{array}$ \\
\hline Outcomes & $\begin{array}{l}\text { Treatment outcome was rated as either 'success' (maintenance of remission as indicated by endoscop- } \\
\text { ic evaluation) or 'failure' (endoscopic relapse or withdrawal), and was reported on an intention-to-treat } \\
\text { basis }\end{array}$ \\
\hline
\end{tabular}

Notes

\section{Risk of bias}


Hanauer 1996 (Continued)

Random sequence genera- Low risk $\quad$ Computer generated
tion (selection bias)

Allocation concealment Low risk $\quad$ Adequate
(selection bias)

\begin{tabular}{|c|c|c|}
\hline $\begin{array}{l}\text { Blinding (performance } \\
\text { bias and detection bias) } \\
\text { All outcomes }\end{array}$ & Low risk & $\begin{array}{l}\text { The placebo tablets were identical to the mesalamine tablets in odor and ap- } \\
\text { pearance but contained no active ingredients }\end{array}$ \\
\hline
\end{tabular}

\begin{tabular}{|c|c|c|}
\hline $\begin{array}{l}\text { Incomplete outcome data } \\
\text { (attrition bias) } \\
\text { All outcomes }\end{array}$ & Unclear risk & $\begin{array}{l}\text { Seventy-five patients were excluded from the primary efficacy analysis for the } \\
\text { following reasons: failure to meet study entry criteria }(n=36) \text {, noncompliance } \\
\text { with study medication }(n=18) \text {, noncompliance with study procedures }(n=3) \text {, } \\
\text { concomitant medication violation }(n=10) \text {, loss to follow-up }(n=4) \text {, and volun- } \\
\text { tary withdrawal }(n=4) \text {. The numbers of patients excluded were similar in the } \\
\text { three groups }\end{array}$ \\
\hline
\end{tabular}

\begin{tabular}{lll}
\hline $\begin{array}{l}\text { Selective reporting (re- } \\
\text { porting bias) }\end{array}$ & Low risk & Expected outcomes were reported \\
\hline Other bias & Low risk & The study appears to be free of other sources of bias \\
\hline
\end{tabular}

Hawkey 1997

\begin{tabular}{ll}
\hline Methods & $\begin{array}{l}\text { International, multicenter, randomized, double-blind study comparing mesalazine and placebo for } \\
\text { their ability to maintain remission in UC }\end{array}$ \\
\hline Participants & $\begin{array}{l}\text { Patients, age } 18 \text { or above, with ulcerative colitis in remission as defined by normal sigmoidoscopic ap- } \\
\text { pearances with no rectal bleeding during the week before entry. Patients already receiving salicylates } \\
\text { could enter; those receiving oral or rectal steroids could only do so if these were tapered over } 2 \text { weeks } \\
\text { prior to entry ( } \mathrm{N}=323)\end{array}$
\end{tabular}

\begin{tabular}{ll}
\hline Interventions & $\begin{array}{l}\text { One } 400 \mathrm{mg} \text { mesalazine capsule and } 2 \text { placebo capsules four times per day }(\mathrm{n}=99) \text { or } 3 \text { placebo cap- } \\
\text { sules four times per day }(\mathrm{n}=111) \text { for a duration of } 6 \text { months. All capsules were identical }\end{array}$ \\
\hline Outcomes & $\begin{array}{l}\text { The primary efficacy end point was the maintenance of remission. Relapse was defined as a sigmoido- } \\
\text { scopic score of } 1 \text { or more or } 3 \text { consecutive days of rectal bleeding caused by UC or liquid stools for } 1 \\
\text { week. The number of patients withdrawing due to adverse events was also recorded }\end{array}$
\end{tabular}

Notes The prime objective of this study was the measurement of the efficacy of zileuton $(n=113)$ in UC

\section{Risk of bias}

\begin{tabular}{lll}
\hline Bias & Authors' judgement & Support for judgement \\
\hline $\begin{array}{l}\text { Random sequence genera- } \\
\text { tion (selection bias) }\end{array}$ & Unclear risk & Not described \\
\hline $\begin{array}{l}\text { Allocation concealment } \\
\text { (selection bias) }\end{array}$ & Low risk & $\begin{array}{l}\text { Centralized randomization: Concealed randomization schedules were held } \\
\text { at each participating hospital for code break in the event of serious adverse } \\
\text { events }\end{array}$ \\
\hline $\begin{array}{l}\text { Blinding (performance } \\
\text { bias and detection bias) } \\
\text { All outcomes }\end{array}$ & Low risk & Each capsule was identical in appearance \\
\hline
\end{tabular}


Hawkey 1997 (Continued)

Incomplete outcome data Low risk Drop-outs balanced across intervention groups with similar reasons for with(attrition bias) drawal

All outcomes

\begin{tabular}{lll}
$\begin{array}{l}\text { Selective reporting (re- } \\
\text { porting bias) }\end{array}$ & Low risk & Expected outcomes were reported \\
\hline Other bias & Low risk & The study appears to be free of other sources of bias \\
\hline
\end{tabular}

Hawthorne 2012

\begin{tabular}{ll}
\hline Methods & $\begin{array}{l}\text { Multicenter, single-blind, randomized, non-inferiority study comparing once daily mesalazine to con- } \\
\text { ventionally dosed mesalazine (TID) for maintenance of remission in UC }\end{array}$ \\
\hline Participants & Adult UC patients taking mesalazine or sulphasalazine in remission for $>4$ weeks and $<2$ years ( $\mathrm{N}=213$ ) \\
\hline Interventions & $\begin{array}{l}\text { Asacol } 2.4 \mathrm{~g} / \text { day given once daily }(3 \times 800 \mathrm{mg} \text { tablets; } \mathrm{n}=103 \text { ) versus Asacol } 2.4 \mathrm{~g} / \mathrm{day} \text { given three times } \\
\text { daily }(1 \mathrm{X} 800 \mathrm{mg} \text { tablet } 3 \text { times per day, } \mathrm{n}=110) \text { for one year }\end{array}$ \\
\hline Outcomes & $\begin{array}{l}\text { The primary end-point was the difference between groups in relapse rates over one year. Relapse was } \\
\text { defined as typical symptoms of relapse with a Baron sigmoidoscopy score of } 2 \text { or } 3 . \text { Secondary out- } \\
\text { comes: adherence }\end{array}$ \\
\hline Notes & $\begin{array}{l}\text { Investigator-blinded. Adherence was self-reported by patients. Adherence also was calculated in sub- } \\
\text { group of patients }(\mathrm{n}=58) \text { using "Medication Event Monitoring System (MEMS }{ }^{\circ} \text { " based in a bottle cap } \\
\text { which records each time the bottle is opened }\end{array}$ \\
\hline
\end{tabular}

\section{Risk of bias}

\begin{tabular}{lll}
\hline Bias & Authors' judgement & Support for judgement \\
\hline $\begin{array}{l}\text { Random sequence genera- } \\
\text { tion (selection bias) }\end{array}$ & Unclear risk & Not described \\
\hline $\begin{array}{l}\text { Allocation concealment } \\
\text { (selection bias) }\end{array}$ & Unclear risk & Not described \\
\hline $\begin{array}{l}\text { Blinding (performance } \\
\text { bias and detection bias) } \\
\text { All outcomes }\end{array}$ & High risk & Investigator-blinded, outcomes assessed by blinded investigator \\
\hline $\begin{array}{l}\text { Incomplete outcome data } \\
\text { (attrition bias) } \\
\text { All outcomes }\end{array}$ & Unclear risk & Not described \\
\hline $\begin{array}{l}\text { Selective reporting (re- } \\
\text { porting bias) }\end{array}$ & Low risk & Expected outcomes were reported \\
\hline \begin{tabular}{l} 
Other bias \\
\hline
\end{tabular} & Low risk & The study appears to be free of other sources of bias \\
\hline
\end{tabular}


Ireland 1988

Methods

Randomized, double-blind, double-dummy trial comparing olsalazine and SASP. Randomization was in blocks of 10 , and the drugs were dispensed by the hospital pharmacy. At entry, 3, and 6 months, a history, clinical exam, sigmoidoscopy, and rectal biopsy were performed
Out-patients, aged 18 to 75 years, with ulcerative colitis in remission (without a relapse for previous 6 months) taking an average dose of $2 \mathrm{~g}$ /day SASP, were recruited over an 18 month period $(\mathrm{N}=164)$

SASP, $2 \mathrm{~g}$ /day, plus olsalazine-matched placebo $(\mathrm{n}=82)$ or olsalazine, $1 \mathrm{~g} /$ day, plus SASP-matched placebo $(n=82)$ for 6 months
Interventions

Outcomes
Relapse was defined as increased stool frequency with or without blood or mucus and with evidence of inflammation on sigmoidoscopy. Withdrawals and the occurrence of side-effects were also reported

Notes

\section{Risk of bias}

\begin{tabular}{lll}
\hline Bias & Authors' judgement & Support for judgement \\
\hline $\begin{array}{l}\text { Random sequence genera- } \\
\text { tion (selection bias) }\end{array}$ & Unclear risk & Not described \\
\hline $\begin{array}{l}\text { Allocation concealment } \\
\text { (selection bias) }\end{array}$ & Low risk & Adequate \\
\hline $\begin{array}{l}\text { Blinding (performance } \\
\text { bias and detection bias) } \\
\text { All outcomes }\end{array}$ & Low risk & Double-blind, double-dummy \\
\hline $\begin{array}{l}\text { Incomplete outcome data } \\
\text { (attrition bias) } \\
\text { All outcomes }\end{array}$ & Low risk & \\
\hline
\end{tabular}

Selective reporting (re- Low risk Expected outcomes were reported
porting bias)

Other bias Low risk The study appears to be free of other sources of bias

Ito 2010

\begin{tabular}{ll}
\hline Methods & Multicenter, randomized, double-blind, double-dummy, non-inferiority trial \\
\hline Participants & $\begin{array}{l}\text { Adult patients (aged } \geq 16 \text { to }<65 \text { years) with quiescent (UC-DAl of } 2 \text { or less and bloody stool score of } 0) \\
\text { ulcerative colitis }(\mathrm{N}=131)\end{array}$ \\
\hline Interventions & Pentasa $2.25 \mathrm{~g} /$ day $(\mathrm{n}=66)$ or Asacol $2.4 \mathrm{~g} / \mathrm{day}(\mathrm{n}=65)$ for 48 weeks \\
\hline Outcomes & $\begin{array}{l}\text { Primary outcome: the proportion of patients without bloody stools. Secondary outcomes were time to } \\
\text { bloody stools, proportion of patients without relapse, time to relapse, decrease in UC-DAl and adverse } \\
\text { events. Relapse was defined as a bloody stool score of } 1 \text { or more and UC-DAl of } 3 \text { or more }\end{array}$
\end{tabular}

\section{Risk of bias}


Ito 2010 (Continued)

\begin{tabular}{|c|c|c|}
\hline Bias & Authors' judgement & Support for judgement \\
\hline $\begin{array}{l}\text { Random sequence genera- } \\
\text { tion (selection bias) }\end{array}$ & Low risk & $\begin{array}{l}\text { Computer generated. Treatment assignment was balanced using a biased-coin } \\
\text { minimization algorithm }\end{array}$ \\
\hline $\begin{array}{l}\text { Allocation concealment } \\
\text { (selection bias) }\end{array}$ & Low risk & $\begin{array}{l}\text { Centralized randomization: A person independent from the study was in } \\
\text { charge of the random allocation. The randomization code was sealed and } \\
\text { stored until the blind was removed }\end{array}$ \\
\hline $\begin{array}{l}\text { Blinding (performance } \\
\text { bias and detection bias) } \\
\text { All outcomes }\end{array}$ & Low risk & Double-blind, double-dummy \\
\hline $\begin{array}{l}\text { Incomplete outcome data } \\
\text { (attrition bias) } \\
\text { All outcomes }\end{array}$ & Low risk & $\begin{array}{l}\text { Drop-outs balanced across intervention groups with similar reasons for with- } \\
\text { drawal }\end{array}$ \\
\hline $\begin{array}{l}\text { Selective reporting (re- } \\
\text { porting bias) }\end{array}$ & Low risk & Expected outcomes were reported \\
\hline Other bias & Low risk & The study appears to be free of other sources of bias \\
\hline
\end{tabular}

Kamm 2008

\begin{tabular}{ll}
\hline Methods & Multicenter, randomized, open-label trial \\
\hline Participants & $\begin{array}{l}\text { Adult patients were entered following induction of remission after an acute flare of mild to moderate } \\
\text { ulcerative colitis }(\mathrm{N}=451 \text { ) in clinical and endoscopic remission (modified UC-DAl score of } \leq 1 \text {, with rec- } \\
\text { tal bleeding and stool frequency scores of } 0 \text {, a combined PGA and sigmoidoscopy score of } \leq 1 \text {, no mu- } \\
\text { cosal friability and } \mathrm{a} \geq 1 \text { point reduction from baseline in sigmoidoscopy score) }\end{array}$ \\
\hline
\end{tabular}

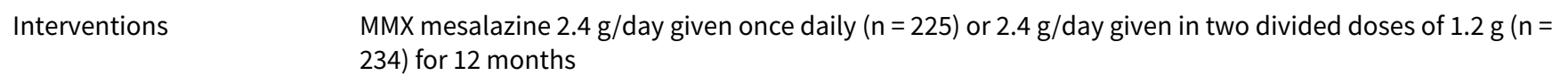
Outcomes
Primary outcome: safety and tolerability of the two dosage regimens over 12 months. Secondary out- comes: proportion of patients in remission at 12 months, changes from baseline in components of the modified UC-DAI, and adherence

Notes Compliance with study medication was calculated by pill count at study visits

\begin{tabular}{|c|c|c|}
\hline \multicolumn{3}{|l|}{ Risk of bias } \\
\hline Bias & Authors' judgement & Support for judgement \\
\hline $\begin{array}{l}\text { Random sequence genera- } \\
\text { tion (selection bias) }\end{array}$ & Unclear risk & Not described \\
\hline $\begin{array}{l}\text { Allocation concealment } \\
\text { (selection bias) }\end{array}$ & Low risk & $\begin{array}{l}\text { Centralized randomization:Patients entering this } 12 \text {-month maintenance } \\
\text { study were randomized via an interactive voice recognition system }\end{array}$ \\
\hline $\begin{array}{l}\text { Blinding (performance } \\
\text { bias and detection bias) } \\
\text { All outcomes }\end{array}$ & High risk & Open-label \\
\hline $\begin{array}{l}\text { Incomplete outcome data } \\
\text { (attrition bias) }\end{array}$ & Low risk & $\begin{array}{l}\text { Drop-outs balanced across intervention groups with similar reasons for with- } \\
\text { drawal }\end{array}$ \\
\hline
\end{tabular}


Kamm 2008 (Continued)

All outcomes

\begin{tabular}{lll}
\hline $\begin{array}{l}\text { Selective reporting (re- } \\
\text { porting bias) }\end{array}$ & Low risk & All expected outcomes reported \\
\hline Other bias & Low risk & The study appears to be free of other sources of bias \\
\hline
\end{tabular}

Kane 2003a

\begin{tabular}{ll}
\hline Methods & Single-center, investigator-blinded, randomized trial \\
\hline Participants & $\begin{array}{l}\text { Adult patients with ulcerative colitis in remission (defined as absence of blood in stools, urgency or } \\
\text { cramping) for at least } 4 \text { months prior to entry }(\mathrm{N}=22)\end{array}$ \\
\hline Interventions & Mesalamine (Asacol) dosed once daily $(\mathrm{n}=12)$ or twice or three times daily $(\mathrm{n}=10)$ for 6 months \\
\hline Outcomes & $\begin{array}{l}\text { The primary outcome was the presence of absence of disease activity at the end of } 6 \text { months treat- } \\
\text { ment. Relapse was defined as a HBI }>3 \text {. Secondary outcomes: adherence and patient satisfaction with } \\
\text { treatment }\end{array}$ \\
\hline Notes & $\begin{array}{l}\text { The mean dose of Asacol in the once daily group was } 2.5 \mathrm{~g} / \text { day. The mean dose of Asacol in the conven- } \\
\text { tionally dosed group was } 2.7 \mathrm{~g} / \text { day. Adherence was calculated using pharmacy data }\end{array}$ \\
\hline
\end{tabular}

\section{Risk of bias}

\begin{tabular}{lll}
\hline Bias & Authors' judgement & Support for judgement \\
\hline $\begin{array}{l}\text { Random sequence genera- } \\
\text { tion (selection bias) }\end{array}$ & Low risk & Random-numbers table \\
\hline $\begin{array}{l}\text { Allocation concealment } \\
\text { (selection bias) }\end{array}$ & Low risk & Opaque sealed envelopes \\
\hline $\begin{array}{l}\text { Blinding (performance } \\
\text { bias and detection bias) }\end{array}$ & High risk & Investigator-blinded \\
\hline $\begin{array}{l}\text { Incomplete outcome data } \\
\text { (attrition bias) } \\
\text { All outcomes }\end{array}$ & Low risk & $\begin{array}{l}\text { Drop-outs balanced across intervention groups with similar reasons for with- } \\
\text { drawal }\end{array}$ \\
\hline $\begin{array}{l}\text { Selective reporting (re- } \\
\text { porting bias) }\end{array}$ & Low risk & All expected outcomes reported \\
\hline \begin{tabular}{l} 
Other bias \\
\hline
\end{tabular} & Unclear risk & The study appears to be free of other sources of bias \\
\hline
\end{tabular}

\section{Kane 2008a}

\begin{tabular}{ll}
\hline Methods & Two center, investigator-blinded, randomized trial \\
\hline Participants & $\begin{array}{l}\text { Adult patients with ulcerative colitis in remission (defined as absence of blood in stools, urgency or } \\
\text { cramping) for at least } 4 \text { months prior to entry }(\mathrm{N}=20)\end{array}$ \\
\hline
\end{tabular}


Kane 2008a (Continued)

Interventions $\quad$ Mesalamine (Asacol) dosed once daily $(n=12)$ or twice or three times daily $(n=8)$ for 12 months

Outcomes The primary outcome was the percentage of patients with quiescent disease at 12 months. Remission was defined as a modified UC-DAI $\leq 3$. Relapse was defined as a UC-DAI > 3. Secondary outcomes: adherence and adverse events

Notes Adherence was calculated using pharmacy data

\section{Risk of bias}

\begin{tabular}{lll}
\hline Bias & Authors' judgement & Support for judgement \\
\hline $\begin{array}{l}\text { Random sequence genera- } \\
\text { tion (selection bias) }\end{array}$ & Low risk & Computer-generated \\
\hline $\begin{array}{l}\text { Allocation concealment } \\
\text { (selection bias) }\end{array}$ & Low risk & Opaque sealed envelopes \\
\hline $\begin{array}{l}\text { Blinding (performance } \\
\text { bias and detection bias) } \\
\text { All outcomes }\end{array}$ & High risk & $\begin{array}{l}\text { Investigator-blinded, patient assessed by blinded physician at } 6 \text { and } 12 \text { month } \\
\text { assessment }\end{array}$ \\
\hline $\begin{array}{l}\text { Incomplete outcome data } \\
\text { (attrition bias) } \\
\text { All outcomes }\end{array}$ & Low risk & One patient in the once daily mesalamine group died \\
\hline $\begin{array}{l}\text { Selective reporting (re- } \\
\text { porting bias) }\end{array}$ & Low risk & All expected outcomes reported \\
\hline \begin{tabular}{l} 
Other bias \\
\hline
\end{tabular} & Low risk & The study appears to be free of other sources of bias \\
\hline
\end{tabular}

Kiilerich 1992

$\begin{array}{ll}\text { Methods } & \text { Multicenter, randomized, double-blind, double-dummy comparison of olsalazine and SASP. Random- } \\ \text { ization scheme was computer-generated, stratified for each center and performed in blocks of } 4 \text { con- } \\ \text { secutive patients within each center. Clinical exam, sigmoidoscopy, and blood tests were performed at } \\ \text { entry and after } 6 \text { and } 12 \text { months (or upon relapse) }\end{array}$
\begin{tabular}{ll}
\hline Participants & $\begin{array}{l}\text { Outpatients, aged } 18 \text { to } 80 \text { years, with ulcerative colitis in remission, but who had at least } 2 \text { attacks of } \\
\text { ulcerative colitis, were recruited from March } 1988 \text { to March } 1989(\mathrm{~N}=226)\end{array}$
\end{tabular}

Interventions

Olsalazine, $1 \mathrm{~g} /$ day $(\mathrm{n}=114)$, or SASP, $2 \mathrm{~g} /$ day $(\mathrm{n}=112)$, in a double-dummy method for 12 months. Patients were instructed to take medications with meals. Patients were questioned upon clinical examination to verify their compliance

Outcomes Relapse was defined as inflammation of the rectal mucosa grade 3-4 on sigmoidoscopy (no distinct vessels in the mucosa, spontaneous bleeding or bleeding by contact with the sigmoidoscope). The total failure rate was also reported

\section{Notes}

\section{Risk of bias}

Bias Authors' judgement Support for judgement


Kiilerich 1992 (Continued)

\begin{tabular}{|c|c|c|}
\hline $\begin{array}{l}\text { Random sequence genera- } \\
\text { tion (selection bias) }\end{array}$ & Low risk & Computer generated \\
\hline $\begin{array}{l}\text { Allocation concealment } \\
\text { (selection bias) }\end{array}$ & Low risk & Adequate \\
\hline $\begin{array}{l}\text { Blinding (performance } \\
\text { bias and detection bias) } \\
\text { All outcomes }\end{array}$ & Low risk & Double-blind, double-dummy \\
\hline $\begin{array}{l}\text { Incomplete outcome data } \\
\text { (attrition bias) } \\
\text { All outcomes }\end{array}$ & Low risk & $\begin{array}{l}\text { Drop-outs balanced across intervention groups with similar reasons for with- } \\
\text { drawal }\end{array}$ \\
\hline $\begin{array}{l}\text { Selective reporting (re- } \\
\text { porting bias) }\end{array}$ & Low risk & Expected outcomes were reported \\
\hline Other bias & Low risk & The study appears to be free of other sources of bias \\
\hline
\end{tabular}

Kruis 1995

\begin{tabular}{ll} 
Methods & $\begin{array}{l}\text { Multicenter, randomized, double-blind comparison of } 3 \text { doses of olsalazine and a standard dose of } \\
\text { SASP. Randomization scheme was computer-generated and performed in blocks of } 8 \text { and stratified for } \\
\text { each center. Clinical assessments were performed at entry, } 2,4 \text { and } 6 \text { months. Endoscopic exam was } \\
\text { performed at entry and after } 6 \text { months (or at relapse) }\end{array}$ \\
\hline Participants & $\begin{array}{l}\text { Patients with proven ulcerative colitis in remission were recruited at } 15 \text { centers in } 3 \text { countries. No con- } \\
\text { comitant medications were permitted ( } \mathrm{N}=148)\end{array}$ \\
\hline Interventions & $\begin{array}{l}\text { Olsalazine } 0.5 \mathrm{~g} / \text { day, } 1.25 \mathrm{~g} / \text { day, } 2.0 \text { g/day, or SASP } 2 \mathrm{~g} / \text { day for } 6 \text { months. Patients were instructed } \\
\text { to take medications with meals. Medications were similar in color, size and weight. Full dosage was } \\
\text { reached after } 5 \text { days. Compliance was monitored }\end{array}$ \\
\hline Outcomes & $\begin{array}{l}\text { Relapse was defined as a change in the endoscopic grading, and corresponding histologic assessment, } \\
\text { to at least moderate activity. Withdrawals were also reported }\end{array}$ \\
\hline Notes &
\end{tabular}

\section{Risk of bias}

\begin{tabular}{|c|c|c|}
\hline Bias & Authors' judgement & Support for judgement \\
\hline $\begin{array}{l}\text { Random sequence genera- } \\
\text { tion (selection bias) }\end{array}$ & Low risk & $\begin{array}{l}\text { Randomization scheme was computer-generated and performed in blocks of } 8 \\
\text { and stratified for each center }\end{array}$ \\
\hline $\begin{array}{l}\text { Allocation concealment } \\
\text { (selection bias) }\end{array}$ & Low risk & Adequate \\
\hline $\begin{array}{l}\text { Blinding (performance } \\
\text { bias and detection bias) } \\
\text { All outcomes }\end{array}$ & Low risk & $\begin{array}{l}\text { The study was double-blind and the medication was similar in colour, size and } \\
\text { weight }\end{array}$ \\
\hline $\begin{array}{l}\text { Incomplete outcome data } \\
\text { (attrition bias) } \\
\text { All outcomes }\end{array}$ & Low risk & $\begin{array}{l}\text { Drop-outs balanced across intervention groups with similar reasons for with- } \\
\text { drawal }\end{array}$ \\
\hline
\end{tabular}


Kruis 1995 (Continued)

Selective reporting (re- Low risk Expected outcomes were reported
porting bias)

Other bias Low risk The study appears to be free of other sources of bias

Kruis 2001

\begin{tabular}{ll}
\hline Methods & Multicenter, randomized, double blind, double dummy, three armed, parallel group trial \\
\hline Participants & Adult patients (aged 18 to 70 years) with ulcerative colitis in remission for less than one year ( $\mathrm{N}=133$ ) \\
\hline Interventions & $\begin{array}{l}\text { Balsalazide } 3 \mathrm{~g} \text { twice daily }(\mathrm{n}=40) \text {, Balsalazide } 1.5 \mathrm{~g} \text { twice daily }(\mathrm{n}=48) \text { or Salofalk } 0.5 \mathrm{~g} \text { three times dai- } \\
\text { ly }(\mathrm{n}=44) \text { for } 26 \text { weeks }\end{array}$ \\
\hline Outcomes & $\begin{array}{l}\text { Primary: proportion of patients in clinical remission at } 26 \text { weeks. Secondary: CAl, endoscopic score, } \\
\text { urine analysis, adverse events. Clinical remission was defined as a CAl }<6 \text {. Endoscopic findings were al- } \\
\text { so classified according to Rachmilewitz and an El score }<4 \text { was considered to indicate remission. Re- } \\
\text { lapse was defined as CAl }>6 \text { and El }>4\end{array}$ \\
\hline Notes & $\begin{array}{l}1 \text { patient randomized to the Balsalazide } 1.5 \mathrm{~g} \text { group did not receive any study medication and was ex- } \\
\text { cluded from the ITT analysis }\end{array}$
\end{tabular}

\section{Risk of bias}

\begin{tabular}{|c|c|c|}
\hline Bias & Authors' judgement & Support for judgement \\
\hline $\begin{array}{l}\text { Random sequence genera- } \\
\text { tion (selection bias) }\end{array}$ & Unclear risk & Not described \\
\hline $\begin{array}{l}\text { Allocation concealment } \\
\text { (selection bias) }\end{array}$ & Unclear risk & Not described \\
\hline $\begin{array}{l}\text { Blinding (performance } \\
\text { bias and detection bias) } \\
\text { All outcomes }\end{array}$ & Low risk & Double-blind, double-dummy, identical placebos \\
\hline $\begin{array}{l}\text { Incomplete outcome data } \\
\text { (attrition bias) } \\
\text { All outcomes }\end{array}$ & Unclear risk & $\begin{array}{l}\text { Patients were more likely to drop-out from the low dose balsalazide group } \\
(26.5 \%) \text { due to lack of efficacy than the high dose balsalazide }(7.5 \%) \text { or the } \\
\text { Salofalk (13.6\%) groups }\end{array}$ \\
\hline $\begin{array}{l}\text { Selective reporting (re- } \\
\text { porting bias) }\end{array}$ & Low risk & Expected outcomes were reported \\
\hline Other bias & Low risk & The study appears to be free of other sources of bias \\
\hline
\end{tabular}

\section{Kruis 2011}

\begin{tabular}{ll}
\hline Methods & Randomized, multicenter, double-blind, double-dummy, parallel group, phase III trial \\
\hline Participants & $\begin{array}{l}\text { Adult patients (aged } 18 \text { to } 75 \text { years) with endoscopically and histologically confirmed ulcerative colitis } \\
(\mathrm{N}=648) \text { in remission }(\mathrm{CAl} \leq 4 \text { and } \mathrm{El} \leq 3)\end{array}$ \\
\hline
\end{tabular}


Kruis 2011 (Continued)

Interventions

Mesalazine (Salofalk granules) $3.0 \mathrm{~g} /$ day dosed once daily $(n=217), 1.5 \mathrm{~g} /$ day dosed once daily $(n=212)$ or $0.5 \mathrm{~g}$ dosed three times daily $(1.5 \mathrm{~g} /$ day $\mathrm{n}=218)$ for one year

Outcomes

The primary outcome was clinical remission at the final visit (relapse was defined as CAI > 4 and an increase of $\geq 3$ from baseline. Secondary outcomes included: clinical remission at month 12 in patients with mucosal inflammation at baseline (EI > 1), endoscopic remission at month 12, change from baseline to month 12 in number of stools and number of bloody stools per week, adherence and adverse events

Notes One patient from the $3.0 \mathrm{~g} /$ day OD group was excluded from the ITT analysis for not receiving any study medication. Adherence was calculated by pill count at study visits and by patient diary

\section{Risk of bias}

\begin{tabular}{|c|c|c|}
\hline Bias & Authors' judgement & Support for judgement \\
\hline $\begin{array}{l}\text { Random sequence genera- } \\
\text { tion (selection bias) }\end{array}$ & Low risk & Computer-generated randomisation list \\
\hline $\begin{array}{l}\text { Allocation concealment } \\
\text { (selection bias) }\end{array}$ & Low risk & $\begin{array}{l}\text { Randomisation was performed centrally in blocks of three by means of a com- } \\
\text { puter-generated randomisation list }\end{array}$ \\
\hline $\begin{array}{l}\text { Blinding (performance } \\
\text { bias and detection bias) } \\
\text { All outcomes }\end{array}$ & Low risk & Double-blind, double-dummy \\
\hline $\begin{array}{l}\text { Incomplete outcome data } \\
\text { (attrition bias) } \\
\text { All outcomes }\end{array}$ & Low risk & $\begin{array}{l}\text { Drop-outs balanced across intervention groups with similar reasons for with- } \\
\text { drawal }\end{array}$ \\
\hline $\begin{array}{l}\text { Selective reporting (re- } \\
\text { porting bias) }\end{array}$ & Low risk & All expected outcomes reported \\
\hline Other bias & Low risk & The study appears to be free of other sources of bias \\
\hline
\end{tabular}

\section{Lichtenstein 2010}

\begin{tabular}{ll}
\hline Methods & Multicenter, randomized, double-blind, placebo-controlled trial \\
\hline Participants & $\begin{array}{l}\text { Adult patients }(\geq 18 \text { years) with ulcerative colitis }(\mathrm{N}=305) \text { in remission (revised Sutherland Disease Ac- } \\
\text { tivity Index (SDAI) rectal bleeding }=0 \text { and mucosal appearance }<2) \text { ). Relapse was defined as SDAI rectal } \\
\text { bleeding score } \geq 1 \text { and a mucosal appearance score } \geq 2 \text {, a UC flare, or initiation of medication to treat a } \\
\text { UC flare }\end{array}$ \\
\hline Interventions & Mesalamine granules (Apriso) $1.5 \mathrm{~g} /$ day dosed once daily $(\mathrm{n}=209)$ or placebo $(\mathrm{n}=96)$ for 6 months \\
\hline Outcomes & $\begin{array}{l}\text { Primary: percentage of patients who were relapse free at } 6 \text { months. Secondary: percentages of patients } \\
\text { with each level of change from baseline in rectal bleeding score, mucosal appearance score, physician's } \\
\text { rating of disease activity and stool frequency on SDAl at months } 1,3 \text {, and } 6 \text { and end of treatment; per- } \\
\text { centage of patients classified as treatment success, relapse-free duration, and adverse events }\end{array}$
\end{tabular}

Notes

\section{Risk of bias}


Lichtenstein 2010 (Continued)

\begin{tabular}{|c|c|c|}
\hline Bias & Authors' judgement & Support for judgement \\
\hline $\begin{array}{l}\text { Random sequence genera- } \\
\text { tion (selection bias) }\end{array}$ & Unclear risk & Not described \\
\hline $\begin{array}{l}\text { Allocation concealment } \\
\text { (selection bias) }\end{array}$ & Unclear risk & Not described \\
\hline $\begin{array}{l}\text { Blinding (performance } \\
\text { bias and detection bias) } \\
\text { All outcomes }\end{array}$ & Low risk & Double-blind, matching placebo \\
\hline $\begin{array}{l}\text { Incomplete outcome data } \\
\text { (attrition bias) } \\
\text { All outcomes }\end{array}$ & Low risk & $\begin{array}{l}\text { Drop-outs balanced across intervention groups with similar reasons for with- } \\
\text { drawal }\end{array}$ \\
\hline $\begin{array}{l}\text { Selective reporting (re- } \\
\text { porting bias) }\end{array}$ & Low risk & All expected outcomes reported \\
\hline Other bias & Low risk & The study appears to be free of other sources of bias \\
\hline
\end{tabular}

Mahmud 2002

\begin{tabular}{ll}
\hline Methods & Single center, randomized, parallel group trial \\
\hline Participants & $\begin{array}{l}\text { Adult patients (aged } \geq 18 \text { to } 70 \text { years) with a confirmed diagnosis of ulcerative colitis in remission ( } \mathrm{N}= \\
40)\end{array}$ \\
\hline Interventions & Asacol $1.2 \mathrm{~g} /$ day $(\mathrm{n}=20)$ or Olsalazine $1 \mathrm{~g} / \mathrm{day}(\mathrm{n}=20)$ for 9 months \\
\hline Outcomes & $\begin{array}{l}\text { Clinical remission, laboratory assessments and adverse events. Remission was defined as HBI }<3 \text { and a } \\
\text { sigmoidoscopy score of } 0 \text { to } 1\end{array}$ \\
\hline Notes & $\begin{array}{l}\text { The primary objective was to evaluate the effects of } 9 \text { months of therapy with Asacol or Olsalazine on } \\
\text { renal function }\end{array}$ \\
\hline
\end{tabular}

\section{Risk of bias}

\begin{tabular}{lll}
\hline Bias & Authors' judgement & Support for judgement \\
\hline $\begin{array}{l}\text { Random sequence genera- } \\
\text { tion (selection bias) }\end{array}$ & Low risk & Computer-generated code \\
\hline $\begin{array}{l}\text { Allocation concealment } \\
\text { (selection bias) }\end{array}$ & Unclear risk & Not described \\
\hline $\begin{array}{l}\text { Blinding (performance } \\
\text { bias and detection bias) } \\
\text { All outcomes }\end{array}$ & High risk & Open study \\
\hline $\begin{array}{l}\text { Incomplete outcome data } \\
\text { (attrition bias) }\end{array}$ & Low risk & \\
All outcomes & & $\begin{array}{l}\text { Drop-outs balanced across intervention groups with similar reasons for with- } \\
\text { drawal }\end{array}$
\end{tabular}


Mahmud 2002 (Continued)

Selective reporting (re- Low risk $\quad$ Expected outcomes were reported
porting bias)

Other bias Low risk The study appears to be free of other sources of bias

\section{McIntyre 1988}

$\begin{array}{ll}\text { Methods } & \text { Randomized, double-blind comparison of balsalazide and SASP. Extent of disease was initially classi- } \\ & \text { fied by most recent barium enema, sigmoidoscopy and rectal biopsy as: extensive, substantial, left- } \\ & \text { sided, proctosigmoiditis, or proctitis. Evaluation continued throughout study at 4, 8, 16 and 24 weeks } \\ & \text { by clinical exam, sigmoidoscopy, and rectal biopsy (if deterioration occurred) }\end{array}$

\begin{tabular}{ll}
\hline Participants & $\begin{array}{l}\text { Adult patients (aged } 18 \text { to } 79 \text { years) with ulcerative colitis with clinical and sigmoidoscopic (non-friable } \\
\text { mucosa) remission, and who were not currently on maintenance therapy, or who agreed to substitute } \\
\text { trial capsules for maintenance SASP }(\mathrm{N}=79)\end{array}$ \\
\hline Interventions & Balsalazide $(\mathrm{n}=41)$ or SASP, $2 \mathrm{~g} / \mathrm{day}(\mathrm{n}=38)$ in identical $500 \mathrm{mg}$ capsules, for 6 months \\
\hline Outcomes & $\begin{array}{l}\text { Relapse was defined as the recurrence of previous symptoms. Patients completing } 6 \text { months without } \\
\text { recurrence were classified as maintaining remission; the rest were considered to be treatment failures. } \\
\text { Exclusions, withdrawals, and the occurrence of adverse side-effects were also recorded }\end{array}$
\end{tabular}

\section{Notes}

\section{Risk of bias}

\begin{tabular}{|c|c|c|}
\hline Bias & Authors' judgement & Support for judgement \\
\hline $\begin{array}{l}\text { Random sequence genera- } \\
\text { tion (selection bias) }\end{array}$ & Unclear risk & Not described \\
\hline $\begin{array}{l}\text { Allocation concealment } \\
\text { (selection bias) }\end{array}$ & Low risk & Adequate \\
\hline $\begin{array}{l}\text { Blinding (performance } \\
\text { bias and detection bias) } \\
\text { All outcomes }\end{array}$ & Low risk & Double-blind: identical capsules \\
\hline $\begin{array}{l}\text { Incomplete outcome data } \\
\text { (attrition bias) } \\
\text { All outcomes }\end{array}$ & Low risk & $\begin{array}{l}\text { Drop-outs balanced across intervention groups with similar reasons for with- } \\
\text { drawal }\end{array}$ \\
\hline $\begin{array}{l}\text { Selective reporting (re- } \\
\text { porting bias) }\end{array}$ & Low risk & Expected outcomes reported \\
\hline Other bias & Low risk & The study appears to be free of other sources of bias \\
\hline
\end{tabular}

Miner 1995

$\begin{array}{ll}\text { Methods } & \text { Multicenter, randomized, double-blind, placebo-controlled and parallel design trial. Patients were } \\ \text { stratified according to location of the disease. Clinical assessments were performed at entry, } 1,2,3,6, \\ 9 \text { and } 12 \text { months. At entry and final visit, sigmoidoscopy and histological assessments were performed. } \\ \text { Patients were also required to keep daily diaries }\end{array}$


Miner 1995 (Continued)

Participants

Interventions

Patients, 18 years or older, previously diagnosed with ulcerative colitis and in remission. Use of immunosuppressives or steroids required 90-day and 60-day wash-out periods, respectively $(N=205)$

Controlled-release mesalamine, in $250 \mathrm{mg}$ capsules (Pentasa) $4 \mathrm{~g} /$ day $(\mathrm{n}=103$ ) or identical-appearing placebo $(n=102)$ for 48 weeks, distributed in blister packaging. Compliance was verified by pill count

\section{Outcomes}

Recurrence of disease was defined as one of the following: 1) a sigmoidoscopic index of greater or equal to 5 , and 5 or more trips to the toilet per day or rectal bleeding for 3 of 7 continuous days; 2 ) sigmoidoscopic index of 5 or more, with missing data for toilet visits or rectal bleeding; 3 ) missing data for final sigmoidoscopic index and early termination due to insufficient therapeutic effect
Notes
Failure rate was calculated as "1 - reported remission rate"

\section{Risk of bias}

\begin{tabular}{|c|c|c|}
\hline Bias & Authors' judgement & Support for judgement \\
\hline $\begin{array}{l}\text { Random sequence genera- } \\
\text { tion (selection bias) }\end{array}$ & Unclear risk & Not described \\
\hline $\begin{array}{l}\text { Allocation concealment } \\
\text { (selection bias) }\end{array}$ & Low risk & Adequate \\
\hline $\begin{array}{l}\text { Blinding (performance } \\
\text { bias and detection bias) } \\
\text { All outcomes }\end{array}$ & Low risk & Identical placebo \\
\hline $\begin{array}{l}\text { Incomplete outcome data } \\
\text { (attrition bias) } \\
\text { All outcomes }\end{array}$ & Unclear risk & $\begin{array}{l}34 \text { patients in the placebo dropped out due to adverse reaction compared to } \\
14 \text { in the mesalamine group }\end{array}$ \\
\hline $\begin{array}{l}\text { Selective reporting (re- } \\
\text { porting bias) }\end{array}$ & Low risk & Expected outcomes were reported \\
\hline Other bias & Low risk & The study appears to be free of other sources of bias \\
\hline
\end{tabular}

\section{Mulder 1988}

$\begin{array}{ll}\text { Methods } & \text { Multicenter, randomized, double-blinded, double-dummy comparison of Pentasa and SASP. Evaluation } \\ \text { at entry involved clinical, endoscopic, and histologic examinations. Follow-ups occurred at 3, 6, } 9 \text { and } \\ 12 \text { months after entry }\end{array}$

Participants Male and female outpatients, 18 years or older, with ulcerative colitis in remission for between 1 month and 5 years, who had not taken steroids or azathioprine during the month before entry $(\mathrm{N}=78)$
Interventions Six tablets $(1.5 \mathrm{~g})$ of Pentasa $(5-\mathrm{ASA})$ plus 6 SASP-matched placebo tablets $(\mathrm{n}=42)$ or 6 Pen- tasa-matched placebo tablets plus 6 tablets $(3 \mathrm{~g})$ of SASP daily $(n=36)$ for 12 months. Patients were to take medication in 3 doses before or after main meals. Placebo tablets were matched in appearance, weight and taste

Outcomes

If the data obtained at each examination were assessed as 'normal' or 'in remission', the patient was considered to have remained in remission. If, at any time, the patient had not been considered 'normal' or 'in remission', then the patient was considered to have relapsed. Outcomes were reported in terms of remission rates. Side effects and withdrawals were also recorded 
Mulder 1988 (Continued)

Notes

\section{Risk of bias}

\begin{tabular}{lll}
\hline Bias & Authors' judgement & Support for judgement \\
\hline $\begin{array}{l}\text { Random sequence genera- } \\
\text { tion (selection bias) }\end{array}$ & Unclear risk & Not described \\
\hline $\begin{array}{l}\text { Allocation concealment } \\
\text { (selection bias) }\end{array}$ & Low risk & Adequate \\
\hline $\begin{array}{l}\text { Blinding (performance } \\
\text { bias and detection bias) } \\
\text { All outcomes }\end{array}$ & Low risk & $\begin{array}{l}\text { Double-blind, double-dummy: placebo tablets were identical in appearance, } \\
\text { weight and taste }\end{array}$ \\
\hline $\begin{array}{l}\text { Incomplete outcome data } \\
\text { (attrition bias) } \\
\text { All outcomes }\end{array}$ & Low risk & 3 patients dropped out (2 from Pentasa group and 1 from SASP) \\
\hline $\begin{array}{l}\text { Selective reporting (re- } \\
\text { porting bias) }\end{array}$ & Low risk & Expected outcomes were reported \\
\hline \begin{tabular}{l} 
Other bias \\
\hline
\end{tabular} & Low risk & The study appears to be free of other sources of bias \\
\hline
\end{tabular}

\section{Nilsson 1995}

$\begin{array}{ll}\text { Methods } & \text { Multicenter, randomized, double-blind, double-dummy comparison of SASP and olsalazine. Clinical as- } \\ \text { sessments were performed after every } 3 \text { months or more frequently if relapse was suspected. Rigid sig- } \\ \text { moidoscopy was performed at entry and after } 6 \text { and } 18 \text { months }\end{array}$

Participants Patients with ulcerative colitis in remission, with at least 2 episodes of active disease during the last 5 years. No other concomitant medications were permitted $(\mathrm{N}=322)$

Interventions

Olsalazine, $1 \mathrm{~g} /$ day, with SASP-matched placebo $(\mathrm{n}=161)$ or active SASP, $2 \mathrm{~g} /$ day, with ol-

salazine-matched placebo $(n=161)$ for either $6,9,12,15$ or 18 months. Patients were instructed to take medication with meals. Full treatment regimen was reached after 7 days. Compliance was verified by pill counts

Relapse was defined as macroscopic changes in the rectum of grade 3 or 4 on a 4-point scale. Other
measures of efficacy were changes in number of stools per day, blood in stools, and consistency of
stools. The failure rates were reported on an intention-to-treat basis

\section{Notes}

\section{Risk of bias}

\begin{tabular}{lll}
\hline Bias & Authors' judgement & Support for judgement \\
\hline $\begin{array}{l}\text { Random sequence genera- } \\
\text { tion (selection bias) }\end{array}$ & Unclear risk & Not described \\
\hline $\begin{array}{l}\text { Allocation concealment } \\
\text { (selection bias) }\end{array}$ & Low risk & A - Adequate \\
\hline
\end{tabular}


Nilsson 1995 (Continued)
Blinding (performance
Low risk
Double-blind, double-dummy (matched placebos)

bias and detection bias)

All outcomes

\begin{tabular}{lll}
\hline $\begin{array}{l}\text { Incomplete outcome data } \\
\text { (attrition bias) } \\
\text { All outcomes }\end{array}$ & Low risk & $\begin{array}{l}\text { Drop-outs balanced across intervention groups with similar reasons for with- } \\
\text { drawal }\end{array}$ \\
\hline $\begin{array}{l}\text { Selective reporting (re- } \\
\text { porting bias) }\end{array}$ & Low risk & Expected outcomes were reported \\
\hline Other bias & Low risk & The study appears to be free of other sources of bias \\
\hline
\end{tabular}

Paoluzi 2005

\begin{tabular}{ll}
\hline Methods & Single center, randomized, investigator-blind trial \\
\hline Participants & $\begin{array}{l}\text { Adult patients }(>18 \text { years) with confirmed ulcerative colitis in clinical, endoscopic and histological re- } \\
\text { mission }(\mathrm{N}=156)\end{array}$ \\
\hline Interventions & Asacol $2.4 \mathrm{~g} /$ day $(\mathrm{n}=80)$ or $1.2 \mathrm{~g} /$ day $(\mathrm{n}=76)$ for 12 months \\
\hline Outcomes & Primary: maintenance of remission (Truelove and Witts). Secondary: time to relapse, adverse events \\
\hline Notes & \\
\hline
\end{tabular}

\section{Risk of bias}

\begin{tabular}{lll}
\hline Bias & Authors' judgement & Support for judgement \\
\hline $\begin{array}{l}\text { Random sequence genera- } \\
\text { tion (selection bias) }\end{array}$ & Unclear risk & Not described \\
\hline $\begin{array}{l}\text { Allocation concealment } \\
\text { (selection bias) }\end{array}$ & Unclear risk & Not described \\
\hline $\begin{array}{l}\text { Blinding (performance } \\
\text { bias and detection bias) }\end{array}$ & Low risk & Investigator-blinded \\
\hline $\begin{array}{l}\text { Ill outcomes } \\
\text { (attrition bias) } \\
\text { All outcomes }\end{array}$ & Low risk & $\begin{array}{l}\text { Drop-outs balanced across intervention groups with similar reasons for with- } \\
\text { drawal }\end{array}$ \\
\hline $\begin{array}{l}\text { Selective reporting (re- } \\
\text { porting bias) }\end{array}$ & Low risk & Expected outcomes were reported \\
\hline \begin{tabular}{l} 
Other bias \\
\hline
\end{tabular} & Low risk & The study appears to be free of other sources of bias \\
\hline
\end{tabular}

\section{Pica 2012}

Methods Randomised open label trial


Pica 2012 (Continued)

\begin{tabular}{ll} 
Participants & Patients with ulcerative colitis in remission $(\mathrm{N}=112)$ \\
\hline Interventions & Asacol $4.8 \mathrm{~g} /$ day $(\mathrm{n}=56)$ or $2.4 \mathrm{~g} /$ day $(\mathrm{n}=56)$ for 12 months \\
\hline Outcomes & Remission at 12 months \\
\hline Notes & Abstract publication
\end{tabular}

\section{Risk of bias}

\begin{tabular}{lll}
\hline Bias & Authors' judgement & Support for judgement \\
\hline $\begin{array}{l}\text { Random sequence genera- } \\
\text { tion (selection bias) }\end{array}$ & Unclear risk & Not described \\
\hline $\begin{array}{l}\text { Allocation concealment } \\
\text { (selection bias) }\end{array}$ & Unclear risk & Not described \\
\hline $\begin{array}{l}\text { Blinding (performance } \\
\text { bias and detection bias) } \\
\text { All outcomes }\end{array}$ & High risk & Open label \\
\hline $\begin{array}{l}\text { Incomplete outcome data } \\
\text { (attrition bias) } \\
\text { All outcomes }\end{array}$ & Unclear risk & Drop-outs and reasons for withdrawal were not described \\
\hline $\begin{array}{l}\text { Selective reporting (re- } \\
\text { porting bias) }\end{array}$ & Unclear risk & Secondary outcomes were not described \\
\hline \begin{tabular}{l} 
Other bias \\
\hline
\end{tabular} & Unclear risk & Abstract publication \\
\hline
\end{tabular}

\section{Prantera 2009}

Methods Double-blind, double-dummy, parallel-group, randomized trial evaluating the efficacy and safety of MMX mesalazine dosed once daily ( $2.4 \mathrm{~g} /$ day) compared with Asacol ( $1.2 \mathrm{~g}$ twice daily) for the maintenance of clinical remission in patients with quiescent ulcerative colitis

Adult patients (aged 18 to 75 years) in remission (modified UC-DAI score of $\leq 1$ supported by a rectal sig-
moidoscopy in the preceding 3 months or colonoscopy in the preceding 6 months) for $\geq 1$ month prior
to entry and had experienced at least one clinical or endoscopic relapse within the previous 12 months
were recruited from centers in Italy, Poland and the Ukraine $(\mathrm{N}=331)$

\begin{tabular}{ll}
\hline Interventions & $\begin{array}{l}\text { MMX mesalazine } 2.4 \mathrm{~g} / \text { day }(\mathrm{n}=162) \text { given once daily or Asacol } 2.4 \mathrm{~g} / \text { day }(\mathrm{n}=169) \text { given in two divided } \\
\text { doses of } 1.2 \mathrm{~g} \text { for } 12 \text { months }\end{array}$
\end{tabular}

The primary outcomes were the proportion of patients in clinical remission and the proportion of pa-
tients in clinical and endoscopic remission at 12 months. Secondary outcomes included the time to re-
lapse (UC-DAI > 1) and assessment of the safety and tolerability of MMX mesalazine $2.4 \mathrm{~g} /$ day. Patients
were assessed at screening, entry and at 3, 6,9 and 12 months (or early withdrawal)

\begin{tabular}{ll}
\hline Notes & $\begin{array}{l}\text { Adherence was checked by tablet counts at each visit. Adherence was defined as taking } \geq 80 \% \text { of the } \\
\text { study medication }\end{array}$
\end{tabular}

\section{Risk of bias}


Prantera 2009 (Continued)

\begin{tabular}{lll} 
Bias & Authors' judgement & Support for judgement \\
\hline $\begin{array}{l}\text { Random sequence genera- } \\
\text { tion (selection bias) }\end{array}$ & Low risk & Computer generated \\
\hline $\begin{array}{l}\text { Allocation concealment } \\
\text { (selection bias) }\end{array}$ & Low risk & Centralized randomization \\
\hline $\begin{array}{l}\text { Blinding (performance } \\
\text { bias and detection bias) } \\
\text { All outcomes }\end{array}$ & Low risk & Double-blind, double-dummy \\
\hline $\begin{array}{l}\text { Incomplete outcome data } \\
\text { (attrition bias) } \\
\text { All outcomes }\end{array}$ & Low risk & $\begin{array}{l}\text { Drop-outs balanced across intervention groups with similar reasons for with- } \\
\text { drawal }\end{array}$ \\
\hline $\begin{array}{l}\text { Selective reporting (re- } \\
\text { porting bias) }\end{array}$ & Low risk & All expected outcomes reported \\
\hline \begin{tabular}{l} 
Other bias \\
\hline
\end{tabular} & Low risk & The study appears to be free of other sources of bias \\
\hline
\end{tabular}

\section{Rijk 1992}

$\begin{array}{ll}\text { Methods } & \text { Multicenter, randomized, double-blind comparison of SASP and olsalazine. Randomization used a } \\ \text { standard variance allocation method to ensure equal distribution of prognostic factors among both } \\ \text { treatments. In addition to patient diaries, clinical exam, blood counts and urinalysis were performed af- } \\ \text { ter } 4,12,24,36 \text { and } 48 \text { weeks. Sigmoidoscopy and biopsy was performed at entry and } 48 \text { weeks to veri- } \\ \text { fy remission }\end{array}$

Patients with ulcerative colitis in remission for no longer than 2 years, and with active colitis in the past
(proven by endoscopy/biopsies) were recruited between Dec. 1985 and Jan. 1989. Remission was de-
fined as the absence of clinical signs of inflammation ( 3 or fewer stools/day) and a normal mucosa on
sigmoidoscopic assessment. Some patients had participated in a trial comparing olsalazine and SASP
in active ulcerative colitis and had achieved remission after 6 to 12 weeks of treatment $(\mathrm{N}=46)$

\begin{tabular}{ll}
\hline Interventions & $\begin{array}{l}\text { SASP, } 4 \mathrm{~g} / \text { day }(\mathrm{n}=23) \text {, or olsalazine, } 2 \mathrm{~g} / \mathrm{day}(\mathrm{n}=23), \text { for } 48 \text { weeks, full dosage being reached by the } 5 \text { th } \\
\text { day. Dose reduction to } 3 \mathrm{~g} \text { and } 1.5 \mathrm{~g} \text {, respectively, was allowed in case of adverse effects. Drugs were } \\
\text { given in physically indistinguishable capsules in sealed plastic containers }\end{array}$ \\
\hline Outcomes & $\begin{array}{l}\text { Relapse was defined as a recurrence of symptoms (blood in stools, with or without diarrhea) and signs } \\
\text { of inflammation at endoscopy, even without the presence of patient complaints. Adverse effects and } \\
\text { withdrawals were also reported }\end{array}$
\end{tabular}

\section{Notes}

\section{Risk of bias}

\begin{tabular}{lll}
\hline Bias & Authors' judgement & Support for judgement \\
\hline $\begin{array}{l}\text { Random sequence genera- } \\
\text { tion (selection bias) }\end{array}$ & Unclear risk & Not described \\
\hline $\begin{array}{l}\text { Allocation concealment } \\
\text { (selection bias) }\end{array}$ & Low risk & Centralized randomization \\
\hline
\end{tabular}


Rijk 1992 (Continued)

$\begin{array}{ll}\begin{array}{l}\text { Blinding (performance } \\ \text { bias and detection bias) }\end{array} \quad \text { Low risk } & \begin{array}{l}\text { Double-blind: SASP and olsalazine were given in externally indistinguishable } \\ \text { capsules }\end{array}\end{array}$
All outcomes

\begin{tabular}{|c|c|c|}
\hline $\begin{array}{l}\text { Incomplete outcome data } \\
\text { (attrition bias) }\end{array}$ & Unclear risk & $\begin{array}{l}8 \text { patients dropped out from the olsalazine group ( } 3 \text { due to diarrhea) com- } \\
\text { pared to } 4 \text { in the SASP group }\end{array}$ \\
\hline
\end{tabular}

All outcomes pared to 4 in the SASP group

Selective reporting (re- Low risk $\quad$ Expected outcomes were reported
porting bias)

Other bias Low risk The study appears to be free of other sources of bias

Riley 1988

\begin{tabular}{ll}
\hline Methods & Randomized, double-blind, double-dummy, parallel group design comparing mesalazine (Asacol) and \\
SASP. Randomization was governed by a centrally-held pharmacy code and medication was pre-pack- \\
aged and equally and randomly allocated to each center. In addition to daily diary records, patients \\
were evaluated at entry and at 4, 12, 24, 36 and 48 weeks for clinical exam, urine specimen, blood tests. \\
At entry and at completion (or relapse), sigmoidoscopy and biopsy were performed
\end{tabular}

\begin{tabular}{ll}
\hline Participants & $\begin{array}{l}\text { Adult outpatients with chronic ulcerative colitis in clinical remission for a minimum of } 1 \text { month before } \\
\text { entry, recruited from three hospitals in close geographic proximity. All had appearance of normal mu- } \\
\text { cosa or only erythema upon entry. All had previously taken SASP maintenance therapy }(\mathrm{N}=100)\end{array}$
\end{tabular}

Interventions

SASP, $\min 2 \mathrm{~g} /$ day, plus mesalazine-matched placebo $(n=50)$ or mesalazine, $\min .0 .8 \mathrm{~g} /$ day plus SASPmatched placebo $(n=50)$ for 48 weeks. Compliance was verified by pill counts

\section{Outcomes}

Relapse was indicated by symptomatic disease recurrence. Confirmation of worsened appearance of rectal mucosa was verified by sigmoidoscopy. Withdrawals and occurrence of side-effects were also reported

\begin{tabular}{|c|c|c|}
\hline Notes & & \\
\hline \multicolumn{3}{|l|}{ Risk of bias } \\
\hline Bias & Authors' judgement & Support for judgement \\
\hline $\begin{array}{l}\text { Random sequence genera- } \\
\text { tion (selection bias) }\end{array}$ & Unclear risk & Not described \\
\hline $\begin{array}{l}\text { Allocation concealment } \\
\text { (selection bias) }\end{array}$ & Low risk & Randomization was governed by a centrally-held pharmacy code \\
\hline $\begin{array}{l}\text { Blinding (performance } \\
\text { bias and detection bias) } \\
\text { All outcomes }\end{array}$ & Low risk & Double-blind, double-dummy (matched placebo) \\
\hline $\begin{array}{l}\text { Incomplete outcome data } \\
\text { (attrition bias) } \\
\text { All outcomes }\end{array}$ & Low risk & $\begin{array}{l}12 \% \text { of the SASP group withdrew }(n=6) \text { compared to } 4 \% \text { of the } 5 \text {-ASA group ( } n \\
=2 \text { ) }\end{array}$ \\
\hline $\begin{array}{l}\text { Selective reporting (re- } \\
\text { porting bias) }\end{array}$ & Low risk & Expected outcomes were reported \\
\hline
\end{tabular}


Riley 1988 (Continued)
Other bias
Low risk
The study appears to be free of other sources of bias

\section{Rutgeerts 1989}

Methods Randomized, double-blind, double-dummy comparison of Claversal (5-ASA) and SASP. Clinical exam, including blood work and urinalysis was performed at entry, 1, 2, 3, 6, 9, and 12 months (or earlier for relapse). Colonoscopy was performed if symptoms recurred

\begin{tabular}{|c|c|}
\hline Participants & $\begin{array}{l}\text { Adult patients with inactive ulcerative colitis controlled (score of } 4 \text { or lower on a standard index) for } 1 \\
\text { month pre-trial on a stable sulfasalazine dose of } 1.5 \text { to } 2 \mathrm{~g} / \mathrm{day}(\mathrm{N}=334)\end{array}$ \\
\hline Interventions & $\begin{array}{l}\text { SASP, } 1.5 \text { to } 2 \mathrm{~g} / \text { day }(n=167) \text {, or coated } 5 \text {-ASA (Claversal), } 0.75 \mathrm{~g} / \text { day }(n=167) \text {, dispensed according to } \\
\text { a double-dummy protocol for } 12 \text { months }\end{array}$ \\
\hline Outcomes & Relapse was defined as a clinical index of 6 or greater. Withdrawals and adverse events were reported \\
\hline
\end{tabular}

\section{Risk of bias}

\begin{tabular}{lll}
\hline Bias & Authors' judgement & Support for judgement \\
\hline $\begin{array}{l}\text { Random sequence genera- } \\
\text { tion (selection bias) }\end{array}$ & Unclear risk & $\begin{array}{l}\text { Drug supplies were labelled and randomized in blocks according to a predeter- } \\
\text { mined computer-generated list }\end{array}$ \\
\hline $\begin{array}{l}\text { Allocation concealment } \\
\text { (selection bias) }\end{array}$ & Low risk & Adequate \\
\hline $\begin{array}{l}\text { Blinding (performance } \\
\text { bias and detection bias) } \\
\text { All outcomes }\end{array}$ & Low risk & Double-blind, double-dummy \\
\hline
\end{tabular}

\begin{tabular}{lll}
\hline $\begin{array}{l}\text { Incomplete outcome data } \\
\text { (attrition bias) } \\
\text { All outcomes }\end{array}$ & Unclear risk & $\begin{array}{l}60 \text { patients in the 5-ASA did not complete the study compared to 41 SASP pa- } \\
\text { tients. The reasons for withdrawal are not adequately described }\end{array}$ \\
\hline $\begin{array}{l}\text { Selective reporting (re- } \\
\text { porting bias) }\end{array}$ & Low risk & Expected outcomes were reported \\
\hline Other bias & Low risk & The study appears to be free of other sources of bias \\
\hline
\end{tabular}

\section{Sandberg-Gertzen 1986}

\begin{tabular}{ll}
\hline Methods & $\begin{array}{l}\text { Randomized, double-blind, placebo-controlled trial. Patients were evaluated (clinically, sigmoidoscop- } \\
\text { ically, and histologically) upon entry and completion, plus by regular telephone contact }\end{array}$ \\
\hline Participants & $\begin{array}{l}\text { Patients, of any age, with ulcerative colitis who, after } 6 \text { months of ADS (Dipentum) therapy, were in re- } \\
\text { mission }(\mathrm{N}=102)\end{array}$ \\
\hline Interventions & $\begin{array}{l}\text { Azodisal sodium (ADS, Dipentum), } 1 \mathrm{~g} / \text { day }(\mathrm{n}=52) \text {, or identical-appearing placebo ( } 16 \mathrm{mg} \text { riboflavin; } \mathrm{n} \\
=49) \text { for } 6 \text { months. Compliance was tested by urine and serum analyses and pill count }\end{array}$ \\
\hline
\end{tabular}


Sandberg-Gertzen 1986 (Continued)

Outcomes Relapse was defined as the occurrence of diarrhea with macroscopic blood, together with the finding of active inflammation on sigmoidoscopy

Notes

One placebo patient was excluded from the ITT analysis for entry criteria violation

\section{Risk of bias}

\begin{tabular}{lll}
\hline Bias & Authors' judgement & Support for judgement \\
\hline $\begin{array}{l}\text { Random sequence genera- } \\
\text { tion (selection bias) }\end{array}$ & Unclear risk & Not described \\
\hline $\begin{array}{l}\text { Allocation concealment } \\
\text { (selection bias) }\end{array}$ & Low risk & Adequate \\
\hline $\begin{array}{l}\text { Blinding (performance } \\
\text { bias and detection bias) }\end{array}$ & Low risk & Double-blind: identical placebo \\
\hline $\begin{array}{l}\text { All outcomes } \\
\begin{array}{l}\text { Incomplete outcome data } \\
\text { All outcomes }\end{array}\end{array}$ & Unclear risk & No drop-outs were reported \\
\hline $\begin{array}{l}\text { Selective reporting (re- } \\
\text { porting bias) }\end{array}$ & Low risk & Expected outcomes were reported \\
\hline \begin{tabular}{l} 
Other bias \\
\hline
\end{tabular} & Low risk & The study appears to be free of other sources of bias \\
\hline
\end{tabular}

\section{Sandborn 2010}

Methods
and safety of mesalamine (Asacol) 1.6 to $2.4 \mathrm{~g} /$ day administered once daily with mesalamine (Asacol)
1.6 to $2.4 \mathrm{~g} /$ day administered as a divided twice daily dose for the maintenance of clinical remission in
patients with ulcerative colitis who have experienced a mild to moderate disease course

Adult patients (aged $\geq 18$ years) with quiescent ulcerative colitis (Simple Clinical Colitis Activity Index $\leq$
2) of at least 3 months duration on a stable dose of Asacol ranging from 1.6 to $2.4 \mathrm{~g} / \mathrm{day}$ were recruited
from 193 sites in the USA, Puerto Rico and Canada for the study $(\mathrm{n}=1023)$. Patients must have experi-
enced at least one flare of ulcerative colitis within 18 months of entry $(\mathrm{N}=1023)$

\begin{tabular}{ll}
\hline Interventions & $\begin{array}{l}\text { Mesalamine (Asacol) } 1.6 \text { to } 2.4 \mathrm{~g} / \text { day dosed either once daily }(n=512) \text { or twice daily }(n=511) \text { for } 12 \\
\text { months }\end{array}$
\end{tabular}

\begin{tabular}{ll}
\hline Outcomes & Primary outcome was maintenance of remission at 6 months (SSCAI $\geq 5$ defined relapse). Secondary \\
outcomes included: patient defined remission index, adherence (MARS scale), patient satisfaction and \\
preference with dosing regimen, serious adverse events, adverse events leading to withdrawal
\end{tabular}

Notes

\section{Risk of bias}

\begin{tabular}{lll}
\hline Bias & Authors' judgement & Support for judgement \\
\hline $\begin{array}{l}\text { Random sequence genera- } \\
\text { tion (selection bias) }\end{array}$ & Unclear risk & Not described \\
\hline
\end{tabular}


Sandborn 2010 (Continued)

$\begin{array}{ll}\begin{array}{l}\text { Allocation concealment } \\ \text { (selection bias) }\end{array} & \text { Low risk }\end{array}$
(selection bias)

High risk Investigator-blinded, blinded investigator assessed outcome

Blinding (performance

bias and detection bias)

All outcomes

$\begin{array}{ll}\begin{array}{l}\text { Incomplete outcome data } \\ \text { (attrition bias) }\end{array} & \text { Low risk } \\ \text { All outcomes } & \begin{array}{l}\text { Drop-outs balanced across intervention groups with similar reasons for with- } \\ \text { drawal }\end{array}\end{array}$

All outcomes

Selective reporting (re- Low risk All expected outcomes reported
porting bias)

Other bias Low risk The study appears to be free of other sources of bias

Travis 1994

\begin{tabular}{ll}
\hline Methods & Two-center, randomized, parallel group dose-ranging study \\
\hline Participants & $\begin{array}{l}\text { Adult patients with ulcerative colitis in remission }(\mathrm{N}=198) \text { for three or more months. Remission was de- } \\
\text { fined as no clinical symptoms of active disease and no signs of active inflammation on sigmoidoscopy } \\
\text { (grade } 0 \text { or } 1: \text { normal or pink mucosa of quiescent colitis without visible vessels) }\end{array}$
\end{tabular}

\begin{tabular}{ll}
\hline Interventions & Olsalazine at a dose of $0.5 \mathrm{~g} /$ day $(\mathrm{n}=67), 1.0 \mathrm{~g} /$ day $(\mathrm{n}=65)$ or $2.0 \mathrm{~g} /$ day $(\mathrm{n}=62)$ for $12 \mathrm{months}$ \\
\hline Outcomes & $\begin{array}{l}\text { Primary: relapse defined as an increase in bowel frequency with blood or mucus and evidence of active } \\
\text { disease on sigmoidoscopy. Secondary: time in remission from start of treatment, laboratory measure- } \\
\text { ments, adverse events }\end{array}$ \\
\hline Notes & 4 patients did not receive any study drugs and were excluded from the ITT analysis
\end{tabular}

\section{Risk of bias}

\begin{tabular}{lll}
\hline Bias & Authors' judgement & Support for judgement \\
\hline $\begin{array}{l}\text { Random sequence genera- } \\
\text { tion (selection bias) }\end{array}$ & Unclear risk & Not described \\
\hline $\begin{array}{l}\text { Allocation concealment } \\
\text { (selection bias) }\end{array}$ & Unclear risk & Not described \\
\hline $\begin{array}{l}\text { Blinding (performance } \\
\text { bias and detection bias) }\end{array}$ & Low risk & $\begin{array}{l}\text { Double-blind: patients in the lower dose group took a physically indistinguish- } \\
\text { able placebo }\end{array}$ \\
\hline $\begin{array}{l}\text { Incomplete outcome data } \\
\text { (attrition bias) } \\
\text { All outcomes }\end{array}$ & Unclear risk & $\begin{array}{l}19 \% \text { of the } 0.5 \text { g/day group withdrew before the end of the study compared to } \\
14 \% \text { of the } 1.0 \text { g/day group and } 24 \% \text { of the 2.0 g/day group. Reasons for with- } \\
\text { drawal are described but are not attributed to individual treatment groups }\end{array}$ \\
\hline $\begin{array}{l}\text { Selective reporting (re- } \\
\text { porting bias) }\end{array}$ & Low risk & Expected outcomes are reported \\
\hline \begin{tabular}{l} 
Other bias \\
\hline
\end{tabular} & Low risk & \begin{tabular}{l} 
The study appears to be free of other sources of bias \\
\hline
\end{tabular}
\end{tabular}


Watanabe 2013

Methods

Phase III, double-blind, double-dummy, randomized, multicenter non-inferiority study

Patients were assessed at entry and once every 4 weeks until week 52

Participants

Patients (15 to 64 years) with documented diagnosis of ulcerative colitis. All patients were in remission (defined as UC-DAI score $\leq 2$ and rectal bleeding score of 0 ) at study entry, had experienced clinical relapse during the previous year, and were receiving $\leq 2.25 \mathrm{~g}$ of mesalazine or $4.5 \mathrm{~g}$ of salazosulfapyridine per day as maintenance therapy $(\mathrm{N}=301)$

Interventions

Prolonged-release oral mesalazine (Pentasa; Kyorin Pharmaceutical Co., Ltd., Tokyo, Japan) at doses of 1.5 to $2.25 \mathrm{~g} / \mathrm{d}$ once daily $(\mathrm{n}=152)$ or 3 times daily $(\mathrm{n}=149)$ for 52 weeks

Outcomes Primary outcome: remission at 52 weeks

Secondary outcomes: duration of remission, UC-DAI at final assessment, adherence, adverse events

\section{Notes}

\section{Risk of bias}

\begin{tabular}{lll}
\hline Bias & Authors' judgement & Support for judgement \\
\hline $\begin{array}{l}\text { Random sequence genera- } \\
\text { tion (selection bias) }\end{array}$ & Unclear risk & Not described \\
\hline $\begin{array}{l}\text { Allocation concealment } \\
\text { (selection bias) }\end{array}$ & Unclear risk & Not described \\
\hline $\begin{array}{l}\text { Blinding (performance } \\
\text { bias and detection bias) }\end{array}$ & Low risk & Double-blind, double dummy design \\
All outcomes & Low risk & $\begin{array}{l}\text { Drop-outs balanced across intervention groups with similar reasons for with- } \\
\text { drawal }\end{array}$ \\
\hline $\begin{array}{l}\text { Incomplete outcome data } \\
\text { (attrition bias) } \\
\text { All outcomes }\end{array}$ & Unclear risk & $\begin{array}{l}\text { Most expected outcomes were reported } \\
12 \text { serious adverse events were reported and a causal relationship with the } \\
\text { study drug was ruled out - but the authors did not report to which group these } \\
\text { patients belonged }\end{array}$ \\
\hline $\begin{array}{l}\text { Selective reporting (re- } \\
\text { porting bias) }\end{array}$ & Low risk & \begin{tabular}{l} 
The study appears to be free of other sources of bias \\
\hline \begin{tabular}{l} 
Other bias \\
\hline
\end{tabular}
\end{tabular}
\end{tabular}

Wright 1993

\begin{tabular}{ll} 
Methods & $\begin{array}{l}\text { Randomized, double-blind, placebo-controlled trial. Patients were assessed at entry, after } 3 \text { weeks, } \\
\text { and after } 3,6,9 \text { and } 12 \text { months. Sigmoidoscopy was performed at each visit. Biopsy was taken at entry, } \\
6 \text { months and } 1 \text { year }\end{array}$ \\
\hline Participants & $\begin{array}{l}\text { Patients, ages } 18 \text { to } 75 \text { years, with inactive ulcerative colitis who were asymptomatic for not less than } \\
\text { one week and not more than one month prior to entry }(\mathrm{N}=101) . \text { Steroid or SASP therapy was stopped } \\
\text { at least one week prior to entry }\end{array}$ \\
\hline
\end{tabular}


Wright 1993 (Continued)

Interventions $\quad$ Olsalazine $2 \mathrm{~g}$ /day $(500 \mathrm{mg}$ capsules 4 times per day; $\mathrm{n}=49)$ or matching placebo $(\mathrm{n}=52)$ for 1 year

Outcomes Clinical relapse was defined as a relapse of diarrhea (with or without blood and mucous) thought by the attending physician to warrant introduction of rectal or oral corticosteroids

Notes

\section{Risk of bias}

\begin{tabular}{|c|c|c|}
\hline Bias & Authors' judgement & Support for judgement \\
\hline $\begin{array}{l}\text { Random sequence genera- } \\
\text { tion (selection bias) }\end{array}$ & Unclear risk & Not described \\
\hline $\begin{array}{l}\text { Allocation concealment } \\
\text { (selection bias) }\end{array}$ & Low risk & Adequate \\
\hline $\begin{array}{l}\text { Blinding (performance } \\
\text { bias and detection bias) } \\
\text { All outcomes }\end{array}$ & Low risk & Double-blind: matching placebo \\
\hline $\begin{array}{l}\text { Incomplete outcome data } \\
\text { (attrition bias) } \\
\text { All outcomes }\end{array}$ & Low risk & $\begin{array}{l}3 \text { patients from the placebo group did not complete the study (1 lost top follow } \\
\text { up, } 1 \text { lost to compliance, } 1 \text { initial protocol exclusion) }\end{array}$ \\
\hline $\begin{array}{l}\text { Selective reporting (re- } \\
\text { porting bias) }\end{array}$ & Low risk & Expected outcomes were reported \\
\hline Other bias & Low risk & The study appears to be free of other sources of bias \\
\hline
\end{tabular}

UC-DAI = Ulcerative Colitis Disease Activity Index

Characteristics of excluded studies [ordered by study ID]

\begin{tabular}{ll}
\hline Study & Reason for exclusion \\
\hline Bardazzi 1994 & $\begin{array}{l}\text { Trial compares intermittent dosing of 5-ASA (2.4 g/day for first week of the month) with continuous } \\
\text { dosing of 5-ASA (1.6 g/day) for maintenance treatment }\end{array}$ \\
\hline d'Albasio 1997 & Trial compares the combination of oral 5-ASA and 5-ASA enemas with oral 5-ASA alone \\
\hline Dew 1982b & Treatment duration of less than 6 months (16 weeks) \\
\hline Eliakim 1990 & $\begin{array}{l}\text { Single-center report of patients who were abstracted from a larger multi-center trial (Rutgeerts } \\
\text { 1989) }\end{array}$ \\
\hline Ewe 1996 & Treatment duration of less than 6 months (10 days) \\
\hline Fernández-Bañares 1999 & Trial compares oral mesalamine to Plantago ovata seeds \\
\hline Frieri 2005 & Not an RCT \\
\hline Giaffer 1992b & Treatment duration of less than 6 months (3 months) \\
\hline Gionchetti 1990 & Treatment duration of less than 6 months \\
\hline \hline
\end{tabular}




\begin{tabular}{|c|c|}
\hline Study & Reason for exclusion \\
\hline Gionchetti 1996 & Treatment duration of less than 6 months ( 2 weeks) \\
\hline Green 2004 & Not a randomized controlled trial. No comparison group \\
\hline Hanauer 2009 & Not a RCT - open-label extension study \\
\hline Karamanolis 1996 & Treatment duration of less than 6 months ( 2 weeks) \\
\hline Kruis 1997 & Trial compares oral mesalazine (Salofalk) to probiotic (Esherichia coli Nissle 1917) \\
\hline Kruis 2004 & Trial compares oral mesalazine to probiotic (Esherichia coli Nissle 1917) \\
\hline Mani 1994 & Treatment duration of less than 6 months ( 4 weeks) \\
\hline Mantzaris 2004 & $\begin{array}{l}\text { Trial compares azathioprine monotherapy to combination of azathioprine and olsalazine for main- } \\
\text { tenance of remission in patients with steroid-dependent ulcerative colitis }\end{array}$ \\
\hline Odes 1997 & Not a RCT \\
\hline Osterman 2014 & Treatment duration of less than 6 months ( 6 weeks) \\
\hline Paoluzi 2002 & $\begin{array}{l}\text { Trial looks at } 4 \text { weeks of combined oral and topical 5-ASA (mesalazine) versus } 8 \text { weeks of combined } \\
\text { oral and topical 5-ASA (mesalazine) }\end{array}$ \\
\hline Papatheodoridis 1995 & Treatment duration of less than 6 months (14 days) \\
\hline Pelech 1998 & Trial compares oral mesalazine to probiotic (Esherichia coli Nissle 1917) \\
\hline Staerk Laursen 1990 & Treatment duration of less than 6 months ( 28 days) \\
\hline Stoa-Birketvedt 1999 & Treatment duration of less than 6 months (14 days) \\
\hline Tragnone 1996 & $\begin{array}{l}\text { Trial compares } 800 \mathrm{mg} \text { 5-ASA tablets (total dose } 1.6 \mathrm{~g} / \text { day) with } 400 \mathrm{mg} \text { 5-ASA tablets (total dose } \\
1.6 \mathrm{~g} / \text { day). Treatment duration of less than } 6 \text { months ( } 3 \text { months) }\end{array}$ \\
\hline Tzivras 1997 & Treatment duration of less than 6 months (14 days) \\
\hline Yokoyama 2007 & Trial compares oral 5-ASA with 5-ASA enemas \\
\hline Zocco 2006 & $\begin{array}{l}\text { Trial compares oral mesalazine to probiotic (Lactobacillus GG) to combination of oral mesalazine + } \\
\text { probiotic }\end{array}$ \\
\hline
\end{tabular}

\section{DATA AND ANALYSES}




\section{Comparison 1. 5-ASA versus placebo}

\begin{tabular}{|c|c|c|c|c|}
\hline Outcome or subgroup title & $\begin{array}{l}\text { No. of } \\
\text { studies }\end{array}$ & $\begin{array}{l}\text { No. of } \\
\text { partici- } \\
\text { pants }\end{array}$ & Statistical method & Effect size \\
\hline $\begin{array}{l}1 \text { Failure to Maintain Clinical } \\
\text { or Endoscopic Remission }\end{array}$ & 7 & 1298 & Risk Ratio (M-H, Fixed, 95\% Cl) & $0.69[0.62,0.77]$ \\
\hline 1.1 Dose of 5-ASA: <1 g & 1 & 133 & Risk Ratio (M-H, Fixed, 95\% Cl) & $0.77[0.59,1.00]$ \\
\hline 1.2 Dose of 5-ASA: 1 - $1.9 \mathrm{~g}$ & 5 & 859 & Risk Ratio (M-H, Fixed, 95\% Cl) & $0.65[0.56,0.76]$ \\
\hline 1.3 Dose of 5-ASA: >or=2 g & 2 & 306 & Risk Ratio (M-H, Fixed, 95\% Cl) & $0.73[0.60,0.89]$ \\
\hline $\begin{array}{l}2 \text { Development of Any Ad- } \\
\text { verse Event }\end{array}$ & 4 & 875 & Risk Ratio (M-H, Random, 95\% Cl) & $0.98[0.69,1.39]$ \\
\hline 2.1 Dose of 5-ASA: <1 g & 1 & 133 & Risk Ratio (M-H, Random, 95\% Cl) & $0.82[0.51,1.31]$ \\
\hline 2.2 Dose of 5-ASA: 1 - $1.9 \mathrm{~g}$ & 2 & 436 & Risk Ratio (M-H, Random, 95\% Cl) & $1.02[0.86,1.20]$ \\
\hline 2.3 Dose of 5-ASA: $>$ or $=2 \mathrm{~g}$ & 2 & 306 & Risk Ratio (M-H, Random, 95\% Cl) & $1.69[0.14,20.58]$ \\
\hline $\begin{array}{l}3 \text { Development of Any Ad- } \\
\text { verse Event (Sensitivity } \\
\text { analysis) }\end{array}$ & 3 & 774 & Risk Ratio (M-H, Random, 95\% Cl) & $0.94[0.77,1.15]$ \\
\hline 3.1 Dose of 5-ASA: <1 g & 1 & 133 & Risk Ratio (M-H, Random, 95\% Cl) & $0.82[0.51,1.31]$ \\
\hline 3.2 Dose of 5-ASA: 1 - $1.9 \mathrm{~g}$ & 2 & 436 & Risk Ratio (M-H, Random, 95\% Cl) & $1.02[0.86,1.20]$ \\
\hline 3.3 Dose of 5-ASA: >or $=2 \mathrm{~g}$ & 1 & 205 & Risk Ratio (M-H, Random, 95\% Cl) & $0.52[0.25,1.12]$ \\
\hline $\begin{array}{l}4 \text { Withdrawal from Study due } \\
\text { to Adverse Event }\end{array}$ & 6 & 1197 & Risk Ratio (M-H, Fixed, 95\% Cl) & $1.34[0.78,2.30]$ \\
\hline 4.1 Dose of 5-ASA: $<1 \mathrm{~g}$ & 1 & 133 & Risk Ratio (M-H, Fixed, 95\% Cl) & $1.43[0.15,13.38]$ \\
\hline 4.2 Dose of 5-ASA: 1 - $1.9 \mathrm{~g}$ & 4 & 758 & Risk Ratio (M-H, Fixed, 95\% Cl) & $1.05[0.50,2.23]$ \\
\hline 4.3 Dose of 5-ASA: >or=2 g & 2 & 306 & Risk Ratio (M-H, Fixed, 95\% Cl) & $1.80[0.78,4.15]$ \\
\hline $\begin{array}{l}5 \text { Withdrawal from Study due } \\
\text { to Adverse Event (Sensitivity } \\
\text { analysis) }\end{array}$ & 5 & 1096 & Risk Ratio (M-H, Fixed, 95\% Cl) & $0.86[0.46,1.63]$ \\
\hline 5.1 Dose of $5-A S A:<1 \mathrm{~g}$ & 1 & 133 & Risk Ratio (M-H, Fixed, 95\% Cl) & $1.43[0.15,13.38]$ \\
\hline 5.2 Dose of 5-ASA: 1 - $1.9 \mathrm{~g}$ & 4 & 758 & Risk Ratio (M-H, Fixed, 95\% Cl) & $1.05[0.50,2.23]$ \\
\hline 5.3 Dose of 5-ASA: >or $=2 \mathrm{~g}$ & 1 & 205 & Risk Ratio (M-H, Fixed, 95\% Cl) & $0.33[0.07,1.60]$ \\
\hline $\begin{array}{l}6 \text { Exclusion/Withdrawal after } \\
\text { Entry (not due to relapse) }\end{array}$ & 5 & 1074 & Risk Ratio (M-H, Fixed, 95\% Cl) & $1.13[0.88,1.44]$ \\
\hline 6.1 Dose of $5-A S A:<1 \mathrm{~g}$ & 1 & 177 & Risk Ratio (M-H, Fixed, 95\% Cl) & $0.90[0.58,1.40]$ \\
\hline
\end{tabular}




\begin{tabular}{lllll}
\hline Outcome or subgroup title & $\begin{array}{l}\text { No. of } \\
\text { studies }\end{array}$ & $\begin{array}{l}\text { No. of } \\
\text { partici- } \\
\text { pants }\end{array}$ & Statistical method & Effect size \\
\hline 6.2 Dose of 5-ASA: $1-1.9 \mathrm{~g}$ & 3 & 591 & Risk Ratio $(\mathrm{M}-\mathrm{H}$, Fixed, 95\% Cl) & $1.22[0.87,1.71]$ \\
\hline 6.3 Dose of 5-ASA: >or=2 g & 2 & 306 & Risk Ratio (M-H, Fixed, 95\% Cl) & $1.26[0.69,2.29]$ \\
\hline
\end{tabular}

\section{Analysis 1.1. Comparison 1 5-ASA versus placebo, Outcome 1 Failure to Maintain Clinical or Endoscopic Remission.}

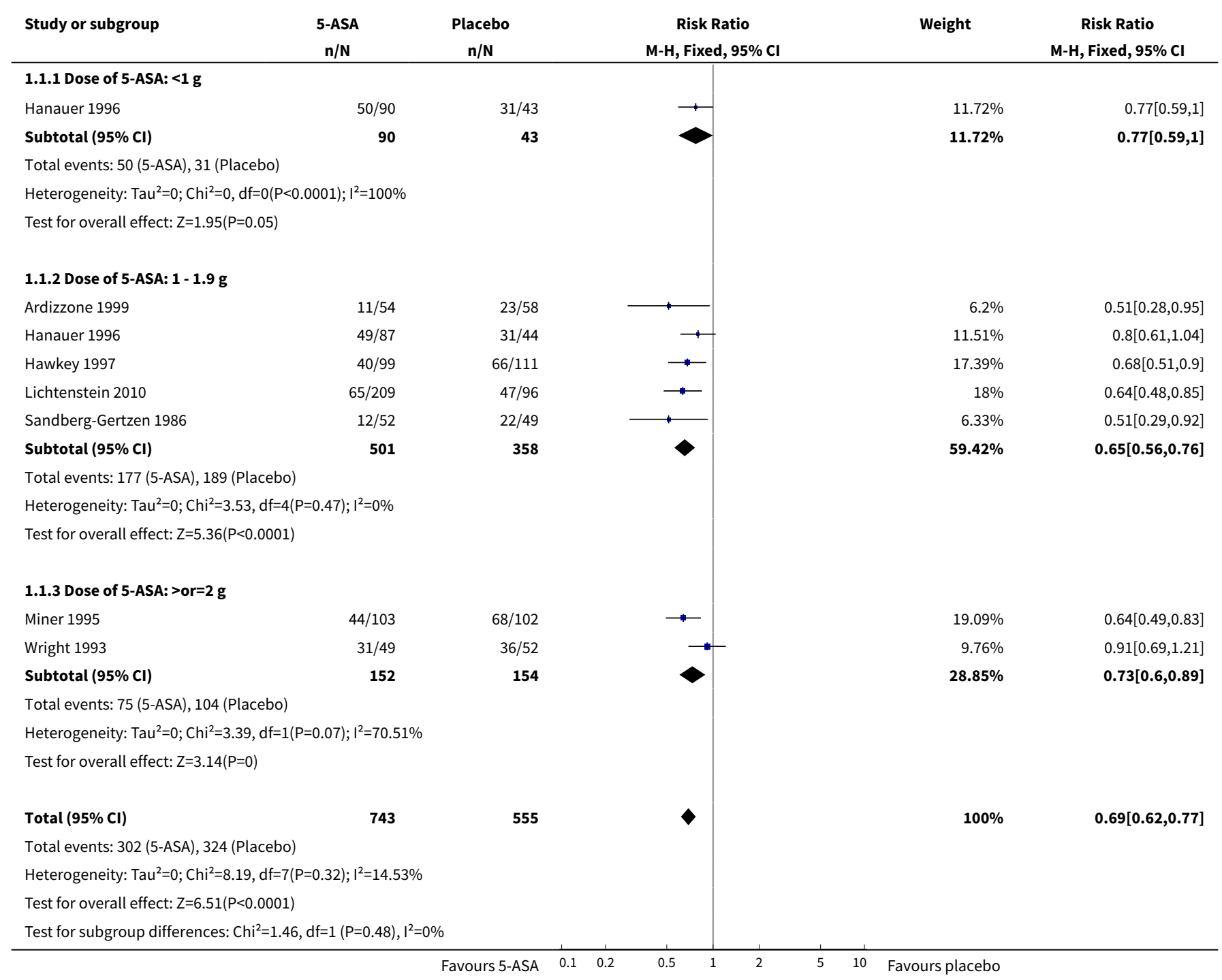


Analysis 1.2. Comparison 1 5-ASA versus placebo, Outcome 2 Development of Any Adverse Event.

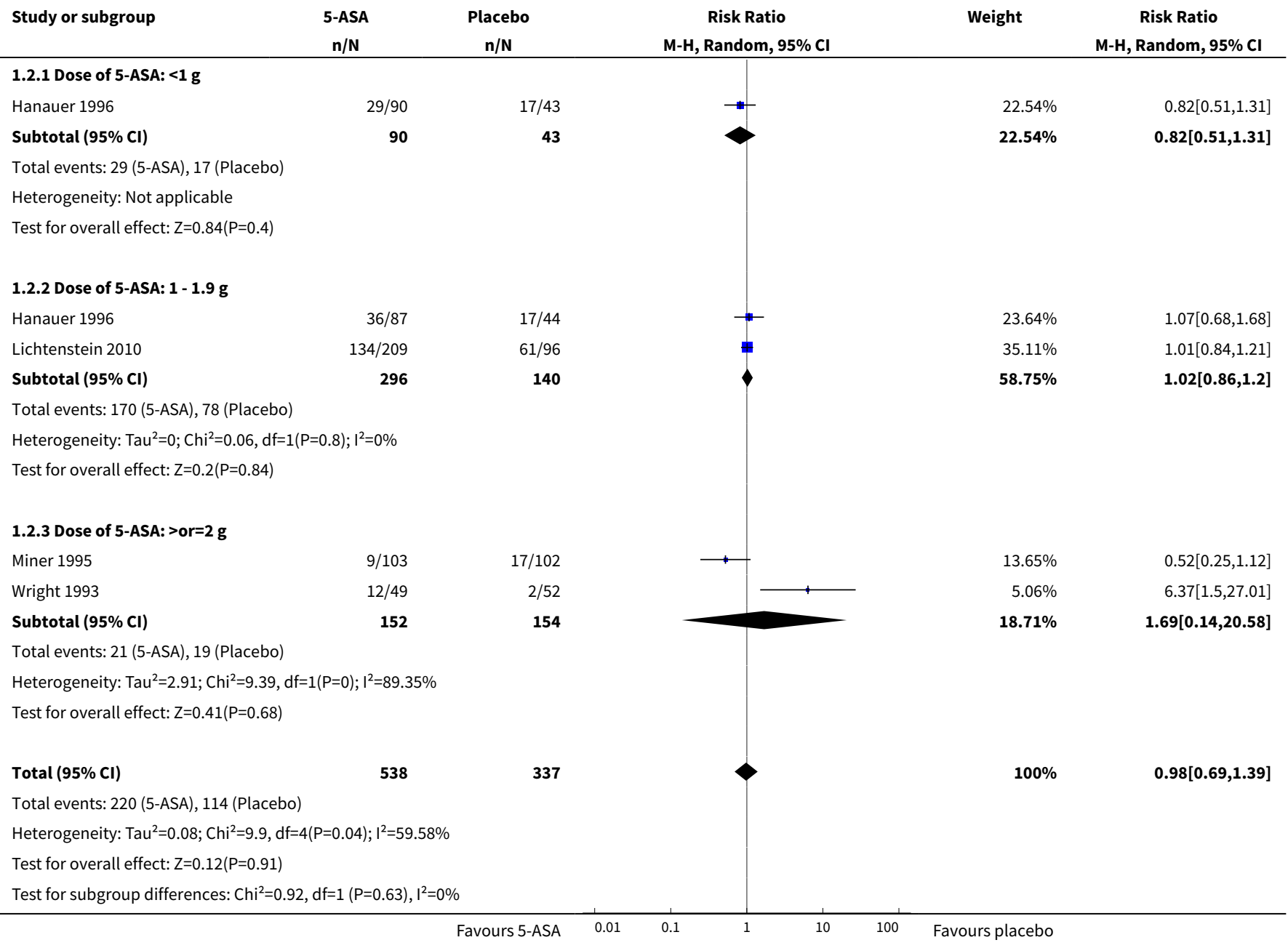

\section{Analysis 1.3. Comparison 1 5-ASA versus placebo, Outcome} 3 Development of Any Adverse Event (Sensitivity analysis).

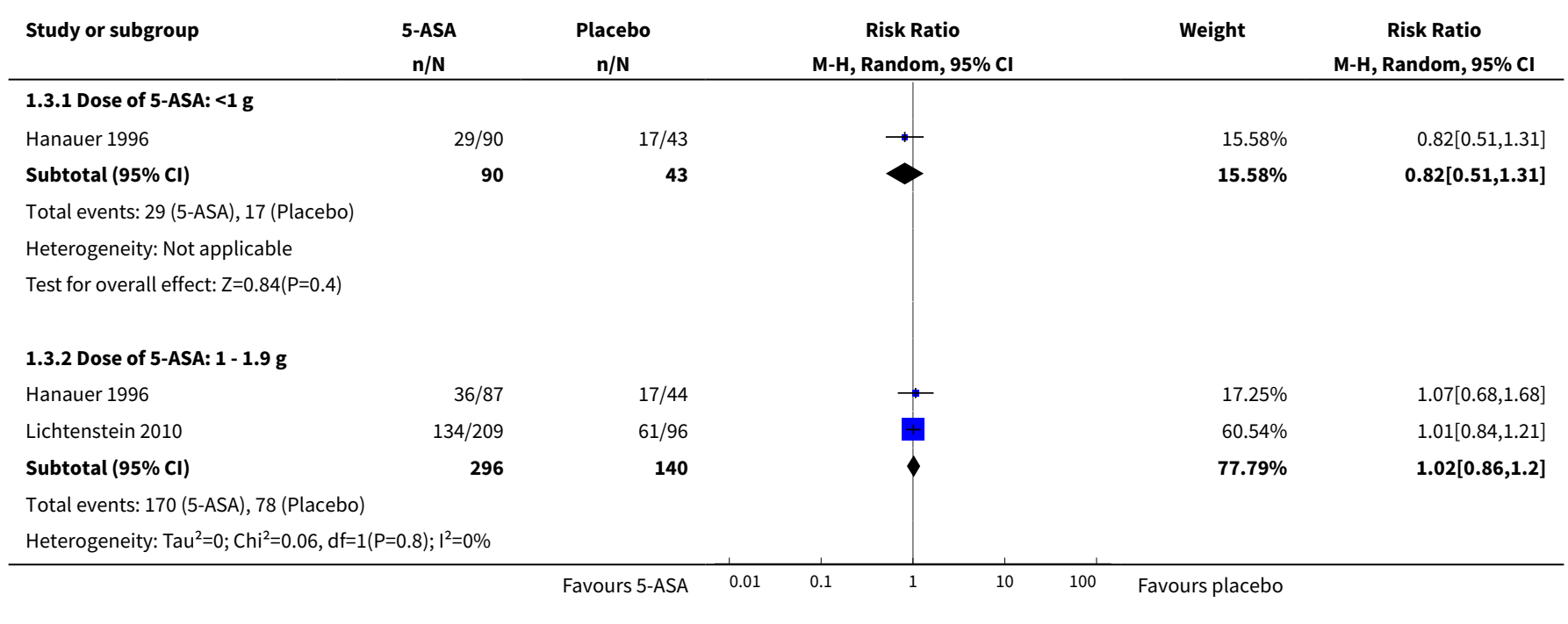




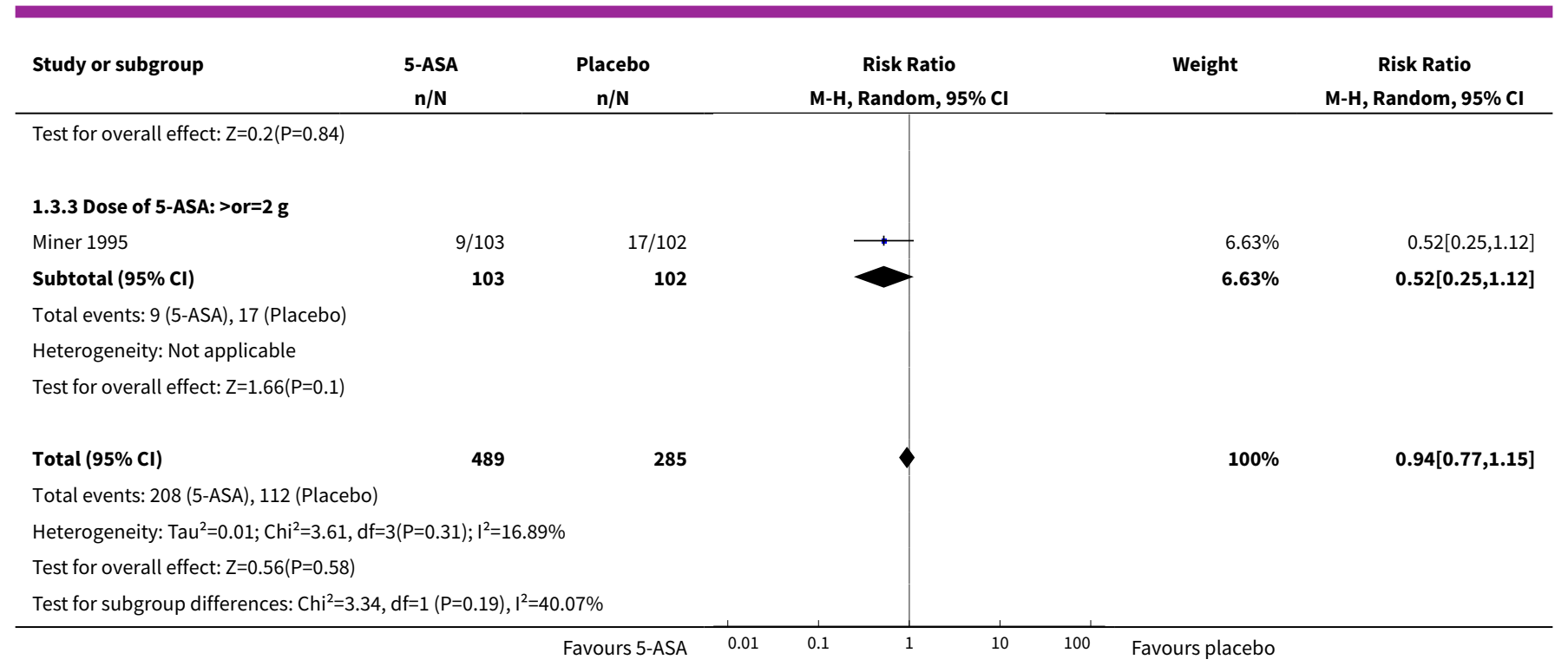

Analysis 1.4. Comparison 15-ASA versus placebo, Outcome 4 Withdrawal from Study due to Adverse Event.

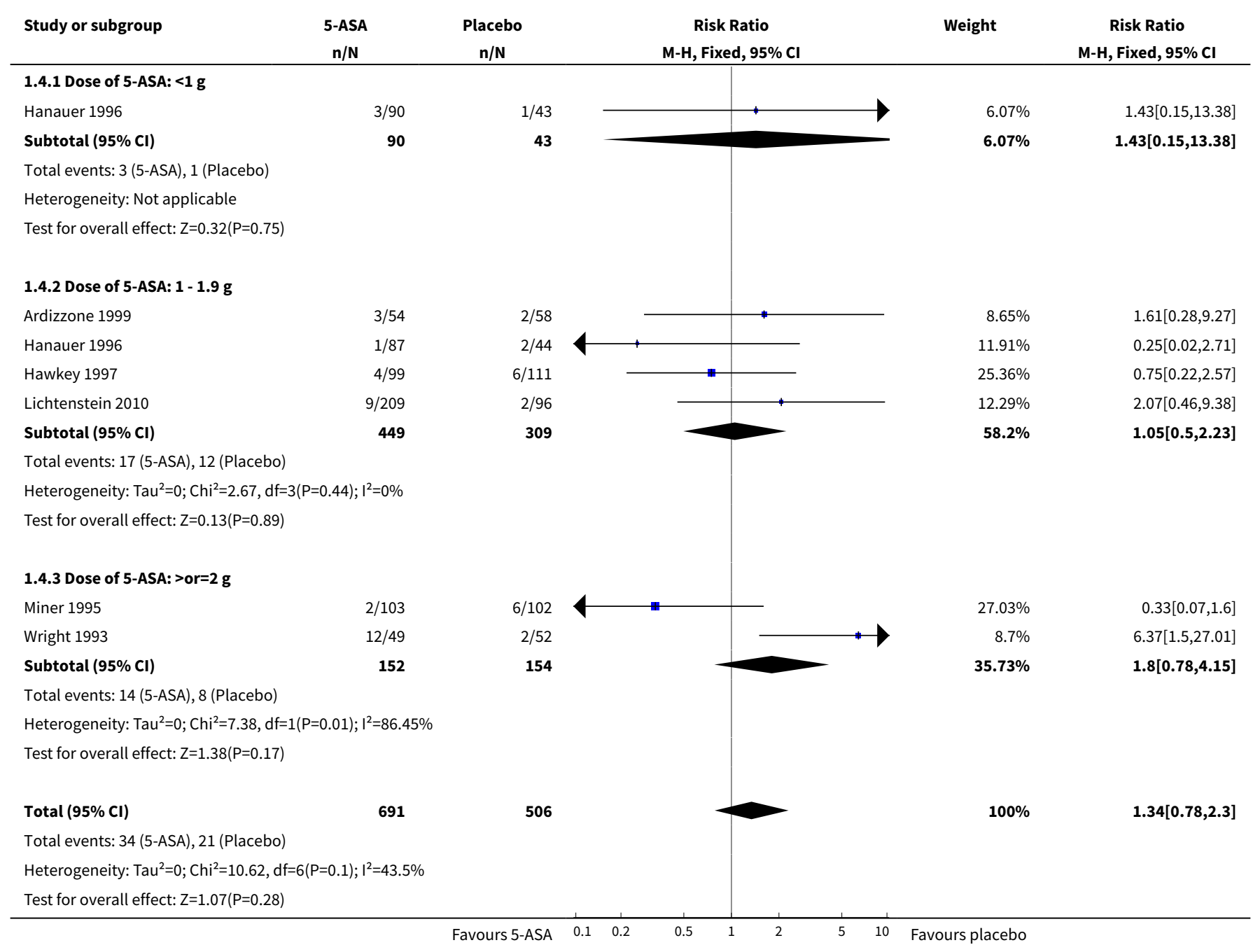




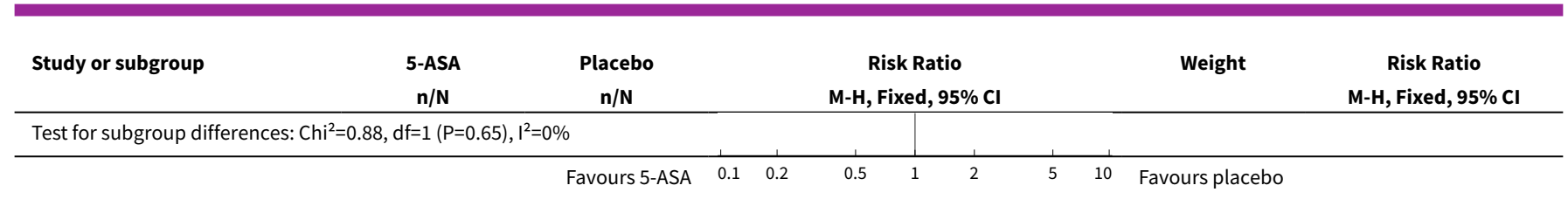

Analysis 1.5. Comparison 1 5-ASA versus placebo, Outcome 5 Withdrawal from Study due to Adverse Event (Sensitivity analysis).

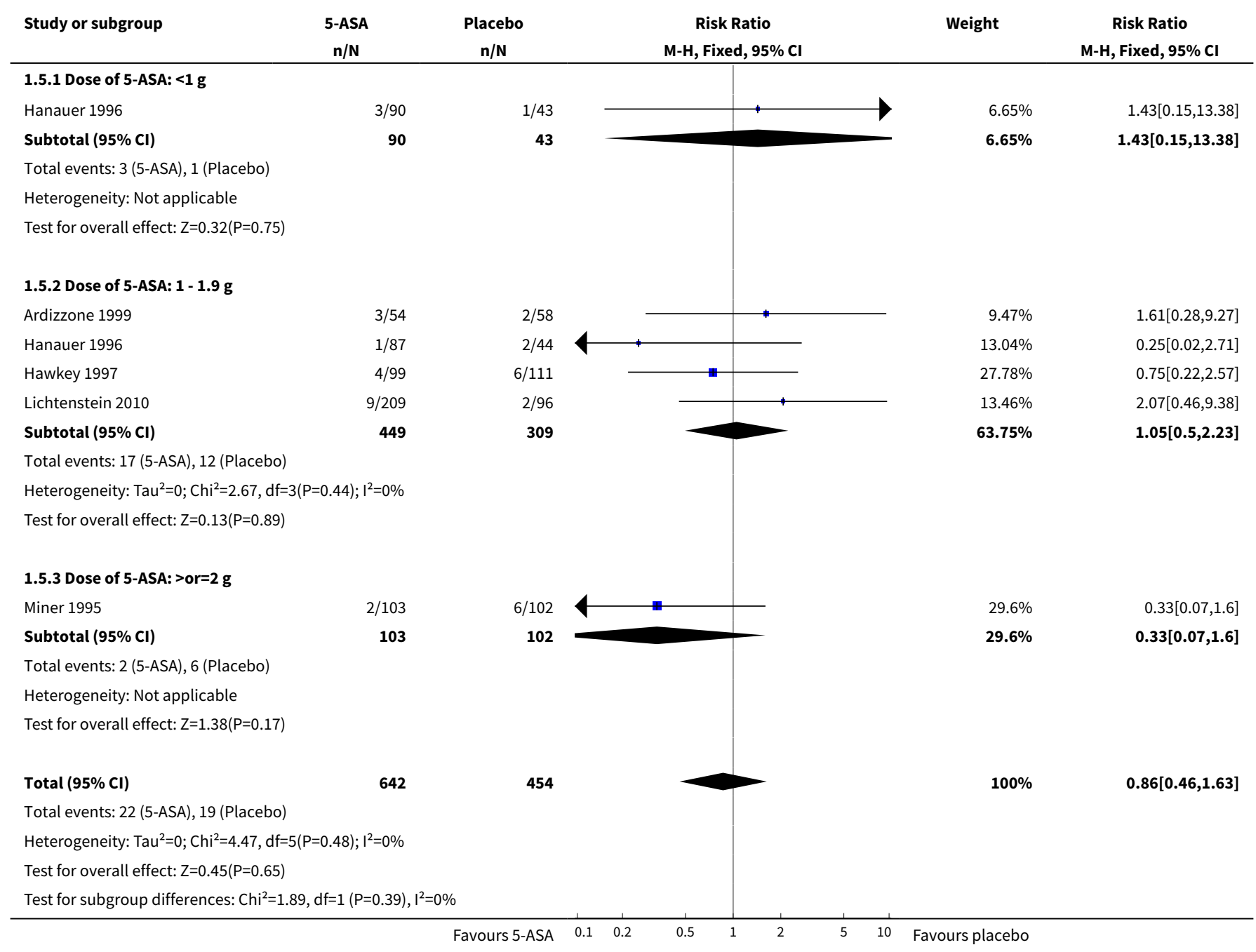

Analysis 1.6. Comparison 1 5-ASA versus placebo, Outcome 6 Exclusion/Withdrawal after Entry (not due to relapse).

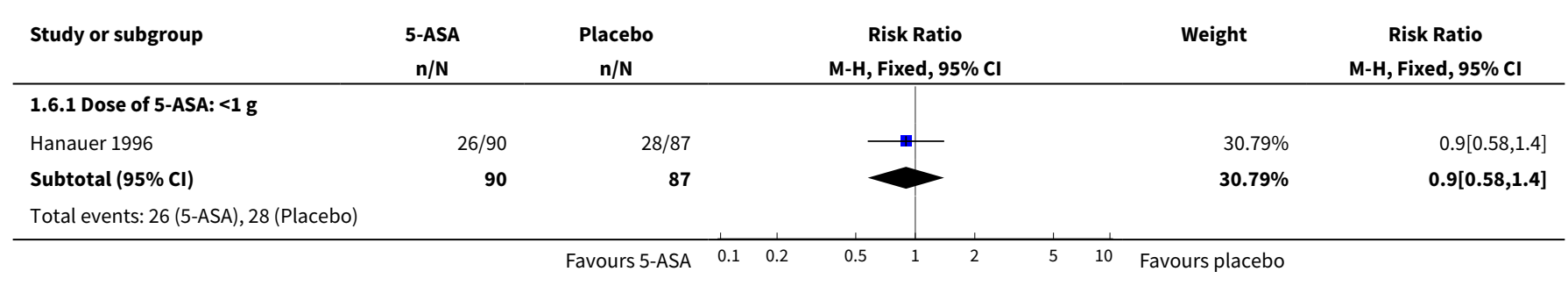




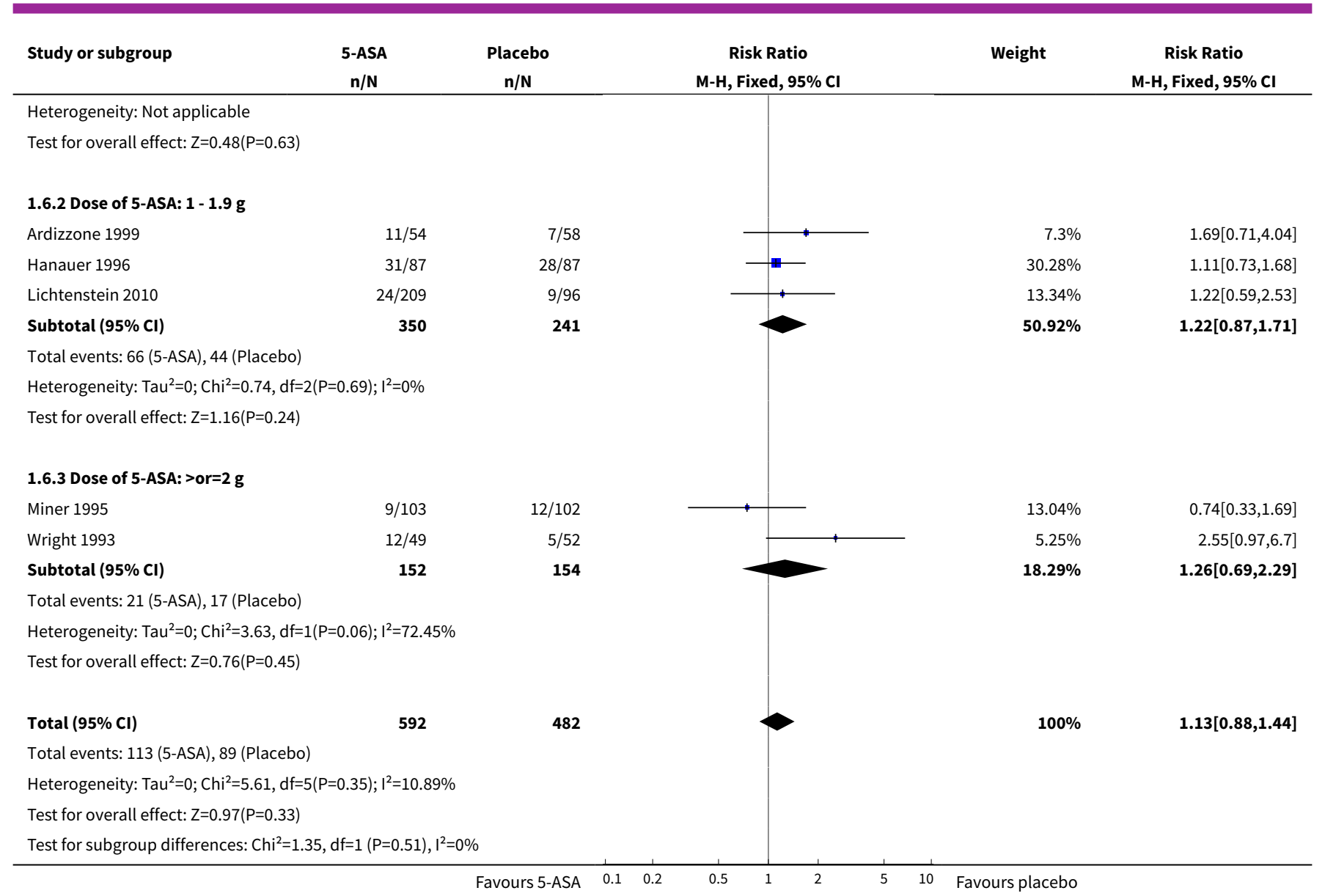

\section{Comparison 2. 5-ASA versus sulfasalazine}

\begin{tabular}{|c|c|c|c|c|}
\hline Outcome or subgroup title & $\begin{array}{l}\text { No. of } \\
\text { studies }\end{array}$ & $\begin{array}{l}\text { No. of } \\
\text { partici- } \\
\text { pants }\end{array}$ & Statistical method & Effect size \\
\hline $\begin{array}{l}1 \text { Failure to Maintain Clinical or Endoscopic } \\
\text { Remission }\end{array}$ & 12 & 1655 & Risk Ratio (M-H, Fixed, 95\% Cl) & $1.14[1.03,1.27]$ \\
\hline $\begin{array}{l}2 \text { Failure to Maintain Remission (trials with- } \\
\text { out olsalazine) }\end{array}$ & 7 & 749 & Risk Ratio (M-H, Fixed, 95\% Cl) & $1.08[0.92,1.26]$ \\
\hline 3 Development of Any Adverse Event & 7 & 1138 & Risk Ratio (M-H, Fixed, 95\% Cl) & $1.07[0.82,1.40]$ \\
\hline $\begin{array}{l}4 \text { Withdrawal from Study due to Adverse } \\
\text { Event }\end{array}$ & 10 & 1585 & Risk Ratio (M-H, Fixed, 95\% Cl) & $1.27[0.87,1.87]$ \\
\hline $\begin{array}{l}5 \text { Exclusion/Withdrawal after Entry (not due } \\
\text { to relapse) }\end{array}$ & 9 & 1497 & Risk Ratio (M-H, Fixed, 95\% Cl) & $1.30[1.04,1.63]$ \\
\hline
\end{tabular}


Analysis 2.1. Comparison 2 5-ASA versus sulfasalazine, Outcome 1 Failure to Maintain Clinical or Endoscopic Remission.

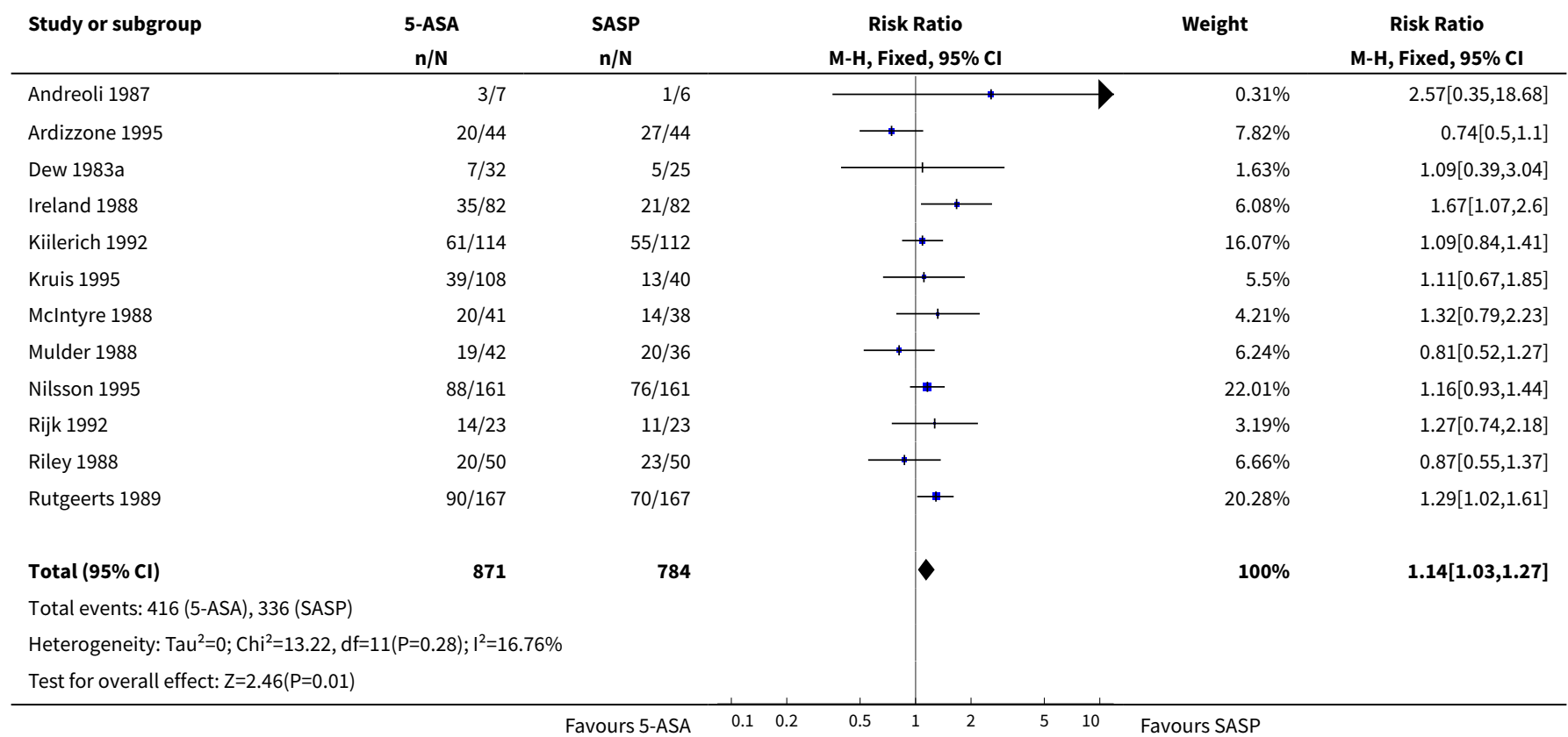

Analysis 2.2. Comparison 2 5-ASA versus sulfasalazine, Outcome 2 Failure to Maintain Remission (trials without olsalazine).

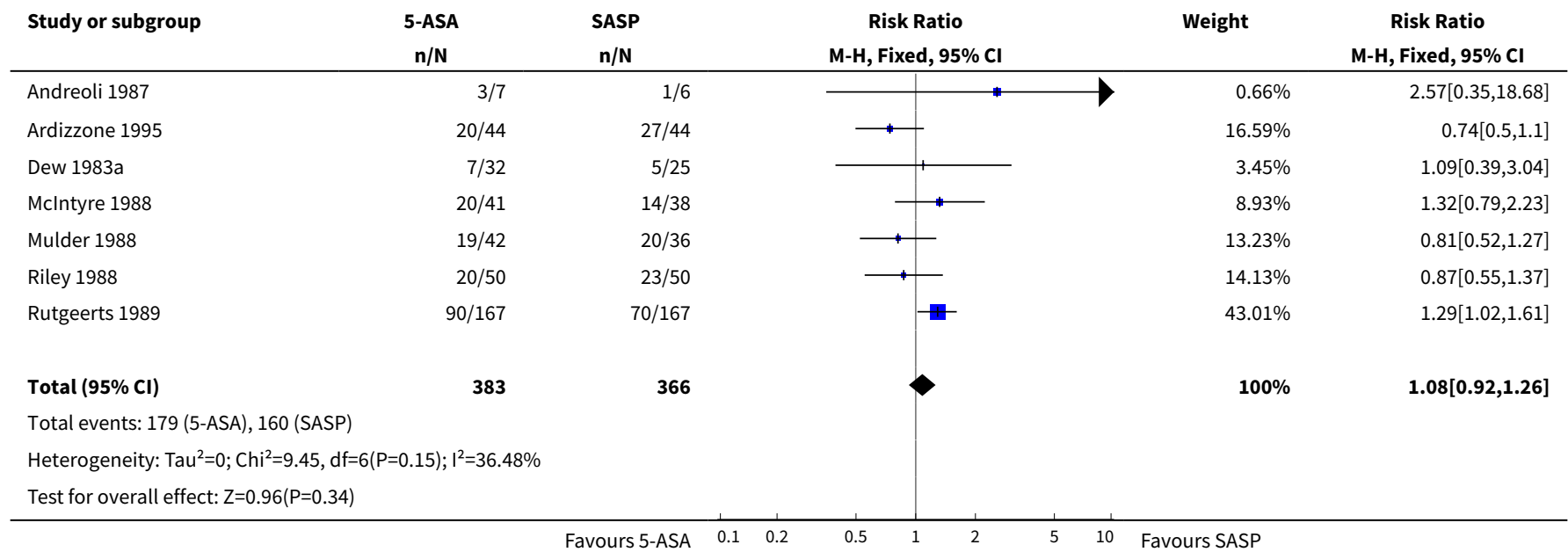

Analysis 2.3. Comparison 2 5-ASA versus sulfasalazine, Outcome 3 Development of Any Adverse Event.

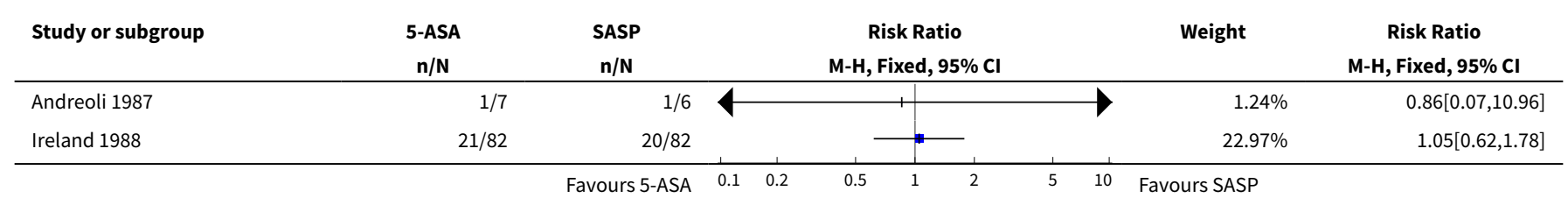




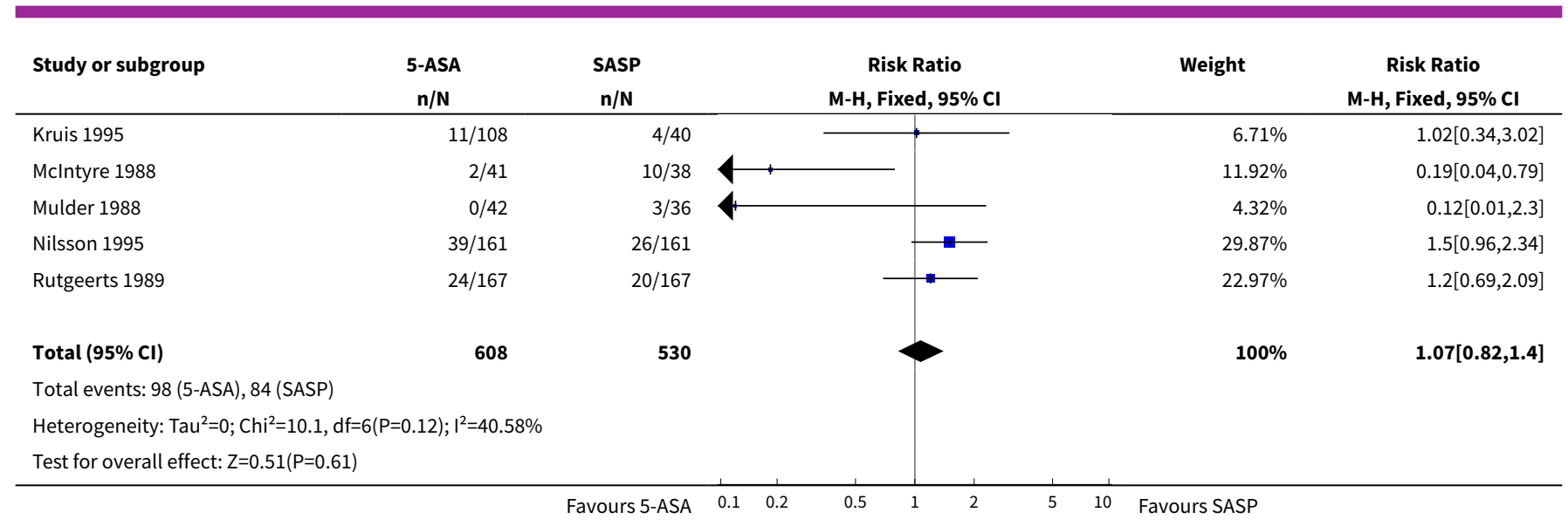

\section{Analysis 2.4. Comparison 2 5-ASA versus sulfasalazine, Outcome 4 Withdrawal from Study due to Adverse Event.}

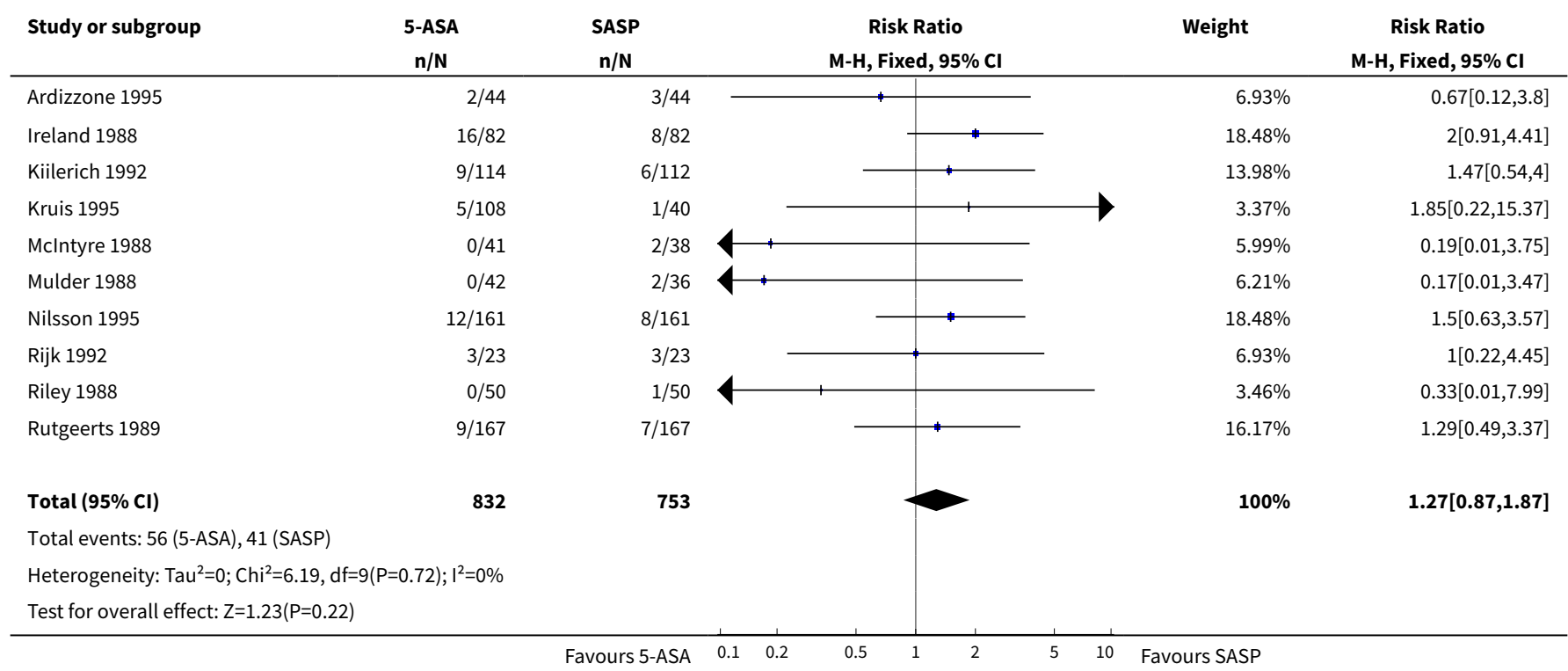

Analysis 2.5. Comparison 2 5-ASA versus sulfasalazine, Outcome 5 Exclusion/Withdrawal after Entry (not due to relapse).

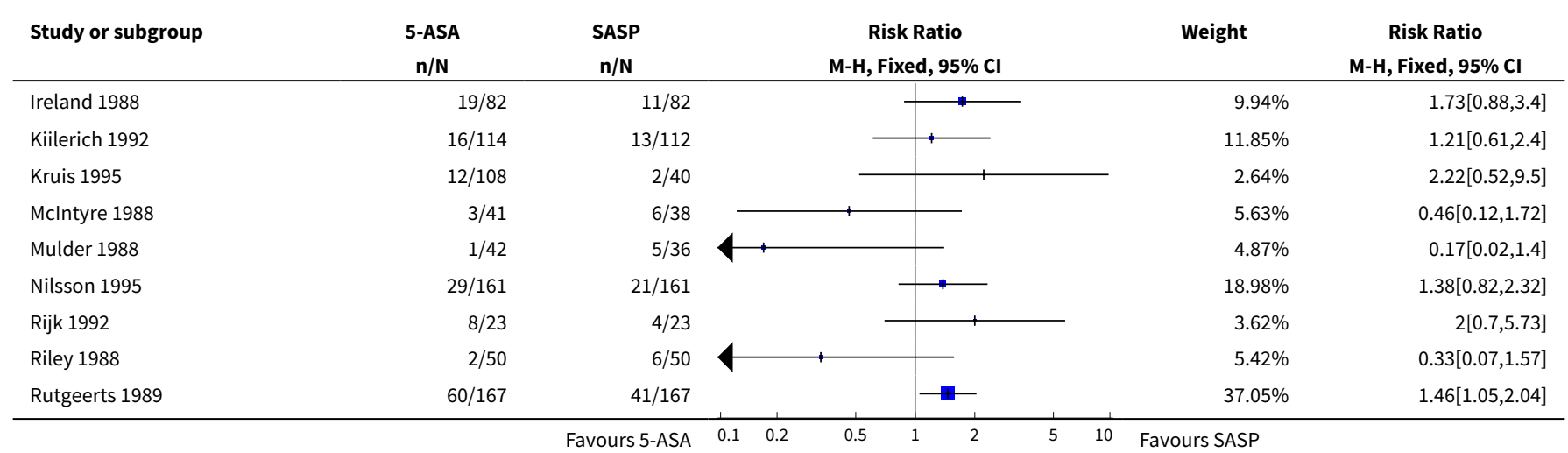




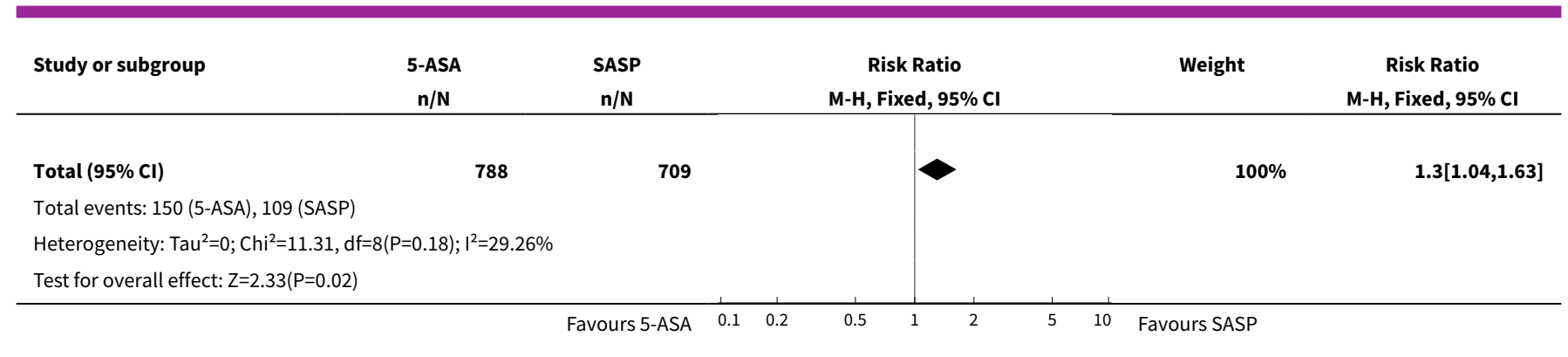

\section{Comparison 3. Once daily versus conventional dosing}

\begin{tabular}{|c|c|c|c|c|}
\hline Outcome or subgroup title & $\begin{array}{l}\text { No. of } \\
\text { studies }\end{array}$ & $\begin{array}{l}\text { No. of } \\
\text { partici- } \\
\text { pants }\end{array}$ & Statistical method & Effect size \\
\hline $\begin{array}{l}1 \text { Failure to Maintain Clinical or Endo- } \\
\text { scopic Remission at } 6 \text { months }\end{array}$ & 3 & 1871 & Risk Ratio (M-H, Fixed, 95\% Cl) & $1.02[0.85,1.23]$ \\
\hline 1.1 Asacol (OD vs BID or TID) & 2 & 1045 & Risk Ratio (M-H, Fixed, 95\% Cl) & $1.10[0.83,1.46]$ \\
\hline 1.2 MMX (OD) vs Asacol (BID) & 1 & 826 & Risk Ratio (M-H, Fixed, 95\% Cl) & $0.96[0.75,1.23]$ \\
\hline $\begin{array}{l}2 \text { Failure to Maintain Clinical or Endo- } \\
\text { scopic Remission at } 12 \text { months }\end{array}$ & 8 & 3127 & Risk Ratio (M-H, Fixed, 95\% Cl) & $0.91[0.82,1.01]$ \\
\hline 2.1 Asacol (OD vs BID or TID) & 3 & 1256 & Risk Ratio (M-H, Fixed, 95\% CI) & $0.95[0.79,1.15]$ \\
\hline 2.2 MMX (OD) vs Asacol (BID) & 1 & 331 & Risk Ratio (M-H, Fixed, 95\% Cl) & $0.99[0.74,1.33]$ \\
\hline 2.3 Pentasa (OD vs BID) & 2 & 654 & Risk Ratio (M-H, Fixed, 95\% Cl) & $0.75[0.60,0.93]$ \\
\hline 2.4 MMX (OD vs BID) & 1 & 451 & Risk Ratio (M-H, Fixed, 95\% Cl) & $1.13[0.87,1.47]$ \\
\hline 2.5 Salofalk granules (OD vs TID) & 1 & 435 & Risk Ratio (M-H, Fixed, 95\% Cl) & $0.81[0.60,1.10]$ \\
\hline $\begin{array}{l}3 \text { Failure to adhere to study medica- } \\
\text { tion regimen at study endpoint }\end{array}$ & 8 & 2126 & Risk Ratio (M-H, Random, 95\% Cl) & $1.18[0.69,2.03]$ \\
\hline $\begin{array}{l}4 \text { Failure to adhere to study medica- } \\
\text { tion regimen (Sensitivity analysis - ex- } \\
\text { cluding outliers) }\end{array}$ & 6 & 1462 & Risk Ratio (M-H, Fixed, 95\% Cl) & $1.22[0.91,1.64]$ \\
\hline 5 Development of Any Adverse Event & 6 & 2714 & Risk Ratio (M-H, Fixed, 95\% Cl) & $1.00[0.92,1.08]$ \\
\hline 6 Withdrawal due to adverse event & 7 & 3737 & Risk Ratio (M-H, Fixed, 95\% Cl) & $1.31[0.80,2.13]$ \\
\hline $\begin{array}{l}7 \text { Exclusion/Withdrawal after Entry } \\
\text { (not due to relapse) }\end{array}$ & 7 & 3737 & Risk Ratio (M-H, Fixed, 95\% Cl) & $0.99[0.85,1.15]$ \\
\hline
\end{tabular}


Analysis 3.1. Comparison 3 Once daily versus conventional dosing, Outcome 1 Failure to Maintain Clinical or Endoscopic Remission at 6 months.

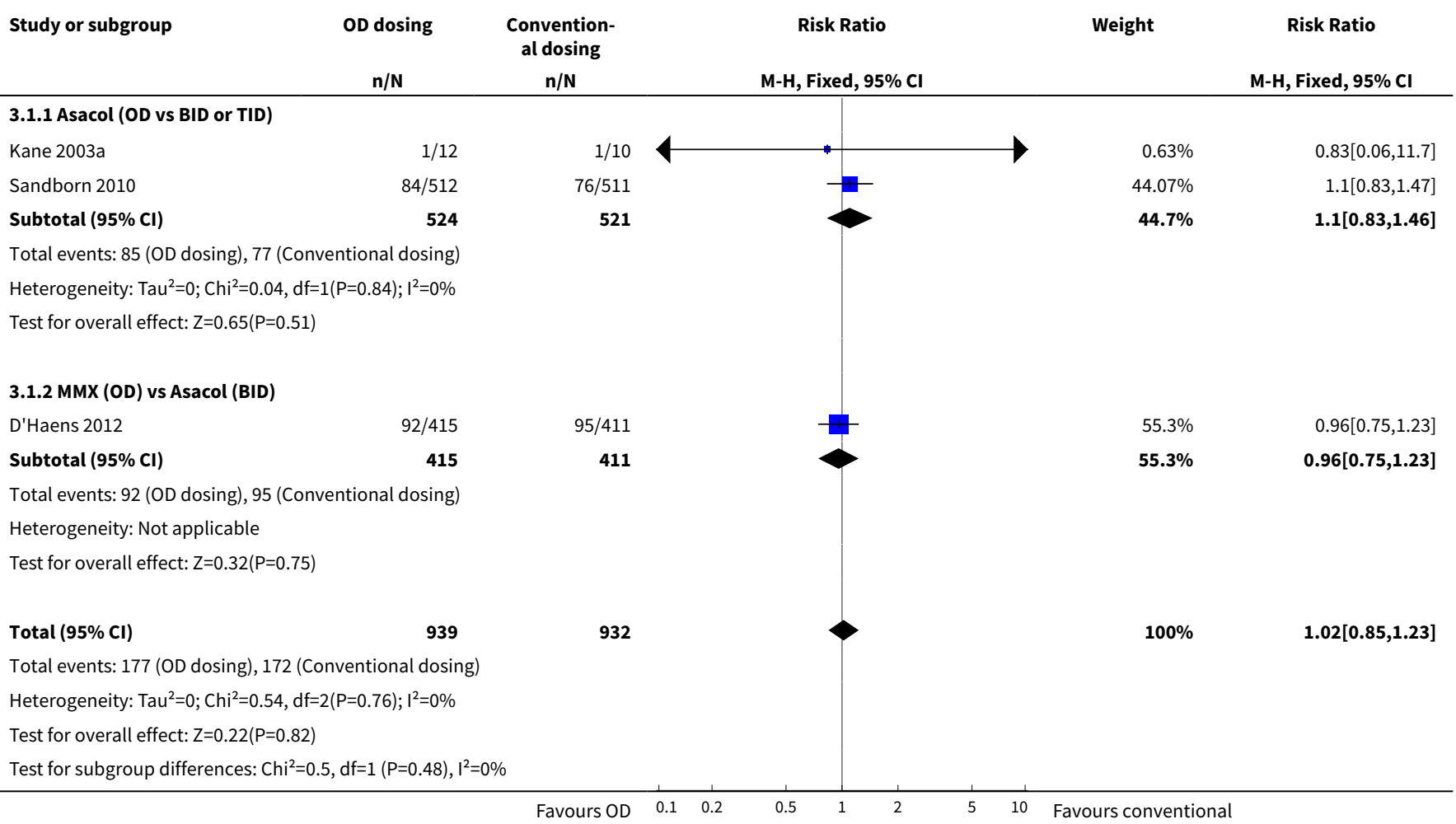

\section{Analysis 3.2. Comparison 3 Once daily versus conventional dosing, Outcome} 2 Failure to Maintain Clinical or Endoscopic Remission at 12 months.

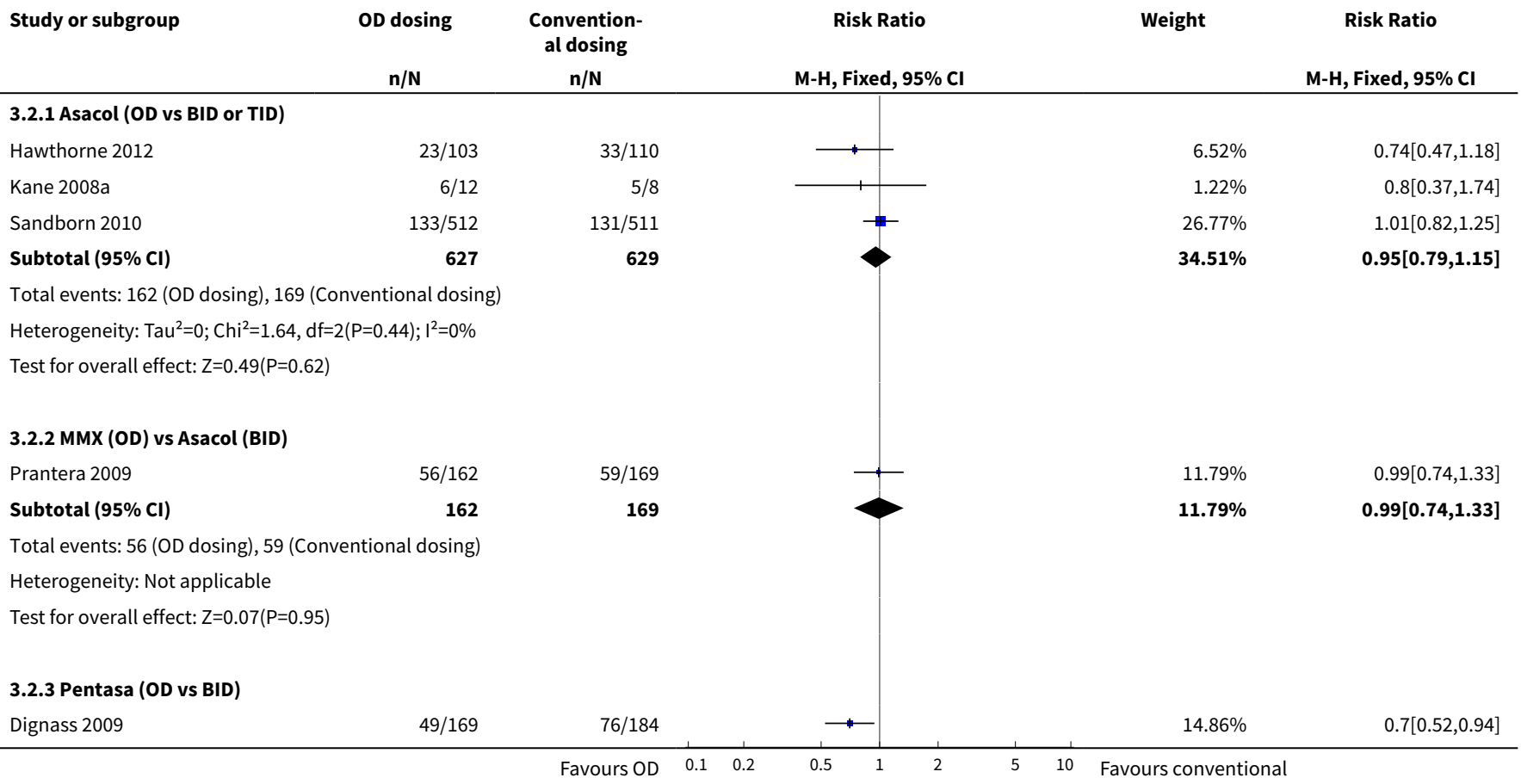




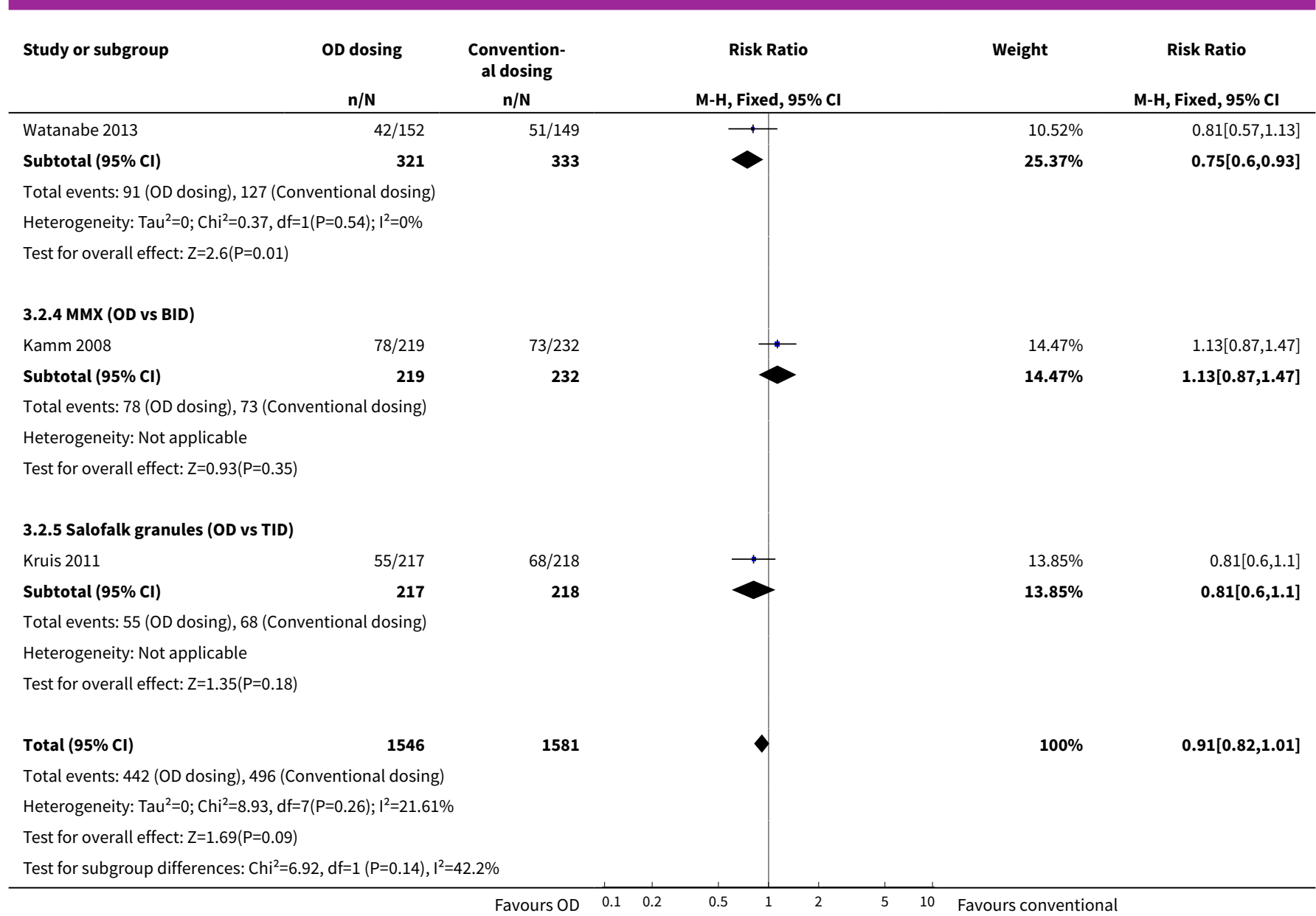

Analysis 3.3. Comparison 3 Once daily versus conventional dosing, Outcome 3 Failure to adhere to study medication regimen at study endpoint.

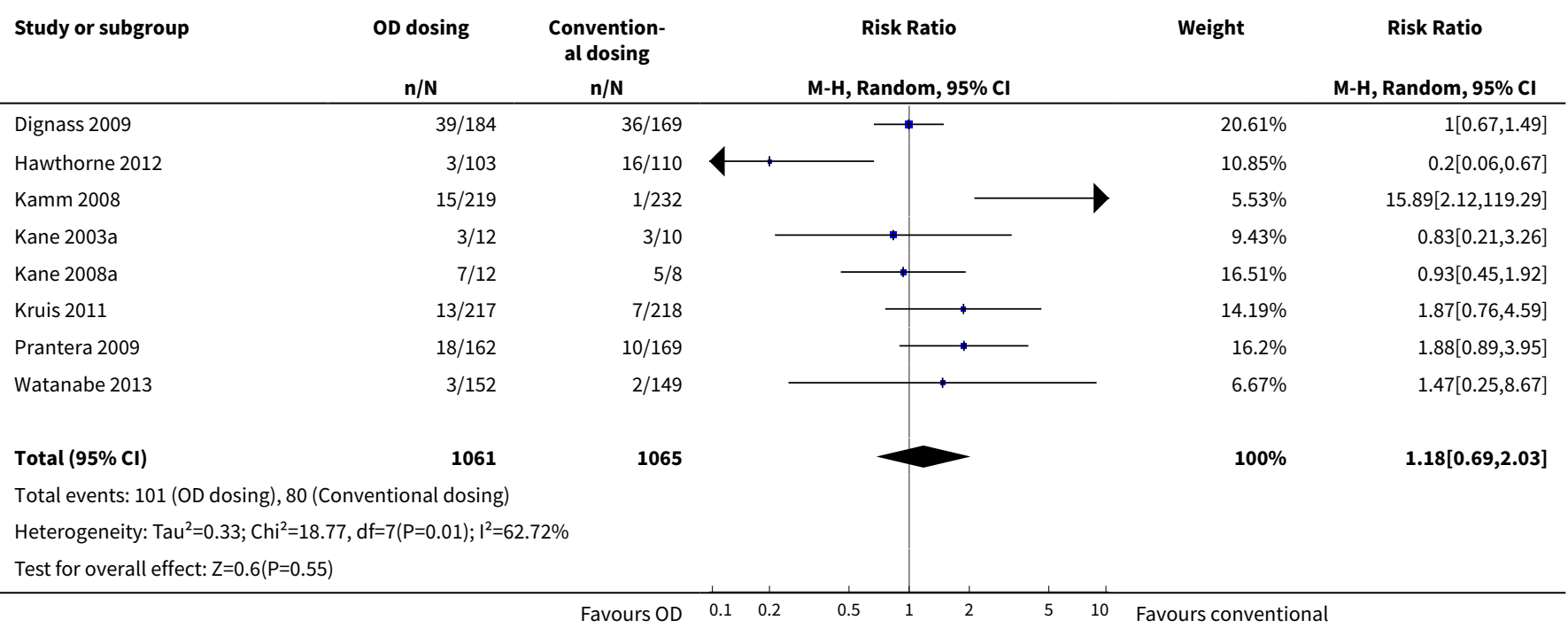


Analysis 3.4. Comparison 3 Once daily versus conventional dosing, Outcome 4 Failure to adhere to study medication regimen (Sensitivity analysis - excluding outliers).

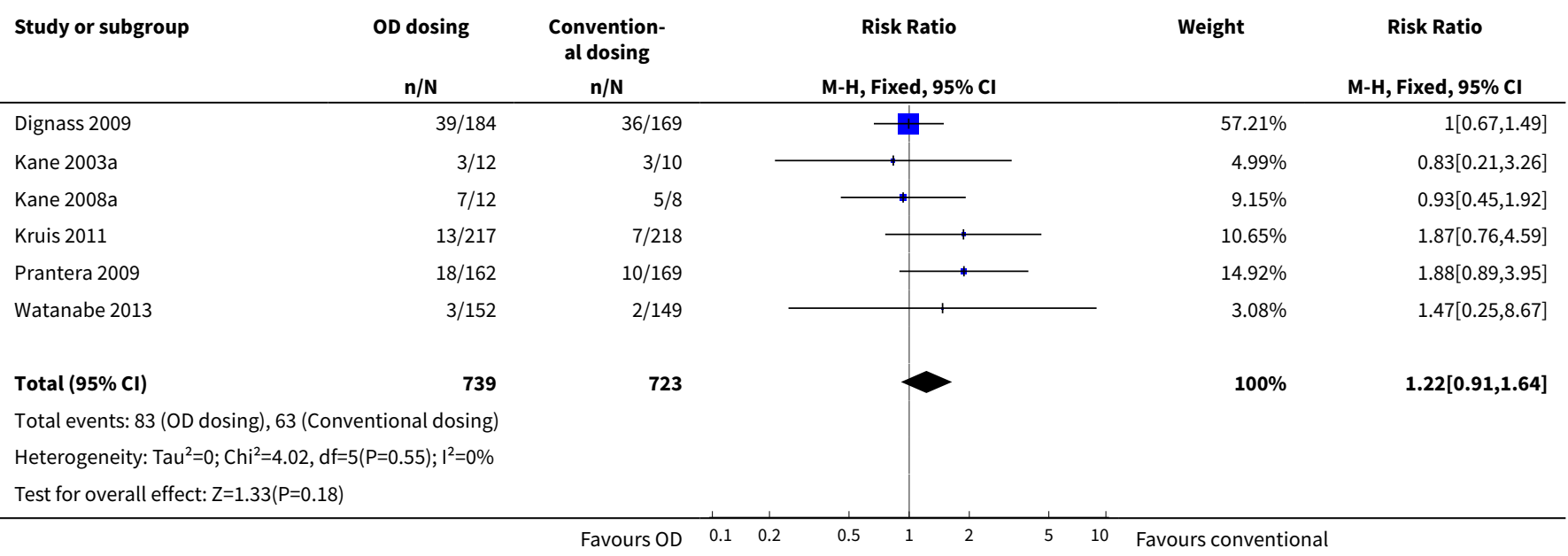

Analysis 3.5. Comparison 3 Once daily versus conventional dosing, Outcome 5 Development of Any Adverse Event.

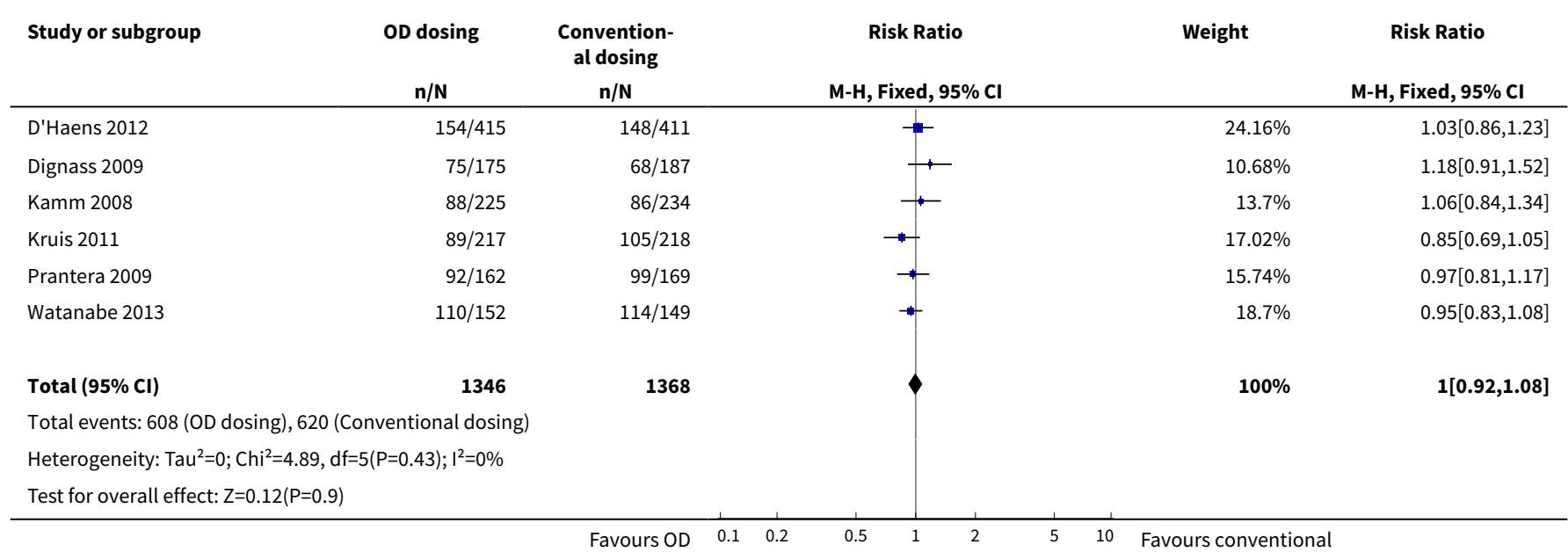

Analysis 3.6. Comparison 3 Once daily versus conventional dosing, Outcome 6 Withdrawal due to adverse event.

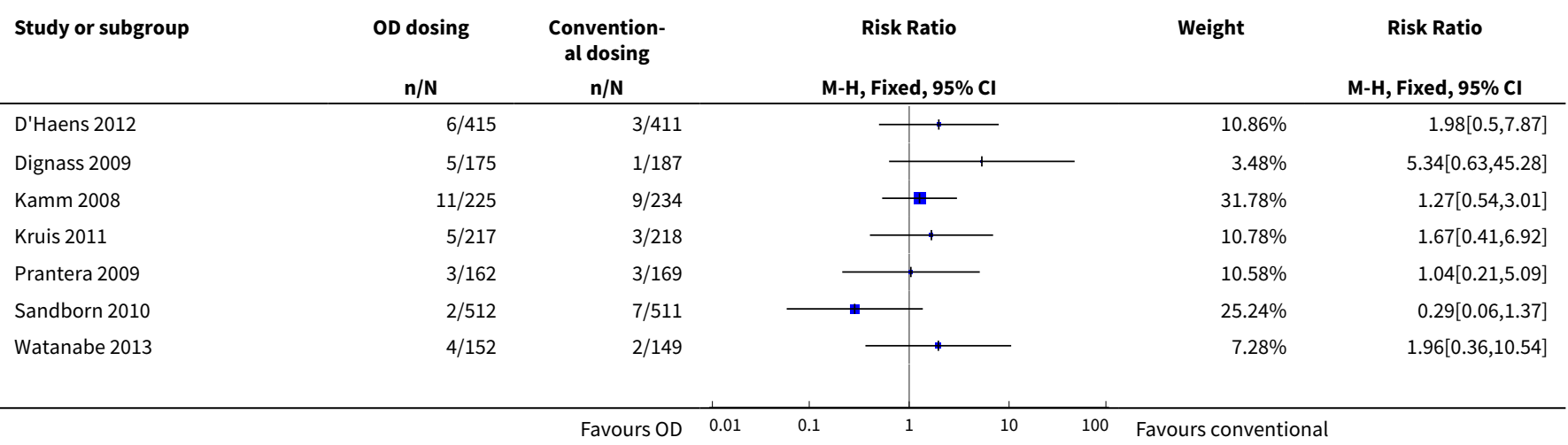




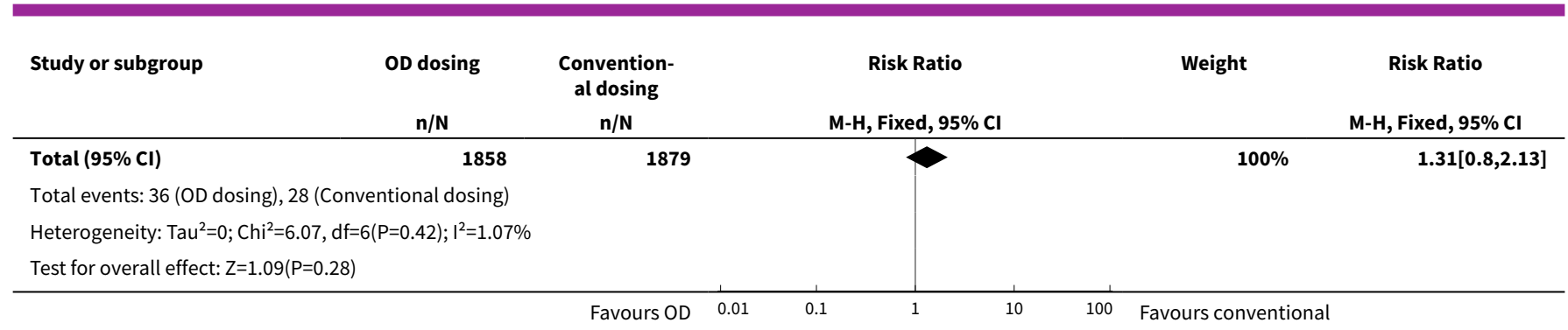

\section{Analysis 3.7. Comparison 3 Once daily versus conventional dosing, Outcome 7 Exclusion/Withdrawal after Entry (not due to relapse).}

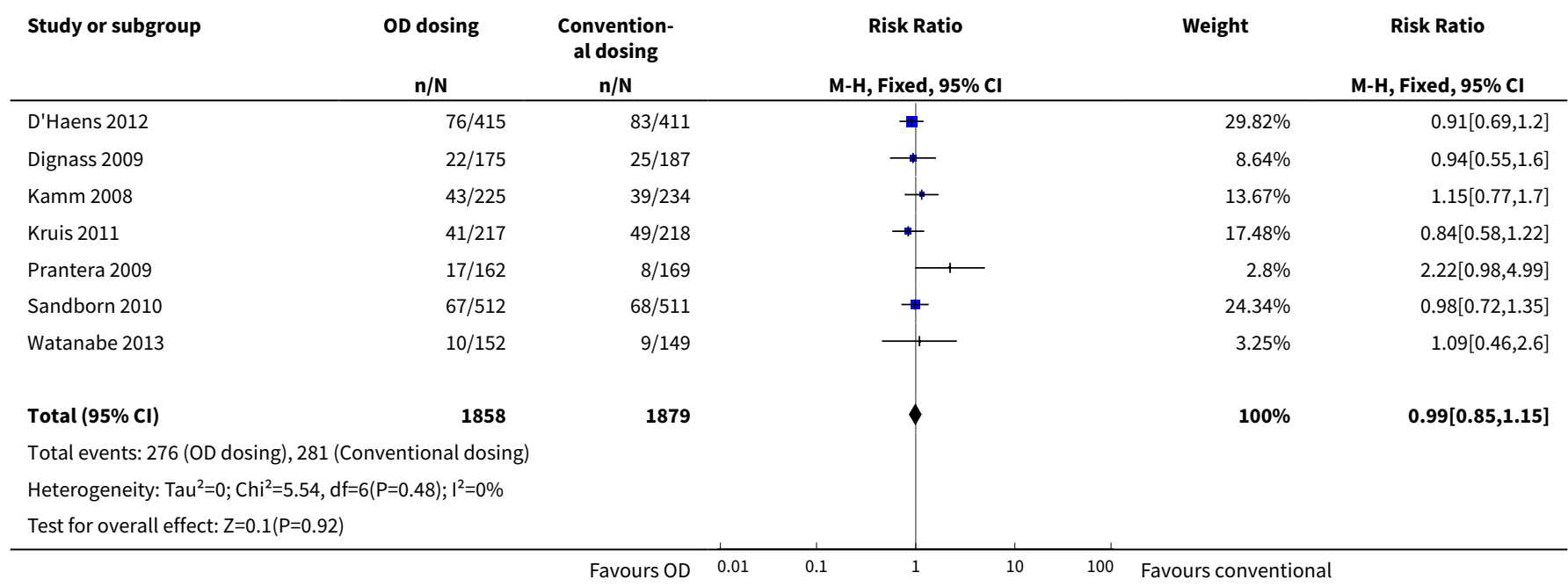

\section{Comparison 4. 5-ASA versus comparator 5-ASA}

\begin{tabular}{lllll}
\hline Outcome or subgroup title & $\begin{array}{l}\text { No. of } \\
\text { studies }\end{array}$ & $\begin{array}{l}\text { No. of } \\
\text { partici- } \\
\text { pants }\end{array}$ & Statistical method & Effect size \\
\hline $\begin{array}{l}1 \text { Failure to Maintain Clinical } \\
\text { or Endoscopic Remission at } \\
12 \text { months }\end{array}$ & 6 & 707 & Risk Ratio $(\mathrm{M}-\mathrm{H}$, Fixed, 95\% Cl) & $1.08[0.91,1.28]$ \\
\hline $\begin{array}{l}1.1 \text { Asacol comparator } \\
1.2 \text { Salofalk comparator }\end{array}$ & 1 & 615 & Risk Ratio (M-H, Fixed, 95\% Cl) & $1.05[0.87,1.26]$ \\
\hline $\begin{array}{l}2 \text { Development of Any Ad- } \\
\text { verse Event }\end{array}$ & 4 & 357 & Risk Ratio (M-H, Fixed, 95\% Cl) & $1.30[0.86,1.98]$ \\
\hline $\begin{array}{l}2.1 \text { Asacol comparator } \\
2.2 \text { Salofalk comparator }\end{array}$ & 1 & 265 & Risk Ratio (M-H, Fixed, 95\% Cl) & $0.94[0.83,1.07]$ \\
\hline
\end{tabular}




\begin{tabular}{lllll}
\hline Outcome or subgroup title & $\begin{array}{l}\text { No. of } \\
\text { studies }\end{array}$ & $\begin{array}{l}\text { No. of } \\
\text { partici- } \\
\text { pants }\end{array}$ & Statistical method & Effect size \\
\hline $\begin{array}{l}\text { 3 Withdrawal from Study due } \\
\text { to Adverse Event }\end{array}$ & 5 & 457 & Risk Ratio $(\mathrm{M}-\mathrm{H}$, Fixed, 95\% Cl) & $1.25[0.56,2.78]$ \\
\hline $\begin{array}{l}\text { 3.1 Asacol comparator } \\
\text { 3.2 Salofalk comparator }\end{array}$ & 1 & 365 & Risk Ratio (M-H, Fixed, 95\% Cl) & $1.64[0.61,4.42]$ \\
\hline $\begin{array}{l}\text { 4 Exclusion/Withdrawal after } \\
\text { Entry (not due to relapse) }\end{array}$ & 5 & 92 & Risk Ratio (M-H, Fixed, 95\% Cl) & $0.69[0.16,2.90]$ \\
\hline $\begin{array}{l}\text { 4.1 Asacol comparator } \\
\text { 4.2 Salofalk comparator }\end{array}$ & 4 & 457 & Risk Ratio (M-H, Fixed, 95\% Cl) & $1.23[0.90,1.70]$ \\
\hline
\end{tabular}

Analysis 4.1. Comparison 4 5-ASA versus comparator 5-ASA, Outcome 1 Failure to Maintain Clinical or Endoscopic Remission at 12 months.

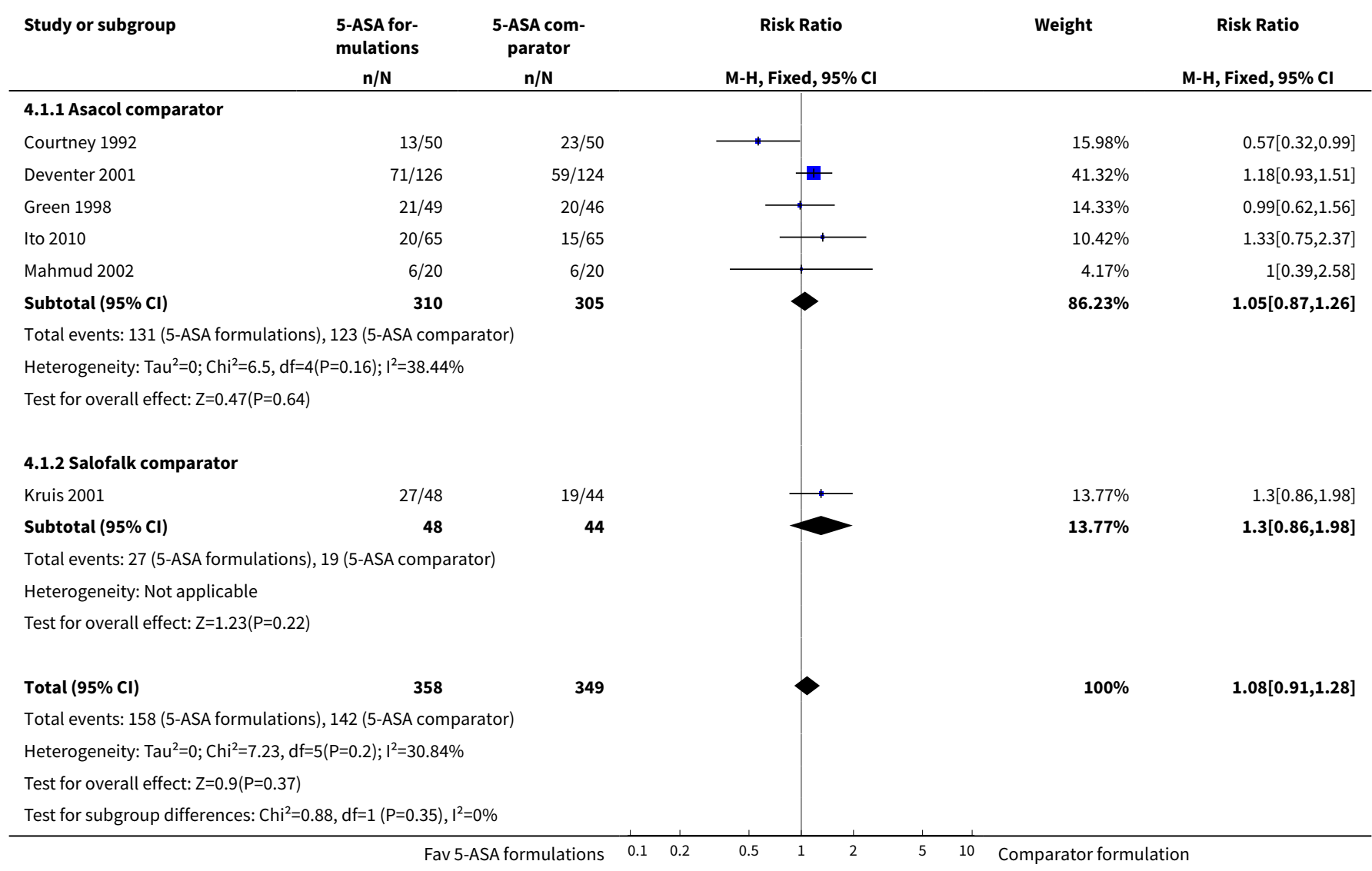


Analysis 4.2. Comparison 4 5-ASA versus comparator 5-ASA, Outcome 2 Development of Any Adverse Event.

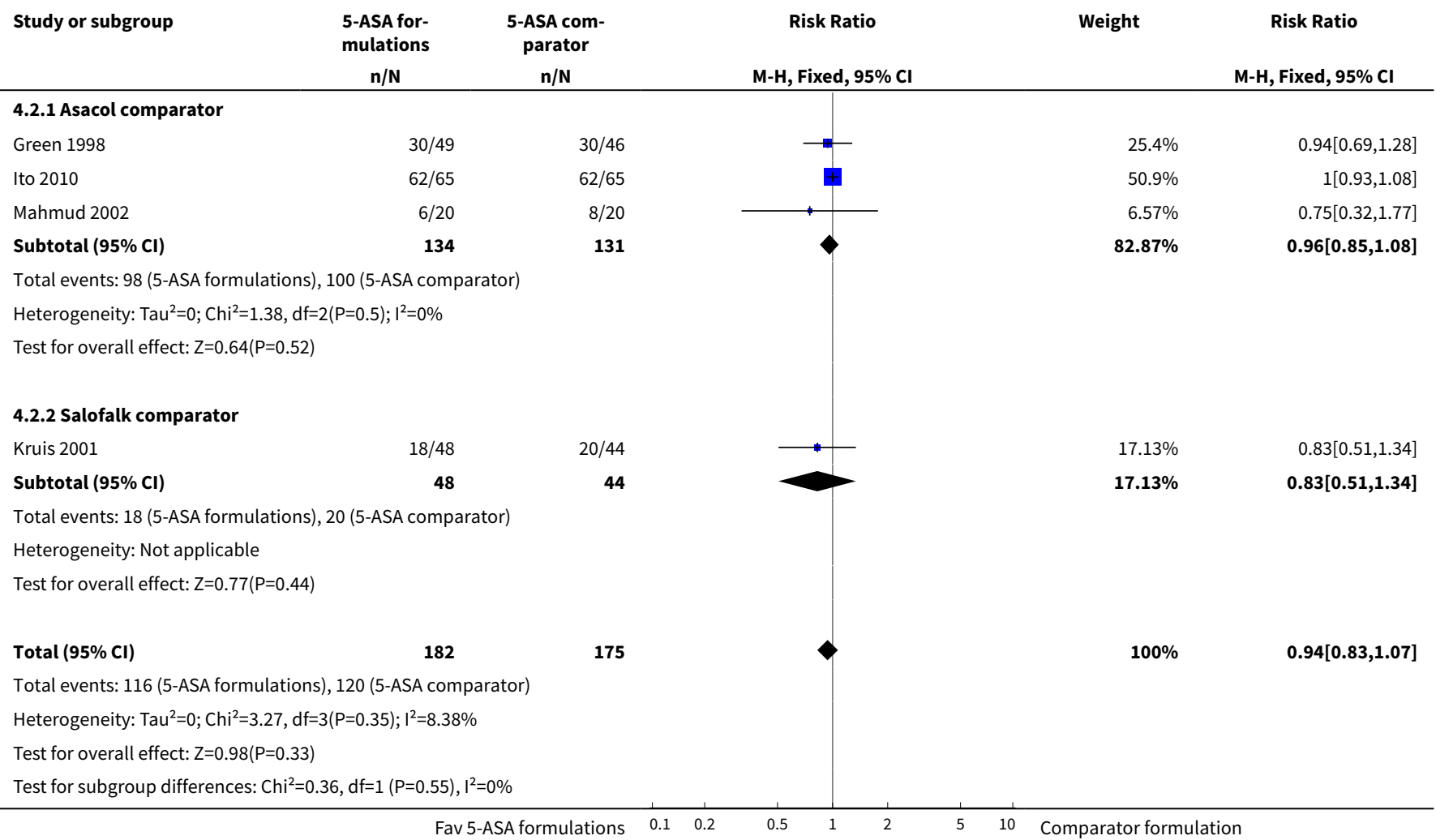

Analysis 4.3. Comparison 4 5-ASA versus comparator 5ASA, Outcome 3 Withdrawal from Study due to Adverse Event.

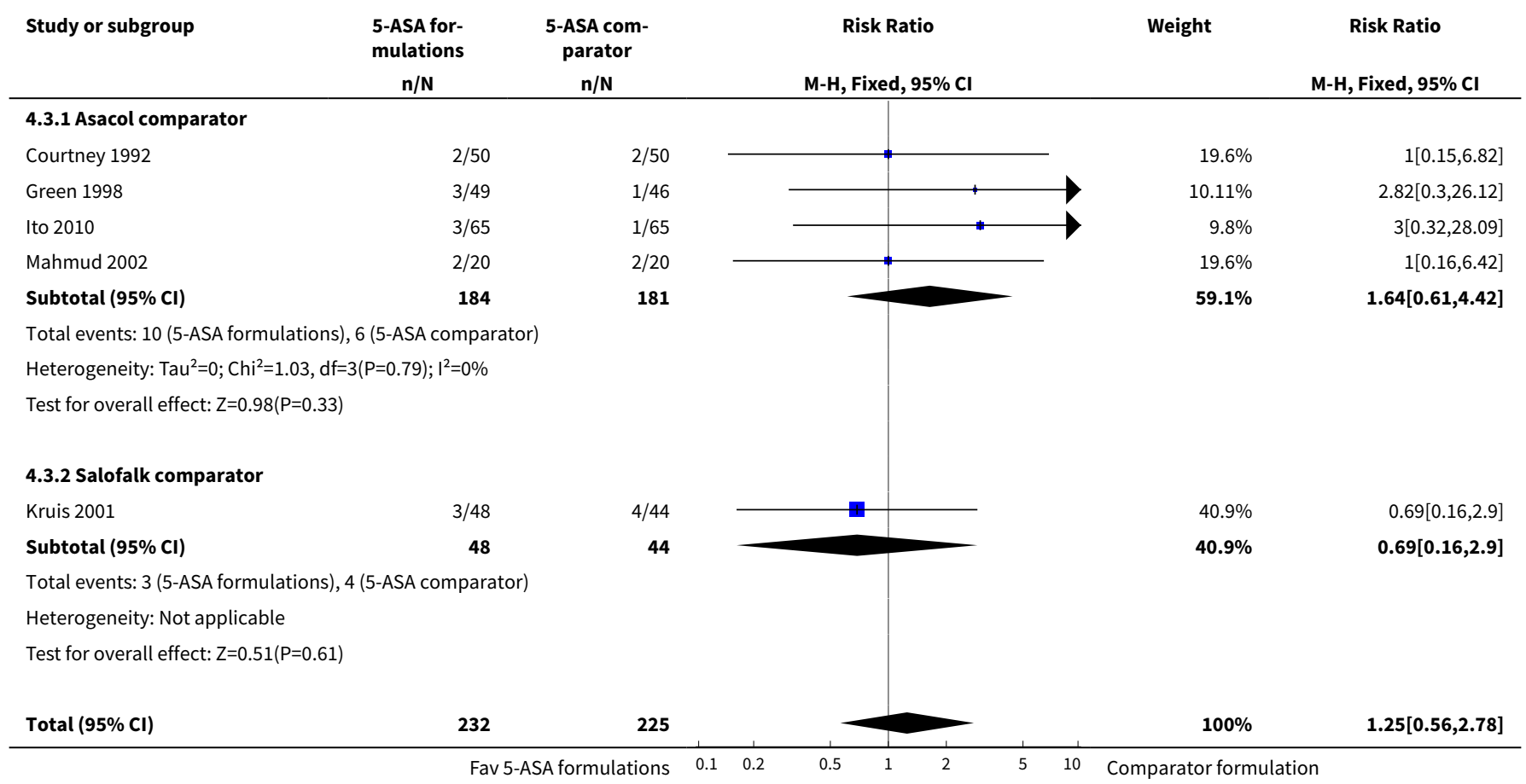




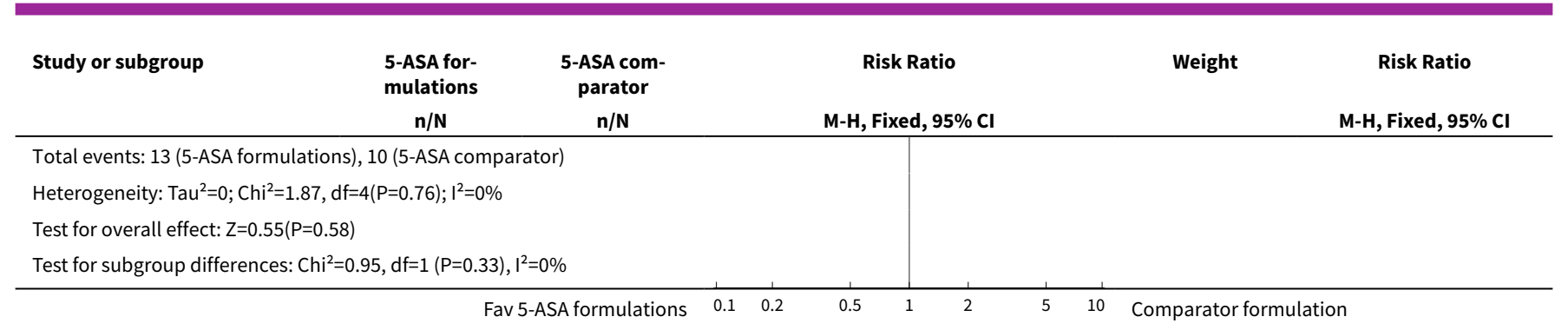

Analysis 4.4. Comparison 4 5-ASA versus comparator 5-ASA, Outcome 4 Exclusion/Withdrawal after Entry (not due to relapse).

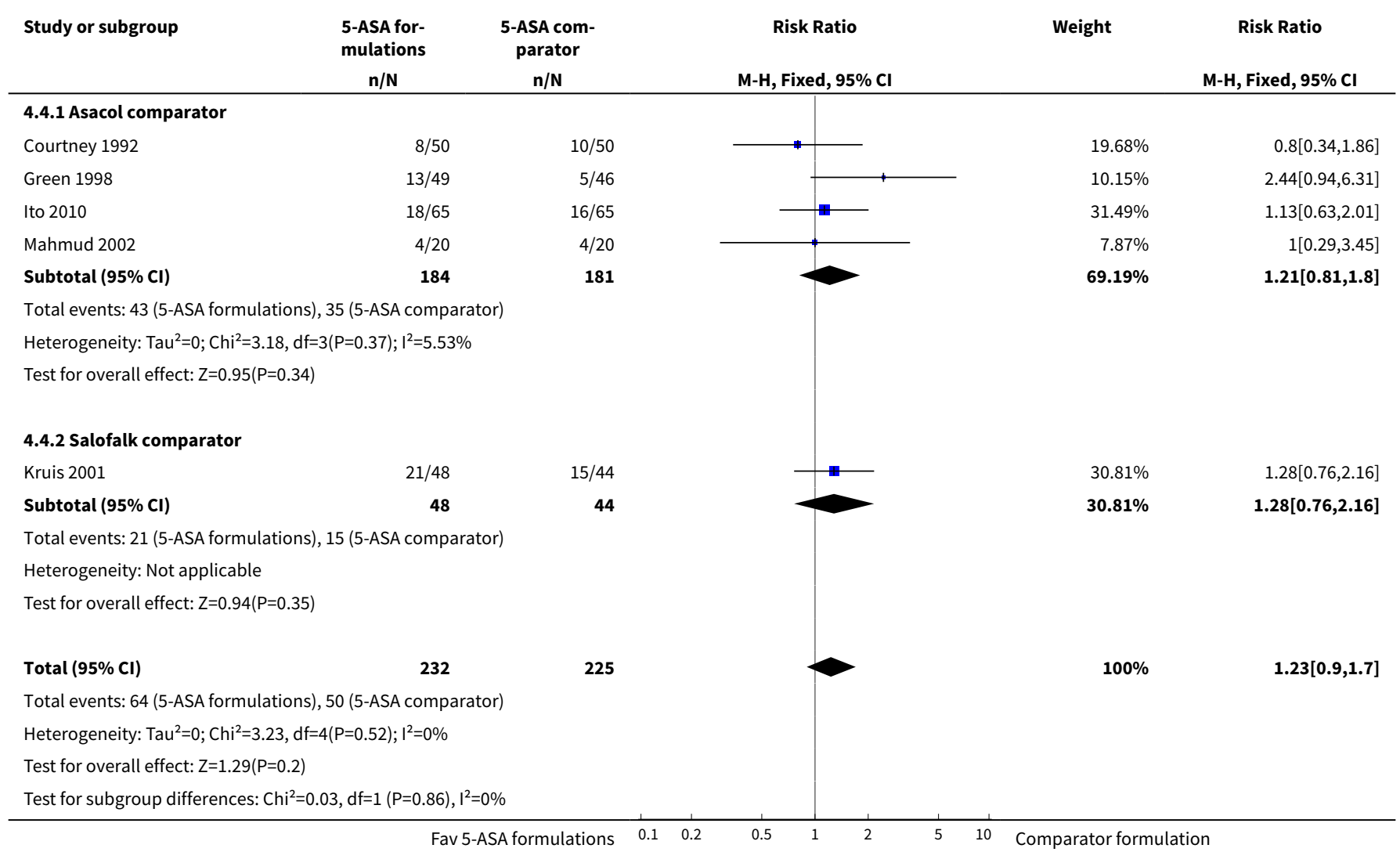

\section{Comparison 5. 5-ASA (dose ranging)}

\begin{tabular}{lllll}
\hline Outcome or subgroup title & $\begin{array}{l}\text { No. of } \\
\text { studies }\end{array}$ & $\begin{array}{l}\text { No. of } \\
\text { partici- } \\
\text { pants }\end{array}$ & Statistical method & Effect size \\
\hline $\begin{array}{l}1 \text { Failure to Maintain Clinical or } \\
\text { Endoscopic Remission }\end{array}$ & 10 & & Risk Ratio (M-H, Random, 95\% Cl) & Subtotals only \\
\hline 1.1 Asacol 4.8 g versus 2.4 g/day & 1 & 112 & Risk Ratio (M-H, Random, 95\% Cl) & $0.8[0.46,1.38]$ \\
\hline 1.2 Asacol 3.2 g versus 2 g/day & 1 & 262 & Risk Ratio (M-H, Random, 95\% Cl) & $1.07[0.83,1.37]$ \\
\hline \hline
\end{tabular}




\begin{tabular}{|c|c|c|c|c|}
\hline Outcome or subgroup title & $\begin{array}{l}\text { No. of } \\
\text { studies }\end{array}$ & $\begin{array}{l}\text { No. of } \\
\text { partici- } \\
\text { pants }\end{array}$ & Statistical method & Effect size \\
\hline 1.3 Asacol $2.4 \mathrm{~g}$ versus $1.2 \mathrm{~g} /$ day & 1 & 156 & Risk Ratio (M-H, Random, 95\% Cl) & $0.95[0.78,1.16]$ \\
\hline 1.4 Asacol $1.6 \mathrm{~g}$ versus $0.8 \mathrm{~g} /$ day & 1 & 177 & Risk Ratio (M-H, Random, 95\% Cl) & $1.01[0.78,1.32]$ \\
\hline $\begin{array}{l}1.5 \text { Balsalazide } 6.0 \text { g versus } 3.0 \\
\text { g/day }\end{array}$ & 2 & 216 & Risk Ratio (M-H, Random, 95\% Cl) & $0.76[0.21,2.79]$ \\
\hline $\begin{array}{l}\text { 1.6 Balsalazide } 4.0 \text { g versus } 2.0 \\
\text { g/day }\end{array}$ & 1 & 133 & Risk Ratio (M-H, Random, 95\% Cl) & $0.66[0.45,0.97]$ \\
\hline $\begin{array}{l}1.7 \text { Olsalazine } 2.0 \text { g versus } 1.0 \mathrm{~g} / \\
\text { day }\end{array}$ & 1 & 127 & Risk Ratio (M-H, Random, 95\% Cl) & $1.01[0.66,1.54]$ \\
\hline $\begin{array}{l}\text { 1.8 Salofalk granules } 3 \mathrm{~g} \text { versus } \\
1.5 \mathrm{~g} \text { OD }\end{array}$ & 1 & 429 & Risk Ratio (M-H, Random, 95\% Cl) & $0.65[0.49,0.86]$ \\
\hline $\begin{array}{l}1.9 \text { Pentasa } 3.0 \mathrm{~g} \text { versus } 1.5 \mathrm{~g} / \\
\text { day }\end{array}$ & 1 & 169 & Risk Ratio (M-H, Random, 95\% Cl) & $0.74[0.48,1.15]$ \\
\hline $\begin{array}{l}2 \text { Development of Any Adverse } \\
\text { Event }\end{array}$ & 5 & & Risk Ratio (M-H, Fixed, 95\% Cl) & Subtotals only \\
\hline 2.1 Asacol $2.4 \mathrm{~g}$ versus $1.2 \mathrm{~g} /$ day & 1 & 156 & Risk Ratio (M-H, Fixed, 95\% Cl) & $2.85[0.12,68.95]$ \\
\hline 2.2 Asacol $1.6 \mathrm{~g}$ versus $0.8 \mathrm{~g} /$ day & 1 & 177 & Risk Ratio (M-H, Fixed, 95\% Cl) & $1.86[1.18,2.95]$ \\
\hline $\begin{array}{l}2.3 \text { Balsalazide } 6.0 \text { g versus } 3.0 \\
\text { g/day }\end{array}$ & 1 & 88 & Risk Ratio (M-H, Fixed, 95\% Cl) & $1.4[0.88,2.24]$ \\
\hline $\begin{array}{l}2.4 \text { Olsalazine } 2.0 \mathrm{~g} \text { versus } 1.0 \mathrm{~g} / \\
\text { day }\end{array}$ & 1 & 127 & Risk Ratio (M-H, Fixed, 95\% Cl) & $1.37[0.94,1.99]$ \\
\hline $\begin{array}{l}2.5 \text { Salofalk granules } 3 \mathrm{~g} \text { versus } \\
1.5 \mathrm{~g} \text { OD }\end{array}$ & 1 & 429 & Risk Ratio (M-H, Fixed, 95\% Cl) & $0.74[0.61,0.91]$ \\
\hline $\begin{array}{l}3 \text { Withdrawal from Study due to } \\
\text { Adverse Event }\end{array}$ & 7 & & Risk Ratio (M-H, Fixed, 95\% Cl) & Subtotals only \\
\hline 3.1 Asacol $2.4 \mathrm{~g}$ versus $1.2 \mathrm{~g} /$ day & 1 & 156 & Risk Ratio (M-H, Fixed, 95\% Cl) & $2.85[0.12,68.95]$ \\
\hline 3.2 Asacol $1.6 \mathrm{~g}$ versus $0.8 \mathrm{~g} /$ day & 1 & 177 & Risk Ratio (M-H, Fixed, 95\% Cl) & $0.34[0.04,3.25]$ \\
\hline $\begin{array}{l}3.3 \text { Balsalazide } 6.0 \text { g versus } 3.0 \\
\text { g/day }\end{array}$ & 2 & 196 & Risk Ratio (M-H, Fixed, 95\% Cl) & $0.59[0.21,1.70]$ \\
\hline $\begin{array}{l}\text { 3.4 Balsalazide } 4.0 \text { g versus } 2.0 \\
\text { g/day }\end{array}$ & 1 & 133 & Risk Ratio (M-H, Fixed, 95\% Cl) & $1.43[0.54,3.80]$ \\
\hline $\begin{array}{l}3.5 \text { Salofalk granules } 3 \mathrm{~g} \text { versus } \\
1.5 \mathrm{~g} \text { OD }\end{array}$ & 1 & 429 & Risk Ratio (M-H, Fixed, 95\% Cl) & $0.98[0.29,3.33]$ \\
\hline $\begin{array}{l}\text { 3.6 Pentasa } 3.0 \mathrm{~g} \text { versus } 1.5 \mathrm{~g} / \\
\text { day }\end{array}$ & 1 & 169 & Risk Ratio (M-H, Fixed, 95\% Cl) & $1.06[0.07,16.69]$ \\
\hline
\end{tabular}




\begin{tabular}{|c|c|c|c|c|}
\hline Outcome or subgroup title & $\begin{array}{l}\text { No. of } \\
\text { studies }\end{array}$ & $\begin{array}{l}\text { No. of } \\
\text { partici- } \\
\text { pants }\end{array}$ & Statistical method & Effect size \\
\hline $\begin{array}{l}4 \text { Exculsion/Withdrawal after } \\
\text { Entry (not due to relapse) }\end{array}$ & 8 & & Risk Ratio (M-H, Fixed, 95\% Cl) & Subtotals only \\
\hline 4.1 Asacol $2.4 \mathrm{~g}$ versus $1.2 \mathrm{~g} / \mathrm{day}$ & 1 & 156 & Risk Ratio (M-H, Fixed, 95\% Cl) & $0.95[0.38,2.40]$ \\
\hline 4.2 Asacol $1.6 \mathrm{~g}$ versus $0.8 \mathrm{~g} / \mathrm{day}$ & 1 & 177 & Risk Ratio (M-H, Fixed, 95\% Cl) & $1.23[0.80,1.90]$ \\
\hline $\begin{array}{l}\text { 4.3 Balsalazide } 6.0 \text { g versus } 3.0 \\
\text { g/day }\end{array}$ & 2 & 196 & Risk Ratio (M-H, Fixed, 95\% Cl) & $0.47[0.26,0.84]$ \\
\hline $\begin{array}{l}\text { 4.4 Balsalazide } 4.0 \text { g versus } 2.0 \\
\text { g/day }\end{array}$ & 1 & 133 & Risk Ratio (M-H, Fixed, 95\% Cl) & $1.27[0.77,2.12]$ \\
\hline $\begin{array}{l}4.5 \text { Olsalazine } 2.0 \text { g versus } 1.0 \mathrm{~g} / \\
\text { day }\end{array}$ & 1 & 127 & Risk Ratio (M-H, Fixed, 95\% Cl) & $1.75[0.83,3.70]$ \\
\hline $\begin{array}{l}\text { 4.6 Salofalk granules } 3 \mathrm{~g} \text { versus } \\
\text { 1.5 g OD }\end{array}$ & 1 & 429 & Risk Ratio (M-H, Fixed, 95\% Cl) & $0.66[0.46,0.93]$ \\
\hline $\begin{array}{l}\text { 4.7 Pentasa } 3.0 \mathrm{~g} \text { versus } 1.5 \mathrm{~g} / \\
\text { day }\end{array}$ & 1 & 169 & Risk Ratio (M-H, Fixed, 95\% Cl) & $0.83[0.44,1.55]$ \\
\hline
\end{tabular}

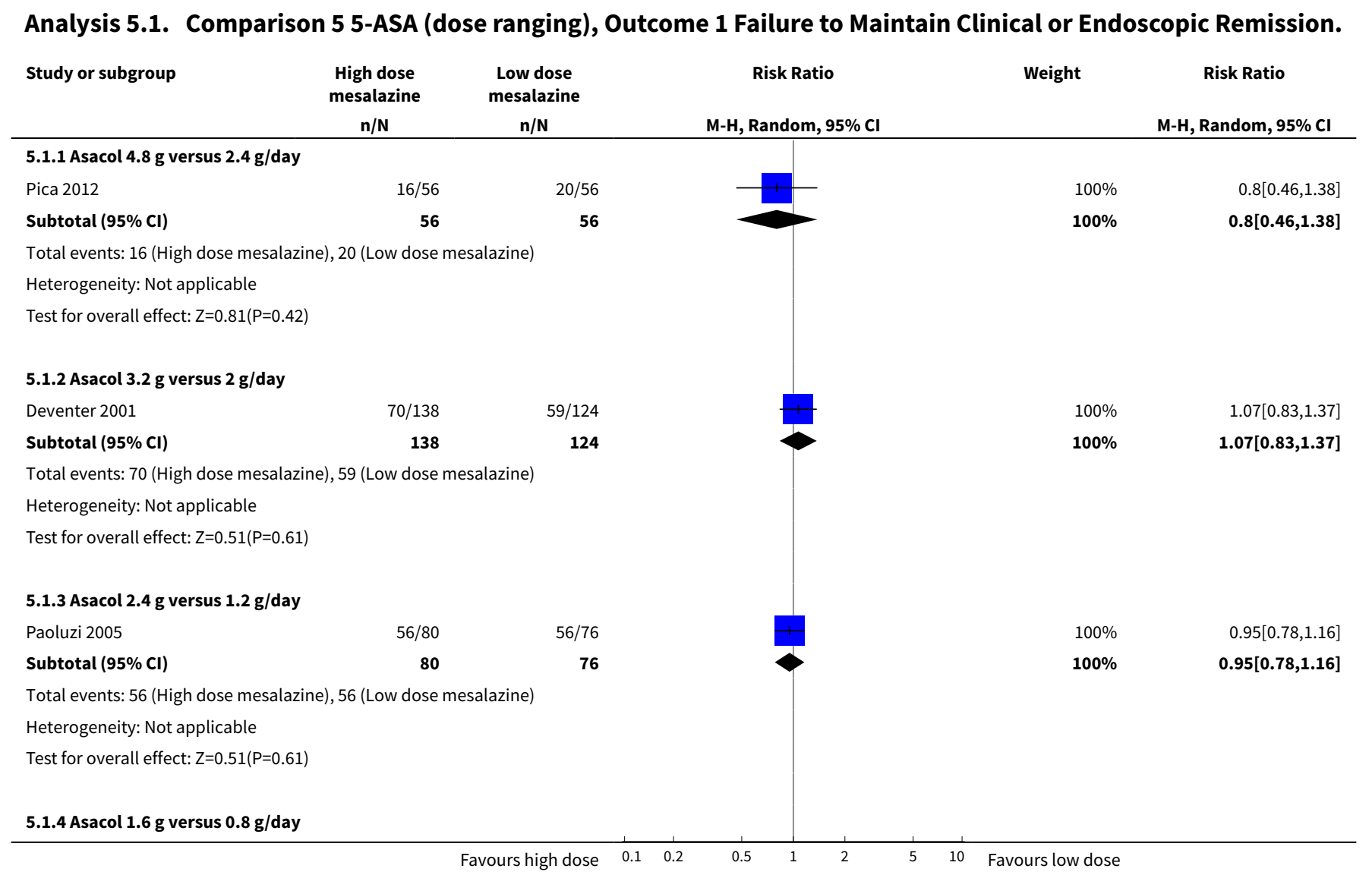




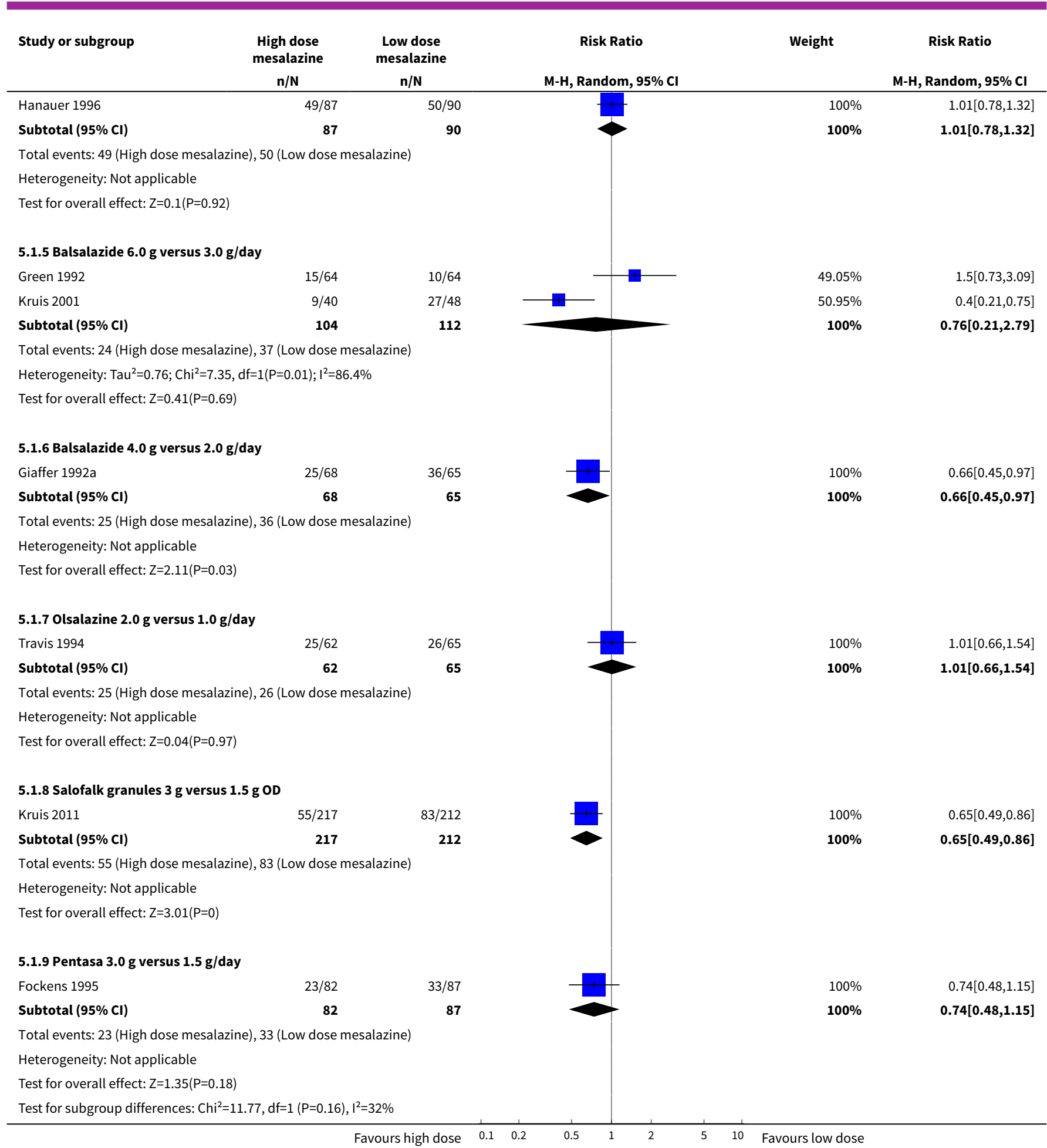


Analysis 5.2. Comparison 5 5-ASA (dose ranging), Outcome 2 Development of Any Adverse Event.

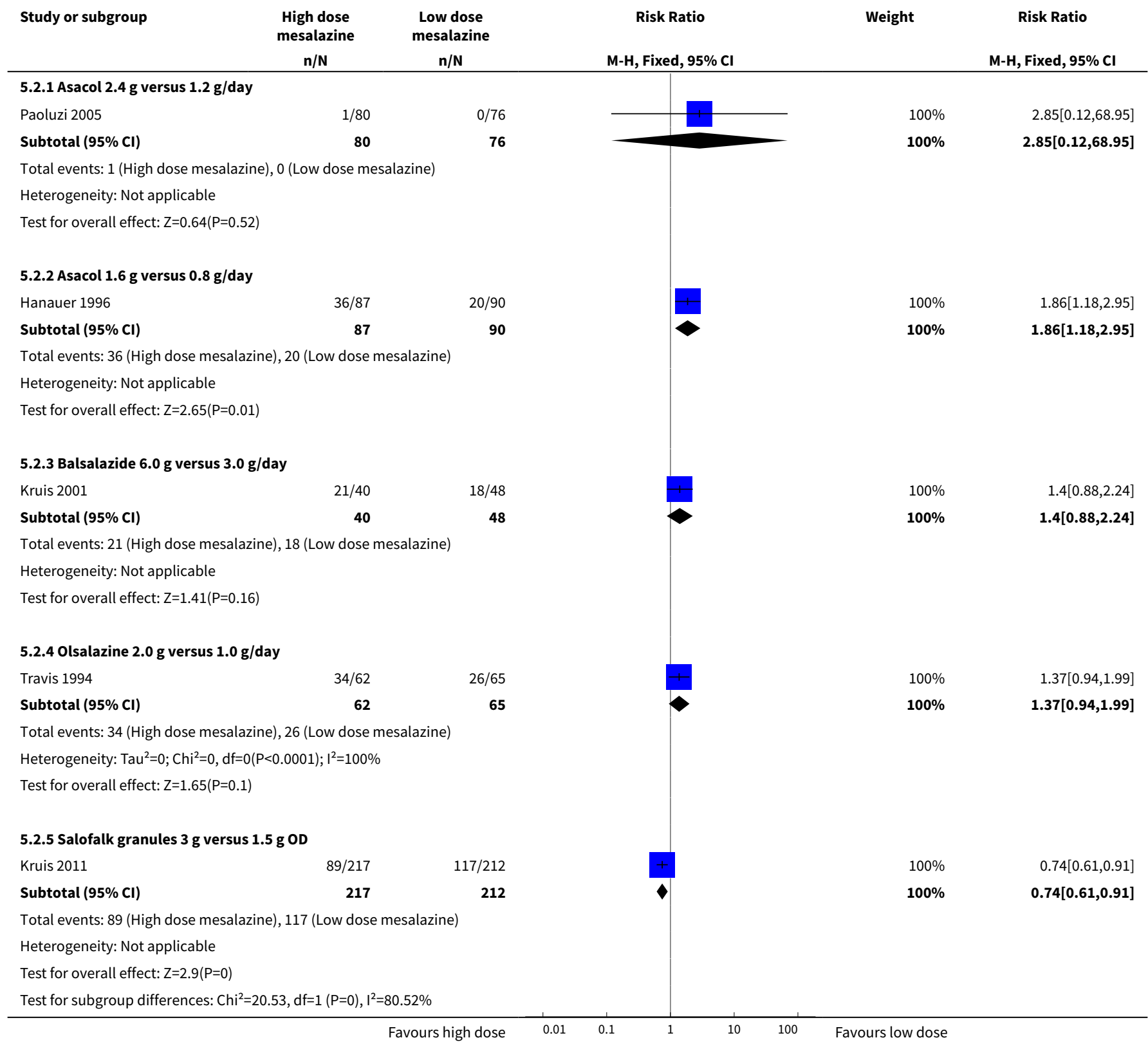

Analysis 5.3. Comparison 5 5-ASA (dose ranging), Outcome 3 Withdrawal from Study due to Adverse Event.

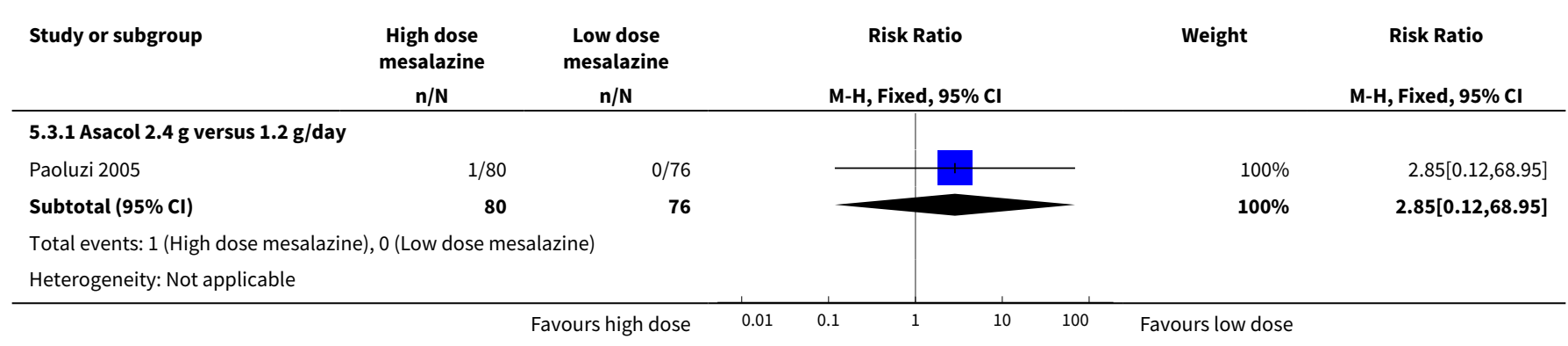




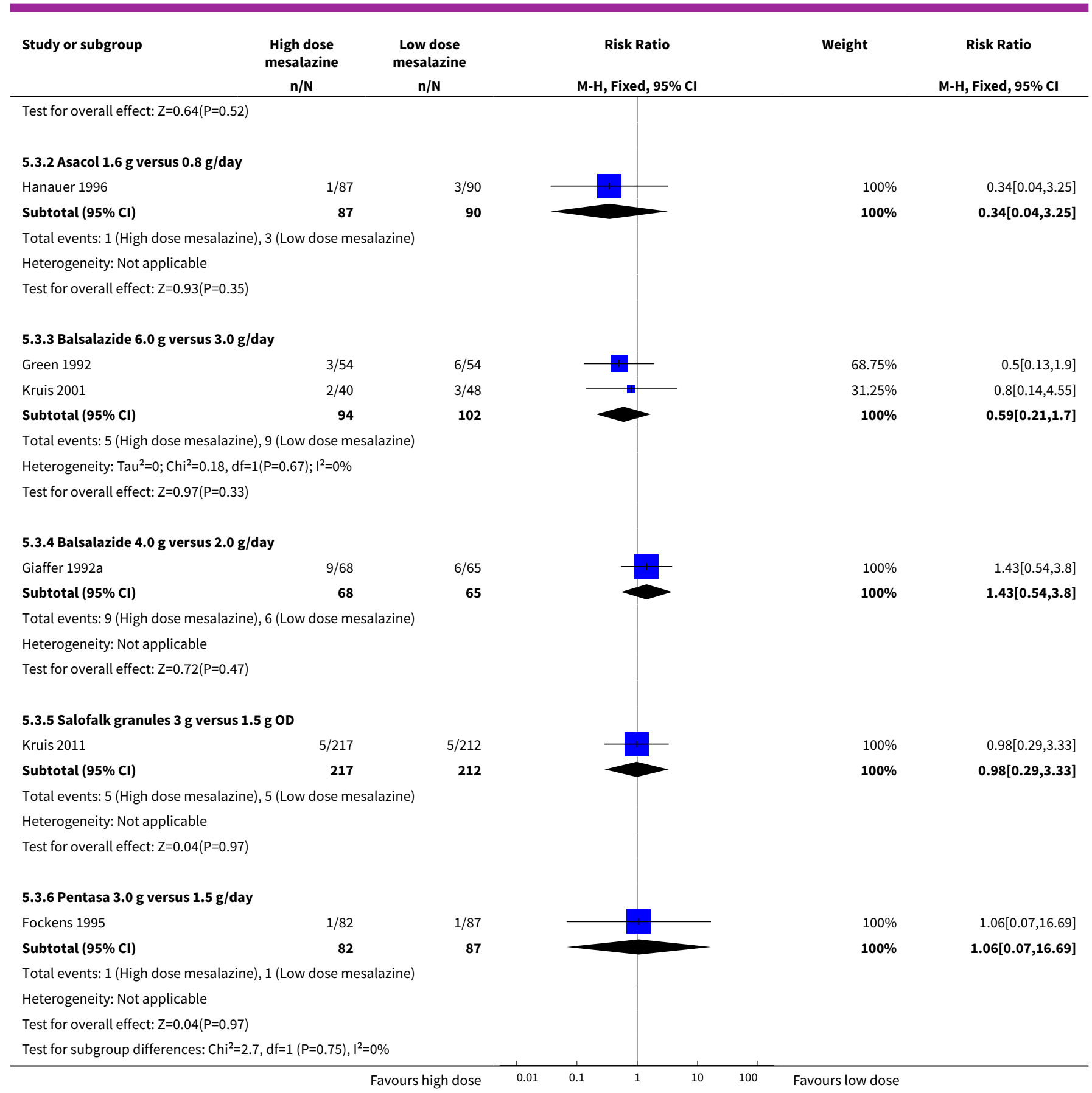

Analysis 5.4. Comparison 5 5-ASA (dose ranging), Outcome 4 Exculsion/Withdrawal after Entry (not due to relapse).

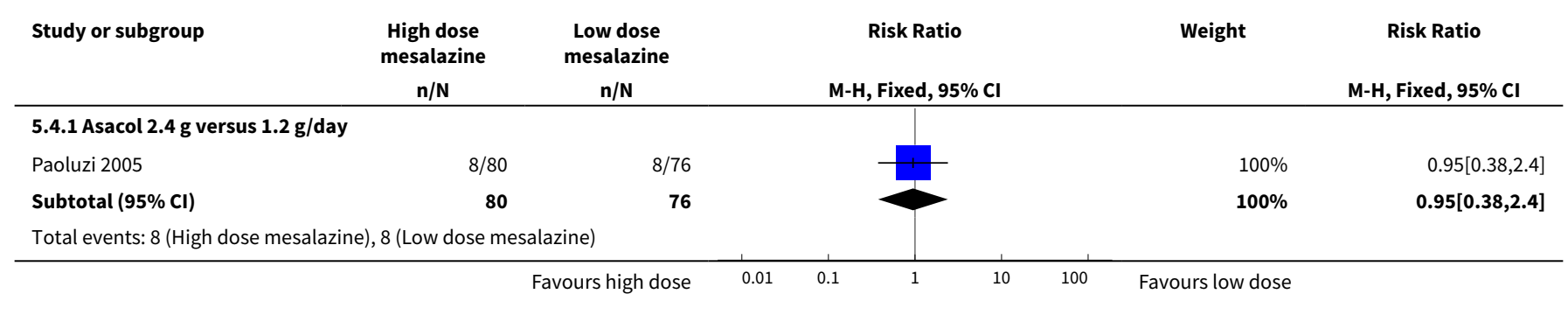




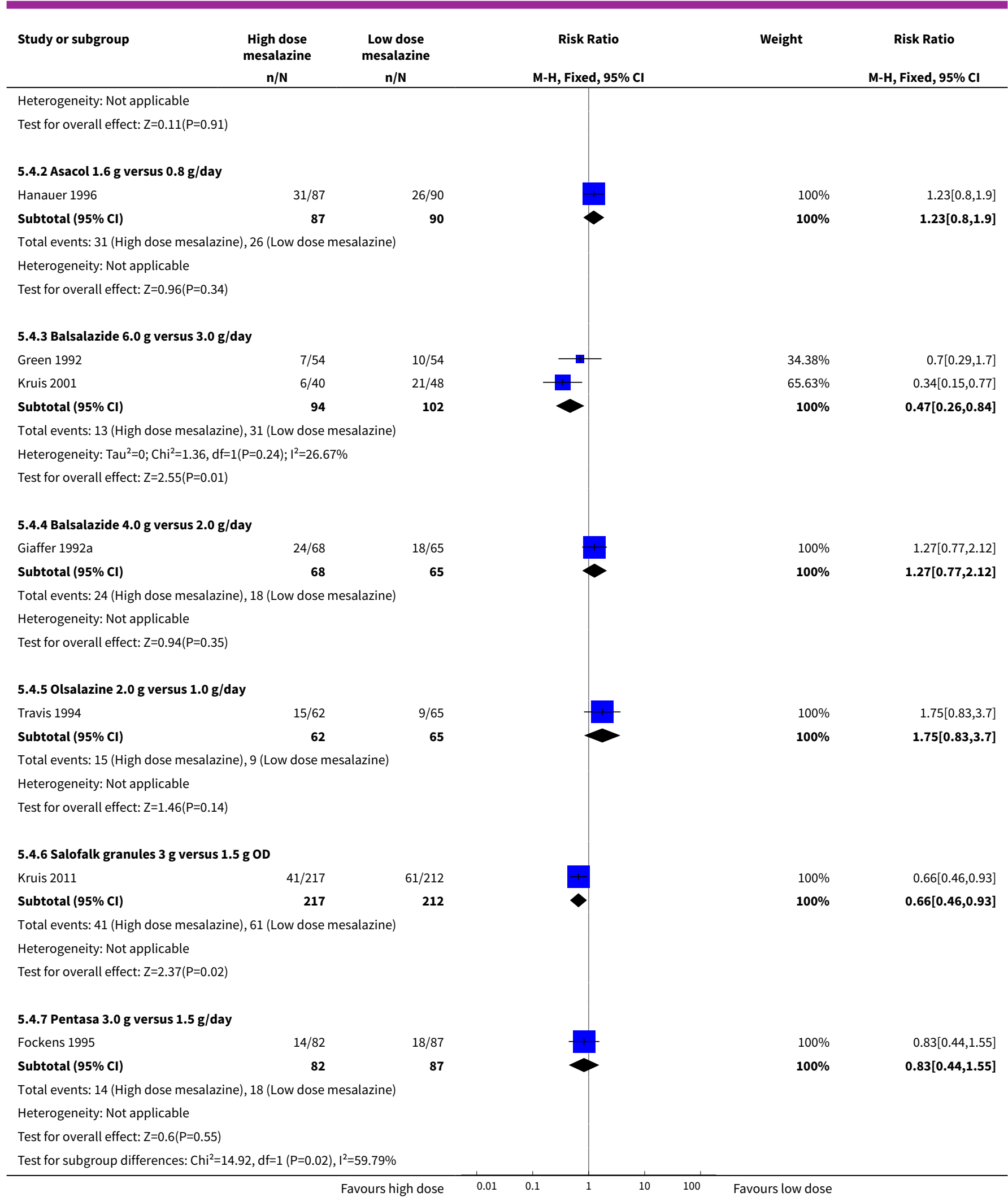




\section{APPENDICES}

\section{Appendix 1. Search strategies}

\section{MEDLINE Search Strategy:}

1. random\$.tw.

2. factorial\$.tw.

3. (crossover\$ or cross over\$ or cross-over\$).tw.

4. placebo\$.tw.

5. single blind.mp.

6. double blind.mp.

7. triple blind.mp.

8. (singl\$ adj blind\$).tw.

9. (double\$ adj blind\$).tw.

10. (tripl\$ adj blind\$).tw.

11. assign\$.tw.

12. allocat\$.tw.

13. crossover procedure/

14. double blind procedure/

15. single blind procedure/

16. triple blind procedure/

17. randomized controlled trial/

18. or $/ 1-17$

19. (exp animal/ or animal.hw. or nonhuman/) not (exp human/ or human cell/ or (human or humans).ti.)

20. 18 not 19

21. (colitis and ulcerat $\left.{ }^{\star}\right) \cdot \mathrm{mp}$.

22. ulcerative colitis.mp. or exp ulcerative colitis/

23. (inflammatory bowel disease* or IBD).mp.

24. 21 or 22 or 23

25. 20 and 24

26 5-aminosalicylic acid.mp. or exp Mesalamine/

27. Mesalazine.mp. or exp Mesalamine/

28. Sulfasalazine.mp. or exp Sulfasalazine/

29. sulphasalazine.mp. or exp Sulfasalazine/

30.26 or 27 or 28 or 29

8. 25 and 30

\section{EMBASE Search Strategy:}

Oral 5-aminosalicylic acid for maintenance of remission in ulcerative colitis (Review) 
1. random\$.tw.

2. factorial\$.tw.

3. (crossover\$ or cross over\$ or cross-over\$).tw.

4. placebo\$.tw.

5. single blind.mp.

6. double blind.mp.

7. triple blind.mp.

8. (singl\$ adj blind\$).tw.

9. (double\$ adj blind\$).tw.

10. (tripl\$ adj blind\$).tw.

11. assign\$.tw.

12. allocat\$.tw.

13. crossover procedure/

14. double blind procedure/

15. single blind procedure/

16. triple blind procedure/

17. randomized controlled trial/

18. or/1-17

19. (exp animal/ or animal.hw. or nonhuman/) not (exp human/ or human cell/ or (human or humans).ti.)

20. 18 not 19

21. (colitis and ulcerat $\left.{ }^{\star}\right) \cdot \mathrm{mp}$.

22. ulcerative colitis.mp. or exp ulcerative colitis/

23. (inflammatory bowel disease* or IBD).mp.

24. 21 or 22 or 23

25. 20 and 24

265-aminosalicylic acid.mp. or exp Mesalamine/

27. Mesalazine.mp. or exp Mesalamine/

28. Sulfasalazine.mp. or exp Sulfasalazine/

29. sulphasalazine.mp. or exp Sulfasalazine/

30.26 or 27 or 28 or 29

8. 25 and 30

\section{Cochrane Library Search Strategy:}

1. MeSH descriptor: [Colitis, Ulcerative] explode all trees

2. colitis

3. \#1 or \#2

Oral 5-aminosalicylic acid for maintenance of remission in ulcerative colitis (Review) Copyright $\odot 2016$ The Cochrane Collaboration. Published by John Wiley \& Sons, Ltd. 
4. 5-ASA

5. 5-aminosalicylic acid

6. Mesalamine

7. Sulfasalazine

8. Salazosulfapyridine

9. Sulphasalazine

10. \#4 or \#5 or \#6 or \#7 or \#8 or \#9

11. \#3 and \#10

Cochrane IBD Specialized Register:

1. 5-ASA (ab/ti)

2. 5-Amino* (ab/ti)

3. Mesala* (ab/ti)

4. Sulfa* (ab/ti)

5. Sulpha* (ab/ti)

6. 1 or 2 or 3 or 4 or 5

7. Colitis (ab/ti)

8. 6 and 7

WHAT'S NEW

\begin{tabular}{lll}
\hline Date & Event & Description \\
\hline 9 July 2015 & $\begin{array}{l}\text { New citation required but conclusions } \\
\text { have not changed }\end{array}$ & Updated review with new authors \\
\hline 9 July 2015 & New search has been performed & $\begin{array}{l}\text { A new literature search was conducted on 9 July 2015. New stud- } \\
\text { ies added }\end{array}$ \\
\hline
\end{tabular}

\section{DECLARATIONS OF INTEREST}

Yongjun Wang: None known

Claire E Parker: None known

Brian G Feagan has received fees from Abbott/AbbVie, Amgen, Astra Zeneca, Avaxia Biologics Inc., Bristol-Myers Squibb, Celgene, Centocor Inc., Elan/Biogen, Ferring, JnJ/Janssen, Merck, Nestles, Novartis, Novonordisk, Pfizer, Prometheus Laboratories, Protagonist, Salix Pharma, Takeda, Teva, TiGenix, Tillotts Pharma AG and UCB Pharma for Scientific Advisory Board membership; fees from Abbott/ AbbVie, Actogenix, Akros, Albireo Pharma, Amgen, Astra Zeneca, Avaxia Biologics Inc., Avir Pharma, Axcan, Baxter Healthcare Corp., Biogen Idec, Boehringer-Ingelheim, Bristol-Myers Squibb, Calypso Biotech, Celgene, Elan/Biogen, EnGene, Ferring Pharma, Roche/Genentech, GiCare Pharma, Gilead, Given Imaging Inc., GSK, Ironwood Pharma, Janssen Biotech (Centocor), JnJ/Janssen, Kyowa Kakko Kirin Co Ltd., Lexicon, Lilly, Lycera BioTech, Merck, Mesoblast Pharma, Millennium, Nektar, Nestles, Novonordisk, Pfizer, Prometheus Therapeutics and Diagnostics, Protagonist, Receptos, Salix Pharma, Serono, Shire, Sigmoid Pharma, Synergy Pharma Inc., Takeda, Teva Pharma, TiGenix, Tillotts, UCB Pharma, Vertex Pharma, VHsquared Ltd., Warner-Chilcott, Wyeth, Zealand, and Zyngenia for consultancy; payment for lectures from Abbott/AbbVie, JnJ/Janssen, Takeda, Warner-Chilcott, UCB Pharma; his institution has received grants/grants pending from Abbott/ AbbVie, Amgen, Astra Zeneca, Bristol-Myers Squibb (BMS), Janssen Biotech (Centocor), JnJ/Janssen, Roche/Genentech, Millennium, Pfizer, Receptos, Santarus, Sanofi, Tillotts, and UCB Pharma 
John K MacDonald: None known

\section{SOURCES OF SUPPORT}

\section{Internal sources}

- University of Calgary, Calgary, Alberta, Canada.

The University of Calgary provided support for the original version of this review which was published in 1997 . The current version of the review was not supported by any internal sources.

\section{External sources}

- Searle Mucosal Defense Unit, Oakville, Ontario, Canada.

Searle provided support for the original version of this review which was published in 1997. The current version of the review was not supported by any external sources.

\section{NDEX TERMS}

\section{Medical Subject Headings (MeSH)}

Administration, Oral; Aminosalicylic Acids [*administration \& dosage]; Anti-Inflammatory Agents, Non-Steroidal [ ${ }^{*}$ administration \& dosage]; Colitis, Ulcerative [ ${ }^{\star}$ drug therapy] [prevention \& control]; Maintenance Chemotherapy [ ${ }^{\star}$ methods]; Medication Adherence [statistics \& numerical data]; Mesalamine [ ${ }^{*}$ administration \& dosage]; Randomized Controlled Trials as Topic; Recurrence; Remission Induction [methods]; Sulfasalazine [administration \& dosage]

\section{MeSH check words}

Humans 